\title{
Stratigraphy and facies of mid-Palaeozoic successions in southern Mongolia
}

\author{
Dissertation \\ zur Erlangung des Doktorgrades \\ der Naturwissenschaften
}

\author{
vorgelegt beim Fachbereich 11 \\ der Johann Wolfgang Goethe-Universität \\ in Frankfurt am Main
}

von

Ariuntogos Munkhjargal

aus der Mongolei

Frankfurt, 2021 
vom Fachbereich 11 Geowissenschaften/Geographie der Johann Wolfgang Goethe-Universität als Dissertation angenommen.

Dekan: Prof. Dr. Georg Rümpker

Gutachter: Prof. Dr. Andreas Mulch

Goethe Universität Frankfurt/Main, Germany

Senckenberg Forschungsinstitut und Naturmuseum Frankfurt

Biodiversität und Klima Forschungszentrum,

Frankfurt am Main, Germany

Dr. Peter Königshof

Senckenberg Forschungsinstitut und Naturmuseum Frankfurt

Historische Geologie und Fazieskunde

Paläontologie und Historische Geologie

Frankfurt am Main, Germany

Datum der Disputation: 09.12.2021 


\section{Contents}

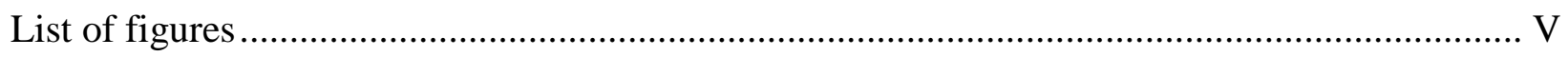

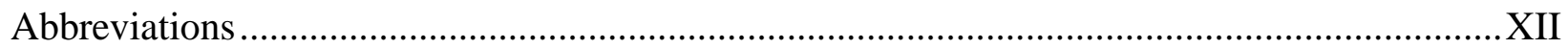

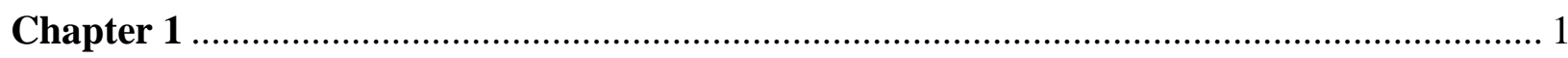

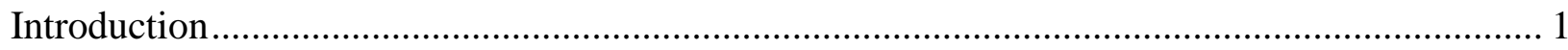

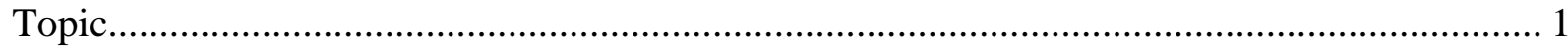

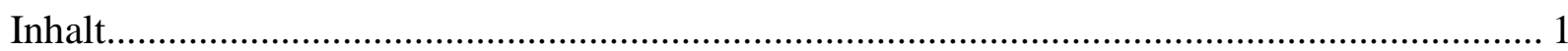

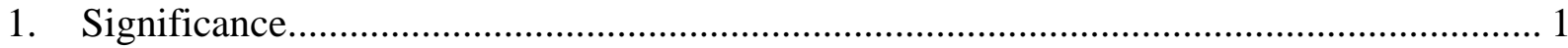

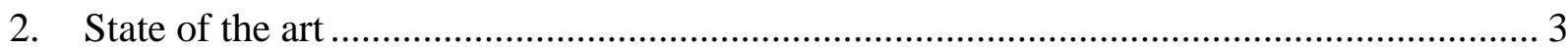

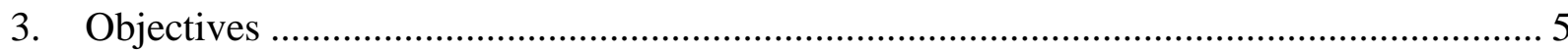

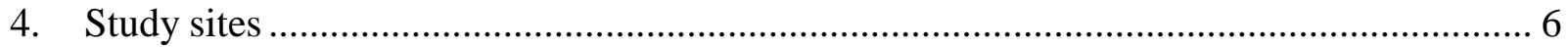

4.1. Southwestern Mongolia, Baruunhuurai Terrane, Samnuuruul Formation .................... 6

4.2. Southern Mongolia, Mandalovoo Terrane, Mushgai region ......................................... 6

5. Materials and applied methods ……………………….............................................. 7

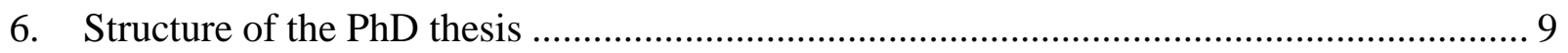

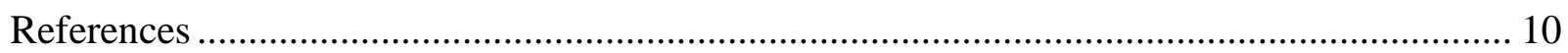

Chapter 2 - The Hushoot Shiveetiin gol section (Baruunhuurai Terrane, Mongolia): Sedimentology and facies from a Devonian island arc setting .......................................... 17

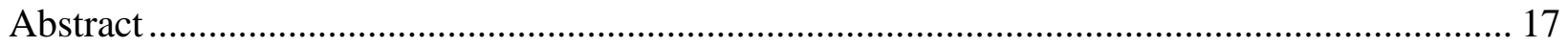

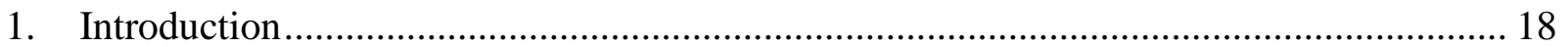

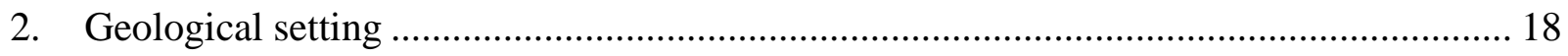

3. Materials and methods ............................................................................................... 20

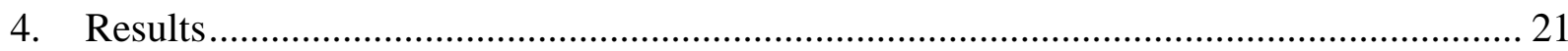

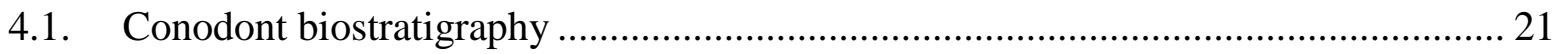

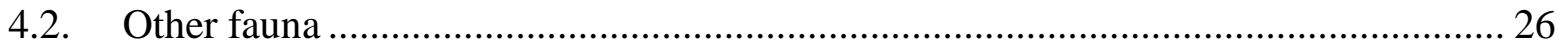

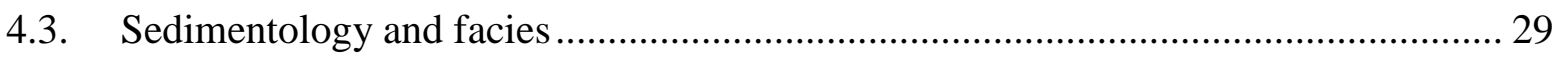

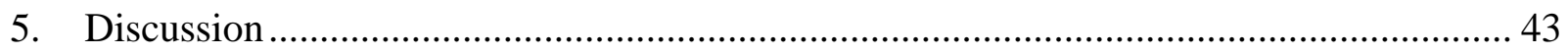

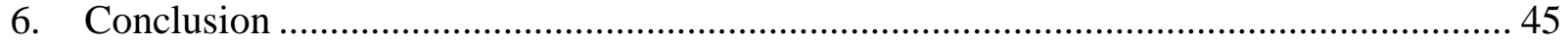

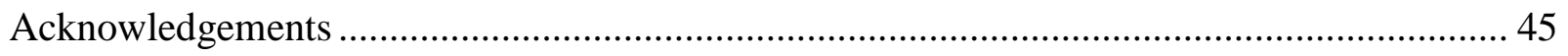

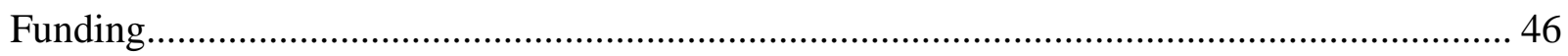

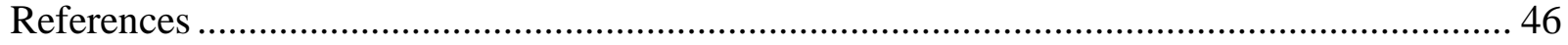


Chapter 3 - Late Devonian (Famennian) phacopid trilobites from western Mongolia ....... 58

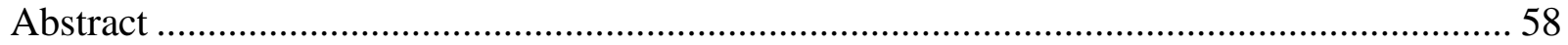

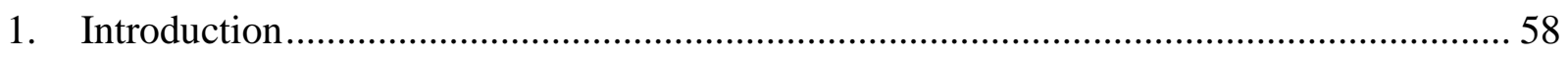

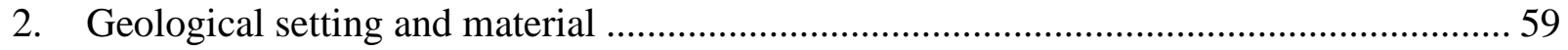

3. Systematic palaeontology (by C. Crônier) ..................................................................... 61

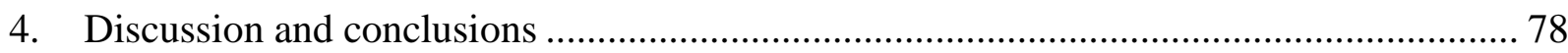

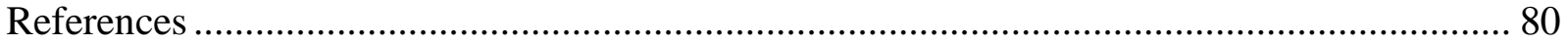

Chapter 4 - The Mandalovoo-Gurvansayhan terranes in the southern Gobi of Mongolia: new insingts from the Bayankhoshuu Ruins section ................................................ 86

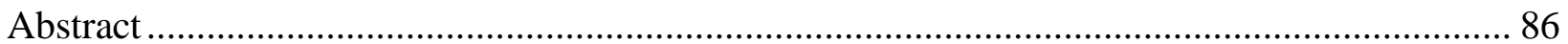

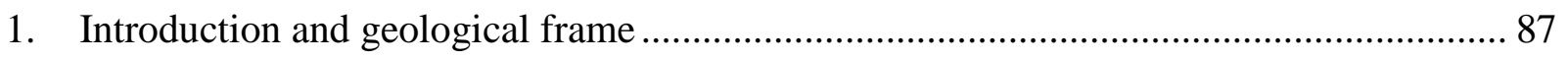

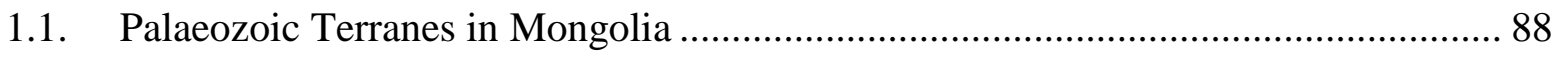

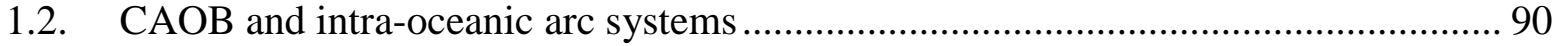

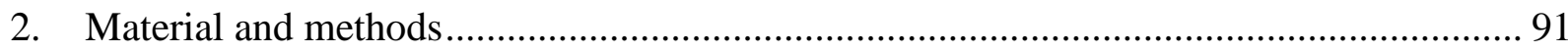

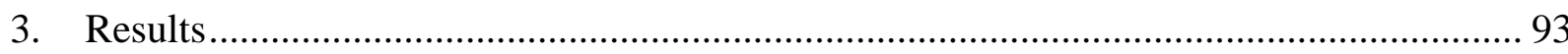

3.1. Regional geology-Bayankhoshuu Ruins area ................................................. 93

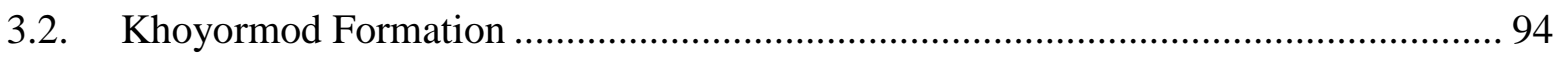

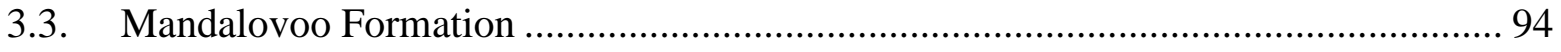

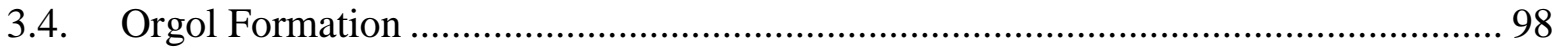

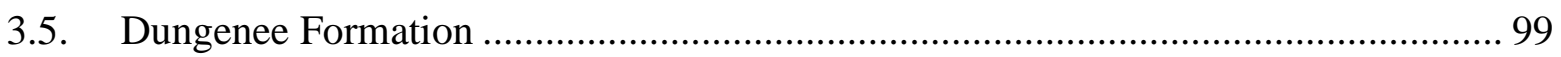

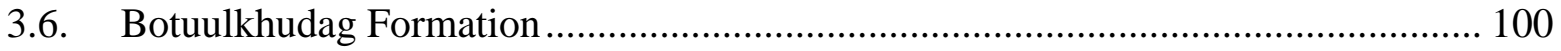

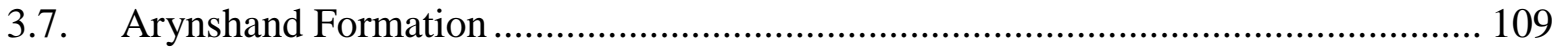

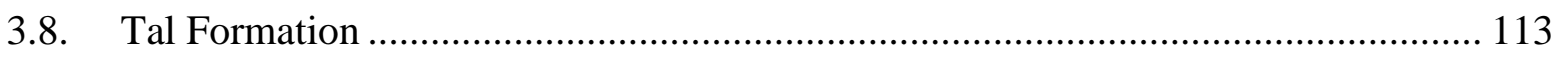

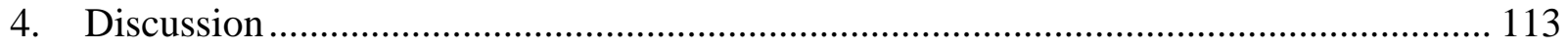

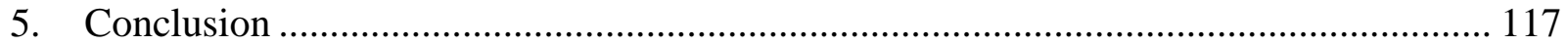

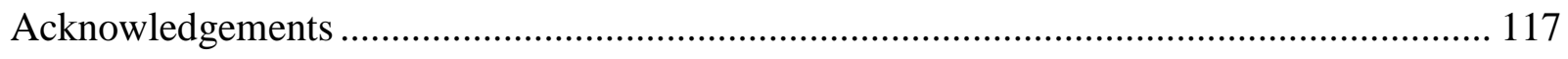

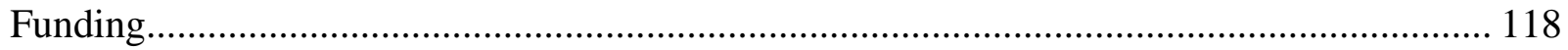

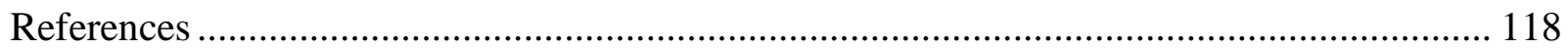

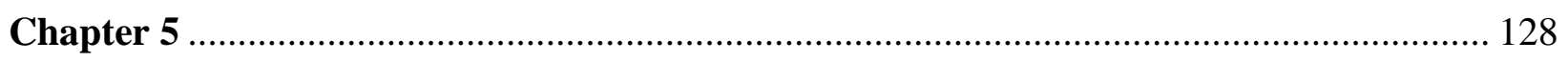

Summary (This summary also considers results of two other published papers (Roelofs et al. 2021; Waters et al. 2021) ................................................................................................ 128 


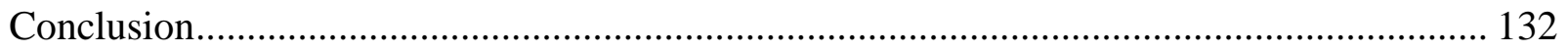

Zusammenfassung (Diese Zusammenfassung berücksichtigt auch die Ergebnisse der Publikationen Waters et al. 2021; Roelofs et al. 2021) ………….................................... 134

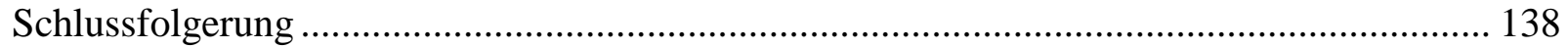

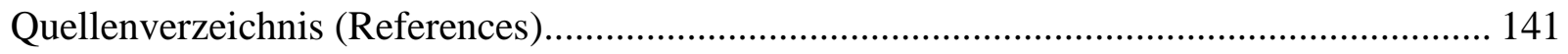




\section{List of figures}

\section{Chapter 1}

Fig. 1 Investigated sections (red asterisks) in southern and south-western Mongolia during the years 2018/2019

Fig. 2 Palaeogeographic map of the Late Devonian (base map from Blakey 2016).. 4

Fig. 3 Thin sections from Hushoot Shiveetiin gol section. Size $7.5 \times 11 \mathrm{~cm}$ .8

\section{Chapter 2}

Fig. 1 Geological map of the Hushoot Shiveetiin gol section, eastern part (A) and western part (B), based on new mapping data during fieldwork in 2018

Fig. 2 Conodont distribution chart of Famennian deposits at the Hushoot Shiveetiin gol section. Data compiled from Suttner et al. (2020) and data from fieldwork in 2018 presented herein. Zonation scheme follows Spalletta et al. (2017) 22

Fig. 3 Important conodonts from the Hushoot Shiveetiin gol section (collection numbers in brackets). 1: Ancyrognathus symmetricus, sample HS-C-W-19, oral view (MUST-RCSP-CON. 0003); 2: Ancyrognathus minjini, sample HS-C-3, oral view (MUST-RCSP-CON. 0004); 3: Ancyrognathus bifurcatus, sample HS-C-9, oral view (MUST-RCSP-CON. 0012); 4: Caenodontus sp., sample HS-C-6c (MUST-RCSP-CON. 0033); 5: Palmatolepis cf. quadrantinodosalobata (atypical morphotype) sample HS-C-6c, upper view (MUST-RCSP-CON. 0034); 6: Palmatolepis quadrantinodosalobata sample HS-CW-18, upper view (MUST-RCSP-CON. 0021); 7: Palmatolepis glabra prima M3, sample HS-C-10, upper view (MUST-RCSP-CON. 0014); 8: Palmatolepis glabra pectinata M2, sample HS-C-6c, upper view (MUST-RCSP-CON. 0020); 9: Palmatolepis sp., transitional form between Palmatolepis subperlobata and Palmatolepis delicatula delicatula, sample HS-C-W19, reworked conodont, upper view (MUST-RCSP-CON. 0035); 10: Palmatolepis delicatula platys, reworked conodont, sample HS-C-W4, upper view (MUST-RCSP-CON. 0036); 11: Palmatolepis delicatula platys, reworked conodont, sample HS-C-W18 (MUST-RCSP-CON. 0023); 12: Palmatolepis rugosa trachytera, sample HS-C-W-2, upper view (MUST-RCSP-CON. 0028) ......

Fig. 4 Important conodonts from the Hushoot Shiveetiin gol section. 1: Palmatolepis gracilis gracilis, sample HS-C-W-15, upper view (MUST-RCSP-CON. 0026); 2: Palmatolepis gracilis gracilis, sample HS-C-W2, upper view (MUST-RCSP-CON. 0026); 3: Ancyrognathus sp. Sample HS-C-5b (MUSTRCSP-CON. 0037); 4: Polygnathus subnormalis, broken specimen, sample HS-C-6 (MUST-RCSP-CON. 0022); 5: Polygnathus argutus, sample HS-C-W19 upper view (MUST-RCSP-CON. 0038); 6, 7, 8: Polygnathus porrectus, sample HS-C-W1, upper view (MUST-RCSP-CON. 0018); 9: Polygnathus cf. porrectus, sample HS-C-W1, upper view (MUST-RCSP-CON. 0031); 10: Polygnathus aff. porrectus, sample HS-C-W1, upper view (MUST-RCSP-CON. 0032); 11: Polygnathus sp., sample HS-C-W1, upper view (MUST-RCSP-CON. 0027); 12: Icriodus cf. alternatus alternatus, sample HS-C-6 (MUST-RCSPCON. 0017); 13: Icriodus cf. talenti, sample HS-C-W2 (MUST-RCSP-CON. 0001); 14: Icriodus homeomorphus, sample HS-CW1, upper view, reworked conodont (MUST-RCSP-CON. 0025); 15: 
Icriodus aff. homeomorphus, sample HS-C-W1, upper view (MUST-RCSP-CON. 0030), reworked conodont (explanations in the text)

Fig. 5 Amphissites centrocostatus Blumenstengel 1969 (left valve, MUST-RCSP-OST. 0007), from the Palmatolepis rugosa trachytera Biozone of Unit VII, sample HS-C-W1). Note the well-preserved carapace surface sculpture 26

Fig. 6 Lithological log and conodont stratigraphy of the Hushoot Shiveetiin gol section (eastern part). The pyroclastic ash layer (rock sample S11) is a marker horizon which links the eastern and the western part (= rock sample WS-S-11 of the section) of the section. The left column shows the conodont biozones. Conodont biozones shown in black color are clearly indicated by either first appearance (FAD) or the presence of distinct taxa (including data from Suttner et al. 2020); insufficient data or no conodont data are marked with a "?" and are shown in grey color (further explanation in the text). The lithological log is subdivided into sedimentological units (Unit I to Unit IV). Abbreviations: for example "S 19"sedimentology/facies sample, sample numbers shown in pink were taken for geochemistry; "shale 1"sample for geochemistry; "HS-C-1c"-conodont sample (the samples which were taken in an earlier field campaign in 2014 - see Suttner et al. (2020) are also included in this log; samples from the western part were taken in 2018; "F 9"-sample taken for macrofauna. The legend shown in this figure is also valid for the lithological log of the western section—-see Fig. 7). 34

Fig. 7 Lithological log and conodont stratigraphy of the Hushoot Shiveetiin gol section (western part). The pyroclastic ash layer (rock sample WS-S-11) is a marker horizon which links the western and the eastern parts (= rock sample S 11) of the section. The left column shows the conodont zonation. Conodont biozones shown in black color are clearly indicated by either first appearance (FAD) or the presence of distinct taxa (including data from Suttner et al. 2020); insufficient data or no conodont data are marked with an "?" and are shown in grey color (further explanation in the text). The lithological log is subdivided into sedimentological units (Unit IV to Unit VIII). Abbreviations: for example "WS-S 42"sedimentology/facies sample, sample numbers shown in pink were taken for geochemistry; "Wch 9"sample for geochemistry; "HS-C-W17”-sample for conodonts).

Fig. 8 Volcaniclastic sediment discrimination diagrams for the eastern and western sections. Modelled after Wood (1980) and Bhatia and Crook (1986).....

Fig. 9 Coarsening upward sandstones at the top of the Samnuuruul Formation with plant debris (large (?)lycopsid chunk) in Unit VIII of the Hushoot Shiveetiin gol section

Fig. 10 Thin sections illustrating the facies of sampled rocks. a Parallel-bedded, several millimeters-thick layers (fining up) of arkosic sandstone (sample WS-S-4/2); b arkosic sandstone with lithoclasts (reworked channel lag deposit, sample (W-S-5); c matrix-supported polymict conglomeratic sandstone (sample WSS-2); d slightly silicified calcareous siltstone with rare bioclasts (ostracods, sample HS-S-24/2); e larger pyroclastic components are covered preferably isopachous fringe of cement (sample WS-S-25/2). Aragonite (light cement) and Mg-calcite cement (dark cement) have different thicknesses; f pyroclastic ash which is mainly composed of plagioclase with rare quartz components (sample WS-S-35) .41 
Fig. 11 Thin sections illustrating the microfacies of sampled limestones. a Stromatactis in bioclastic wackestone with dissolved brachiopod shell and reworked sediments above (sample HS-S-5). b Strongly bioturbated mudstone/wackestone with sponge spicules, trilobites, ostracods, and cryptostome bryozoans (sample HS-S-10/2). c Wackestone/floatstone with diverse fauna (sample WS-S-30/3). d Wackestone/floatstone with tabulate corals and bryozoans covers a fine-grained bioclastic wackestone with small shell hash and sponge spicules (sample WS-S-36/4). e Strongly burrowed bioclastic wackestone with crionoid ossicles; sample HS-S-4/2). f Laminated limestone exhibits graded bedding which points to transport by wave or storm wave activity; large number of sponge spicules refer to early diagenesis (sample HS-S-1). 42

\section{Chapter 3}

Fig. 1 a Location of the Central Asian Orogenic Belt (CAOB) on a palinspastic map (http://www.palaeos.com) (modified from Blakey (2016), with continent positions and shapes modified from the tectonic data of Hara et al. (2010), Metcalfe (2011), and Xiao et al. (2010); trilobite assemblages modified from Crônier and François (2014)). b Geographical location of the Khovd province, southwestern part of Mongolia, and location of studied section in the Olonbulag Subterrane exhibiting mid-Palaeozoic deposits of the Baruunhuurai Terrane. Geological map of the investigated area: "a" eastern and "b" western Hushoot Shiveetiin gol section (from Munkhjargal et al. 2021).....

Fig. 2 Lithological log, stratigraphical range, and trilobite levels of the Hushoot Shiveetiin gol section, western Mongolia. The figure is changed after Munkhjargal et al. 2021

Fig. 3 Lithostratigraphic column of the 'Samnuuruul' Formation and stratigraphical location of studied phacopid trilobites from Hushoot Shiveetiin gol section

Fig. 4 Phacopid trilobites from the Baruunhuurai Terrane, Olonbulag Subterrane, western Mongolia. (15) Feistops mongoliensis gen. nov. sp. nov., Hushoot Shiveetiin gol section (bed HS-C-5, Palmatolepis glabra pectinata conodont Biozone), Holotype, MUST-RCSP-TRI.-0001, cephalon, respectively, in dorsal, frontal, ventral and lateral views, and detail of the left eye. (6) Feistops mongoliensis gen. nov. sp. nov., Hushoot Shiveetiin gol section (bed HS-C-5, Palmatolepis glabra pectinata conodont Biozone), MUST-RCSP-TRI.-0002, fragmented pygidium in dorsal view. (7-8, 12) Feistops mongoliensis gen. nov. sp. nov., Hushoot Shiveetiin gol section (bed HS-F10, Palmatolepis glabra pectinata conodont Biozone), MUST-RCSP-TRI.-0003, cephalon, respectively, in dorsal, lateral views, and detail of the right eye. (911) Feistops mongoliensis gen. nov. sp. nov., Hushoot Shiveetiin gol section (bed HS-F10, Palmatolepis glabra pectinata conodont Biozone), MUST-RCSP-TRI.-0004, pygidium, respectively, in frontal, dorsal and lateral views. (13) Feistops mongoliensis gen. nov. sp. nov., Hushoot Shiveetiin gol section (bed HSF15, Palmatolepis crepida conodont Biozone), MUST-RCSP-TRI.-0005, pygidium in dorsal view. Scale: $3 \mathrm{~mm}$ (except 5 and 12: $2 \mathrm{~mm}$ ). Schematic representation of a visual surface in Feistops mongoliensis gen. nov. sp. nov., Holotype, MUST-RCSP-TRI.-0001; b a visual surface in Feistops mongoliensis gen. nov. sp. nov., MUST-RCSP-TRI.-0003; c a sagittal profile of anterior part of cephalon in Feistops mongoliensis gen. nov. sp. nov., Holotype, MUST-RCSP-TRI.-0001; d a sagittal profile of anterior part of cephalon in Houseops illustrated in Feist 2019. I-VII: horizontal rows; 1-15 (from the front): vertical files. Grey boxes indicate number of lens present. 
Fig. 5 Phacopid trilobites from the Baruunhuurai Terrane, Olonbulag Subterrane, western Mongolia. (13) Feistops khovdensis gen. nov. sp. nov., Hushoot Shiveetiin gol section (bed HS-C-1, Palmatolepis rhomboidea conodont Biozone), Holotype, MUST-RCSP-TRI.-0006, cephalon, respectively, in frontal, dorsal, and lateral views. (4-6) Undetermined phacopids, Hushoot Shiveetiin gol section (bed HS-C-1, Palmatolepis rhomboidea conodont Biozone), MUST-RCSP-TRI.-0013, pygidium, respectively, in frontal, dorsal, and lateral views. (7-9) Undetermined phacopids, Hushoot Shiveetiin gol section (bed HSC-3, Palmatolepis rhomboidea conodont Biozone), MUST-RCSP-TRI.-0016, exfoliated pygidium, respectively, in frontal, dorsal and lateral views. (10-11) Feistops khovdensis gen. nov. sp. nov., Hushoot Shiveetiin gol section (bed HS-C-1, Palmatolepis rhomboidea conodont Biozone), fragmented cephalothorax, MUST-RCSP-TRI.-0007, respectively, in lateral and dorsal views. (12-13) Undetermined phacopids, Hushoot Shiveetiin gol section (bed HS-C-1, Palmatolepis rhomboidea conodont Biozone), MUST-RCSP-TRI.-0015, mostly exfoliated pygidium, respectively, in dorsal and frontal views. (14) Undetermined phacopids, Hushoot Shiveetiin gol section (bed HS-C-1, Palmatolepis rhomboidea conodont Biozone), MUST-RCSP-TRI.-0014, pygidium in dorsal view. (15-16) ?Feistops sp. A, Hushoot Shiveetiin gol section (bed HS-C-1, Palmatolepis rhomboidea conodont Biozone), MUST-RCSP-TRI.0008, one fragmented cephalon in dorsal view and one partial left cheek from another cephalon and detail of its left eye. Scale: $3 \mathrm{~mm}$ (except 16: $2 \mathrm{~mm}$ ). Schematic representation of a two visual surfaces in Feistops khovdensis gen. nov. sp. nov., Hushoot Shiveetiin gol section, Holotype (bed HS-C-1); b a partial visual surface in ?Feistops sp. A, Hushoot Shiveetiin gol section (bed HS-C-1). I-VII: horizontal rows; $1-15$ (from the front): vertical files. Grey boxes indicate number of lens present

Fig. 6 Phacopid trilobites from the Baruunhuurai Terrane, Olonbulag Subterrane, western Mongolia. (13)?Houseops olonbulagensis sp. nov., Hushoot Shiveetiin gol section (bed HS-F10, Palmatolepis glabra pectinata conodont Biozone), fragmented enrolled exoskeleton, MUST-RCSP-TRI.-0010, respectively, in lateral and ventral views, and detail of the vincular furrow. (4-6)?Houseops olonbulagensis sp. nov., Hushoot Shiveetiin gol section (bed HS-F10, Palmatolepis glabra pectinata conodont Biozone), fragmented unrolled exoskeleton, MUST-RCSP-TRI.-0011, respectively, in dorsal views and detail of the right eye. (7-8)?Houseops olonbulagensis sp. nov., Hushoot Shiveetiin gol section (bed HS-F10, Palmatolepis glabra pectinata conodont Biozone), Holotype, MUST-RCSP-TRI.-0009, fragmented cephalothorax, respectively, in lateral and dorsal views. (9)?Houseops olonbulagensis sp. nov., Hushoot Shiveetiin gol section (bed HS-C-5, Palmatolepis glabra pectinata conodont Biozone), one thoracopygon associated to one pygidium in dorsal view, MUST-RCSP-TRI.-0012. Scale: $3 \mathrm{~mm}$ (except 6: $2 \mathrm{~mm}$ ). Schematic representation of a visual surface in ?Houseops olonbulagensis sp. nov., Hushoot Shiveetiin gol section, Holotype (bed HS-F10); b sagittal profiles of anterior part of cephalon in ?Houseops olonbulagensis sp. nov. (Holotype), and Houseops illustrated in Feist 2019. I-VII: horizontal rows; 1-15 (from the front): vertical files. Grey boxes indicate number of lens present .78

\section{Chapter 4}

Fig. 1 Topographic map of Mongolia with location of the Main Mongolian Lineament and the southern structural units/terranes south of the Main Mongolian Lineament. Modified after Badarch et al. (2002). Asterisk marks the research area.

Fig. 2 Plate tectonic reconstruction of the Palaeo-Asian Ocean during the Late Devonian published in Safonova et al. (2017; see references therein). Abbreviations for continental blocks: CM, Central 
Mongolia; Dz, Dzabkhan (Baydrag); SG, South Gobi; JR, Junggar; KAZ, Kazakhstan; NC, North China; NT, North Tienshan; ST, South China; RA, Rudny Altai; SIB, Siberian Craton. South Gobi at that time is placed around $40^{\circ}$ to the north 91

Fig. 3 Main terranes of Mongolia (modified after Badarch et al. 2002), published in Safonova et al. (2017). The numbers in circles indicate intra-oceanic arcs and their hosting terranes: 8, Dariv; 9, KhanTaishirin; 10, Dzhida; and 17, Gurvansayhan-Zoolen terranes

Fig. 4 Geological map of the working area (Mushgai, southern Mongolian Gobi, Umnugobi Province, Mandalovoo area) and the sections investigated (the stippled line represents those parts of the section we have summarized). Study area \#1 is composed of three sections (hills A-C, Ordovician to Silurian rocks; see lithological log Fig. 5); area \#2 is composed of three sections (Lower Devonian to Mississippian rocks; see lithological logs Figs. 8, 11, and 12).

Fig. 5 Compiled lithological log of three hills (sections A to C, \#1 in Fig. 4) along the road west of the Olon Ovoot gold mine (Khoyormod Formation, Ordovician; Mandalovoo Formation, Gavuu Member, Silurian), Bayankhoshuu Ruins area, Umnugobi Province. Sample numbers: "C" = conodont samples, "S" $=$ sedimentology/facies, "GC" = samples for geochemistry

Fig. 6 Microfacies of the Khoyormod Formation; a echinoderm packstone shows a condensed fabric. The parallel set of stylolites originates from selected pressure solution. The components produce a puzzle-like fabric and are surrounded by solution seams (sample BR-S-1); b fossiliferous micritic limestone with irregular anastomosing set of stylolites underlain by a fossiliferous limestone with corals and echinoderms (sample BR-S-5); c fossiliferous wackestone with micritic matrix. The sediment is slightly burrowed and shows an irregular anastomosing set of stylolites (sample BR-S-6); d floatstone with large bioclasts (e.g., trilobites, echinoderms, brachiopods), small shell hash, and rare corals and bivalves. The iron-stained matrix is clayey to micritic (sample BR-S-4) .97

Fig. 7 Field photographs showing lithological units and sedimentological features observed in the Bayankhoshuu Ruins section, Mandalovoo Formation: a alternation of reddish crinoidal grainstone and micritic limestone of the Ordovician Khoyormod Formation (Bayankhoshuu Ruins area, Umnugobi Province; photo taken close to sample BR-S-2). b massflow deposits of the Gavuu Member with reworked corals (Mandalovoo Formation; photo taken from sample close to BR-S-7). c Greywacke with flute casts at the lower surface, Hanyndoloon Member (Mandalovoo Formation, cross-section near the Bayankhoshuu Ruins). d Bioherm of the Orgol Formation, cross-section near the Bayankhoshuu Ruins, Umnugobi Province; the Dungenee Formation is shown here in front of the Orgol Formation. e Sandstone and conglomerate of the Takhuul Member, Botuulkhudag Formation (cross-section near the Bayankhoshuu Ruins, Umnugobi Province; photo taken from the base of the section around sample BRS-15). 99

Fig. 8 Lithological log of the Botuulkhudag Formation, Takhuul Member, and the lower part of the Minjin Member (cross-section near the Bayankhoshuu Ruins, Umnugobi Province). Base of the section:

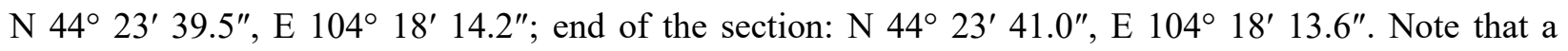


detailed lithological $\log$ of the section within the basalts is shown in Fig. 11. Sample numbers: "C" = conodont samples, "S" = sedimentology/facies, "GC" = samples for geochemistry.

Fig. 9 Microfacies/lithology of the Botuulkhudag Formation, Takhuul Member; a arkosic sandstone at the base of the Takhuul member (sample BR-S-15); b various clasts of the conglomerate; fossiliferous limestone clasts with excellent preserved corals; reworked material with geopedals (sample BR-S-18); c detailed view of the conglomerate matrix showing the sedimentary clasts with sand and smaller-sized particles filling the spaces between them. The largest pebbles are about $10 \mathrm{~mm}$ across (sample BR-S-20); d-f fossiliferous wackestone to floatstone representing the carbonate boulder from the conglomerate (samples BRS-18, BR-S-20); note the diverse fauna such as corals, crinoids, and brachiopod shells; $\mathbf{g}$ calcareous sandstone of the upper part of the Takhuul Member (sample BR-S-21); components are subangular to subrounded and the sediment contains extraclasts (shale); h moderately sorted thick-bedded sandstone at the top of the Takhuul Member 103

Fig. 10 Field photographs (a-e) showing lithological units and sedimentological features of the Minjin Member, Bayankhoshuu Ruins section; a overview of the micritic limestone (blueish color) shales and bentonite (grayish and whitish rocks) which are covered by basalts (brownish color), view to the North; Botuulkhudag Formation, Minjin Member (cross-section near the Bayankhoshuu Ruins, Umnugobi Province); b detail of thick-bedded bentonite (sample BR-GC 17), Botuulkhudag Formation, Minjin Member (cross-section near the Bayankhoshuu Ruins, Umnugobi Province); c detail of pyroclastic rock (sample BR-GC 40; see Fig. 10), Botuulkhudag Formation, Minjin Member (cross-section near the Bayankhoshuu Ruins) generated by explosive fragmentation of magma and/or previously solid rock during the course of volcanic eruptions; $\mathbf{d}$ detail of pyroclastic rock with inverse gradation (sample BR-S43; see Fig. 10), Botuulkhudag Formation, Minjin Member (cross-section near the Bayankhoshuu Ruins, Umnugobi Province) which exhibits inverse gradation; e large pillows in the upper part of the Minjin Member, Botuulkhudag Formation (cross-section near the Bayankhoshuu Ruins, Umnugobi Province); $\mathbf{f}$ thin section of a pyroclastic rock with inverse gradation, Minjin Member (sample BR-S-43; see Fig. 11)

Fig. 11 Lithological $\log$ of the Botuulkhudag Formation, Minjin Member (detailed section in between pillow basalts; see Fig. 8; Bayankhoshuu Ruins section, Umnugobi Province). Base of the section: $\mathrm{N}^{\circ}{ }^{\circ}$

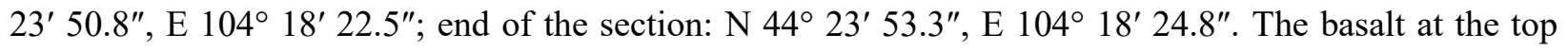
corresponds with the basalt at the base shown in Fig. 12. Sample numbers: "F" = fauna samples, "S" = sedimentology/facies, "GC" = samples for geochemistry . 106

Fig. 12 Lithological log of the Botuulkhudag Formation (Minjin Member) and the Arynshand Formation.

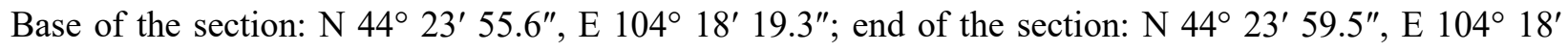
27.5". Sample numbers: "C" = conodont samples, "F" = fauna samples, "S" = sedimentology/facies, "GC" = samples for geochemistry 107

Fig. 13 Radiolarians and conodonts found in the Minjin Member: a, b Trilonche cf. $T$. davidi (Hinde); $\mathbf{a}=$ sample number BR-F-3; b = sample number BR-F-5; $\mathbf{c}=$ Trilonche sp., sample number BR-F-5; d-k Helenifore cf. H. robustum (Boundy-Sanders and Muchey); $\mathbf{d}-\mathbf{i}=$ sample number BR-F-3; $\mathbf{j}-\mathbf{k}=$ sample number BR-F-4; l, m Trilonche cf. T. minax (Hinde), sample number BR-F-6; n, o Polygnathus pollocki 
Druce, sample BR-F-5; p, q Polygnathus angustidiscus Yongquist, sample BR-F-4. Scale bars $=100 \mu \mathrm{m}$ 108

Fig. 14 Microfacies/lithology of the Botuulkhudag Formation, Minjin Member, and examples from the Arynshand Formation: a micritic limestone with radiolarians. In the middle part of the thin section, a thin intercalation of siltstone occurs deposited as distal turbidite or as a result of bottom currents in basinal facies setting (Minjin Member, sample BRS-28); b Wackestone with rare crinoids, base of the Arynshand Formation (Early Mississippian, sample BR-S-31); c moderately sorted crinoid packstone, syntaxial rim cement (arrows) indicate continuous growth of crinoid calcite under burial conditions (sample BR-S-38); d monomict breccia at the upper part of the Arynshand Formation; some calcite veins postdate brecciation (sample BR-S-39); e Field photograph of limestone breccia with red shales; $\mathbf{f}$ red shales at the top of the Arynshand Formation, photo taken around sample BR-F-9; g poorly sorted, densely packed crinoid packstone which shows strong compaction and pressure solution indicated by stylolitic boundaries between crinoid fragments (sample BR-S-38) 110

Fig. 15 Conodonts from Ordovician and Devonian/Carboniferous: a Walliserodus cf. amplissimus or Hamarodus sp. b Palmatolepis cf. gracilis gracilis Branson \& Mehl, 1934a incomplete and highly altered species. c Polygnathus cf. longiposticus Barnson \& Mehl 1934a. d Polygnathus communis cf. renatae, Corradini et al. 2003. e Polygnathus inornatus Branson \& Mehl, 1934b. f Siphonodella sp. (cf. duplicata?), g Siphonodella cf. duplicata, h Bispathodus cf. spinulicostatus (Branson 1934). i Polygnathus sp. j Siphonodella cf. duplicata. k Gnathodus pseudosemiglaber Thompson \& Fellows, 1970. I Polygnathus cf. longiposticus. m Polygnathus cf. tenuiserratus M1, Corradini et al. 2003. n Siphonodella crenulata Cooper 1939. o Siphonodella sp. p Bispathodus stabilis Branson \& Mehl 1934a. q Scaliognathus cf. anchoralis europensis Lane \& Ziegler 1983. r Siphonodella sp. s Polygnathus purus purus Voges 1959. t Scaliognathus anchoralis anchoralis Barnson \& Mehl 1941. u Scaliognathus anchoralis europensis Lane \& Ziegler 1983. v Polygnathus purus purus Voges, 1959. Scale bars $=100$ $\mu \mathrm{m}$

Fig. 16 Stratigraphic chart of formations/members of the Bayankhoshuu Ruins section combined with tectonic and volcanic events (unconformity/hiatus, basalts/pyroclastic deposits) of southern Mongolia, Mandal Ovoo area (Umnugobi Province) based on published data (Minjin et al. 2001; Wang et al. 2003, 2005) and our results. The right column shows a composite lithological log of the investigated sections. The succession is mainly composed of pelagic/hemipelagic sediments and exhibits different subaerial and submarine volcanic phases. For more details, see figures and explanations in the text 115

\section{Chapter 5}

Fig. 1 Stratigraphic chart of formations/members of the Bayankhoshuu Ruins section combined with tectonic and volcanic events of southern Mongolia, Mandal Ovoo area. 131

Abb. 1 Stratigraphische Karte der Formationen/Member des Profils Bayankhoshuu Ruins in Verbindung mit tektonischen und vulkanischen Ereignissen der südlichen Mongolei, Gebiet Mandal Ovoo. 138 


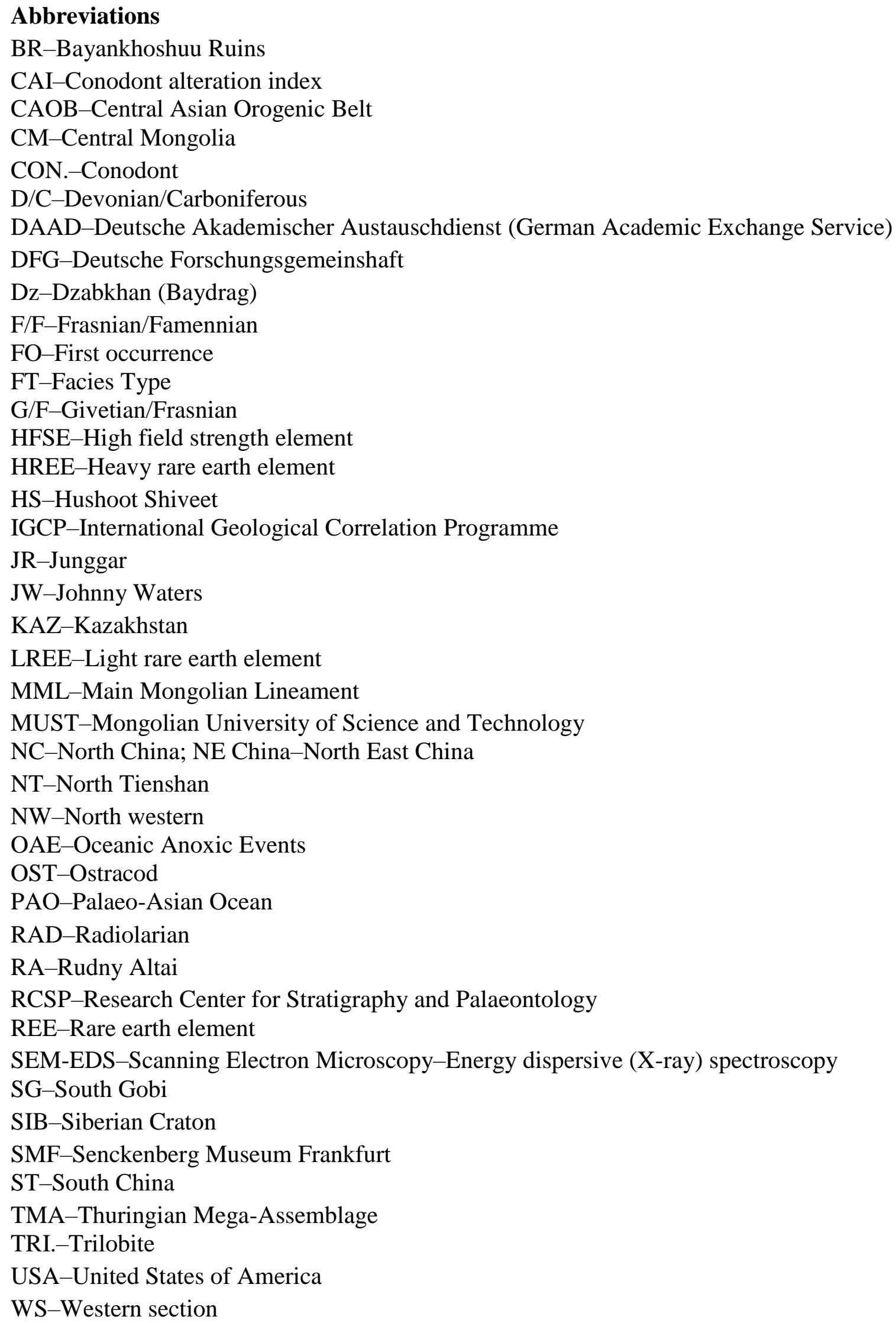




\section{Chapter 1}

\section{Introduction}

\section{Topic}

This thesis is primarily concerned with Palaeozoic successions within the Central Asian Orogenic Belt (CAOB), in order to get a better understanding of biodiversity patterns in isolated ecosystems. Studies addressing problems of palaeogeographic sample bias, biostratigraphy and extinctions in the mid-Palaeozoic in a rather unstudied area. Results of two other papers (Waters et al. 2021; Roelofs et al. 2021) are mentioned in the summary, in order to provide a complete summary of the work in Mongolia.

\section{Inhalt}

Diese Dissertationschrift beschäftigt sich im Wesentlichen mit paläozoischen Abfolgen innerhalb des Zentralasiatischen Orogengürtels (CAOB), um ein besseres Verständnis der Biodiversitätsmuster in isolierten Ökosystemen $\mathrm{zu}$ erhalten. Die Studien befassen sich mit Problemen der Limitierung von Proben auf bestimmte paläogeographische Regionen, der Biostratigraphie und des Aussterbens im mittleren Paläozoikum in einem eher unerforschten Gebiet. Ergebnisse von zwei weiteren Publikationen (Waters et al. 2021; Roelofs et al. 2021) sind in der Zusammenfassung berücksichtigt, um die gesamten Ergebnisse der Arbeit in der Mongolei darzustellen.

\section{Significance}

Mongolia covers a huge area in Asia and provides excellent Palaeozoic successions although large regions still lack detailed information on fauna and flora in Palaeozoic rocks. Of special interest is the Central Asian Orogenic Belt (CAOB), one of the largest collisional complexes on Earth. The CAOB is composed of a large number of terranes, continental margins, island arcs, backarc/forearc basins and accretionary wedges (Badarch et al. 2002; Safonova et al. 2017). Many terranes and regions underwent strong metamorphism, such as areas north of the Main Mongolian Lineament. To the south, Palaeozoic rocks exhibit low-grade metamorphism, thrusting and folding. Two promising long successions of Palaeozoic rocks were studied, namely the Hushoot Shiveetiin gol section and the Bayankhoshuu Ruins section (Fig. 1).

The intention of the $\mathrm{PhD}$ was to study marine facies settings in Palaeozoic rocks of southern and southwestern Mongolia, in an area little is known in terms of biostratigraphy and events. In order to get a better understanding on events and what might have been the driving forces I studied sections in Mongolia which have not been in the focus of research in the last decades. In order to complement studies on Late Devonian events elsewhere, I decided to study sections in open ocean environments (CAOB), far away from mainly studied epicontinental areas. 
As stated in many publications, events are the driving force for evolution. They exhibit dramatical changes in the palaeontological record of organisms and they are often associated with dramatic extinctions (Walliser 1996) and anoxic sediments (but not always). Mass extinctions are episodes in which a large number of plant and animal species became extinct within a few thousand to a hundred thousand years. Most events (first and second order events) are traceable worldwide. For instance, in the Late Devonian, mass extinction events recognized at the Frasnian-Famennian (F/F) stage boundary and at the Devonian-Carboniferous (D/C) boundary (McLaren and Goodfellow 1990; Sepkoski 1996; Walliser 1996). Overall, 19\% of all families, $50 \%$ of all genera and at least $70 \%$ of all species became extinct (Raup and Sepkoski 1982; Sepkoski 1996; McGhee et al. 2013), but extinctions also concerned palaeoecosystems and due to Late Devonian events whole coral/stromatoporoid reef ecosystems became extinct. What might be the reason(s) for these dramatical changes? Why did the carbonate factory brake down? There are several reasons which have been discussed. For instance, extraterrestrial bolide impacts (McLaren 1970), anoxia within the water column due to climate changes (House 1985; Becker and House 1994; Caplan and Bustin 1999; Bond and Wignall 2005), transgressions and regressions (Newell 1967; Hallam and Wignall 1999; Purdy 2008; Ruban 2010, 2013; Smith and Benson 2013), eutrophication and increased sediment transport (Joachimski et al. 1993; Schobben et al. 2016), explosive volcanism (Paschall et al. 2019) and/ or large igneous provinces (LIP's, Ernst et al. 2019; Racki et al. 2020, among others) and much more has been considered. The main problem is that previous studies preferably have been done along former epicontinental margins between Laurassia and Gondwana. Less information is available in deep open oceanic successions and shallow-water areas around island arcs. Generally, events are characterized by bituminous rocks, such as black limestones and shales within marine realms, but they do not necessarily occur everywhere (see Carmichael et al. 2016). So, the question was: "Can we recognize Palaeozoic event layers or equivalents in the CAOB?" If so, is this comparable to already published data? What might be the main trigger, as there are many reasons still in discussion? And finally, what has happened in the aftermath of those events as it seems that the CAOB may have acted as a refugium for at least some groups, such as for crinoids (Waters and Webster 2009; Tolokonnikova and Ernst 2010).

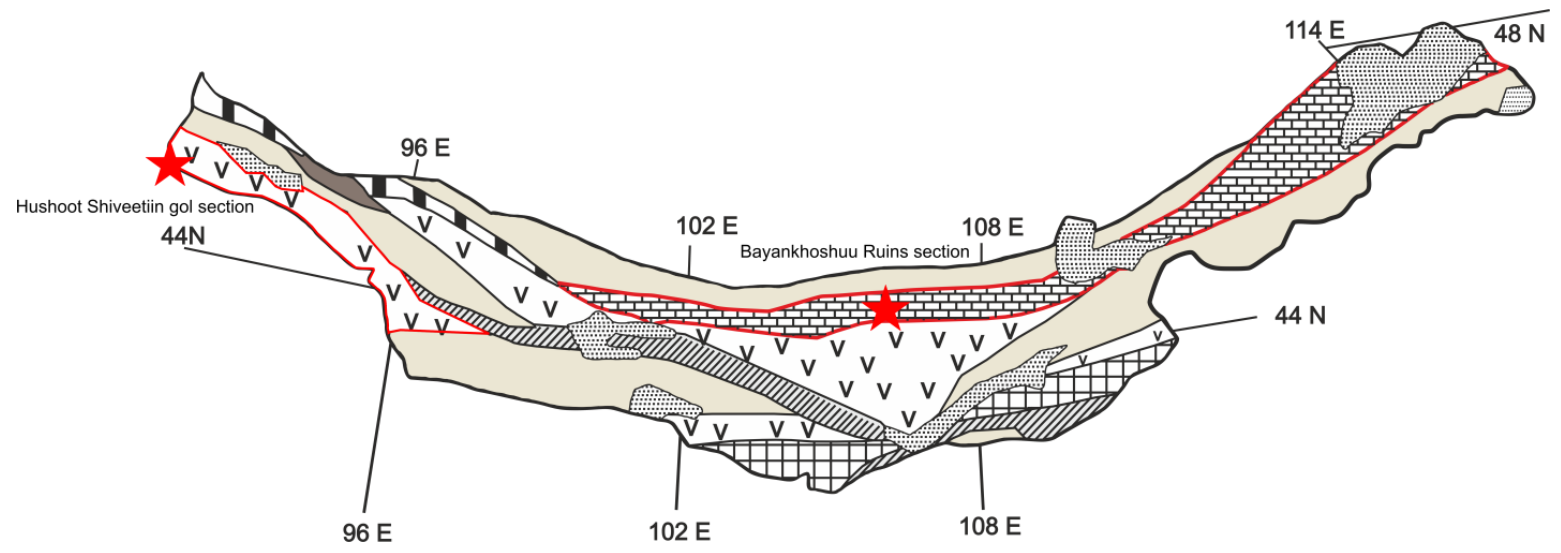

Fig. 1 Investigated sections (red asterisks) in southern and south-western Mongolia during the years 2018/2019. 
In this thesis, I will provide data from isolated ecosystems from a rather unstudied region, which will complement studies from other parts of the World.

\section{State of the art}

In the mid-Palaeozoic a number of fundamental faunal changes (extinctions) occurred, some of which are considered to be a result of dramatic climate changes. These extinction events left not only biological modifications in the geologic record, but are closely associated with geochemical signals of ocean oxygen loss (anoxia), and are typically (but not always) preserved as black shales or bituminous limestones in Devonian marine sediments. The association of Late Devonian oceanic anoxia events with extinction events has long been considered ubiquitous, and ocean anoxia has been the accepted "driving force" for these marine mass extinctions for the past three decades (House 1985; Becker and House 1994; Caplan and Bustin 1999; Bond and Wignall 2005), although there has recently been some debate about the role of anoxia on extinction (George et al. 2014; Song et al. 2017). While there are many anoxic intervals during the Middle to Late Devonian, the most severe include the Kellwasser events (associated with the F/F extinction event), and the Hangenberg Crisis (associated with the D/C extinction event). The Frasnian/Famennian Event is one of the Big Five extinction events first published by Raup and Sepkoski (1982). Subsequent work has shown that a number of biodiversity crises occurred in the Middle and Late Devonian including the Givetian/Frasnian (G/F) Event, the Frasnian/Famennian (F/F) Event and the Devonian/Carboniferous (D/C) Event. Taxonomic severity ranking of the 11 largest Phanerozoic biodiversity crises by Sepkoski (1996), Bambach et al. (2004), Bambach (2006), and McGhee et al. (2012) have placed these Devonian biodiversity crises in the range of top nine events in severity index ranking. In an attempt to expand the discussion of biodiversity crises beyond measures of taxonomic loss in the extinction events, McGhee et al. (2013) developed a new ecological severity ranking which accounted for ecological impact of biodiversity loss rather than just magnitude of biodiversity loss. Using this new method of analysis, the authors ranked the F/F Event as the fourth most ecologically severe crisis in the Phanerozoic of the six events ranked, while the G/F Event was a significant extinction event for echinoderms and bryozoans resulting in a replacement of endemic marine faunas by more cosmopolitan ones (McGhee et al. 2013). Areas where the anoxic Kellwasser events and Hangenberg Crisis are recognized include locations throughout North America and Europe, such as Germany, Montagne Noire (France), Prague Syncline (Czech Republic), Cantabrian Mountains (Spain), Northwest Territories (Canada), Holy Cross Mountains (Poland), the central and southern Appalachians (eastern United States) and the Great Basin of Utah and Nevada (western United States) (e.g. Bond et al. 2004; Bond and Wignall 2005; Buggisch and Joachimski 2006; Izokh et al. 2009; Aretz 2021; Aretz and Corradini 2021) whereas Asia (except China) is underrepresented (Komatsu et al. 2014; Carmichael et al. 2014, 2016; Paschall et al. 2019; Racki et al. 2019) and some areas lack detailed information such as from Mongolia (Fig. 2). However, there is still debate about the cause/effect relationship between anoxia and extinction in the Devonian (Bratton et al. 1999; Copper 2002; Joachimski and Buggisch 2002; 
George et al. 2014; Song et al. 2017; Shizuya et al. 2019; Aretz 2021), as the epeiric seas and tectonic basins of eastern North America and Europe generally show a close association between the two (Bond and Wignall 2009 and references therein) but sites elsewhere (particularly in Australia) do not (Becker et al. 1991; Bratton et al. 1999; George et al. 2014; Racki et al. 2019). Others have suggested that climate cooling rather than anoxia was the cause of the mass extinction (Copper 1986; Joachimski and Buggisch 2002; Song et al. 2017; Huang et al. 2018). Furthermore, there are other anoxia events in the Devonian that do not appear to be related to widespread extinction events at all (Brett and Baird 1995; Becker et al. 2012).

Thus, our current knowledge for instance of the F/F extinction event is limited by significant sampling bias, as most previous studies sampled epicontinental seaways or passive continental shelves, primarily from localities across Europe and North America, which together formed a single equatorial continent with a rising mountain chain during the Late Devonian. Our methods of recognizing Late Devonian events are thus based on signatures from a restricted set of palaeoenvironments that may not represent typical Late Devonian oceanic conditions. In the last decade, new methodologies and research in additional palaeoenvironments (e.g. Königshof et al. 2012, 2016, 2017a, 2017b, 2021; Carmichael et al. 2014, 2016; Racki et al. 2019, Aretz and Corradini 2021 [eds.] and references therein) around the world confirm that the Kellwasser events and the Hangenberg Crisis were global in scope, but its expression depends on both palaeoenvironment and palaeogeography. A comparable sampling bias is obvious for the Hangenberg Crisis (see Komatsu et al. 2014; Kaiser et al. 2015; Zhang et al. 2018; Paschall et al. 2019).

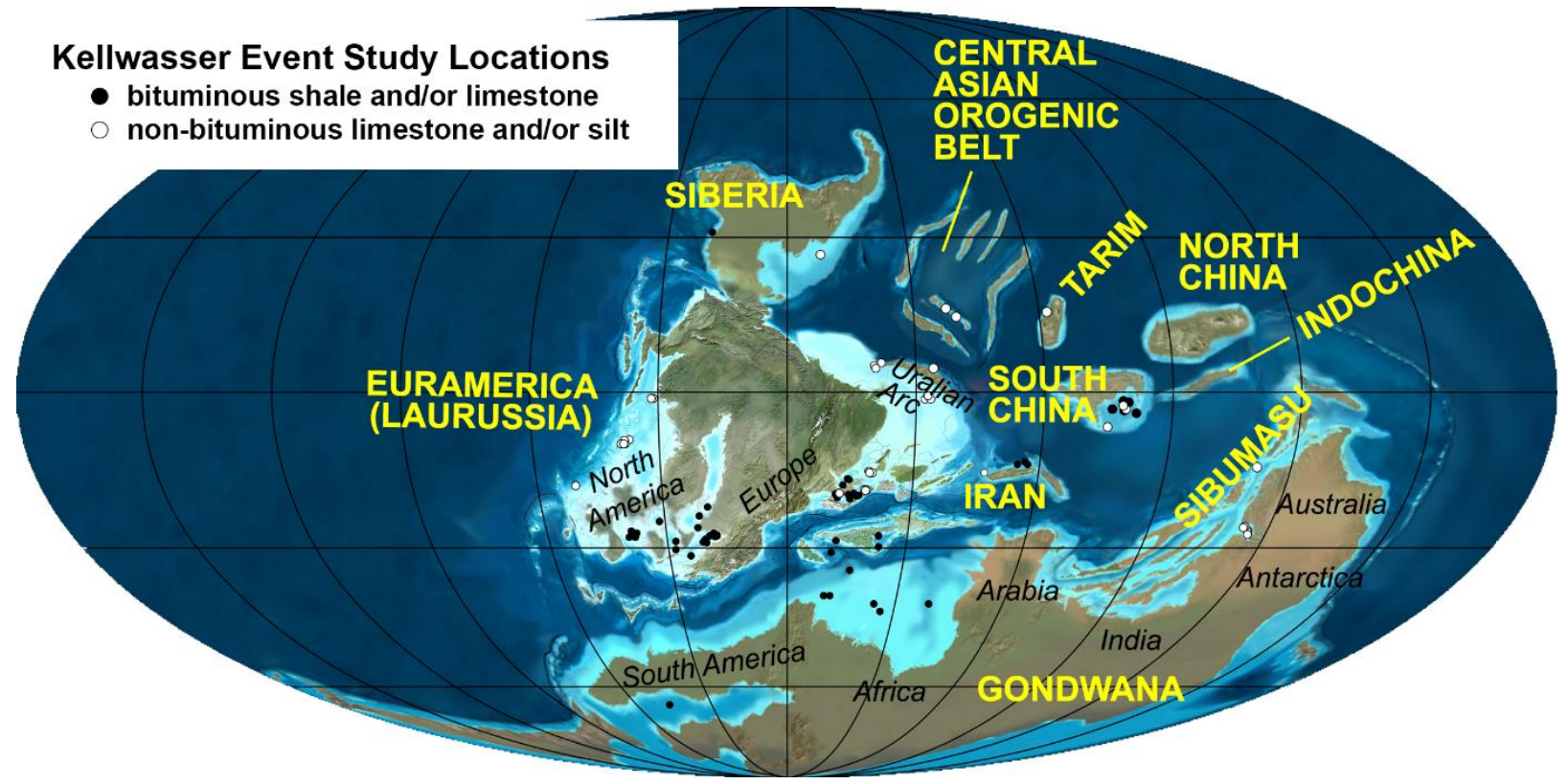

Fig. 2 Palaeogeographic map of the Late Devonian (base map from Blakey 2016).

Only by studying the many differing expressions of both biotic crisis in a wide variety of palaeoenvironments we can begin to fully comprehend the mechanisms of global ocean anoxia 
and extinction e.g. at the F-F stage boundary and the D/C boundary, and determine the trigger mechanism(s) that led to this catastrophic marine biodiversity crisis. The CAOB is clearly an essential yet grossly understudied part of the story of the Late Devonian extinctions and ecosystem rebound from extinctions (see review by Carmichael et al. 2019, and Racki et al. 2020).

\section{Objectives}

The sections exhibit nearly complete island arc sequences ranging from the Late Devonian to the Early Carboniferous in shallow-water (Hushoot Shiveetiin gol) and hemipelagic palaeoenvironments (Bayankhoshuu Ruins). In the frame of this research project I tried to answer the questions below and to test the following hypothesis:

- Can we recognize anoxia in these isolated island arcs, and can we correlate the two sections with each other? Because correlation of the two sections from different terrains will also allow us to test, whether the influx of volcanism around $\mathrm{D} / \mathrm{C}$ boundary is regional or may have affected a large area as it is suggested for the F/F boundary (Racki et al. 2018)

- Investigation of the two sections of the CAOB will also contribute to answer the question which mechanism for anoxia (which does not necessarily show up as black shales or limestones in the lithological record)-either "top down" (surface eutrophication) or "bottom up" (upwelling of anoxia)-is more likely in open ocean sediments. According to Carmichael et al. (2014), shallow-water eutrophication caused by enhanced nutrient loading is the main cause for the events within the CAOB. But this is based on one section only. Thus, we need more data to confirm this hypothesis.

- The western Mongolian Hushoot Shiveetiin gol section exhibits mainly monospecific macrofauna (e.g. carbonates are mainly composed of monospecific brachiopods). Is this somehow linked with the volcanic activity at that time? Is this a more local effect or is the monospecific macrofauna also visible in the other, more hemipelagic section? Are these observations in contradiction to the data published by Tolokonnikova and Ernst (2010) and Waters and Webster (2009) which consider the CAOB as a refugium and a center of origination for echinoderms and bryozoans? Thus, it is important to investigate how the biodiversity patterns look like in both sections before and after the event layers.

- Finally I want to increase the resolution in terms of biostratigraphy, lithostratigraphy and sedimentology of Palaeozoic sequences in the Mushgai region, Southern Mongolia. 


\section{Study sites}

4.1. Southwestern Mongolia, Baruunhuurai Terrane, Samnuuruul Formation

IGCP 596 and its successor, the southwestern Mongolia working group, have been conducting fieldwork in Mongolia with the goal of identifying Late Devonian extinctions and anoxia events that were previously recognized in coeval CAOB terranes in western China. Fieldwork in 2012, 2014, and 2018 identified three sections in the Samnuuruul Formation, Baruunhuurai Terrane, and Olonbulag Subterrane for detailed study (Kido et al. 2013; Ariunchimeg et al. 2014; Suttner et al. 2020). Deposits of the Baruunhuurai Terrane have a stratigraphic range from Devonian to Carboniferous and are located in the southwestern part of Mongolia close to the border to China (Badarch et al. 1998). The Samnuuruul Formation is approximately $450 \mathrm{~m}$ thick consisting of reddish brown conglomerates, thin limestone beds, greenish gray and gray, fine- to mediumgrained sandstone, and siltstone with a significant volcaniclastic component. Three field localities were examined in detail for biostratigraphy and microfacies analysis: Buduun Khargait

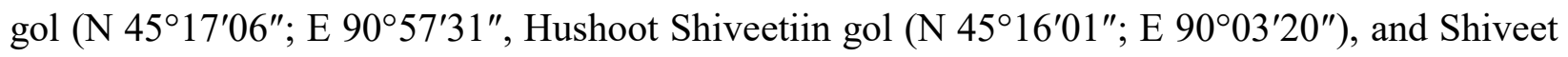

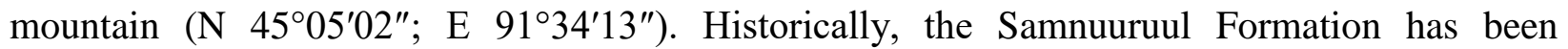
assigned a Famennian (Late Devonian) age based on macrofossils. Suttner et al. (2020) reported conodonts at Hushoot Shiveetiin gol from the Palmatolepis minuta minuta to Palmatolepis rhomboidea Biozones (Spalletta et al. 2017) confirming a Famennian age for the formation.

The investigated Hushoot Shiveetiin gol section is located in the Olonbulag Subterrane. The section is primarily composed of siliciclastic rocks including volcaniclastic deposits. Limestones occur in a limited number of thin-bedded layers containing various fossils, such as corals, bryozoans, brachiopods, and conodonts, which support a Famennian age (see earlier studies by Bolshakova et al. 2003; Kido et al. 2013; Ariunchimeg et al. 2014; Suttner et al. 2020). The uppermost part of the Samnuuruul Formation consists of a series of arkosic sandstones, and conglomeratic sandstones with plant fossils, which most probably are (?)Early Mississippian in age.

\subsection{Southern Mongolia, Mandalovoo Terrane, Mushgai region}

Mongolia is divided by the Main Mongolian Lineament (MML) into a northern and southern domain. The MML separates preferably Precambrian and Lower Palaeozoic rocks in the north from Lower and Upper Palaeozoic rocks in the south. Mid-Palaeozoic deposits cover a huge area south of this lineament. The investigated second section within the CAOB belongs to the Mandalovoo Terrane or the Gurvansayhan Terrane, a narrow and long belt in the northern part of southern Mongolia which extends to the east into NE China (Badarch 2002).

We conducted fieldwork in the northern part of this region. Geographically, the research area is located $50 \mathrm{~km}$ south-east from Mandal-Ovoo soum, Umnugobi province, southern Mongolia (approximately $600 \mathrm{~km}$ from Ulaanbaatar, Mongolia). 
The Mandalovoo and Gurvansayhan Terrane are island arc terranes and consist mainly of ophiolites, tholeiitic to calc-alkaline volcanic and volcaniclastic rocks. It contains a stratigraphic succession of Ordovician to Carboniferous volcanic and sedimentary rocks including Ordovician and Silurian sandstone, argillite, fossiliferous limestone, Lower-Middle Devonian conglomerate, sandstone, shallow-marine fossil-rich limestone, felsic tuff, Upper Devonian pillow basalt, andesite, tuff, volcaniclastic sandstone, chert, and Mississippian (Lower Carboniferous) marine sedimentary rocks (Lamb and Badarch 2001). First research goes back to the 1976 and 1977, which took place in the frame of a Mongolian-Russian expedition in this area (Suetenko et al. 1977; Alekseeva et al. 1993).

The most recent geological descriptions of this area are published in the 2001 IGCP Guidebook (Minjin). This report (Minjin et al. 2001) provides useful information on various fossils found in this area, but lacks detailed information on sedimentology, events, facies, volcanism and detailed biostratigraphy.

We have sampled three sections, ranging from the Late Ordovician to Silurian along a road west of the Olon Ovoot gold mine and a cross-section near the Bayankhoshuu Ruins (Middle Devonian to Early Carboniferous) further in the north. The Bayankhoshuu Ruins section exhibits a mixture of sedimentary rocks, volcanic rocks (basalts, pillow basalts, ?andesites, felsic volcanics) and volcaniclastic rocks, it contains more than 20 bentonite layers, some of them have a thickness of up to 1 meter. Sections are tectonized at all scales from $\mathrm{cm}$ to $\mathrm{km}$.

\section{Materials and applied methods}

I conducted the study in two stages, which involved field survey and laboratory work/desktop study. The field survey included 2 years of field work. During the fieldwork, necessary samples were collected from research sites for facies analysis and conodont biostratigraphy. The desktop study included laboratory work and paper writing. A multidisciplinary approach was chosen, which resulted in collaboration with researchers from the USA, France, Thailand and Turkey. In the frame of this research group I worked on sedimentology, facies and biostratigraphy.

The Appalachian working group applied various geochemical methods which were performed at the Appalachian State University. Based on our multi-proxy approach I will provide biostratigraphical and sedimentological data from island arc environments which will help to get a better understanding of the Late Devonian open ocean palaeoenvironmental settings of the CAOB.

\section{Microfacies and biostratigraphy:}

Microfacies classification was performed at the Senckenberg-Research Institute and Natural History Museum, Frankfurt. Samples for thin sections have been taken whenever facies changes occurred. In the field, small-scaled (cm-size) lithological and facies descriptions were done. In a later step these field descriptions were summarized in lithological logs as shown in the publications. In total, 58 thin sections (Fig. 3) from Hushoot Shiveetiin gol (south-western 
Mongolia) section and 57 thin sections from Bayankhoshuu Ruins section (south Mongolia), $7.5 \times 11 \mathrm{~cm}$ in size, were used for facies analysis. Facies analysis requires large thin-sections in order to get a fundamental overview of facies in distinct layers and avoid misinterpretations by using small-sized thin sections.

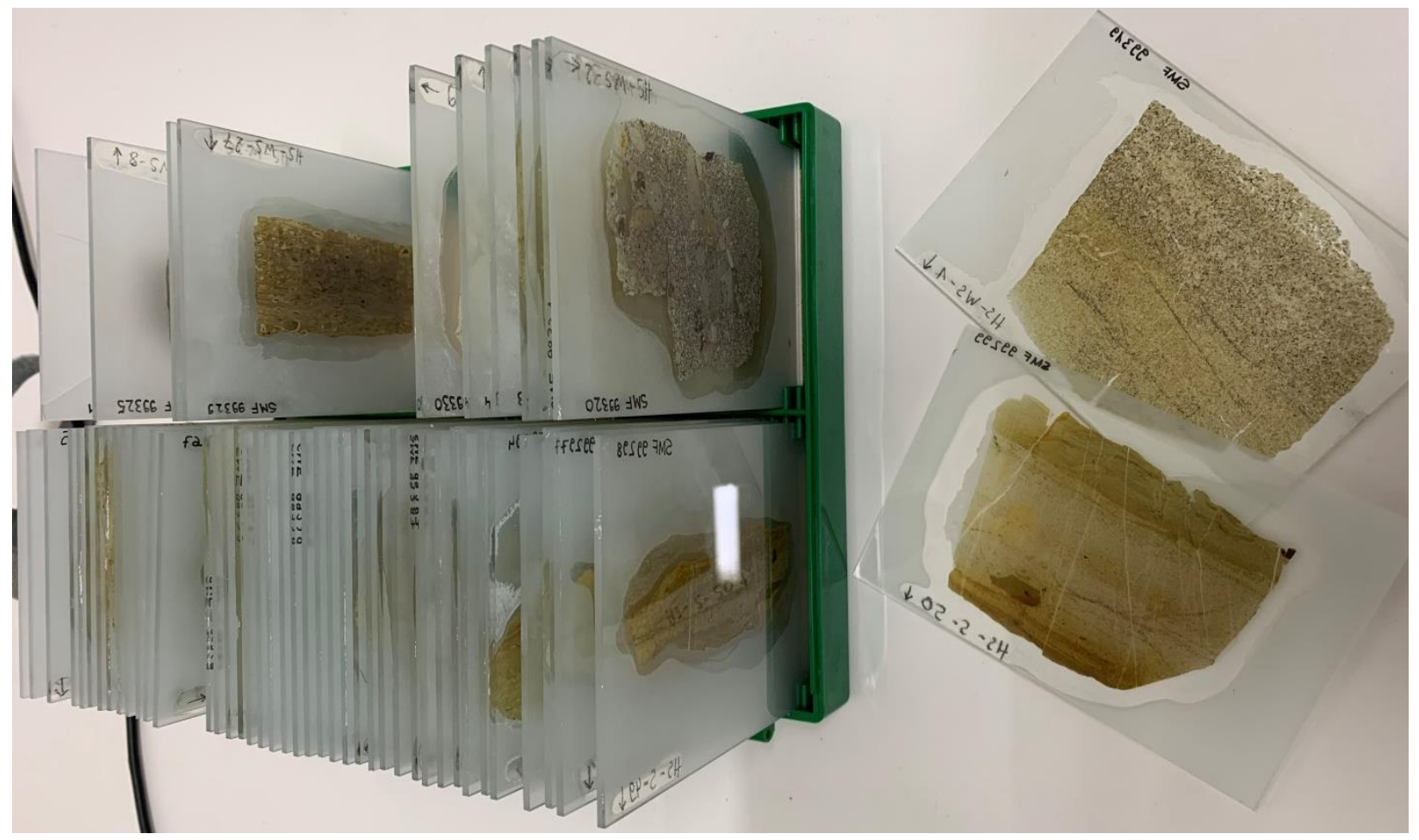

Fig. 3 Thin sections from Hushoot Shiveetiin gol section, southwestern Mongolia. Size $7.5 \times 11 \mathrm{~cm}$.

\section{Biostratigraphy:}

Conodont extraction and classification was done at Senckenberg-Research Institute and Natural History Museum, Frankfurt. Conodont preparation as well as picking conodonts from the residue is a long-lasting procedure. The preparation process was done under the guidance of the technical assistant Jana Anger. Conodonts have been determined on genus-level; more detailed taxonomy was done by my supervisor, Dr. Peter Königshof. Furthermore, other faunas such as ostracods, microvertebrates and trilobites have been picked and prepared for further analysis.

All in all, 44 limestone samples from Hushoot Shiveetiin gol section and 51 samples from Bayankhoshuu Ruins section were cleaned and crushed to about $2 \mathrm{~cm}^{3}$ and placed in wide-mesh sieves hung in buckets filled with warm tap water. Formic acid was added until the dilution reached a concentration of about $5 \% \mathrm{HCOOH}$. The process was repeated until samples were dissolved which were dissolved by formic and acetic acid. The prevalence of siliciclastic sediments in the section produced very large insoluble residue in the $63-\mu \mathrm{m}, 125-\mu \mathrm{m}, 250-\mu \mathrm{m}$, and $500-\mu \mathrm{m}$ fractions. The fractions were dried in an oven $\left(\sim 40^{\circ} \mathrm{C}\right)$ and the most promising 
conodont sized fractions were separated by using liquid sodium polytungstate. Later, the conodonts were hand-picked under a microscope.

The light fractions were picked also for other fossil remnants, such as microvertebrates and ostracods. Microvertebrate classification was made by Dr. Brett Roelofs in Curtin University, Australia and ostracods by Prof. Atike Nazik in Cucurova University, Turkey.

The southern Mongolian Bayankhoshuu Ruins section yielded also some poor preserved radiolarians. In 2020 together with Prof. Mongkol Udchachon and Dr. Hathaithip Thassanapak thirtheen radiolarian specimens were extracted and classified in Palaeontological Research and Education Center, Mahasarakham University, Thailand.

Classification of macrofossils was performed at different institutions: crinoids were studied by Dr. Johnny Waters in Appalachian State University; brachiopods by Dr. Uli Jansen in Senckenberg-Research Institute and Natural History Museum Frankfurt; trilobites by Dr. Catherine Crônier in the University of Lile; bryozoans by Sc. Dr. Ariunchimeg Yarinpil in Natural Historical Museum of Ulaanbaatar.

Sedimentary geochemistry: Sedimentary geochemistry based on multiple analytical methods such as whole rock geochemistry, framboidal pyrite distribution performed on a JEOL JSM-IT300LV low vacuum SEM at the Appalachian State University. Geochemical analyses of specific successions are not finished while writing this report and will be published later.

\section{Structure of the PhD thesis}

In order to address the questions of global ocean anoxia and extinction e.g. at the F-F and the $\mathrm{D} / \mathrm{C}$ boundaries, and determine the trigger mechanism(s) within CAOB, this dissertation comprises 3 studies dealing with biostratigraphy and sedimentology from southwestern and southern Mongolia. Here, I provide a short introduction to the following chapters, including a brief overview about the topic.

In chapter 2, a study entitled "The Hushoot Shiveetiin gol section (Baruunhuurai Terrane, Mongolia): Sedimentology and facies from a Devonian island arc setting" by Ariuntogos Munkhjargal, Peter Königshof, Sven Hartenfels, Uli Jansen, Atike Nazik, Sarah Carmichael, Johnny Waters, Sersmaa Gonchigdorj, Catherine Crônier, Ariunchimeg Yarinpil, Olivia Paschall and Alicia Dombrowski is presented. This section is composed of Famennian to early Mississippian (most probably with the D/C boundary interval) rocks representing shallowintertidal to open marine environmental settings. In this report, we present new biostratigraphic data and new facies interpretations. Sedimentation is characterized by coeval Late Devonian volcanism.

In chapter 3, a study entitled "Late Devonian (Famennian) phacopid trilobites from western Mongolia" by Catherine Crônier, Ariuntogos Munkhjargal, Peter Königshof, Johnny Waters and Sarah Carmichael is presented. In this report, the new trilobite species Feistops mongoliensis 
gen. nov. sp. nov. and ?Houseops olonbulagensis sp. nov. from the crepida conodont Biozone, Feistops khovdensis gen. nov. sp. nov. and ?Feistops sp. A from the Palmatolepis rhomboidea conodont Biozone, are described, and biogeographic affinities are discussed. Results provide important information on the post-F/F event trilobite diversity in shallow-water.

In chapter 4, a study entitled "The Mandalovoo-Gurvansayhan terranes in the southern Gobi of Mongolia: new insights from the Bayankhoshuu Ruins section" by Ariuntogos Munkhjargal, Peter Königshof, Johnny Waters, Sarah Carmichael, Sersmaa Gonchigdorj, Mongkol Udchachon, Hathaithip Thassanapak and Sharav Davaanyam is presented. The report provides stratigraphical and sedimentological new insights from Bayankhoshuu Ruins section. Deposits of the Bayankhoshuu Ruins section suggest an island arc setting, which is characterized by complex facies setting. Coeval volcanic activity contains both, submarine volcanism as well as subaerial volcanism, ranging from Middle Devonian to Late Devonian. Due to strong faulting and thrusting, neither F/F Event not the D/C boundary were determined. Facies analysis and biostratigraphy provide profound new results, which led to the revision of some Formations/Members.

Chapter 5 summarizes the results of this thesis. Data acquired within this thesis are already published in three manuscripts. Meantime, three other papers on the Mongolian sections have been published, co-authored by A. Munkhjargal (see references).

\section{References}

Alekseeva, R.E. (1993). Devonian biostratigraphy of Mongolia. Joint Soviet-Mongolian Paleontological Expedition, 44, 33-34 [In Russian].

Aretz, M. (2021). The Late Devonian Extinctions. In: Encyclopedia of Geology (2nd Edition), Reference Module in Earth Systems and Environmental Sciences, p. 628-636.

Aretz, M., \& Corradini, C. (2021). Global review of the Devonian-Carboniferous Boundary: an introduction. Palaeobiodiversity and Palaeoenvironments, 101(2), 285-293.

Ariunchimeg, Ya., Bayasgalan, A., Waters, J.A., Kido, E., Suttner, T.J., Sersmaa, G., Undariya, J., \& Otgonbaatar, D. (2014). IGCP 596 IGCP580 Field Workshop Guidebook. 8-18th August, 2014, Ulaanbaatar, Mongolia. Paleontological Center, Mongolian Academy of Sciences, 1-55.

Badarch, G., Cunningham, W.D., \& Windley, B.F. (2002). A new subdivision for Mongolia: implications for Phanerozoic crustal growth in Central Asia. Journal of Asian Earth Sciences, 21, $87-110$.

Bambach, R.K. (2006). Phanerozoic biodiversity mass extinctions. Annual Review of Earth and Planetary Sciences, 34, 127-155. 
Bambach, R.K., Knoll, A.H., \& Wang, S.C. (2004). Origination, extinction, and mass depletions of marine diversity. Paleobiology, 30(4), 522-542.

Becker, R., \& House, M. (1994). Kellwasser Events and goniatite successions in the Devonian of the Montagne Noire with comments on possible causations. Courier Forschungsinstitut Senckenberg, 169, 45-77.

Becker, R.T., Gradstein, F.M., \& Hammer, O. (2012). The Devonian Period. In F.M. Gradstein (Ed.), The Geologic Time Scale (Vol. 2, pp. 559-601). https://doi.org/10.1016/B978-0-44459425-9.00022-6.

Becker, R.T., House, M.R., Kirchgasser, W., \& Playford, P.E. (1991). Sedimentary and faunal changes across the Frasnian/Famennian boundary in the Canning Basin of Western Australia. Historical Biology, 5(2-4), 183-196.

Bolshakova, L.N., Bondarenko, O.B., Minjin, Ch., Ulitina, L.M., \& Sharkova, T.T. (2003). Paleontology of Mongolia: corals and stromatoporoids. Nauka, Moskow, pp. 199-256, [In Russian].

Bond, D., \& Wignall, P.B. (2005). Evidence for late Devonian (Kellwasser) anoxic events in the Great Basin, western United States. Developments in Palaeontology and Stratigraphy, 20, 225262.

Bond, D., \& Wignall, P.B. (2009). The role of sea-level change and marine anoxia in the Frasnian-Famennian (Late Devonian) mass extinction. Palaeogeography, Palaeoclimatology, Palaeoecology, 263(3-4), 107-118. https://doi.org/10.1016/j.palaeo.2008.02.015.

Bond, D., Wignall, P.B., \& Racki, G. (2004). Extent and duration of marine anoxia during the Frasnian-Famennian (Late Devonian) mass extinction in Poland, Germany, Austria and France. Geological Magazine, 141(2), 173-193.

Bratton, J.F., Berry, W., \& Morrow, J. (1999). Anoxia predates Fransnian-Famennian boundary mass extinction horizon in the Great Basin, USA. Palaeogeography, Palaeoclimatology, Palaeoecology, 154, 275-292.

Brett, C., \& Baird, G.C. (1995). Coordinated stasis and evolutionary ecology of Silurian to Middle Devonian faunas in the Appalachian Basin. In D.H. Erwin, \& R.L. Anstey, (Eds.), New Approaches to Speciation in the Fossil Record. New York, Columbia University Press, 285-315.

Buggisch, W., \& Joachimski, M.M. (2006). Carbon isotope stratigraphy of the Devonian of Central and Southern Europe. Palaeogeography, Palaeoclimatology, Palaeoecology, 240(1), 6888 . 
Caplan, M., \& Bustin, R.M. (1999). Devonian-Carboniferous Hangenberg mass extinction event, widespread organic-rich mudrock and anoxia: Causes and consequences. Palaeogeography, Palaeoclimatology, Palaeoecology, 148(4), 187-207.

Carmichael, S.K., Waters, J.A., Batchelor, C.J., Coleman, D.M., Suttner, T.J., Kido, E., Moore, L.M., \& Chadimová, L. (2016). Climate instability and tipping points in the Late Devonian: Detection of the Hangenberg Event in an open oceanic island arc in the Central Asian Orogenic Belt. Gondwana Research, 32, 213-231.

Carmichael, S.K., Waters, J.A., Suttner, T.J., Kido, E., \& DeReuil, A.A. (2014). A New model for the Kellwasser Anoxia Events (Late Devonian): Shallow Water Anoxia in an Open Oceanic Setting in the Central Asian Orogenic Belt. Palaeogeography, Palaeoclimatology, Palaeoecology, 399, 394-403. https://doi:10.1016/j.palaeo.2014.02.016.

Copper, P. (1986). Frasnian/Famennian mass extinction and cold-water oceans. Geology, 14(10), 835-839.

Copper, P. (2002). Reef development at the Frasnian/Famennian mass extinction boundary. Palaeogeography, Palaeoclimatology, Palaeoecology, 181(1), 27-65.

Ernst, E.R., Rodygin, S., \& Grinev, O.M. (2019). Age correlation of Large Igneous Provinces with Devonian biotic crises. Global and Planetary Change, 185(7). https://doi.org/10.1016/j.gloplacha.2019.103097.

George, A.D., Chow, N., \& Kate, T. (2014). Oxic facies and the Late Devonian mass extinction, Canning Basin, Australia. Geology, 42(4), 327-330. https://doi.org/10.1130/G35249.1.

Hallam, A., \& Wignall, P.B. (1999). Mass extinctions and sea-level changes. Earth-Science Reviews, 48, 217-250. https://doi.org/10.1016/S0012-8252(99)00055-0.

House, M.R. (1985). Correlation of mid-Palaeozoic ammonoid evolutionary events with global sedimentary perturbations. Nature, 313(5997), 17-22.

Huang, C., Joachimski, M.M., \& Gong, Y. (2018). Did climate changes trigger the Late Devonian Kellwasser Crisis? Evidence from a high-resolution conodont $818 \mathrm{OPO} 4$ record from South China. Earth and Planetary Science Letters, 495, 174-184.

Izokh, O., Izokh, N., Ponomarchuk, V., \& Semenova, D. (2009). Carbon and oxygen isotopes in the Frasnian-Famennian section of the Kuznetsk Basin (southern West Siberia). Russian Geology and Geophysics, 50(7), 610-617.

Joachimski, M.M., \& Buggisch, W. (2002). Carbon isotope geochemistry of the FrasnianFamennian transition. Palaeogeography, Palaeoclimatology, Palaeoecology, 181, 91-109. 
Joachimski, M.M, \& Buggisch, W. (1993). Anoxic events in the late Frasnian-Causes of the Frasnian-Famennian faunal crisis? Geology, 21, 675-678. https://doi.org/10.1130/00917613(1993)021<0675:AEITLF>2.3.CO;2.

Kaiser, S.I., Aretz, M., \& Becker, R.T. (2015). The global Hangenberg Crisis (DevonianCarboniferous transition): review of a first-order mass extinction. In R.T. Becker, P. Königshof, \& C.E. Brett, (Eds.), Devonian Climate, Sea Level and Evolutionary Events. Geological Society, Special Publication, 423, 387-437. https://doi.org/10.1144/SP423.9.

Kido, E., Suttner, T.J., Johnny, W.A., Ariunchimeg, Ya., Sersmaa, G., James, W.A., \& Gary, D.W. (2013). Devonian deposits of the Baruunhuurai Terrane, western Mongolia (IGCP 596 Field Workshop) The Middle and Late Devonian in the Junggar Basin. Episodes, 36(4), 242254.

Komatsu, T., Kato, S., Hirata, K., Takashima, R., Orata, Y., Oba, M., Naruse, H., Tha Hoa P., Nguyen, P.D., Dang, H.T., Nguyen, H.H., Kaiho, K., Sakata, S., \& Königshof, P. (2014). Devonian-Carboniferous transition containing a Hangenberg Black Shale equivalent in the Pho Han Formation on Cat Ba Island, northeastern Vietnam. Palaeogeography, Palaeoclimatology, Palaeoecology, 404, 30-43. https://doi:10.1016/j.palaeo.2014.03.021.

Königshof, P., Bahrami, A., \& Kaiser, S.I. (2021). Devonian-carboniferous boundary sections in Iran. In M. Aretz, \& C. Corradini, (Eds.), Global review of the Devonian-Carboniferous Boundary. Palaeobiodiversity and Palaeoenvironments, 101(2), 613-632.

Königshof, P., Carmichael, S., Waters, J., Jansen, U., Bahrami, A., Boncheva, I., \& Yazdi, M. (2017a). Paleoenvironmental study of the Paleotethys Ocean: The Givetian/Frasnian boundary of a shallow-marine environment using combined facies analysis and geochemistry (Zefreh Section/Central Iran). In B. Mottequin, L. Slavik, \& P. Königshof, (Eds.), Climate change and biodiversity patterns in the mid-Palaeozoic-Proceedings-Volume IGCP 596/SDS Meeting Brussels (2015). Palaeobiodiversity and Palaeoenvironments, 97(3), 517-540. http://www.doi.10.1007/s12549-016-0253-0.

Königshof, P., Da Silva, A.C., Suttner, T.J., Kido, E., Waters, J.A., Carmichael, S.K., Jansen, U., Pas, D., \& Spassov, S. (2016). Shallow water facies setting around the Kacak Event-a multidisciplinary approach. In R.T. Becker, P. Königshof, \& C.E. Brett, (Eds.), Devonian Climate, Sea Level and Evolutionary Events. Geological Society London, Special Publication, 423, 171-199. https://doi:10.1144/SP423.4.

Königshof, P., Narkiewicz, K., Phuong, Ta Hoa, Carmichael, S., \& Waters, J. (2017b). Events in the mid-Paleozoic: Examples from the eastern Paleotethys (Si Phai section, NE Vietnam). In B. Mottequin, L. Slavik, \& P. Königshof, (Eds.), Climate change and biodiversity patterns in the mid-Palaeozoic-Proceedings-Volume IGCP 596/SDS Meeting Brussels (2015). 
Palaeobiodiversity and Palaeoenvironments, 97(3), 481-496. https://doi:10.1007/s12549-017$\underline{0272-5}$.

Königshof, P., Savage, N., Lutat, P., Sardsud, A., Dopieralska, J., Belka, Z., \& Racki, G. (2012). Late Devonian sedimentary record of the Palaeotethys Ocean-The Mae Sariang succession, northwestern Thailand. Journal Asian Earth Sciences, 52, 146-157. https://doi.10.1016/j.jseaes.2012.03.006.

Lamb, M.A., \& Badarch, G. (2001). Paleozoic sedimentary basins and volcanic arc systems of southern Mongolia: New geochemical and petrographic constraints. In M.S. Hendrix, \& G.A. David, (Eds.), Paleozoic and Mesozoic Tectonic Evolution of Central and Eastern Asia: From Continental Assembly to Intracontinental Deformation. Memoir of the Geological Society of America, 194, 117-149.

Lenton, T.M., Daines, S.J., \& Mills, B.J.W. (2018). COPSE reloaded: an improved model of biogeochemical cycling over Phanerozoic time. Earth-Science Reviews, 178, 1-29. https://doi.org/10.1016/j.earscirev.2017.12.004.

Liu, Y., Liu, J., \& Neubauer, F. (2017). Deformation and rheology of the Asian continent. Journal of Asian Earth Sciences, 139, 1-5.

McGhee, G.R., Clapham, M.E., Sheehan, P.M., Bottjer, D.J., \& Droser, M.L. (2013). A new ecological-severity ranking of major Phanerozoic biodiversity crises. Palaeogeography, Palaeoclimatology, Palaeoecology, 370, 260-270.

McGhee, G.R., Sheehan, P.M., Bottjer, D.J., \& Droser, M.L. (2012). Ecological ranking of Phanerozoic biodiversity crises: The Serpukhovian (early Carboniferous) crisis had a greater ecological impact than the end-Ordovician. Geology, 40(2), 147-150.

McLaren, D.J. (1970). Presidential address: time, life and boundaries. Journal of Paleontology, $44,801$.

McLaren, D.J., \& Goodfellow, W.D. (1990). Geological and biological consequences of giant impacts. Annual Review of Earth Planet Science, 18, 123.

Minjin, Ch., \& Tumenbayar, B. (2001). The guidebook, abstract \& Ordovician Silurian correlation chart for the joint field meeting of IGCP 410 and IGCP 421.

Newell, N.D. (1967). Revolutions in the history of life. Geological Society of America, 89, 6391.

Paschall, O.C., Carmichael, S.K., Königshof, P., Waters, J.A., Joachimski, M.M., P.H. Ta., \& Komatsu, T. (2019). The Hangenberg Event in Vietnam: sustained ocean anoxia with a volcanic trigger? Global and Planetary Change, 175, 64-81. 
Purdy, E.G. (2008). Comparison of taxonomic diversity, strontium isotope and sea-level patterns. International Journal of Earth Sciences, 97, 651-664. https://doi.org/10.1007/s00531-007-0177$\underline{\mathrm{z}}$.

Racki, G., \& Wignall, P. (2020). Devonian global changes-Recent advances and challenges in different domains. Global and Planetary Change, 191. https://doi.org/10.1016/j.gloplacha.2020.103200.

Racki, G., Königshof, P., Bełka, Z., Dopieralska, J., \& Pisarzowska, A. (2019). Diverse geochemical signature of the Frasnian-Famennian global event in the western Thailand, as the record of Palaeotethyan vs. Western Australian geotectonic affinities. Journal of Asian Earth Sciences, 2, 117-149. https://doi.org/10.1016/j.jaesx.2019.100010.

Racki, G., Rakociński, M., \& Marynowski, L. (2018). Anomalous Upper Devonian mercury enrichments: Comparison of inductively coupled plasma-mass spectrometry (ICPMS) and AAS analytical data. Geology Quarterly, 62(3), 487-495. https://doi.org/10.7306/gq.1419.

Raup, D.M., \& Sepkoski, J.J. (1982). Mass extinctions in the marine fossil record. Science, 215, $1501-1503$.

Ruban, D.A. (2010). Do new reconstructions clarify the relationships between the Phanerozoic diversity dynamics of marine invertebrates and long term eustatic trends? Annales de Paléontologie, 96, 51-59. https://doi.org/10.1016/j.annpal.2010.08.001.

Ruban, D.A. (2013). The late Silurian-Middle Devonian long-term eustatic cycle as a possible control on the global generic diversity dynamics of bivalves and gastropods. Geologos, 19, 193200. https://doi.org/10.2478/logos-2013-0012.

Safonova, I., Kotlyarov, A., Krivonogov, S., \& Xiao, W. (2017). Intraoceanic arcs of the PaleoAsian Ocean. Gondwana Research, 50, 167-194. https://doi.org/10.1016/j.gr.2017.04.005.

Sepkoski, J.J. (1996). Patterns of Phanerozoic extinction: a perspective from global databases. In O.H. Walliser (Ed.), Global events and event stratigraphy in the Phanerozoic (pp. 35-51). Berlin: Springer-Verlag. https://doi.org/10.1007/978-3-642-79634-0_4.

Shizuya, A., Oba, M., Ando, T., Ogata, Yu., Takashima, R., Nishi, H., Komatsu, T., \& Nguyen, P.D. (2019). Variations in trace elements, isotopes, and organic geochemistry during the Hangenberg Crisis, Devonian-Carboniferous transition, northeastern Vietnam. Island Arc 29(1), 1-20. https://doi.org/10.1111/iar.12337.

Schobben, M., Stebbins, A., Ghaderi, A., Strauss, H., Korn, D., \& Korte, C. (2016). Eutrophication, microbial-sulfate reduction and mass extinctions. Communicative \& Integrative Biology, 9(1), 1-25. https://doi.org/10.1080/19420889.2015.1115162. 
Smith, A.B., \& Benson, R.B.J. (2013). Marine diversity in the geological record and its relationship to surviving bedrock area, lithofacies diversity, and original marine shelf area. Geology, 41, 171-174. https://doi.org/10.1130/G33773.1.

Song, H.J., Algeo, T.J., Tong, J.N., Romaniello, S.J., Zhu, Y.Y., Chu, D.L., \& Anbar, A.D. (2017). Uranium and carbon isotopes document global-ocean redox-productivity relationships linked to cooling during the Frasnian-Fammenian mass extinction. Geology, 45, 887-890. https://doi.org/10.1130/G39393.1.

Spalletta, C., Perri, M.C., Over, D.J., \& Corradini, C. (2017). Famennian (Upper Devonian) conodont zonation: revised global standard. Bulletin of Geosciences, 91, 31-57. https://doi.org/10.3140/bull.geosci.1623.

Suetenko, O.D., Sharkova, T.T., \& Ulitina, K.M. (1977). Paleozoic stratigraphy and fauna of the eastern spurs of Gobian Altai (Mandal-Ovoo massif). Transactions Joint Soviet-Mongolian Paleontological Expedition, 5, 32-48 [In Russian].

Suttner, T.J., Kido, E., Ariunchimeg, Ya., Sersmaa, G., Waters, J.A., Carmichael, S.K., Batchelor, C.J., Ariuntogos, M., Hušková, A., Slavík, L., Valenzuela-Ríos, J.I., Liao, J.-C., \& Gatovsky, Y.A. (2020). Conodonts from Late Devonian island arc settings (Baruunhuurai Terrane, western Mongolia). Palaeogeography, Palaeoclimatology, Palaeoecology, 549, 1-22. https://doi.org/10.1016/j.palaeo.2019.03.001.

Tolokonnikova, Z.A., \& Ernst, A. (2010). Palaeobiogeography of Famennian (Late Devonian) bryozoans. Palaeogeography Palaeoclimatology Palaeoecology, 298(3-4), 360-369.

Walliser, O.H. (1996). Global Events and Event Stratigraphy (pp. 225-250). Springer-Verlag, Berlin,

Waters, J.A., \& Webster, G.D. (2009). A re-evaluation of Famennian echinoderm diversity: Implications for patterns of extinction and rebound in the Late Devonian. Geological Society London Special Publications, 314(1), 149-161.

Xiao, W., \& Santosh, M. (2014). The western Central Asian orogenic belt: A window to accretionary orogenesis and continental growth. Gondwana Research, 25(4), 1429-1444. https://doi.org/10.1016/j.gr.2014.01.008.

Zhang, M., Becker, R.T., Ma, X., Zhang, Y., \& Zong, P. (2018) Hangenberg Black Shale with cymaclymeniid ammonoids in the terminal Devonian of South China. Palaeobiodiversity and Palaeoenvironments, 99, 129-142. https://doi.org/10.1007/s12549-018-0348-x. 
Chapter 2 - The Hushoot Shiveetiin gol section (Baruunhuurai Terrane, Mongolia): Sedimentology and facies from a Devonian island arc setting

Munkhjargal, A. ${ }^{1,2}$, Königshof, P. ${ }^{2}$, Hartenfels, S. ${ }^{3}$, Jansen, U. ${ }^{2}$, Nazik, A. ${ }^{4}$, Carmichael, S.K. ${ }^{5}$, Waters, J.A. ${ }^{5}$, Sersmaa, G. ${ }^{1}$, Crônier, C. ${ }^{6}$, Ariunchimeg, Ya. ${ }^{7}$, Paschall, O. ${ }^{5}$, Dombrowski, A. ${ }^{5}$

(1) Mongolian University of Science and Technology, Baga toiruu, Sukhbaatar District, Ulaanbaatar, Mongolia.

(2) Senckenberg Research Institute and Natural History Museum, Senckenberganlage 25, 60325 Frankfurt, Germany.

http://orcid.org/0000-0001-5300-8469.

(3) University of Cologne, Institute of Geology and Mineralogy, Zülpicher Str. 49a, 50674

Cologne, Germany.

(4) Cukurova University Faculty of Engineering Department, Mithat Özsan Bulvari TR-01330 Adana, Turkey.

(5) Department of Geological and Environmental Sciences, Appalachian State University, 572 Rivers St., Boone, NC 28608, USA.

(6) Université de Lille, CNRS, UMR 8198 Évo-Éco-Paléo, F-59000 Lille, France.

(7) Institute of Paleontology and Geology, Mongolian Academy of Sciences, P.O. Box 46/52, Ulaanbaatar 14201, Mongolia.

Published in Palaeobiodiversity and Palaeoenvironments, Received: 29 April 2020 /Revised: 26 June 2020 /Accepted: 21 July 2020, https://doi.org/10.1007/s12549-020-00445-0.

\section{Abstract}

An Upper Devonian to (?)Lower Mississippian section at Hushoot Shiveetiin gol in the Baruunhuurai Terrane of the Central Asian Orogenic Belt (CAOB) exposes large parts of cyclic Famennian shallow-water siliciclastic shelf deposits composed of siltstones, sandstones, shales, volcaniclastics, and intercalated autochthonous carbonates. The youngest part of the section, possibly Lower Mississippian, is represented by arkosic sandstones with large plant remains. The facies reflects a range from shallow-intertidal to outer ramp settings. In terms of conodont stratigraphy the Hushoot Shiveetiin gol section ranges from the Palmatolepis minuta minuta Zone to at least the Palmatolepis rugosa trachytera Zone. Hiatuses of several conodont zones occur due to the facies setting (erosion and reworked sediments, which are recognized by reworked conodonts) rather than thrusting or folding. The environmental setting was characterized by coeval subaerial volcanism, resulting in numerous pyroclastic deposits. The depositional environments and intense volcanic activity at the Hushoot Shiveetiin gol section limited the stratigraphic distribution, abundance and diversity of many elements of the fauna such as brachiopods. Ostracods were very abundant and diverse through many parts of the section. Although limited in stratigraphic distribution, the crinoid fauna is the most diverse Palaeozoic fauna collected from Mongolia to date, and supports the hypothesis that the CAOB was a biodiversity hotspot in the aftermath of the Frasnian-Famennian extinction.

Keywords: Central Asian Orogenic Belt (CAOB), Facies, Biostratigraphy, Volcanism, Biodiversity hotspot, Hangenberg Crisis 


\section{Introduction}

The global atmospheric $\mathrm{CO}^{2}$ and climate significantly changed during the mid-Palaeozoic, especially in the Late Devonian (Algeo and Scheckler 1998; Stein et al. 2007; Becker et al. 2016) and coincided with major extinction events. The most severe anoxic intervals have been documented within the Kellwasser events near the Frasnian/Famennian (F/F) boundary, the Annulata events in the Famennian, and the Hangenberg Event near the Famennian/Tournasian (D/C) stage boundary (Sepkoski 1996; Racki 2005; Hartenfels 2011; Kaiser et al. 2015; Hartenfels and Becker 2016; Bond \& Graspy 2017). But studies on events in the Late Devonian, particularly the F/F boundary, primarily are focused on hemipelagic and pelagic settings (see review article by Carmichael et al. 2019) with relatively few studies dealing with shallow-water sections. The disparity of information in different depositional settings and areas fundamentally hampers knowledge on climate change and faunal change during and in the aftermath of global extinction events. As a step towards addressing problems of palaeogeographic sample bias, biostratigraphy, biodiversity change in the aftermath of the F/F Event, we present results of a Famennian to (?)Lower Mississippian section that ranges from shallow-subtidal to outer ramp settings within the Central Asian Orogenic Belt (CAOB).

Studies from the $\mathrm{CAOB}$ and neighbouring regions reported high Famennian diversity from different fossil groups (Ariunchimeg et al. 2014; Zong et al. 2015; Song et al. 2017). Furthermore, bryozoans and crinoids expanding from shallow-water refugia support the idea of the CAOB as a biodiversity hotspot (Waters et al. 2003; Webster and Waters 2009; Ernst 2013). Recent fieldwork in the Upper Devonian deposits from the CAOB within western Mongolia (Kido et al. 2013; Ariunchimeg et al. 2014; Suttner et al. 2019) and analogous sites in NW-China (Suttner et al. 2014; Carmichael et al. 2014, 2016; Stachacz, in press; Wang et al. 2016; Song et al. 2019) suggest that the Hushoot Shiveetiin gol site in the Baruunhuurai Terrane in western Mongolia (which represents a shallow-water/neritic palaeoenvironment) is likewise essential for understanding biodiversity patterns in isolated ecosystems in the aftermath of the F/F event.

\section{Geological setting}

The CAOB covers a huge area which extends from Kazakhstan in the west, through Kyrgyzstan, Uzbekistan, northwestern China, the Altai-Sayan region, and Transbaikalia in Russia, Mongolia, and northeastern China to the Russian Far East and includes oceanic, intraoceanic, and numerous fragments of Precambrian microcontinents and collisional and postcollisional complexes as well as continental margin arc terranes (Xiao et al. 2010; Xiao and Santosh 2014; Yang et al. 2019). This accretionary system has evolved across at least 800 myr, from the Neoproterozoic time until the Cenozoic (Safonova et al. 2017). The complicated Palaeozoic association was formed prior to the end of the Carboniferous (Xiao et al. 2010; Metcalfe 2011; Choulet et al. 2012; Yang et al. 2013a, b; Li et al. 2017). According to Windley et al. (2007), Donskaya et al. (2013), and Yang et al. (2015), the subduction of the Palaeo-Asian Ocean continued during the mid- and late Palaeozoic before the final closure of this ocean and its 
Turkestan and Junggar branches during the late Palaeozoic to the Mesozoic (Safonova et al. 2017). The Palaeozoic rocks of western Mongolia described in this paper are part of the complex tectonic framework of the CAOB.

Deposits of the Baruunhuurai Terrane have a stratigraphic range from Devonian to Carboniferous and are located in the southwestern part of Mongolia close to the border to China (Badarch et al. 1998). According to earlier studies, the Baruunhuurai Terrane is subdivided into Baaran, Ulaan-Us, and Baitag, Olonbulag subterranes (Badarch et al. 1998; Dergunov 2001). The Baaran and Olonbulag subterranes represent an Andean type active continental margin that was formed on the eastern continuation of the Caledonian Chingis Tarbagatai continent (Ruzhentsev et al. 1992). Similar tectonic structures occur in eastern Kazakhstan and northwestern China, and the two proposed subterranes are analogs of the Central Kazakhstan volcanic belt. More recent studies by Tumurtogoo (2014) subdivide the Baruunhuurai Terrane into three rather than four subterranes (for a more detailed discussion on that plate tectonics, we refer to Safonova et al. 2017; an overview and description of each formation and fossil content are provided by Ariunchimeg et al. 2014).

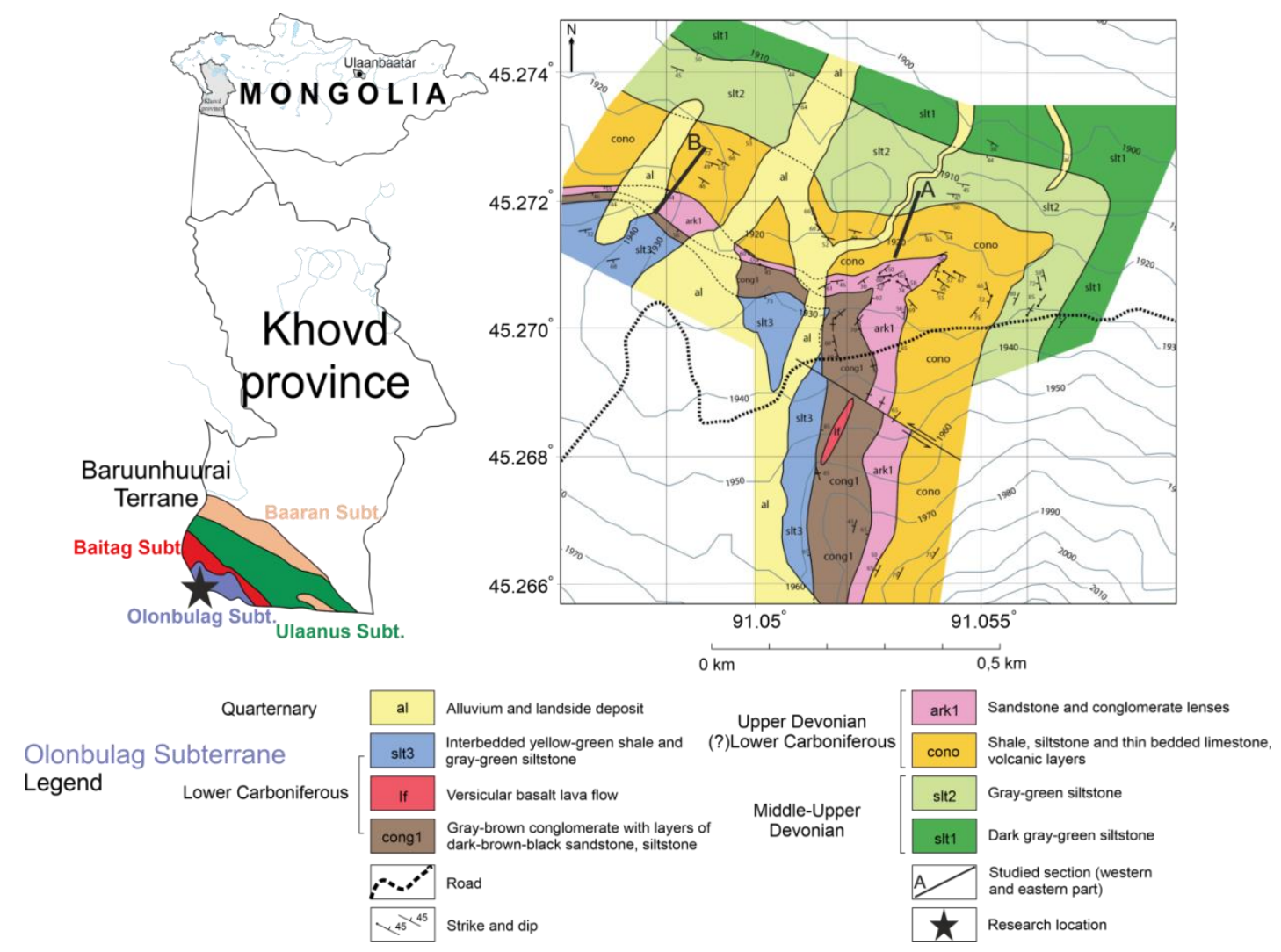

Fig. 1 Geological map of the Hushoot Shiveetiin gol section, eastern part (A) and western part (B), based on new mapping data during fieldwork in 2018.

The investigated section is located in the Olonbulag Subterrane (Fig. 1) and ranges from the Famennian to (?)Mississippian. The exposed Upper Devonian and (?)Lower Mississippian 
sedimentary rocks belong to the Samnuuruul Formation which has a thickness of $250-450 \mathrm{~m}$. The Samnuuruul Formation was classified for the first time during regional geological mapping (Lazarev and Suurisuren 1992). Rocks of the Samnuuruul Formation conformably lie above Middle Devonian rocks of the Khurendush Formation.

The section is primarily composed of siliciclastic rocks, including volcaniclastic deposits. Limestones occur in a limited number of thin-bedded layers containing various fossils, such as corals, bryozoans, brachiopods, and conodonts, which support a Famennian age (see earlier studies by Bolshakova et al. 2003; Kido et al. 2013; Ariunchimeg et al. 2014; Suttner et al. 2020). The uppermost part of the Samnuuruul Formation consists of a series of arkosic sandstones, and conglomeratic sandstones with plant fossils, which most probably are (?)Early Mississippian in age.

\section{Materials and methods}

Forty-five samples between 1 and $4 \mathrm{~kg}$ were collected for biostratigraphic analysis from the eastern and western Hushoot Shiveetiin gol section (description of two sections are a result of different field campaigns) in order to enhance the stratigraphic record published by Suttner et al. (2020). Limestones and marls were cleaned and crushed to about $2 \mathrm{~cm} 3$ and placed in widemesh sieves hung in buckets filled with warm tap water. Formic acid was added until the dilution reached a concentration of about $5 \% \mathrm{HCOOH}$. The process was repeated until samples were dissolved. Ninety samples for conodont biostratigraphy were processed (about $93 \mathrm{~kg}$ ). The prevalence of siliciclastic sediments in the section produced very large volumes of insoluble residue in the $63-\mu \mathrm{m}, 125-\mu \mathrm{m}, 250-\mu \mathrm{m}$, and $500-\mu \mathrm{m}$ fractions. The fractions were dried in an oven $\left(\sim 40{ }^{\circ} \mathrm{C}\right)$ and the most promising conodont sized fractions were separated by using liquid sodium polytungstate. Later, the conodonts were hand-picked under a microscope. The light fractions were picked for other fossil remnants, such as microvertebrates and ostracods. Conodonts were found in a limited number of samples, but the majority of samples were barren. Nevertheless, based on new conodont data, we could improve the biostratigraphy. As it is common practice in high-resolution stratigraphic conodont studies, only $\mathrm{Pa}$ elements were identified, as many Upper Devonian to Mississippian multi element reconstructions are still doubtful and incomplete. All conodont samples are stored at the Research Center for Stratigraphy and Paleontology in Mongolian University of Sciences and Technology, Ulaanbaatar, Mongolia, under repository numbers MUST-RCSP-CON. 0001 to 0040. Ostracods and microvertebrates are frequent in the light fractions, and thus results will be published separately.

All units were measured bed by bed at $\mathrm{cm}$ scale, and 58 rock samples were taken for microfacies analysis producing more than 100 thin sections. In order to get a thorough overview of the facies, we mainly used thin sections of 7.5 to $11 \mathrm{~cm}$ in size. The description of sandstones follows the classification published in Folk (1954), Pettijohn et al. (1973), and Tucker (2001), and is typically determined microscopically by identifying mineral composition by 300 equally 
spaced points across thin section. The samples were taken from all intervals of different facies. Facies and microfacies types (FT) were mainly compared on the basis of the classical models provided by Wilson (1975) and Flügel (2004). Thin sections are stored at the Senckenberg Research Institute and Natural History Museum Frankfurt, Germany, under repository numbers SMF 99299 to SMF 99349. Selected samples were analyzed for mineral content using a Shimadzu 6000 X-ray diffraction system and Match! identification software at Appalachian State University. Mineral identification was confirmed using scanning electron microscopy with energy-dispersive Xray spectroscopy (SEM-EDS) on a JEOL JSM-IT-300LV scanning electron microscope at $25 \mathrm{kV}$ with an Oxford AZtecEnergy integrated silicon drift energy-dispersive Xray spectroscopy (EDS) system at Appalachian State University. Whole rock geochemical analyses were performed at Activation Laboratories in Ancaster, ON, using the Total IDENT 4EResearch analytical package.

\section{Results}

\subsection{Conodont biostratigraphy}

According to conodont stratigraphy, the Hushoot Shiveetiin gol section ranges from the Palmatolepis minuta minuta Biozone to at least the Palmatolepis rugosa trachytera Biozone (Fig. 2; zonation scheme follows Hartenfels 2011 and Spalletta et al. 2017). Since conodonts are scarce in siliciclastic settings, the precise age of those sediments may not be fully determinable based on conodonts only. Stratigraphic hiatuses of several conodont biozones (Palmatolepis termini, Palmatolepis marginifera marginifera, Palmatolepis marginifera utahensis, and Scaphignathus velifer velifer biozones) occur in the section because of the scarcity of index taxa and are shown in grey color in the lithological columns (see Figs. 6 and 7). As there is no evidence of thrusting in the field, we assume that this is a continuous section at least until the top of the Unit VII. The biostratigraphic hiatuses (according to the conodont record) are believed to be a result of facies (shallow-water siliciclastics); carbonates are limited to a number of single layers. Similar problems in conodont record are known from other shallow water sections, as shown for instance by Bahrami et al. (2018, 2019) and Königshof et al. (2020). Nevertheless, we could confirm the conodont data in the lower part (eastern section) published by Suttner et al. (2020) and improve the biostratigraphy for the entire section (Figure 3). Now seven conodont biozones were indicated by either the first occurrence (FO) or the presence of some distinct taxa. In order to avoid doubling of already published data by Suttner et al. (2020), we mainly figure new taxa and taxa found in the western section. The conodont biozones of the Hushoot Shiveetiin gol section are as follows:

(a) Palmatolepis minuta minuta Biozone: based on the presence of Palmatolepis minuta minuta in sample HS-cono-16 (Suttner et al. 2020)

(b) Palmatolepis crepida Biozone: based on the presence of Polygnathus nodocostatus nodocostatus in sample HS-cono-14 (Suttner et al. 2020) 
(c) Palmatolepis glabra prima Biozone: based on FO of Palmatolepis glabra prima in sample HS-cono-10

(d) Palmatolepis glabra pectinata Biozone: based on FO of Palmatolepis glabra pectinata M2 in sample HS-C-6c

(e) Palmatolepis rhomboidea Biozone: based on FO of Palmatolepis rhomboidea in sample HS-cono-3 (Suttner et al. 2020)

(f) Palmatolepis gracilis gracilis Biozone: based on FO of Palmatolepis gracilis gracilis in sample HS-C-W15

(g) Palmatolepis rugosa trachytera Biozone: based on FO of Palmatolepis rugosa trachytera in sample HS-C-W2

Conodonts in general are not very well-preserved. Many conodonts are broken, some species show abrasion features as a result of sediment transport, and sediment is often attached to the surfaces of elements. Conodont color alteration (CAI, Epstein et al. 1977) has a range between 3 and 4 .

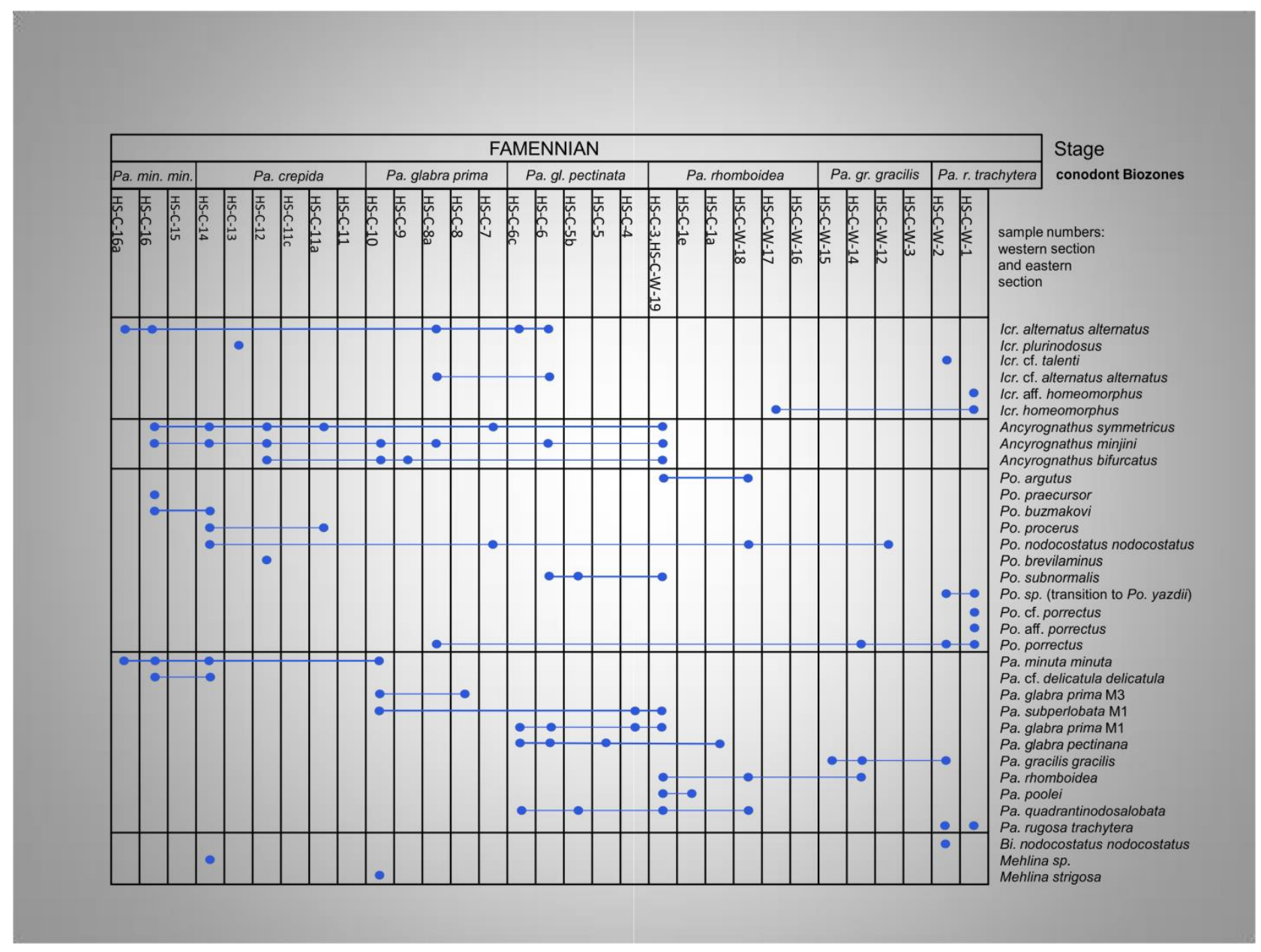

Fig. 2 Conodont distribution chart of Famennian deposits at the Hushoot Shiveetiin gol section. Data compiled from Suttner et al. (2020) and data from fieldwork in 2018 presented herein. Zonation scheme follows Spalletta et al. (2017). 
Although carbonate samples of 1 to $4 \mathrm{~kg}$ per sample were dissolved for biostratigraphic analysis, the overall number of conodont elements is relatively low. Even so, the high diversity of polygnathid species during the Palmatolepis crepida Biozone and of palmatolepids during the Palmatolepis rhomboidea Biozone recognized by Suttner et al. (2020) can be confirmed in this study. Conodont taxa are dominated by polygnathid-palmatolepid associations, whereas species of Icriodus, Ancyrognathus and Mehlina occur in a subordinate number.

The Palmatolepis rugosa trachytera Biozone, which is the youngest zone in our succession, is defined by the first occurrence of the name-giving taxon in sample HS-C-W2. Polygnathus porrectus (see Fig. 4: 6-8) occurs in this sample as well as in the next younger sample (sample HS-C-W1). Our results support the proposed stratigraphical range by Barskov et al. (1991) who suggested a range from the rhomboidea to the trachytera biozones (zonal scheme of Ziegler and Sandberg 1984). Due to the facies setting (see below), some conodonts were reworked. Icriodus homeomorphus (Fig. 4:14) occurs in samples HS-C-W1 (Palmatolepis rugosa trachytera Biozone) and an incomplete form was found in HS-C-W17 (Palmatolepis rhomboidea Biozone). In both biozones, this taxon normally does not occur. According to Mawson in Talent and Mawson (1999), it cannot be older than Late triangularis (= Palmatolepis minuta minuta, Spalletta et al. 2017) Biozone and occurs with Icriodus alternatus mawsonae in KUR 21 and 22, a form argued by Yazdi (1999) to range from Late triangularis Biozone to Early crepida (= Palmatolepis crepida, Spalletta et al. 2017) Biozone. Also, other species have been reworked such as Palmatolepis delicatula platys which were found in sample HS-C-4. Polygnathus sp. occurs in the uppermost part of the section in sample HS-C-W1. This species shows an affinity to Polygnathus yazdii based on the inner platform half. In sample HS-C-W2, an Icriodus species was found which looks like Icriodus talenti. Based on the limited number of specimens, we describe that as Icriodus cf. talenti. Ashouri (2006) described this species from the postera zones. However, Wang et al. (2016) described specimens from the local Polygnathus pomeranicus Biozone to basal Polygnathus pseudocommunis Biozone (= roughly Palmatolepis glabra pectinata to Palmatolepis marginifera marginifera biozones) from the Wulankeshun section, (Junggar Basin, China). It seems that this species has a long stratigraphical range but further research is necessary. In the uppermost part of the section, no conodonts were found due to unsuitable facies (siltstones, sandstones, conglomerates). 

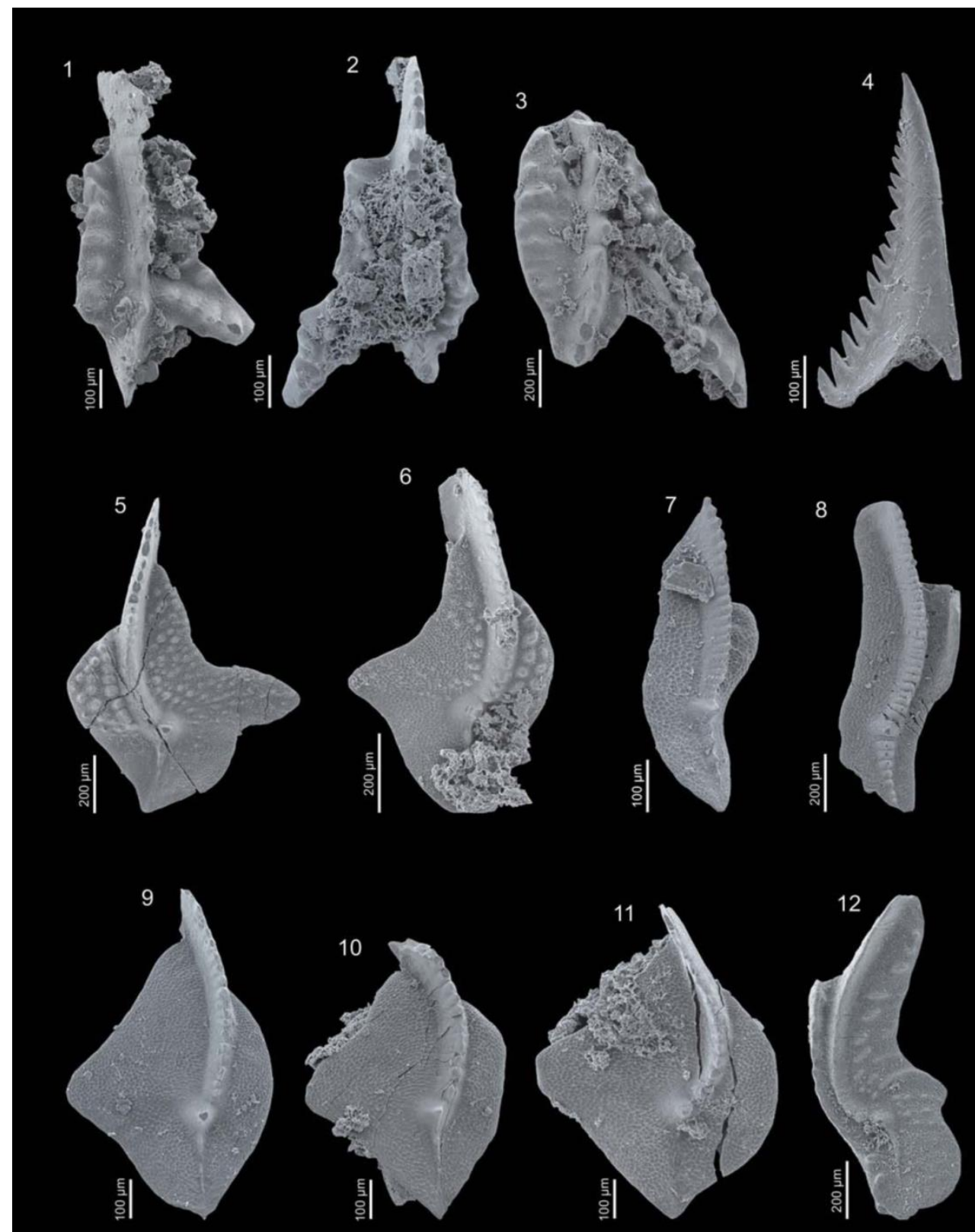

Fig. 3 Important conodonts from the Hushoot Shiveetiin gol section (collection numbers in brackets). 1: Ancyrognathus symmetricus, sample HS-C-W-19, oral view (MUST-RCSP-CON. 0003); 2: Ancyrognathus minjini, sample HS-C-3, oral view (MUST-RCSP-CON. 0004); 3: Ancyrognathus bifurcatus, sample HS-C-9, oral view (MUST-RCSP-CON. 0012); 4: Caenodontus sp., sample HS-C-6c (MUST-RCSP-CON. 0033); 5: Palmatolepis cf. quadrantinodosalobata (atypical morphotype) sample HS-C-6c, upper view (MUST-RCSP-CON. 0034); 6: Palmatolepis quadrantinodosalobata sample HS-C-W-18, upper view (MUST-RCSP-CON. 0021); 7: Palmatolepis glabra prima M3, sample HS-C-10, upper view (MUST-RCSP-CON. 0014); 8: Palmatolepis glabra pectinata M2, sample HS-C-6c, upper view (MUST-RCSP-CON. 0020); 9: Palmatolepis sp., transitional form between Palmatolepis subperlobata and Palmatolepis delicatula delicatula, sample HS-C-W19, reworked conodont, upper view (MUST-RCSP-CON. 0035); 10: Palmatolepis delicatula platys, reworked conodont, sample HS-C-W4, upper view (MUST-RCSP-CON. 0036); 11: Palmatolepis delicatula platys, reworked conodont, sample HS-C-W18 (MUST-RCSP-CON. 0023); 12: Palmatolepis rugosa trachytera, sample HS-C-W-2, upper view (MUST-RCSPCON. 0028). 


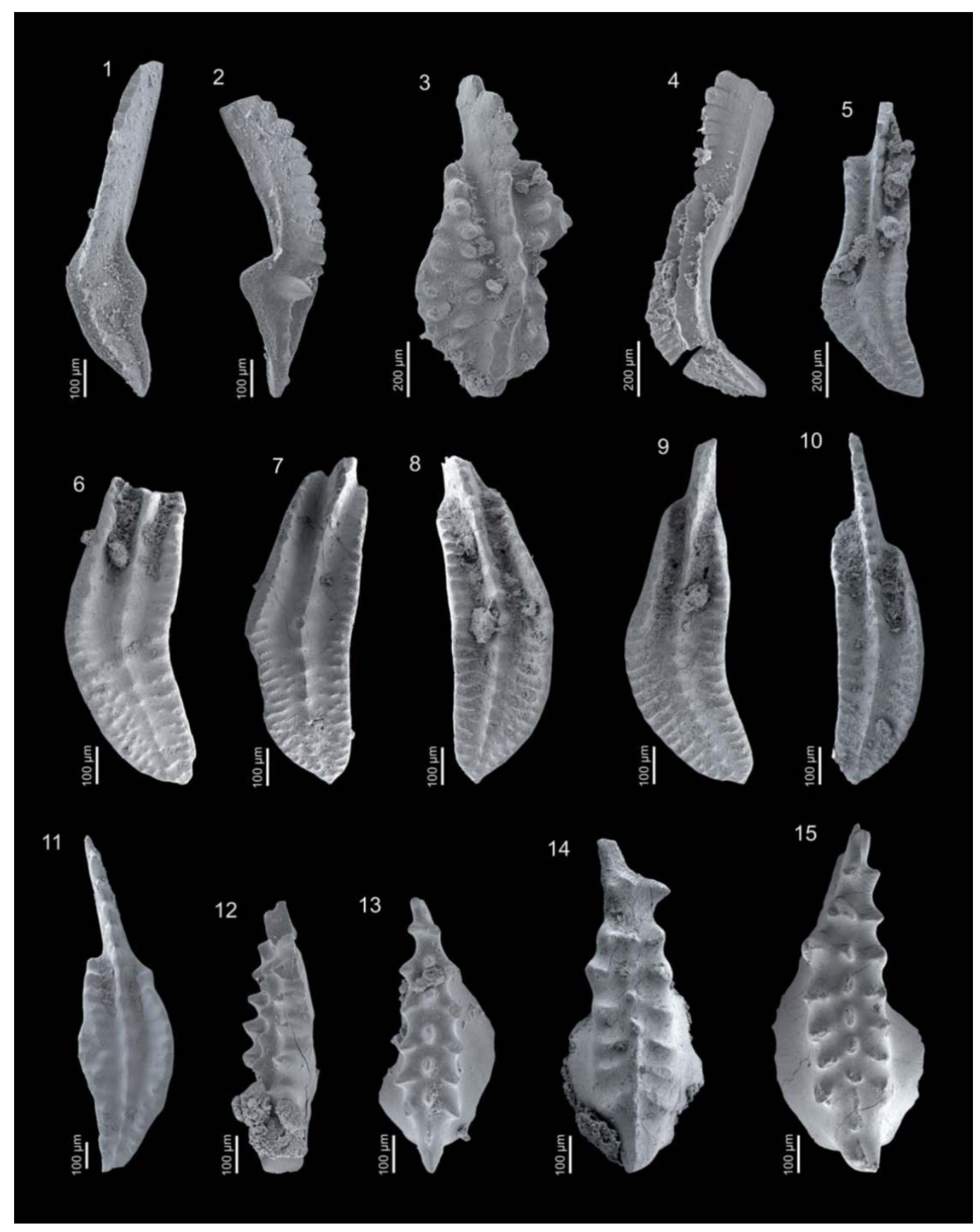

Fig. 4 Important conodonts from the Hushoot Shiveetiin gol section. 1: Palmatolepis gracilis gracilis, sample HS-CW-15, upper view (MUST-RCSP-CON. 0026); 2: Palmatolepis gracilis gracilis, sample HS-C-W2, upper view (MUST-RCSP-CON. 0026); 3: Ancyrognathus sp. Sample HS-C-5b (MUST-RCSP-CON. 0037); 4: Polygnathus subnormalis, broken specimen, sample HS-C-6 (MUST-RCSP-CON. 0022); 5: Polygnathus argutus, sample HS-CW19 upper view (MUST-RCSP-CON. 0038); 6, 7, 8: Polygnathus porrectus, sample HS-C-W1, upper view (MUST-RCSP-CON. 0018); 9: Polygnathus cf. porrectus, sample HS-C-W1, upper view (MUST-RCSP-CON. 0031); 10: Polygnathus aff. porrectus, sample HS-C-W1, upper view (MUST-RCSP-CON. 0032); 11: Polygnathus sp., sample HS-C-W1, upper view (MUST-RCSP-CON. 0027); 12: Icriodus cf. alternatus alternatus, sample HS-C6 (MUST-RCSP-CON. 0017); 13: Icriodus cf. talenti, sample HS-C-W2 (MUST-RCSP-CON. 0001); 14: Icriodus homeomorphus, sample HS-C-W1, upper view, reworked conodont (MUST-RCSP-CON. 0025); 15: Icriodus aff. homeomorphus, sample HS-C-W1, upper view (MUST-RCSP-CON. 0030), reworked conodont (explanations in the text). 


\subsection{Other fauna}

\subsubsection{Ostracods}

The Frasnian-Famennian (F/F) Kellwasser events resulted in the extinction of nearly $75 \%$ of marine ostracod taxa, mostly neritic or pelagic forms, whereas the deep-water Thuringian MegaAssemblage (TMA) was relatively unaffected (e.g. Crasquin and Horne 2018). A large number of ostracod shells (complete ones as well as isolated ones) were preserved in the residues (light fraction) for conodont preparation. Thirteen of the studied 45 samples contain ostracod specimens as single valves and carapaces. Due to an early diagenetic silicification (see the "Sedimentology and facies" section and the following), ostracod carapaces are mainly complete and show excellently preserved carapace surface sculptures (Fig. 5, Nazik et al. 2021).

Ostracods mainly occur in slightly silicified carbonates, which are characterized by spicule-rich laminae (e.g. calcareous siltstones). Distinct layers (e.g. HS-C-W1, western section) contain very diversified assemblages such as palaeocopid, platycopid, and podocopid groups of ostracods in one single sample. The overall ostracod fauna is widespread and diverse. The fauna shows affinities to known species from Europe, Russia, and to the Hongguleleng Formation, western Junggar Basin in China (Song and Gong 2019; Nazik et al. 2021), but endemic species and new species occur as well (Nazik et al. 2021). Generally, the ostracod assemblages found in the Hushoot Shiveetiin gol section are ecologically equivalent to the Eifelian Mega-Assemblage (IIII) which represents an overall nearshore palaeoenvironment. Ostracods are valuable proxies for palaeoecological interpretations and palaeoenvironmental conditions supporting the sedimentology and facies interpretation herein. Lethiers and Casier (1996) suggested that Famennian ostracods in the aftermath of the F/F extinction established from oxygen oases in shallow waters without reefs or mud mounds. In comparison to our studied section, it seems likely that diverse ostracod assemblages expanded from shallow-water refugia what would support the hypothesis from these authors. Due to the large number of different species, a detailed description and a discussion of palaeogeographic affinities will be published separately (Nazik et al. 2021).

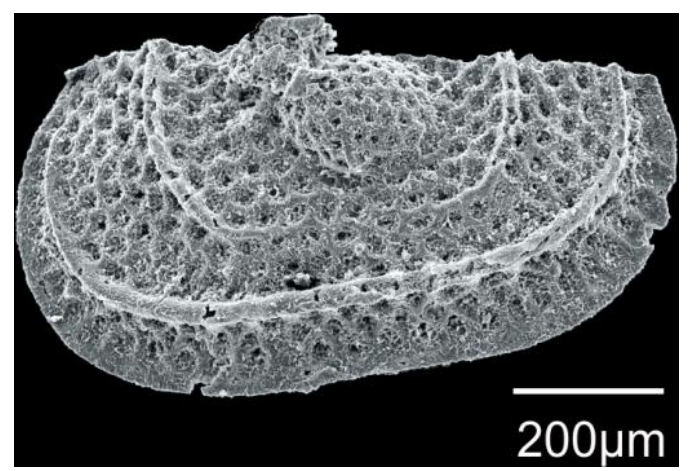

Fig. 5 Amphissites centrocostatus Blumenstengel 1969 (left valve, MUST-RCSP-OST. 0007), from the Palmatolepis rugosa trachytera Biozone of Unit VII, sample HS-C-W1). Note the well-preserved carapace surface sculpture. 


\subsubsection{Bryozoa}

The diversity of Devonian bryozoans displays a persistent rise from the Pragian to the early Givetian, before dropping significantly in the late Givetian as a result of the Taghanic Event. Bryozoans experienced a slight decline during the $\mathrm{F} / \mathrm{F}$ events, beginning their recovery during the middle Famennian (Ernst 2013 cum lit.). Based on results published by Ariunchimeg (2000), bryozoans found in the Samnuuruul Formation were correlative with the Simorinski horizon in Kazakhstan, the Late Famennian in the Rudny Altai, the Middle crepida (= Palmatolepis termini) Biozone in north-western China, and the Etroeungtian of Western Europe. Overall, the Samnuuruul Formation yielded numerous dendroid, encrusting and fenestrate colonies of 12 species and 11 genera (Ariunchimeg 2000).

\subsubsection{Brachiopods}

The Devonian was a time of high diversity of the Phylum Brachiopoda with the maximum of Phanerozoic diversity in the Emsian (Curry and Brunton 2007). The phylum was much affected by the Middle and Late Devonian extinction events such as the Choteč and Taghanic events and in particular the Kellwasser events at the Frasnian/Famennian boundary (Walliser 1996). Before the Famennian, all stocks of the Pentamerida, Orthoidea, Atrypida, the "stropheodontoid" Strophomenida, most delthyridoid spiriferids, and many other groups went extinct (Copper 1998; Brice et al. 2000). None of these occur in the Hushoot Shiveetiin gol section. In the Famennian, spiriferids along with rhynchonellids, productids, athyridids, and some orthids are the most common groups, and this applies to this section as well. The preservation of the material is not very good, but allows some preliminary statements:

The most abundant group throughout the section is the Spiriferida. The assemblages of several units (HS-F1, 3-7, 10, 13-17; HS-WS 30) contain a conspicuous, coarsely ribbed mucrospiriferine; the subfamily is restricted to the Middle and Late Devonian. The specimens, partly occurring in abundance (HS-F14), belong to a possibly undescribed genus characterized by extended, mucronate cardinal extremities, particularly strong sulcus-bounding costae on the ventral valve and deep corresponding furrows on the dorsal valve; the form resembles representatives of the Givetian-Frasnian genus Eleutherokomma. A possibly different species shows a medially depressed dorsal fold (in HS-F $15+16$ ). Cyrtospiriferids are a second group; the specimens from HS-WS 30 and HS-F 11 are preliminarily identified from external characters as Validospirifer vel Cyrtospirifer sp.

Numerous specimens of an unisulcate, costellate dalmanelloid (from levels HS-F1, 4, 5, 8, 10, 17) are identified as ?Aulacella sp., a second form with large, flabellate ventral muscle field (HSF6, 9-11) may belong to Rhipidomella. Identified on the genus level, both forms are stratigraphically insignificant. The strophomenoid genus Leptagonia has a Devonian-Early Carboniferous range; a still unidentifiable species occurs in HS-F $5+10$. A productellid with coarse spines on the ventral valve (Productella sp.?) occurs at a number of levels (HS-F7, 10, 13, $17,18)$, moreover a larger, shield-shaped productid (HS-F14 +18$)$ and small chonetoids (HS- 
F15 + 16). Smooth, lenticular forms, possibly athyridids, are present at several levels (HS-F6, 8, 10, 19, HS-WS-27). A few strongly plicate rhynchonellids (HS-F6, 7, 10, 12, 17) are present but too poorly preserved as to allow identification.

In summary, the brachiopod assemblages show a relatively low to moderate diversity pointing to somewhat restricted conditions of a shallow-water palaeoenvironment. Its overall character fits a Famennian age; the mucrospiriferine species is a late representative of its subfamily.

\subsubsection{Echinoderms}

Crinoids and blastoids from the Samnuuruul Formation are the most diverse and most abundant Palaeozoic echinoderm fauna known from Mongolia. The fauna consists of 12 genera of crinoids - 4 genera of camerates, 3 genera of flexibles, one disparid genus, and 4 genera of cladids. We also have identified two genera of blastoids, the first occurrence of the class in Mongolia. The echinoderms were collected from a relatively narrow stratigraphic interval in Unit IV in the western section in the Palmatolepis rhomboidea Biozone. Taxonomic details of the echinoderm fauna are published in Waters et al. (2021).

The fauna is comparable to the coeval echinoderm fauna from the Hongguleleng Formation in Xinjiang Uyghur Autonomous Province, China (Lane et al. 1997; Waters et al. 2003; Webster and Waters 2009); the fauna supports the hypothesis that the CAOB was a diversity hotspot for Famennian echinoderms and a precursor to the very successful echinoderm communities that dominated Mississippian shallow marine ecosystems globally (Waters et al. 2021).

\subsubsection{Trilobites}

Trilobites were relatively abundant and diverse in marine Devonian habitats. In particular, the Late Devonian epoch is important for the development of Phacopidae because the main groups of reduced-eyed or blind phacopids arose at that time (Crônier et al. 2013). During Late Devonian time, eustatic variations (transgressive-regressive pulses) had a major influence on the phacopid diversity and their evolution, leading to major bioevents such as the upper Kellwasser Event and the Hangenberg Crisis (Crônier et al. 2013). At the global scale, the Kellwasser events led to the extinction of almost all reefs and their associated trilobites (Lichidae), and a significant decrease in other trilobite taxa. The Kellwasser extinction especially affected phacopids adapted to life in deep benthic habitats and their biodiversity, and led to a turnover (Lerosey-Aubril and Feist 2012; Crônier et al. 2013). During the Famennian, trilobite diversity was punctuated by several bioevents (Crônier et al. 2013). In the late part of the Early Famennian, the significant post-Kellwasser event recovery marked a new step especially for phacopid trilobites with new blind phacopid genera from deep offshore habitats and eyed-phacopid genera from shallower habitats in the photic zone (Crônier et al. 2013; Feist 2019).

Excluding the Americas, Famennian phacopids are characterized by a worldwide distribution (Chlupáč 1975; Crônier and François 2014; Feist 2019). However, if the majority of genera is apparently limited to a single cratonic margin, the other few genera are cosmopolitan (Crônier 
and François 2014). New discoveries in unexploited areas such as the newly studied western Mongolia once again reveal the endemic nature of many genera. The studied material (Crônier et al. 2021) comes from one section, i.e. Hushoot Shiveetiin gol section, in three levels (levels HScono 1, 3, and 5 and 13) rich in diverse conodonts (Suttner et al. 2020) and macrofossils including brachiopods, solitary rugose corals, and branching tabulate corals. According to two endemic and few cosmopolitan conodont taxa found in this section, our trilobite samples range from the Palmatolepis crepida to the Palmatolepis rhomboidea biozones in the Early Famennian. The studied material is most often incomplete, difficult to prepare, and often preserved as an internal mold. Due to insufficient preservation of the cephalon and the pygidia, additional material is required. However, the only relatively well-preserved phacopid trilobite is assigned to a new genus (Crônier et al. 2021), thus becoming an endemic taxon from western Mongolia on account of the cephalic shape and doublure.

\subsection{Sedimentology and facies}

The Hushoot Shiveetiin gol section is divided into an eastern part and a western part (Fig. 1). Both sections can be correlated based on a pyroclastic marker horizon (HS-S-11, see Figs. 6 and 7) which occurs in the uppermost part of the eastern section and marks the beginning of the western section at the base. The distance between both sections is approximately $350 \mathrm{~m}$. Correlation is also proven by conodont data (see conodont zonation in each lithological log-left column). In the following description of different units, we summarize both sections. The Hushoot Shiveetiin gol section has a thickness of $148.50 \mathrm{~m}$ and is characterized by shallow-shelf mixed siliciclastic/carbonate facies and frequently intercalated volcaniclastic rocks. Geochemical analysis of the volcaniclastic units all suggest an island arc volcanic sediment source (Fig. 8), consistent with the tectonic interpretations of the region. Microfacies analysis allowed the discrimination of eight microfacies types (FT), which are described from shallowest to deepest palaeoenvironment. The Hushoot Shiveetiin gol section is of Famennian to (?)Early Mississippian age and ranges from the Palmatolepis minuta minuta Biozone to at least the Palmatolepis rugosa trachytera Biozone (biozonation follows Hartenfels 2011 and Spalletta et al. 2017). Unfortunately, the exposed, possible Lower Carboniferous rocks do not contain conodonts. The arkosic sandstones contain some plant remains which are less useful for very detailed stratigraphy, but most probably belong to the (?)Lower Mississippian.

\subsubsection{Lithological units of the Hushoot Shiveetiin gol section}

The Hushoot Shiveetiin gol section is subdivided into eight lithological units which are described from the base of the section ( $\mathrm{N} 45^{\circ} 16^{\prime} 19.4^{\prime \prime}$, E $\left.91^{\circ} 02^{\prime} 13.0^{\prime \prime}\right)$ to the top ( $\mathrm{N} 45^{\circ}$ $\left.16^{\prime} 19.8^{\prime \prime}, \mathrm{E} 91^{\circ} 02^{\prime} 53.2^{\prime \prime}\right)$. Unit $\mathrm{I}$ is mainly composed of siltstones in the lower part and siltstones and greenish shales in the upper part. Occasionally thin-bedded limestones and/or limestone lenses which are intercalated in siltstones occur. Some limestones yielded conodonts of Palmatolepis minuta minuta Biozone and Palmatolepis crepida Biozone (Fig. 6). In distinct layers, brachiopods, crinoids, and trilobites occur in descending order. A limited number of thin- 
bedded volcanic ashes occur in the lower and middle parts of this unit which has a thickness of $18 \mathrm{~m}$.

Unit II has a thickness of $19.5 \mathrm{~m}$ and is mainly composed of greenish shales. Intercalated are thin-bedded siltstones and limestones. Some of these limestones are fossiliferous yielding conodonts, brachiopods, crinoids, and bryozoans. Two layers of several-centimeter-thick ash beds occur in that unit. Youngest sediments of this unit belong to the Palmatolepis glabra prima Biozone. In contrast to the latter unit, Unit III exhibits change from greenish shales to more greyish shales. Intercalations of thin-bedded limestones and marly limestones occur, but most of them are barren. Within the base of this unit, the transition from the Palmatolepis glabra prima Biozone to Palmatolepis glabra pectinata Biozone could be determined. Unit III has a thickness of $19.9 \mathrm{~m}$.

Rocks of Unit IV occur in the eastern and the western sections. The rock sample HS-S-11 (pyroclastic ash) is the marker horizon, which occurs in both sections. In this unit, several lithological changes exist. The lower part is dominated by greenish shales, a number of volcanic ashes, and several fossiliferous limestones. Ash layers can reach a remarkable thickness of several decimeters to meters. Directly above the marker horizon, conodonts of the Palmatolepis rhomboidea Biozone were found in limestone nodules in both sections. Thus, the sections can be correlated by both lithology and biostratigraphy. Underlying sediments belong to the next older Palmatolepis glabra pectinata Biozone. In the upper part of this unit, more carbonate layers occur, intercalated in greenish shales, whereas ash layers become rare. Particularly, this part of the section shows cyclic sedimentation, a feature which is well known from other Famennian sections in shallow water as well as in hemipelagic facies (e.g. Hartenfels 2011; Hartenfels and Becker 2016). The rhythmite-bearing succession which might be associated with 405-kyr and 100-kyr eccentricity cycles (De Vleeschouwer, personal communication) may be linked with astronomical rhythms in Late Devonian sedimentary successions (e.g. De Vleeschouwer et al. 2013). In the uppermost part of this unit, conodonts of the next younger Palmatolepis gracilis gracilis Biozone were found. Unit IV has a thickness of $30.5 \mathrm{~m}$.

Unit $\mathrm{V}$ is composed of greenish shales with few intercalations of limestones and pyroclastic rocks. Generally, the thin carbonate layers are less fossiliferous; only some of them contain brachiopods. The thickness is $13 \mathrm{~m}$. The overlying Unit VI is characterized by the occurrence of greenish, nonfossiliferous shales, ash layers, and rare brownish shales and limestones. In the lower part, a remarkable thick-bedded shale with significant volcanic components of several meters' thickness occurs. In the middle part, a thick-bedded fossiliferous limestone occurs, which is mainly composed of bryozoans. The entire unit has a thickness of $31 \mathrm{~m}$. Due to the facies setting, no conodonts or macrofossils were found, and no biostratigraphic data for the interval of the Unit V and Unit VI are available. In terms of conodont biostratigraphy, we have a hiatus ranging from the Palmatolepis marginifera marginifera Biozone at least to the Scaphignathus velifer velifer Biozone because the conformably overlying unit yielded conodonts 
of the next younger Palmatolepis rugose trachytera Biozone. As there is no visible break in sedimentation we assume that this succession represents a continuous sedimentary record.

Unit VII shows a rather variable rock record in comparison to the previous units as this unit is composed of brownish and greenish shales, siltstones, sandstones, volcaniclastic sediments as well as fossiliferous limestones in the upper part where conodonts were found (Fig. 7). A precise biostratigraphic datum (Palmatolepis rugosa trachytera Biozone) comes from the youngest limestones found in the Hushoot Shiveetiin gol section. This unit has a thickness of $15.4 \mathrm{~m}$.

The overlying Unit VIII with an overall thickness of $11.1 \mathrm{~m}$ begins with the first thick-bedded sandstones, brownish shales, and thin-bedded sandstones, which are covered by thick-bedded sandstones showing sedimentary structures such as parallel bedding and cross bedding. The top of the Samnuuruul Formation at Hushoot Shiveetiin gol is composed of thick-bedded coarsegrained sandstones and conglomerates (Fig. 7) with macroscopic plant debris (Fig. 9). Similar successions are known from other sections in the vicinity (Kido et al. 2013) and may represent sediments of the Lower Carboniferous.

\subsubsection{Facies}

Samples for facies analysis were taken wherever distinctive facies differences were observed in the field. The overall facies setting ranges from shallow intertidal to open marine (mid- to outer ramp setting). In some diagnostic layers, a further subdivision into sub-environments, such as lagoonal setting, is possible. Lithological/facies differences at Hushoot Shiveetiin gol likely record a series of sea-level changes in the overall shallow-water sequence. A very common feature of the section is early diagenetic silicification, which is linked to the occurrence of sponge spicules providing the source of silica (e.g. Tucker and Wright 1990; Gimenez-Montsant et al. 1999). We recognized eight facies types (FT, including subfacies types) which are described and interpreted below from the shallowest to the deepest palaeoenvironmental setting.

\section{FT 1: arkosic sandstone}

This facies is limited to the youngest part of the section and is composed of medium to thickbedded arkosic sandstones. The clasts, which are mainly fine- to medium-grained (also coarse grained layers occur), are composed of quartz, feldspar (albite), varying amounts of other minerals, and rare lithic clasts, such as volcanic fragments. The sandstones contain less than $14 \%$ matrix. They exhibit alternations of cross-bedding and planar bedding. The internal structure of the latter bedding type is characterized by parallel, sometimes slightly wavy, sandy layers, several millimeters thick, sometimes showing gradation (fining-up; Fig. 10a, sample WS-S-4/2). Ripple marks of both current and wave origins can be found. In distinct layers, reworked wellrounded lithoclasts (mud-pebbles) occur. Lamination is also a common feature and associated with peloidal laminae, iron oxide grains, and small shell hash (Fig. 10b, sample WS-S-5). Bioturbation has not been found. The uppermost part of the section contains plant fossils (Fig. 9), 


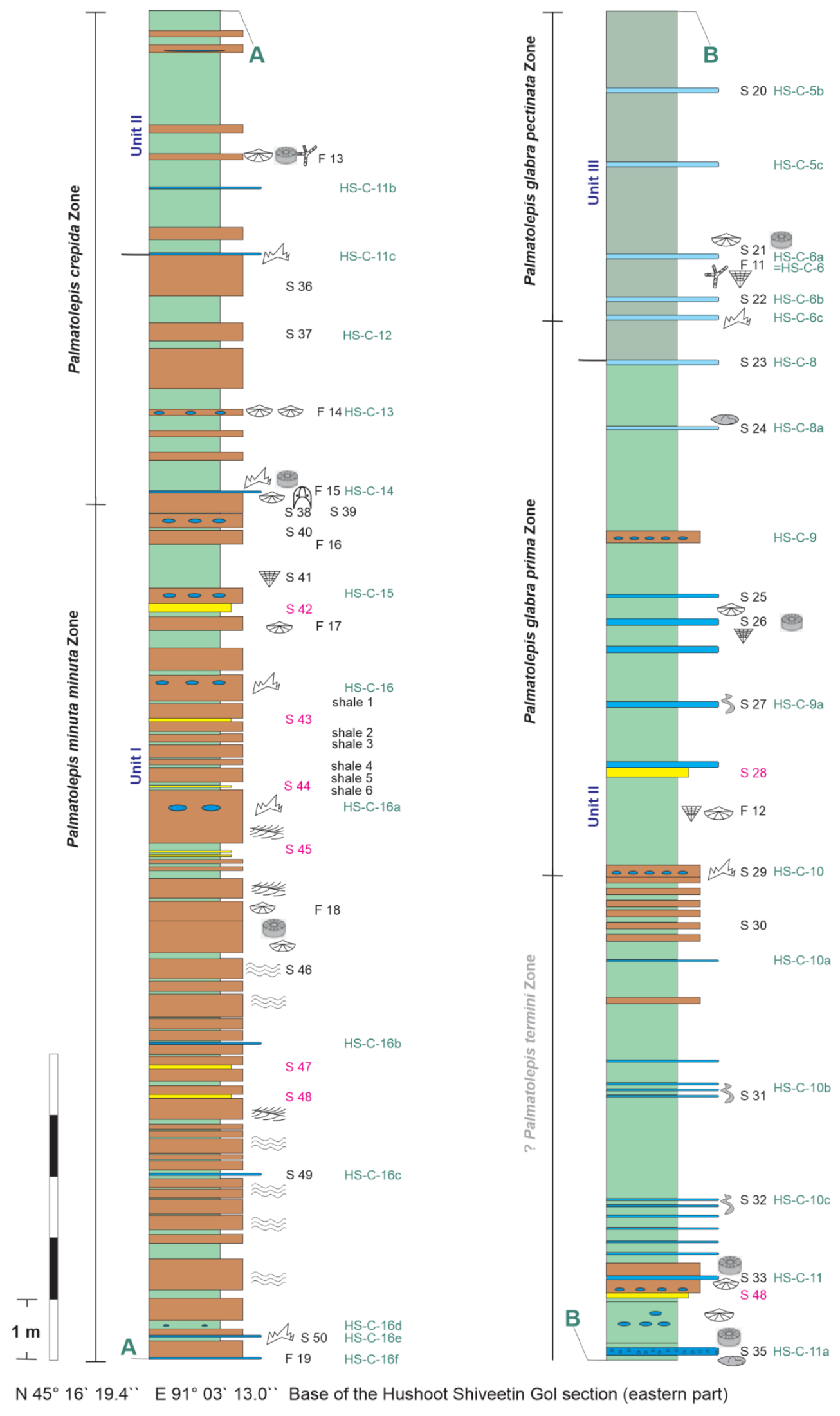

Fig.6. (continued) 


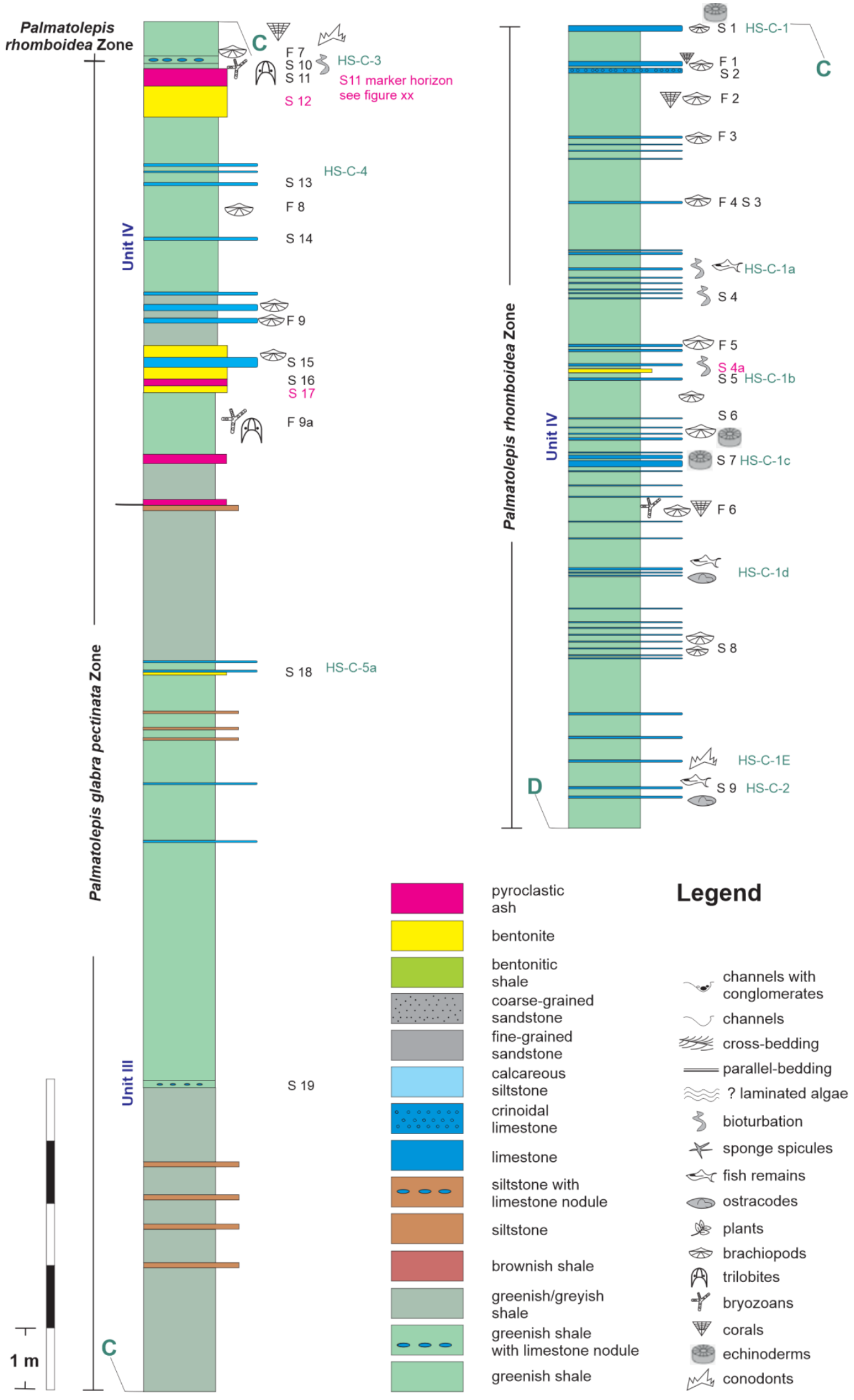


Fig. 6 Lithological log and conodont stratigraphy of the Hushoot Shiveetiin gol section (eastern part). The pyroclastic ash layer (rock sample S11) is a marker horizon which links the eastern and the western part (= rock sample WS-S-11 of the section) of the section. The left column shows the conodont biozones. Conodont biozones shown in black color are clearly indicated by either first appearance (FAD) or the presence of distinct taxa (including data from Suttner et al. 2020); insufficient data or no conodont data are marked with a "?" and are shown in gray color (further explanation in the text). The lithological log is subdivided into sedimentological units (Unit I to Unit IV). Abbreviations: for example "S 19"-sedimentology/facies sample, sample numbers shown in pink were taken for geochemistry; "shale 1"- sample for geochemistry; "HS-C-1c" — conodont sample (the samples which were taken in an earlier field campaign in 2014 - see Suttner et al. (2020) are also included in this log; samples from the western part were taken in 2018; "F 9"- -sample taken for macrofauna. The legend shown in these figures is also valid for the lithological log of the western section-see Fig. 7)

which point to an Early Carboniferous age. These rocks are also recorded in other sections in western Mongolia (Kido et al. 2013).

Interpretation: The overall facies points to a shallow-marine, intertidal to subtidal facies setting which is supported by channel lag deposits, and current and wave ripples. The horizontal bedding in fine-grained sandstone reflects deposition under hydrodynamic conditions of the upper flow regime (upper plane bed). The sandstones are perhaps deposited as a series of coastal barrier bars in a shallow-subtidal palaeoenvironment. Well-rounded lithoclasts are interpreted as reworked channel lag deposits from shallower parts as it has been described for instance from a land-sea transitional setting by Wehrmann et al. (2005) from the Devonian of the Rhenish Massif (Germany).

\section{FT 2: conglomeratic sandstones}

This conglomeratic sandstone facies contains approximately $5 \%$ of clasts having a ratio of sand to mud of 9:1. This facies occurs directly below facies type 1 (FT1). Because the lateral extension of the conglomerates is rather limited in the field, we interpret them to be the base of channel structures. The conglomeratic sandstone is matrix supported (Fig. 10c, sample WS-S-2). The size of the channels can reach up to $3 \mathrm{~m}$ in width. The polymict conglomerate represents sedimentary as well as volcanic rocks such as sandstones, carbonates, siltstones, and volcaniclastic rocks. The size of clasts ranges from mainly medium-sized, to occasionally coarsesized clasts but also gravel-sized clasts occur.

Interpretation: The coarsening upward sandstones at the base, conglomeratic sandstones and conglomerates at the top with large plant fossils point to palaeoenvironmental fluctuations between fluvial and shallow-subtidal. Conglomerates were deposited in channels. Due to the size of the conglomerate clasts as well as sedimentological characteristics, the facies requires a highenergy depositional environment with certain morphology/rapid uplift of the hinterland and/or sea-level changes of appropriate magnitude.

\section{FT 3: siltstones}

Siltstones mainly represent the lowermost part of the section (Unit I, Palmatolepis minuta minuta Biozone). Low-angle silt can be seen in some laminations, often associated with small scaled cross-bedding. The thickness of single layers varies from several millimeters to some 
centimeters. Some layers are unevenly laminated (particularly in the lowermost part of the section) and may represent "algal" mats which is hard to say due to silicification of the rocks. Some other layers exhibit limestone nodules which yielded rare conodonts, brachiopods, and crinoids.

\section{FT 3a: calcareous siltstones}

Calcareous siltstones mainly occur in Unit III. This facies is characterized by parallel bedding with single-layer thicknesses ranging from 0.1 to $0.5 \mathrm{~cm}$. Lamination is mainly composed of microspar laminae and peloidal laminae. Other layers do not exhibit bedding plane structures (Fig. 10d, sample HS-S-24/2). The latter feature is due to slight silicification. Some parallel beddings are enriched with pyrite and iron oxide grains, and also fecal pellets occur. Generally, the fossil content is low, apart from some isolated echinoderm remains and ostracods. Some layers exhibit small-scale current ripples and/or crossbedding structures similar to the abovedescribed facies.

Interpretation: Due to the observed sedimentological features (different ripple marks, parallel bedding), both facies settings represent a shallow-subtidal environment.

\section{FT 4: greenish, greyish, and brownish shales}

Greenish and grayish shales are the dominant rock type of Units IV to VI in the western section (Fig. 7). No sedimentary structures are visible. The small-sized grain-supported components of shales, the mixture with pyroclastic material, and the very limited number of fossils point to a palaeoenvironmental setting often with reworked sediments. Similar sedimentological characteristics are observed in the brownish shales which occur in Unit VII.

FT 4a: pyroclastic ash and volcanic ash

Pyroclastic deposits are considered as a sub-facies. These rocks occur in the entire section and are mainly intercalated in greenish-grayish shales described above. The volcaniclastic sediments are formed by accumulation of material generated by explosive fragmentation of magma and/or previously solid rock, during the course of volcanic eruptions. The components are covered by meteoric cement and exhibit normal as well as inverse gradation (Fig. 10e, sample WS-S-25/2). The latter one is an effect of gravitational differentiation of vesicular dacitic glass in the water column. Additional to the pyroclastic ash, a large number of bentonites also occur in the greenish-greyish shales (see Fig. 7) as well as in the brownish shales.

Interpretation: The pyroclastic layers (e.g. the marker horizon) and ash layers are mainly deposited within the greenish-grayish shales which represent a shallow-subtidal palaeoenvironment. 

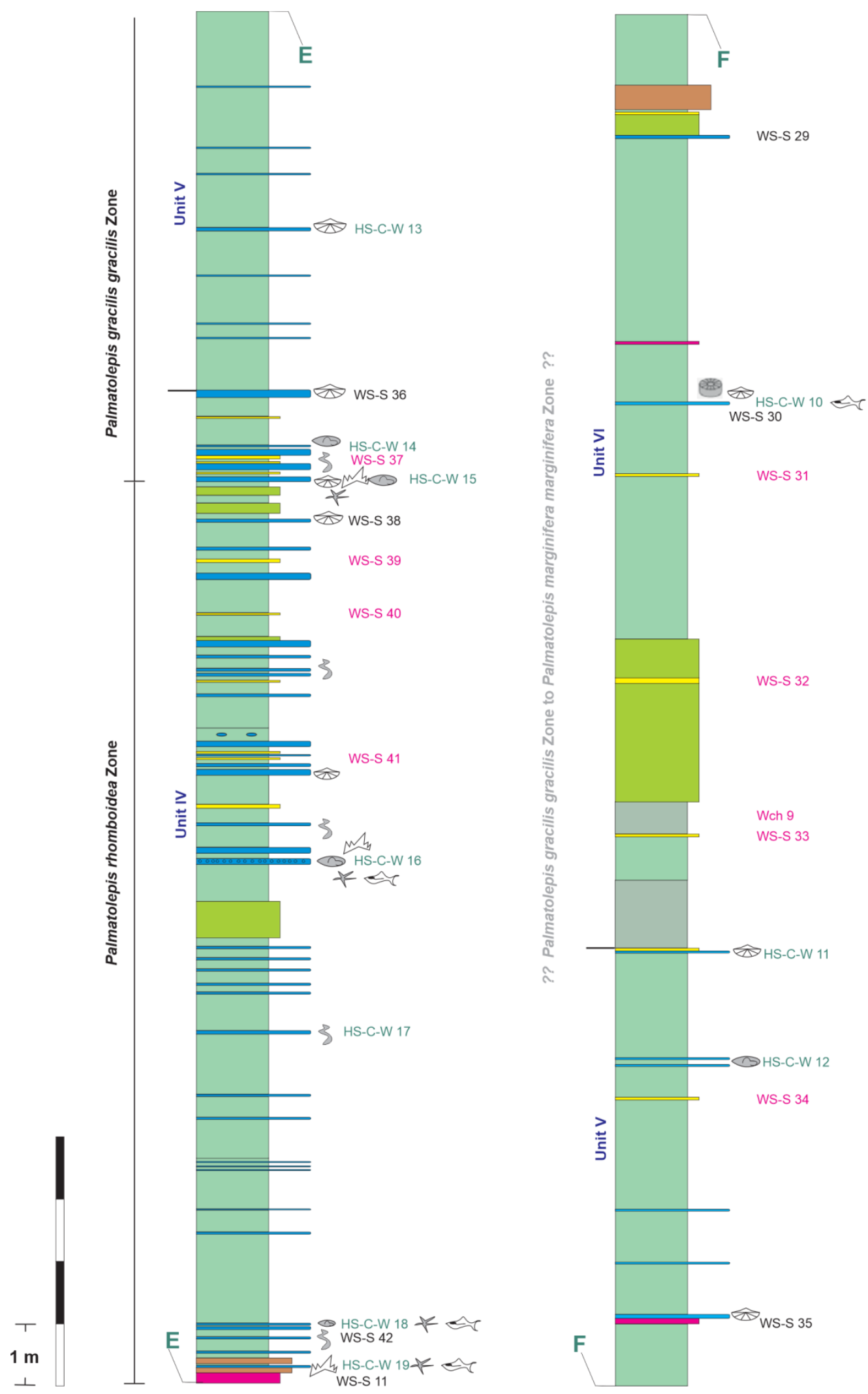

N $45^{\circ} 16^{\circ} 22.3^{\prime \prime}$ E $91^{\circ} 02^{\circ} 56.2^{\prime \prime}$ Base of the Hushoot Shiveetin Gol section (western part); $\mathrm{S} 11$ is the marker horizon of both sections

Fig.7. (continued) 


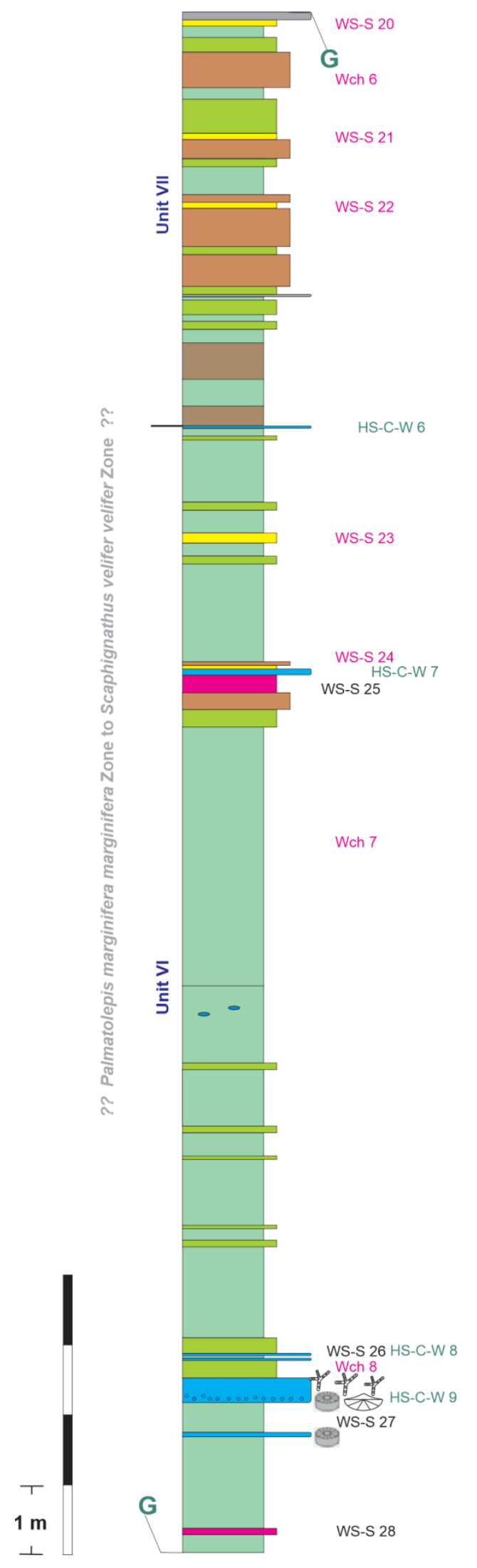

N 45 $16^{\prime} 19.8^{\prime \prime}$ E 9102 $53.2^{\prime \prime}$ Top of the Hushoot Shiveetin Gol section (western part)

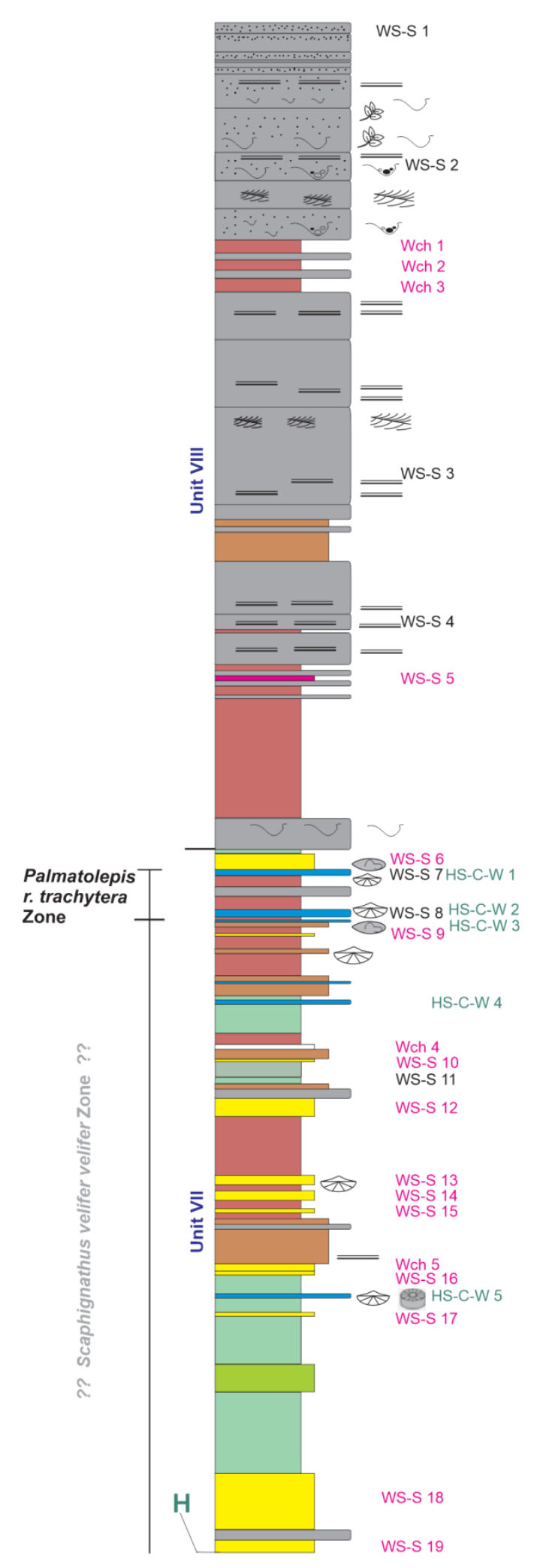


Fig. 7 Lithological $\log$ and conodont stratigraphy of the Hushoot Shiveetiin gol section (western part). The pyroclastic ash layer (rock sample WS-S-11) is a marker horizon which links the western and the eastern parts (= rock sample $\mathrm{S}$ 11) of the section. The left column shows the conodont zonation. Conodont biozones shown in black color are clearly indicated by either first appearance (FAD) or the presence of distinct taxa (including data from Suttner et al. 2020); insufficient data or no conodont data are marked with an "?" and are shown in gray color (further explanation in the text). The lithological log is subdivided into sedimentological units (Unit IV to Unit VIII). Abbreviations: for example "WS-S 42"—-sedimentology/facies sample, sample numbers shown in pink were taken for geochemistry; "Wch 9" —-sample for geochemistry; "HS-C-W17"—-sample for conodonts)

The volcaniclastic sediments in the meteoric phreatic zone were subject to active water circulation and represent a shallow-water, lagoonal facies setting. The mainly dacitic composition with rare quartz components (Fig. 10f, sample WS-S-35) of the pyroclastic ash point to subduction related volcanism. A semi-restricted lagoon setting is supported by the evaporate minerals found in the volcanic ash layers. Evaporite minerals include gypsum, barite, and celestine. In distinct layers within greenish shales, even shallower facies conditions may have occurred where assemblages of ostracods were found representing semi-restricted lagoonal facies settings (e.g. in Unit IV, eastern section, Nazik et al. 2021). In the brownish shales of Unit VII, diversified ostracod assemblages suggest a nearshore setting which supports the palaeoenvironmental interpretation based on facies and sedimentology. All in all, facies 1 to 4 are characterized by lateral facies changes with different hydrodynamic conditions and/or minor palaeobathymetrical differences and belong to a shallow-subtidal setting.

\section{FT 5: bioclastic wackestone with stromatactis}

Fenestral fabrics as shown in Fig. 11a (sample HS-S-5) preferably occur in mudstones, packstones, and bindstones (Flügel 2004), but they are also visible in wackestones and interpretations of the genesis of those open-space structures are quite abundant (e.g. Bourque and Boulvain 1993). From our point of view, dissolution of calcareous skeletons such as the large brachiopod shells are of early diagenetic origin which is in agreement with published data by Hladil (2005), Olchowy (2011), and Vachard et al. (2017). The fabric is characterized by a large amount of detrital sediment. This facies type occurs in Unit IV (eastern part, Palmatolepis rhomboidea Biozone, samples HS-S-4, HS-S-5) in the eastern and in the equivalent part of the western section.

Interpretation: Fenestral fabrics (dissolved skeletal elements) represent an open-marine palaeoenvironment above fair-weather wave base (mid-ramp setting). This interpretation is also supported by the assemblage of ostracods, which were found in these levels (samples HS-S-4, HS-S-5). The fauna is characterized by heavy shelled and frequently broken carapaces of adult podocopids and platycopids (Nazik et al. 2021) and point to fully marine conditions.

\section{FT 6: lime mudstone/wackestone}

These micritic sediments are characterized by disintegrated skeletal material and fine erosional detritus. Bioclasts are composed of abundant sponge spicules, rare crinoid ossicles, bryozoans 
(cryptostome), small trilobite remnants, and ostracods (Fig. 11b, sample HS-S-10/2). Sediments are strongly burrowed. This facies occurs in distinct layers in Units III and IV.

Interpretation: Due to the size (very small) and composition of bioclasts as well as strong bioturbation, a shallow marine (mid-ramp) setting is suggested. Although sponge spicules are more common in deeper-water palaeoenvironments, they also occur in shallow-water settings (Gammon and James 2000).

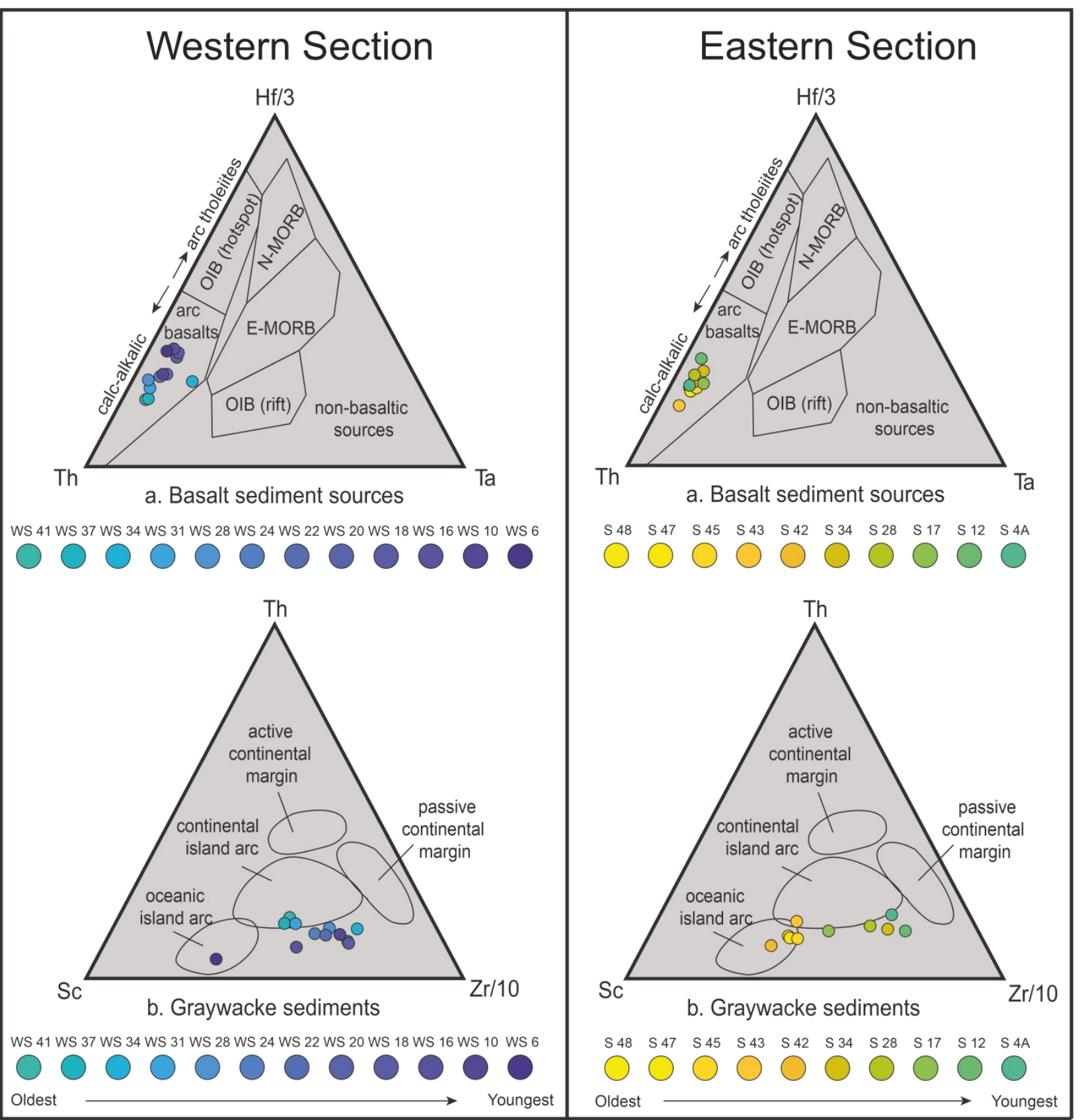

Fig. 8 Volcaniclastic sediment discrimination diagrams for the eastern and western sections. Modelled after Wood (1980) and Bhatia and Crook (1986). 


\section{FT 7: wackestone/floatstones}

The matrix-supported carbonate rocks yield mainly echinoderms, bryozoans, brachiopods, and corals (Fig. 11c, sample WS-S-30/3); some fossils are well-preserved, such as brachiopods and rare bivalves. The matrix is composed of micrite (lime mudstone). Mono-specific faunas composed of bryozoans or bryozoans and tabulate corals (Fig. 11d, sample WS-S-36/4) occur in this facies. Burrowing is common and similar to that described for FT 8.

Interpretation: These carbonates represent sediments of a low-energy palaeoenvironment below the fair-weather wave base (outer and mid-ramp setting). These sediments occur as distinct layers in Unit IV (Palmatolepis glabra pectinata to Palmatolepis rhomboidea biozones) and may represent sea-level rises in combination with reduced siliciclastic/volcaniclastic input.

\section{FT 8: bioclastic wackestone}

These carbonates exhibit a diverse fauna, such as corals, brachiopods, trilobites, and crinoid ossicles, and are partly strongly burrowed (Fig. 11e, HS-S-4/2). The matrix is mainly composed of micro-bioclastic pelmicrite, sometimes pelsparite occurs. As a result of transport, occasionally, the limestones show bedding and gradation (Fig. 11f, sample HS-S-1) which reflects changes in the hydrodynamic regime. These carbonates occur in the uppermost portion of the eastern section. They can be correlated with the western part (Unit IV) where they are intercalated in greenish shales. As shown in representative samples WS-S-36/4 and HS-S-1 (Figs. 11d, f), compaction formed under burial conditions is generally weak. As a result of this solution, seams occur either in irregular thin anastomosing sutured seams in lime mudstone and/or occur in sutured seams around bioclasts.

Interpretation: These rocks are known from more openmarine palaeoenvironments as well as from shallow open shelf lagoons (Flügel 2004). The latter facies setting also occurs in our section which is supported by the ostracod assemblage in some samples (HS-C-1a, HS-C-1b, HS-C-1d) where a palaeocopid ostracod fauna was found indicating restricted or semi-restricted nearshore palaeoenvironments (Nazik et al. 2021).

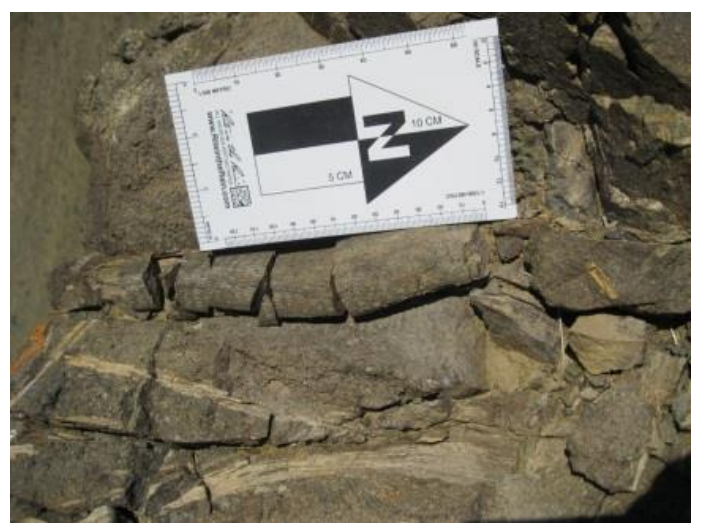

Fig. 9 Coarsening upward sandstones at the top of the Samnuuruul Formation with plant debris (large (?)lycopsid chunk) in Unit VIII of the Hushoot Shiveetiin gol section. 

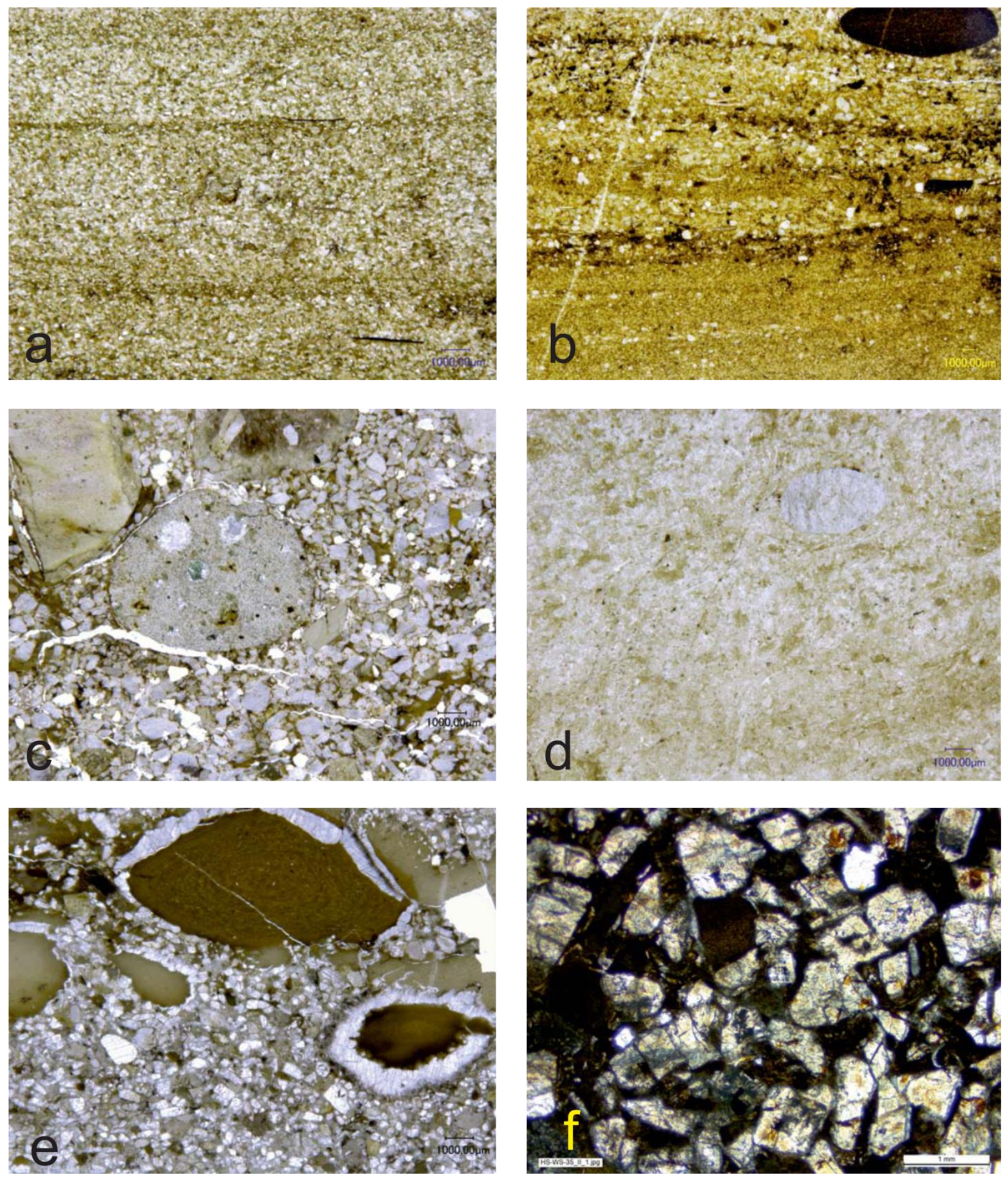

Fig. 10 Thin sections illustrating the facies of sampled rocks. a Parallel-bedded, several millimeters-thick layers (fining up) of arkosic sandstone (sample WS-S-4/2); b arkosic sandstone with lithoclasts reworked channel lag deposit, sample (WS-S-5); c matrix-supported polymict conglomeratic sandstone (sample WS-S-2); d slightly silicified calcareous siltstone with rare bioclasts (ostracods, sample HS-S-24/2); e larger pyroclastic components are covered preferably isopachous fringe of cement (sample WS-S-25/2). Aragonite (light cement) and Mg-calcite cement (dark cement) have different thicknesses; f pyroclastic ash which is mainly composed of plagioclase with rare quartz components (sample WS-S-35). 

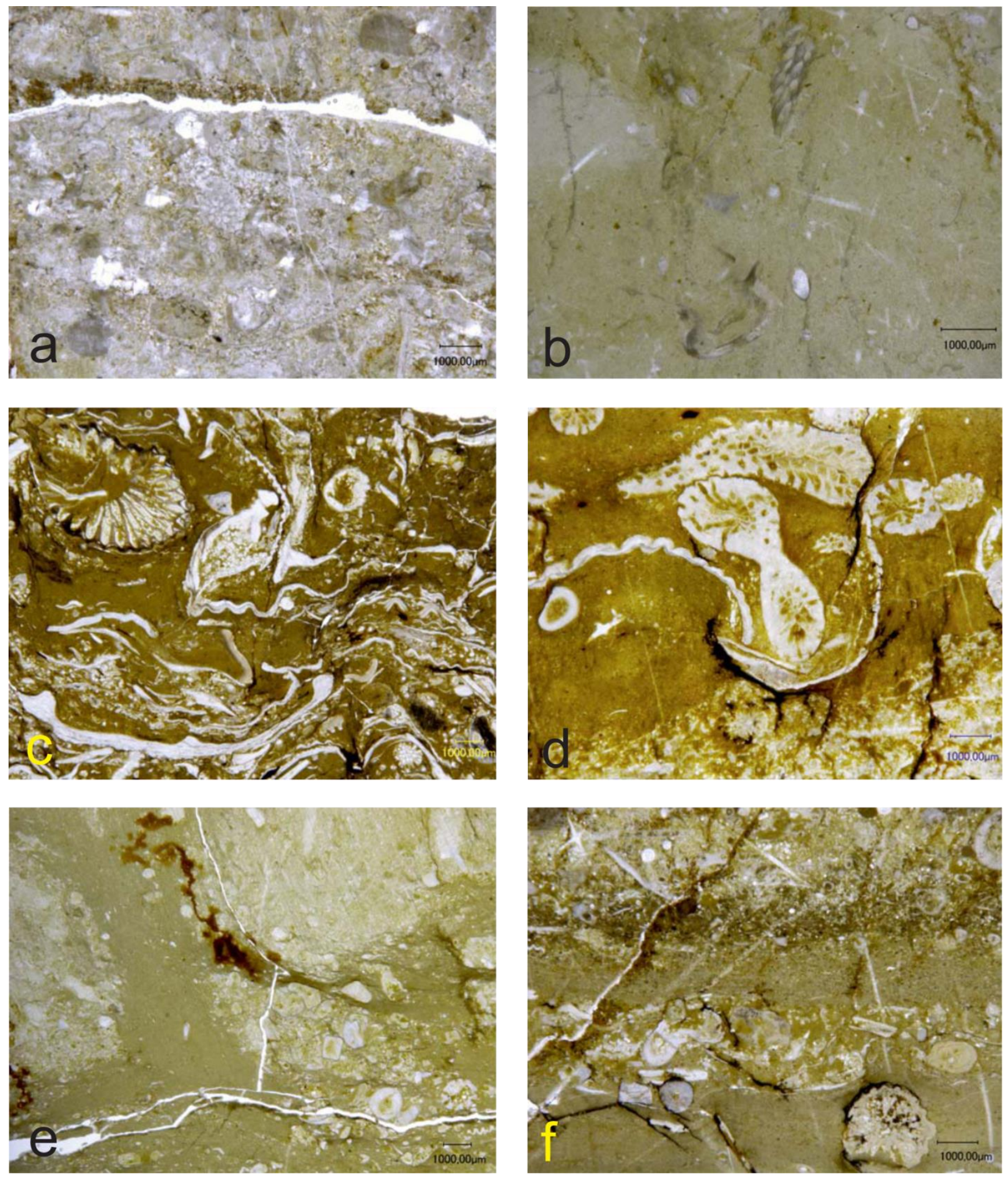

Fig. 11 Thin sections illustrating the microfacies of sampled limestones. a Stromatactis in bioclastic wackestone with dissolved brachiopod shell and reworked sediments above (sample HS-S-5). b Strongly bioturbated mudstone/wackestone with sponge spicules, trilobites, ostracods, and cryptostome bryozoans (sample HS-S-10/2). c Wackestone/floatstone with diverse fauna (sample WS-S-30/3). d Wackestone/floatstone with tabulate corals and bryozoans covers a fine-grained bioclastic wackestone with small shell hash and sponge spicules (sample WS-S36/4). e Strongly burrowed bioclastic wackestone with crionoid ossicles; sample HS-S-4/2). f Laminated limestone 
exhibits graded bedding which points to transport by wave or storm wave activity; large number of sponge spicules refer to early diagenesis (sample HS-S-1).

\section{Discussion}

The Samnuuruul Formation of the Hushoot Shiveetiin gol section in western Mongolia was investigated in detail during two field campaigns. The section ranges biostratigraphically from the Palmatolepis minuta minuta Biozone to at least the Palmatolepis rugosa trachytera Biozone. From the biostratigraphic point of view, based on conodonts, it is obvious that hiatuses of several conodont biozones within units V, VI, and the basal part of Unit VII are a result of facies related predominantly to shallow-water palaeoenvironments. As a result of that, the lack of some important zonal index taxa (e.g. Palmatolepis species) hampers precise conodont biostratigraphy of those parts of the section. The application of the revised Late Devonian conodont standard biozonation (Spalletta et al. 2017) in shallow-water realms is an ecologically driven problem and well known from other studies (e.g. Bahrami et al. 2018; Königshof et al. 2021) as most species preferably occur in more deeper-water settings. Furthermore, as already discussed in Suttner et al. (2020), ecological and geomorphological barriers might be another limiting factor that significantly influenced the distribution and radiation of conodont taxa of the island arc complex of the CAOB.

The exposed Upper Devonian to Lower Carboniferous sediments represent an overall shallowwater facies setting, which is mainly composed of siliciclastic rocks. The environmental setting is characterized by coeval volcanism, resulting in the deposition of pyroclastic sediments. The pyroclastic ashes showing mainly dacitic composition point to subduction related volcanism within an intra-oceanic arc. An island arc volcanic sediment source is also confirmed by the geochemical analysis (Fig. 8).

In comparison to other sections in the Baruunhuurai Terrane (Kido et al. 2013), the Hushoot Shiveetiin gol section exhibits significant differences, such as the large amount of volcaniclastic sediments, but the sandstones and conglomerates in the uppermost part of the section are similar to other sections within the terrane. It seems likely that these sediments can be correlated with rocks of Unit IV published by Kido et al. (2013). The coarsening upward sandstones and conglomerates with interbedded siltstones and shales often containing plant fossils, such as large chunks of lycopsid stems (Kido et al. 2013, Fig. 15), are similar to the Hushoot Shiveetiin gol section. These sediments grade upwards into weathered shale and coal which most likely cross the Devonian/Carboniferous boundary (Kido et al. 2013).

According to Kaufmann's (2006) geochronology, approximately 4.7 myr separate the Palmatolepis rugosa trachytera Biozone from the D/C boundary. Becker et al. (2012) suggested a slightly shorter duration for the same interval. The sedimentary thickness from the last limestone (Palmatolepis rugosa trachytera Biozone) until the first thick-bedded sandstone in the Hushoot Shiveetiin gol section is less than $1 \mathrm{~m}$. Whether this sandstone is an equivalent to the Hangenberg sandstone (due to remarkable sea-level fall) or rather a local event due to tectonic 
processes remains unknown at this time. The Devonian/Carboniferous boundary is believed to occur somewhere within the Unit VIII sandstone/shale succession. Upwards, the sediments grade into thick-bedded arkosic sandstones and conglomerates with plant debris, which are assigned to the Early Carboniferous. There is no evidence for black shales and/or coal units as described in the section by Kido et al. (2013), so a possible hiatus in UnitVIII could be possible even if largescale sedimentary discontinuities are not visible in the field. Another explanation is that the sediments described by Kido et al. (2013) represent a different depositional facies. Black shale and coal may not necessarily be preserved in high-energy marine to restricted coastal depositional environments. Thus, our section may also represent a coeval, slightly different facies setting where coal deposits did not occur.

The uppermost part of the Unit VII is represented by an increasing number of fossiliferous limestones, which are linked with transgressive pulses and more oligotrophic conditions. The latter assumption is supported by the occurrence of large numbers of platycopid ostracods. According to Lethiers and Whatley $(1994,1995)$ and Whatley et al. (2003), the "Platycopid Signal" hypothesis provides a valuable tool for studying of Oceanic Anoxic Events (OAE's) as this model indicates that the percentages of platycopid species in ostracod assemblages correlate with the ranges of dissolved oxygen levels. In a more recent paper by Horne et al. (2011), an alternative interpretation was given. Ostracod assemblages dominated by platycopids point to oligotrophic conditions. In comparison to living platycopids, they appear to be adapted to filterfeeding on nano- and picoplankton which preferably occurs in oligotrophic conditions (Horne et al. 2011). Furthermore, an increasing number of platycopids is obviously linked with transgression, whereas a decrease point to regression (Song and Gong 2019). The latter interpretation corresponds to facies analysis in this study. Transgressive pulses in the upper part of the Samnuuruul Formation are linked with the occurrence of several fossiliferous limestone layers in Unit V and a thick layer in Unit VI and two layers in the Palmatolepis rugosa trachytera Biozone (Fig. 7). On the other hand, the recognized transgressive pulses do not mirror the known T-R cycles in the Famennian (e.g. Johnson et al. 1985; Sandberg et al. 2002). It might be that the interglacial episode described by Sandberg et al. (2002, Event 15) previously assigned roughly to the trachytera Biozone (Sandberg et al. 1989) is represented by the last carbonate layers in our section, but it seems more likely that sea-level changes are a result of regional circumstances (e.g. synsedimentary tectonics due to volcanic activity) rather than representing eustatic sea-level changes.

In a number of recent publications, volcanic eruptions have been considered as a central key to ecosystem perturbations on a variety of spatial and time scales in the Earth's history. Volcanism has been accepted as the main trigger of global biodiversity crises (Wignall 2016; Bond and Wignall 2014; In Bond and Grasby 2017; Ernst and Youbi 2017; Racki et al. 2018a, b; Clapham and Renne 2019; Racki 2019, among others). At the F/F and D/C boundaries in the Late Devonian, large-scale volcanic activity is known from some places (see papers published by Liu et al. 2012; Marynowski et al. 2012; Percival et al. 2018) or indirectly suggested by $\mathrm{Hg}$ 
anomalies (Racki et al. 2018a; Paschall et al. 2019). The environmental setting of the Hushoot Shiveetiin gol section is characterized by a very large number of coeval ash deposits, some of which have a thickness of several meters.

\section{Conclusion}

- Based on conodont stratigraphy, the Hushoot Shiveetiin gol section ranges from the Palmatolepis minuta minuta Biozone to at least the Palmatolepis rugosa trachytera Biozone. Stratigraphical hiatuses of several conodont biozones occur due to depositional setting rather than folding and/or thrusting.

- The entire section most probably ranges from the Famennian to the Lower Mississippian even if we are not able to pinpoint the D/C boundary. Based on lithological correlation with other sections in the vicinity of the Hushoot Shiveetiin gol section, it seems likely that the arkosic sandstones represent the uppermost Famennian sediments. The D/C boundary most probably occurs somewhere in Unit VIII.

- Sedimentary structures such as ripple cross-stratification, parallel bedding, mud-pebble lags, and channel-fill structures are common throughout the section, whereas bioturbation is restricted mostly to the fossiliferous intervals, both indicating a variable depositional facies setting from shallow-intertidal to open marine. Palaeoenvironmental interpretations provided by facies analysis are also in agreement with evaporite minerals found in the volcanic ash layers.

- Macrofossils were found in this section in distinct horizons, such as trilobites, bryozoans, echinoderms, and brachiopods. Whereas some groups are relatively abundant and diverse such as trilobites and bryozoans, and in particular echinoderms and ostracods, brachiopods show a low to moderate diversity which is most probably related to somewhat restricted conditions and/or triggered by the intensive volcanic activity during the Famennian in this area.

- The diverse ostracod Eifelian Mega-Assemblage I-III (Nazik et al. 2021) expanding from shallow-water refugia supports the idea of the CAOB as a biodiversity hotspot in the aftermath of the $\mathrm{F} / \mathrm{F}$ extinction as it was already shown from other fossil groups (Waters et al. 2003; Webster and Waters 2009; Ernst 2013).

\section{Acknowledgements}

We are grateful to Jana Anger (Senckenberg Institute, Frankfurt) for conodont and thin section preparation. Hanna Cieszynski (Cologne) took the REM photographs of conodont sample HS-CW1. We also thank the entireMongolian team for their tremendous support in preparing the expedition and during our stay in the field camp. We thank Gary Webster (USA) and an anonymous reviewer for their comments and suggestions. This paper is a contribution to IGCP Project 652 ("Reading geologic time in Palaeozoic sedimentary rocks: the need for an integrated stratigraphy [2017-2021]”). 


\section{Funding}

Open Access funding enabled and organized by Projekt DEAL. M. Ariuntogos received funding from the German Academic Exchange Service (DAAD, Research Grant - Doctoral Program in Germany, September 01, 2018-September 01, 2021; 57381412). P. Königshof has received funding from Deutsche Forschungsgemeinschaft (DFG KO-1622/19-1). Sarah Carmichael and Johnny Waters received support from National Geographic (CP-113R-17) and Appalachian State University. Allison Dombrowski and Olivia Paschall receiving funding from the Explorers Club Youth Activity Fund and Appalachian State University.

\section{Compliance with ethical standards}

Conflict of interest: The authors declare that they have no conflict of interest.

Open Access This article is licensed under a Creative Commons Attribution 4.0 International License, which permits use, sharing, adaptation, distribution and reproduction in any medium or format, as long as you give appropriate credit to the original author(s) and the source, provide a link to the Creative Commons licence, and indicate if changes were made. The images or other third party material in this article are included in the article's Creative Commons licence, unless indicated otherwise in a credit line to the material. If material is not included in the article's Creative Commons licence and your intended use is not permitted by statutory regulation or exceeds the permitted use, you will need to obtain permission directly from the copyright holder. To view a copy of this licence, visit http://creativecommons.org/licenses/by/4.0/.

\section{References}

Algeo, T.J., \& Scheckler, S.E. (1998). Terrestrial-marine teleconnections in the Devonian: links between the evolution of land plants, weathering processes, and marine anoxic events. Philosophical Transactions of The Royal Society, B Biological Sciences, 353(1365), 113-130. https://doi.org/10.1098/rstb.1998.0195.

Ariunchimeg, Ya. (2000). The first finds of Famennian bryozoans in Mongolia. Paleontologicheskii Zhurnal 1, 45-48. [In Russian].

Ariunchimeg, Ya., Bayasgalan, A., Waters, J.A., Kido, E., Suttner, T.J., Sersmaa, G., Undariya, J., \& Otgonbaatar, D. (2014). IGCP 596 IGCP580 Field Workshop Guidebook. 8-18th August, 2014, Ulaanbaatar, Mongolia. Paleontological Center, Mongolian Academy of Sciences, pp. 155.

Ashouri, A.R. (2006). Middle Devonian-Early Carboniferous conodont faunas from the Khoshyeilagh Formation, Alborz Mountains, north Iran. Journal of Sciences, 17, 53-65.

Badarch, G., Byamba, J., Mahbadar, Ts., Minjin, Ch., Orolmaa, D., Tumurtogoo, O., \& Khosbayar, Ts. (1998). Summary. In: Tumurtogoo, O., Byamba, J., Badarch, G., Minjin, Ch., Orolmaa, D., Khosbayar, Ts., Chuluun, D., Makhbadar, Ts., \& Bat-Ireedui, Ya. (1998). 
Geological map of Mongolia, scale 1:1,000,000: Mineral resources Authority of Mongolia. Geological Survey and Mongolian Academy of Sciences, Institute of Geology and Mineral Resources, Ulaanbaatar, 1-30 [In Mongolian].

Bahrami, A., Königshof, P., Boncheva, I., Yazdi, M., Ahmadi Nahre Khalaji, M., \& Zarei, E. (2018). Conodont biostratigraphy of the Kesheh and Dizlu sections, and the age range of the Bahram formation in Central Iran. Palaeobiodiversity and Palaeoenvironments, 98, 315-329. https://doi.org/10.1007/s12549-017-0307-y.

Bahrami, A., Königshof, P., Vaziri-Moghaddam, H., Shakeri, B., \& Boncheva, I. (2019). Conodont stratigraphy and conodont biofacies of the shallow-water Kuh-e-Bande-Abdol-Hossein section (SE Anarak, Central Iran). Palaeobiodiversity and Palaeoenvironments, 99, 477-494. https://doi.org/10.1007/s12549-019-00384-5.

Barskov, I.S., Vorontzova, T.N., Kononova, L.I., \& Kuzmin, A.V. (1991). Index conodonts of the Devonian and Lower Carboniferous. Moskowskiy gosudarstvenniy universitet, 183.

Becker, R.T., Gradstein, F.M., \& Hammer, O. (2012). The Devonian period. In F.M. Gradstein (Ed.), The Geologic Time Scale (Vol. 2, pp. 559-601). https://doi.org/10.1016/B978-0-444$\underline{59425-9.00022-6 .}$.

Becker, R.T., Königshof, P., \& Brett, C.E. (Eds). (2016). Devonian climate, sea level and evolutionary events: an introduction. Geological Society of London, Special Publication 432, 110. https://doi.org/10.1144/SP423.15.

Bhatia, M.R., \& Crook, K.A.W. (1986). Trace element characteristics of graywackes and tectonic setting discrimination of sedimentary basins. Contributions to Mineralogy and Petrology, 92(2), 181-193. https://doi.org/10.1007/BF00375292.

Blumenstengel, H. (1969). Oberdevonische Ostracoden aus der Bohrung Mandelholz 18/56 (Harz, Elbingeroder Komplex). Freiberger Forschungshefte C, 256, 7-36.

Bolshakova, L.N., Bondarenko, O.B., Minjin, Ch., Ulitina, L.M., \& Sharkova, T.T. (2003). Paleontology of Mongolia: corals and stromatoporoids. Nauka, Moskow, pp. 199-256, [In Russian].

Bond, D.P.G., \& Grasby, S.E. (2017). On the causes of mass extinctions. Palaeogeography Palaeoclimatology Palaeoecology, 478, 3-29. https://doi.org/10.1016/j.palaeo.2016.11.005.

Bond, D.P.G., \& Wignall, P.B. (2014). Large igneous provinces and mass extinctions: an update. In G. Keller, \& A.C. Kerr, (Eds.), Volcanism, Impacts, and mass extinctions: causes and effects. Geological Society of America, Special Paper, 505, 339-352, https://doi.org/10.1130/2014.2505(02). 
Bourque, P.A., \& Boulvain, F. (1993). A model for the origin and petrogenesis of the red stromatactis limestone of Paleozoic carbonate mounds. Journal of Sedimentary Petrology, 63(4), 607-619. https://doi.org/10.1306/D4267B8B-2B26-11D7-8648000102C1865D.

Brice, D., Carls, P., Cocks, L.R.M., Copper, P., Garcia-Alcalde, J.L., Godefroid, J., \& Racheboeuf, P.R. (2000). Brachiopoda. In P. Bultynck, (Ed.), Subcommission on Devonian stratigraphy - fossil groups important for boundary definition. Courier Forschungsinstitut Senckenberg, 220, 65-86.

Carmichael, S.K., Water, J.A., Königshof, P., Suttner, T.J., \& Kido, E. (2019). Paleogeography and paleoenvironments of the Late Devonian Kellwasser event: a review of its sedimentological and geochemical expression. Global and Planetary Change, 183, 1-25. https://doi.org/10.1016/j.gloplacha.2019.102984.

Carmichael, S.K., Waters, J.A., Suttner, T.J., Kido, E., \& DeReuil, A.A. (2014). A new model for the Kellwasser anoxia events (Late Devonian): shallow water anoxia in an open oceanic setting in the Central Asian Orogenic Belt. Palaeogeography, Palaeoclimatology, Palaeoecology, 399, 394-403. https://doi.org/10.1016/j.palaeo.2014.02.016.

Chlupáć, I. (1975). The distribution of phacopid trilobites in space and time. Fossils and Strata, 4, 399-408.

Choulet, F., Cluzel, D., Faure, M., Lin, W., Wang, B., Chen, Y., Wu, F.Y., \& Ji, W. (2012). New constraints on the pre-Permian continental crust growth of Central Asia (West Junggar, China) by $\mathrm{U}-\mathrm{Pb}$ and $\mathrm{Hf}$ isotopic data from detrital zircon. Terra Nova, 24, 189-198. https://doi.org/10.1111/j.1365-3121.2011.01052.x.

Clapham, M.E., \& Renne, P.R. (2019). Flood basalts and mass extinctions. Annual Review of Earth and Planetary Sciences, 47, 275-303.

Copper, P. (1998). Evaluating the Frasnian-Famennian mass extinction: comparing brachiopod faunas. Acta Palaeontologica Polonica, 43, 137-154.

Crasquin, S., \& Horne, D.J. (2018). The Palaeopsychrosphere in the Devonian. Lethaia, 51, 547563. https://doi.org/10.1111/let.12277.

Crônier, C., \& François, A. (2014). Distribution patterns of Upper Devonian phacopid trilobites: paleobiogeographical and paleoenvironmental significance. Palaeogeography, Palaeoclimatology, Palaeoecology, 404, 12-23.

Crônier, C., Malti, F.Z., François, A., Benyoucef, M., \& Brice, D. (2013). First occurrence of a phacopid trilobite faunule from the Upper Devonian of Saoura Valley, Algeria and biodiversity fluctuations. Geological Magazine, 150, 1002-1021. 
Crônier, C., Ariuntogos, M., Königshof, P., Waters, J., \& Carmichael, S. (2021). Late Devonian (Famennian) phacopid trilobites from western Mongolia. Palaeobiodiversity and Palaeoenvironments, 101(3). https://doi.org/10.1007/s12549-020-00449-w.

Curry, G.B., \& Brunton, C.H.C. (2007). Stratigraphic distribution of brachiopods. In P.A. Selden, (Ed.), Treatise on invertebrate Paleontology, Part H Brachiopod, 6, supplement: 29012965. Boulder, Colorado and Lawrence, Kansas, Geological Society of America Inc. and University of Kansas.

De Vleeschouwer, D., Rakociński, M., Racki, G., Bond, D.P.G., Sobień, K., \& Claeys, P. (2013). The astronomical rhythm of late-Devonian climate change (Kowala section, Holy Cross Mountains, Poland). Earth and Planetary Science Letters, 365, 25-37. https://doi.org/10.1016/j.eps1.2013.01.016.

Dergunov, A.B. (Ed.) (2001). Tectonics, Magmatism, and Metallogeny of Mongolia. LondonNew York, Routledge, 288.

Donskaya, T.V., Gladkochub, D.P., \& Mazukabzov, A.M. (2013). Late Paleozoic-Mesozoic subduction-related magmatism at the southern margin of the Siberian continent and the 150 million-year history of the Mongol-Okhotsk Ocean. Journal of Asian Earth Sciences, 62, 79-97. https://doi.org/10.1016/j.jseaes.2012.07.023.

Epstein, A.G., Epstein, J.B., \& Harris, L.D. (1977). Conodont colour alteration - an index to organic metamorphism. Geological Survey of America, Professional Paper, 995, 1-27.

Ernst, A. (2013). Diversity dynamics and evolutionary patterns of Devonian Bryozoa. Paleobiodiversity and Paleoenvironments, 93(1), 45-63. https://doi.org/10.1007/s12549-012$\underline{0086-4}$.

Ernst, R.E., \& Youbi, N. (2017). How large igneous provinces affect global climate, sometimes cause mass extinctions, and represent natural markers in the geological record. Palaeogeography, Palaeoclimatology, Palaeoecology, 478, 30-52. https://doi.org/10.1016/j.palaeo.2017.03.014.

Feist, R. (2019). Post-Kellwasser event recovery and diversification of phacopid trilobites in the early Famennian (Late Devonian). Bulletin of Geosciences, 94, 1-22.

Flügel, E. (2004). Microfacies of carbonate rocks. Berlin: Springer. Folk, R.L. (1954). The distinction between grain size and mineral composition in sedimentary-rock nomenclature. The Journal of Geology, 62(4), 344-359. https://doi.org/10.1086/626171.

Gammon, P.R., \& James, N.P. (2000). Palaeogeographical influence on Late Eocene biosiliceous sponge-rich sedimentation, Southern Western Australia. Sedimentology, 48(3), 559-584. https://doi.org/10.1046/j.1365-3091.2001.00379.x. 
Gimenez-Montsant, J., Calvet, F., \& Tucker, M.E. (1999). Silica diagenesis in Eocene shallowwater platform carbonates, southern Pyrenees. The Journal of the International Association of Sedimentologists, Sedimentology, 46(6), 969-984. https://doi.org/10.1046/j.13653091.1999.00231.x.

Hartenfels, S. (2011). Die globalen Annulata-Events und die Dasberg-Krise (Famennium, Oberdevon) in Europa und Nord-Afrika - hochauflösende Conodonten-Stratigraphie, KarbonatMikrofazies, Paläoökologie und Paläodiversität. Münsterische Forschungen zur Geologie und Paläontologie, 105, 17-527.

Hartenfels, S., \& Becker, R.T. (2016). Famennian sedimentation, faunas, and event stratigraphy at Effenberg Quarry (Remscheid-Altena Anticline, Rhenish Massif). Münstersche Forschungen zur Geologie und Paläontologie, 108, 141-157.

Hladil, J. (2005). The formation of stromatactis-type fenestral structures during the sedimentation of experimental slurries-a possible clue to a 120-year-old puzzle about stromatactis. Bulletin of Geosciences, 80(3), 193-211.

Horne, D.J., Brandāo, S.N., \& Slipper, I.J. (2011). The Platycopid signal deciphered: responses of ostracod taxa to environmental change during the Cenomanian-Turonian boundary event (Late Cretaceous) in SE England. Elsevier, Palaeogeography, Palaeoclimatology, Palaeoecology, 308(3-4), 304-312. https://doi.org/10.1016/j.palaeo.2011.05.034.

Johnson, J.G., Klapper, G., \& Sandberg, C.A. (1985). Devonian eustatic fluctuations in Euramerica. Geological Society of America Bulletin, 96, 567-587.

Kaiser, S.I., Aretz, M., \& Becker, R.T. (2016). The global Hangenberg Crisis (DevonianCarboniferous transition): review of a first-order mass extinction. In R.T. Becker, P. Königshof, \& C.E. Brett, (Eds.), Devonian climate, sea level and evolutionary events. Geological Society, London, Special Publications, 423, 387-437.

Kaufmann, B. (2006). Calibrating the Devonian time scale: a synthesis of U-Pb ID-TIMS ages and conodont stratigraphy. Earth-Science Reviews, 76, 175-190. https://doi.org/10.1016/j.earscirev.2006.01.001.

Kido, E., Suttner, T.J., Waters, J.A., Ariunchimeg, Ya., Sersmaa, G., Atwood, J.W., \& Webster, G.D. (2013). Devonian deposits of the Baruunkhuurai Terrane, western Mongolia (IGCP 596 Field Workshop). Episodes, 36(4), 242-254. https://doi.org/10.18814/epiiugs/2013/v36i4/001.

Königshof, P., Bahrami, A., \& Kaiser, S.I. (2021). Devonian-Carboniferous boundary sections in Iran. In M. Aretz, \& C. Corradini, (Eds.), Devonian-Carboniferous boundary. Palaeobiodiversity and Palaeoenvironments, 101(2), 613-632. https://doi.org/10.1007/s12549-020-000438-z. 
Lane, N.G., Waters, J.A., \& Maples, C.G. (1997). Echinodermfaunas of the Hongguleleng Formation, Late Devonian (Famennian), Xinjian-Uygur Autonomous Region, China. Paleontological Society, Memoir, 47, 1-43.

Lazarev, S.S., \& Suurisuren, Sh. (1992). New productids (Brachiopoda) from Carboniferous of Mongolia. In: Grunt, T.A (Ed.), New Taxa of invertebrate fossils from Mongolia, Trudy joint Russian/Mongolian paleontological expedition vol. 41, 61-70 [In Russian].

Lerosey-Aubril, R., \& Feist, R. (2012). Quantitative approach of diversity and decline in late Palaeozoic trilobites. In J.A. Talent (Ed.), Earth and life: global biodiversity, extinction intervals and biogeographic perturbations through time (pp. 535-555). Springer Publishing.

Lethiers, F., \& Casier, J.G. (1996). Les Ostracodes survivants à l'événement F/F dans le limitotype de Coumiac (Montagne Noire, France). Annales de la Société géologique de Belgique, 117(1), 137-153.

Lethiers, F., \& Whatley, R. (1994). The use of Ostracoda to reconstruct the oxygen levels of Late Paleozoic oceans. Marine Micropaleontology, 24, 57-69. https://doi.org/10.1016/0377$\underline{8398(94) 90011-6 .}$.

Lethiers, F., \& Whatley, R. (1995). Oxygénation des eaux etostracodes filtreurs: Application au Devonien-Dinantien. Geobios, 28(2), 199-207. https://doi.org/10.1016/S0016-6995(95)80227-4.

Li, P., Sun, M., Rosenbaum, G., Jourdan, F., Li, S., \& Cai, K. (2017). Late Paleozoic closure of the Ob-Zaisan Ocean along the Irtysh Shear zone (NW China): implications for arc amalgamation and oroclinal bending in the Central Asian Orogenic Belt. Geological Society of America Bulletin, 129(5-6), 547-569. https://doi.org/10.1130/B31541.31541.

Liu, Y.-Q., Ji, Q., Kuang, H.-W., Jiang, X.-J., Xu, H., \& Peng, N. (2012). U-Pb zircon age, sedimentary facies, and sequence stratigraphy of the Devonian-Carboniferous boundary, Daposhang Section, Guizhou, China. Palaeoworld, 21(2), 100-107. https://doi.org/10.1016/j.palwor.2012.03.001.

Marynowski, L., Zatoń, M., Racońcinski, M., Filipiak, P., Kurkiewicz, S., \& Pearce, T.J. (2012). Deciphering the upper Famennian Hangenberg Black Shale depositional environments based on multi-proxy record. Palaeogeography, Palaeoclimatology, Palaeoecology, 346, 66-86.

Metcalfe, I. (2011). Palaeozoic-Mesozoic history of SE Asia. Geological Society, London, Special Publications, 355, 7-35. https://doi.org/10.1144/SP355.2.

Nazik, A., Königshof, P., Ariuntogos, M., Waters, J.A., \& Carmichael, S.K. (2021). Late Devonian ostracods from the Hushoot Shiveetiin gol island arc section (Baruunhuurai Terrane, western Mongolia) and their palaeoenvironmental implication and palaeobiogeographic 
relationship. Palaeobiodiversity and Palaeoenvironments, 101(3). https://doi.org/10.1007/s12549-020-00446-z.

Olchowy, P. (2011). Possible origin of stromatactis-like cavities in Upper Jurassic sediments fromthe Wielkanoc quarry near Gocza (Krakow-Czestochowa Upland, southern Poland)experimental studies. Facies, 57(4), 613-625. https://doi.org/10.1007/s10347-010-0262-9.

Paschall, O.C., Carmichael, S.K., Königshof, P., Waters, J.A., Ta, P.H., Komatsu, T., \& Dombrowski, A. (2019). The Hangenberg Event in Vietnam: sustained ocean anoxia with a volcanic trigger? Global and Planetary Change, 175, 64-81. https://doi.org/10.1016/j.gloplacha.2019.01.021.

Percival, L., Davies, J., Schaltegger, U., De Vleeschouwer, D., Da Silva, A.-C., \& Föllmi, K. (2018). Precisely dating the Frasnian-Famennian boundary: implications for the cause of the Late Devonian mass extinction. Scientific Reports, 8(1), 9578.

Pettijohn, F.J., Potter, P.E., \& Siever, R. (1973). Sand and sandstone (Vol. 617). Berlin: Springer-Verlag.

Racki, G. (2005). Toward understanding Late Devonian global events: few answers, many questions. In D.J. Over, J.R. Morrow, \& P.B. Wignall, (Eds.), Understanding Late Devonian and Permian-Triassic Biotic and Climatic Events. Towards an Integrated Approach (Vol. 20, pp. 536). https://doi.org/10.1016/S0920-5446(05)80002-0.

Racki, G. (2019). Volcanism as a prime cause of mass extinctions: retrospectives and perspectives. In T. Adatte, D.P.G. Bond, \& G. Keller, (Eds.), Mass extinctions, volcanism, and impacts: new developments (p. 544). Geological Society of America Special Paper. https://doi.org/10.1130/2019.2544(01.

Racki, G., Rakociński, M., \& Marynowski, L. (2018a). Anomalous Upper Devonian mercury enrichments: comparison of inductively coupled plasma-mass spectrometry (ICPMS) and AAS analytical data. Geology Quarterly, 62(3), 487-495. https://doi.org/10.7306/gq.1419.

Racki, G., Rakociński, M., \& Wignall, P.B. (2018b). Mercury enrichments and the FrasnianFamennian biotic crisis: a volcanic trigger proved? Geology, 46, 543-546. https://doi.org/10.1130/G40233.1.

Ruzhentsev, S.V., Pospeleov, I.I., \& Badarch, G. (1992). Tectonics of Baruunkhuurai Basin, Mongolia. Geotectonics, 22(1), 67-77.

Safonova, I., Kotlyarov, A., Krivonogov, S., \& Xiao, W. (2017). Intraoceanic arcs of the PaleoAsian Ocean. Gondwana Research, 50, 167-194. https://doi.org/10.1016/j.gr.2017.04.005.

Sandberg, C.A., Morrow, J.R., \& Ziegler, W. (2002). Late Devonian sealevel changes, catastrophic events, and mass extinctions. In C. Koeberl, \& K.G. MacLeod, (Eds.), Catastrophic 
events and mass extinctions: impacts and beyond. Boulder, Colorado, Geological Society of America special paper, 356, 473-487.

Sandberg, C.A., Ziegler, W., \& Bultynck, P. (1989). New standard conodont zones and early Ancyrodella phylogeny across the Middle-Upper Devonian boundary. Courier Forschungsinstitut Senckenberg, 110, 195-230. https://doi.org/10.3140/bull.geosci.1623.

Sepkoski, J.J. (1996). Patterns of Phanerozoic extinction: a perspective from global data bases. In O.H. Walliser (Ed.), Global events and event stratigraphy in the Phanerozoic (pp. 35-51). Berlin: Springer-Verlag. https://doi.org/10.1007/978-3-642-79634-0_4.

Song, J.J., \& Gong, Y.M. (2019). Ostracods from the Devonian-Carboniferous transition in Dushan of Guizhou, South China. In W.K. Qie, K. Liang, \& P. Königshof, (Eds). Devonian palaeoecosystems and palaeoenvironment of South China. Palaeobiodiversity and Palaeoenvironments, 99(1), 117-127. https://doi.org/10.1007/s12549-018-0322-7.

Song, H.J., Algeo, T.J., Tong, J.N., Romaniello, S.J., Zhu, Y.Y., Chu, D.L., \& Anbar, A.D. (2017). Uranium and carbon isotopes document global-ocean redox-productivity relationships linked to cooling during the Frasnian-Fammenian mass extinction. Geology, 45, 887-890. https://doi.org/10.1130/G39393.1.

Song, J.J., Crasquin, S., \& Gong, Y.M. (2019). Late Devonian benthic ostracods from western Junggar, NW China: implications for palaeoenvironmental reconstruction. Geological Journal, 54(1), 91-100.

Spalletta, C., Perri, M.C., Over, D.J., \& Corradini, C. (2017). Famennian (Upper Devonian) conodont zonation: revised global standard. Bulletin of Geosciences, 91, 31-57. https://doi.org/10.3140/bull.geosci.1623.

Stachacz, M., Kondas, M., Filipiak, P., \& Ma, X. (2020). Environment and age of the Upper Devonian-Carboniferous Zhulumute and Hongguleleng Formations (Junggar Basin, NW China): Ichnological and Palynological Aspects. Acta Geologica Sinica-English Edition, 1-23. https://doi.org/10.1111/1755-6724.14408.

Stein, W.E., Mannolini, F., Hernick, L.V., Landing, E., \& Berry, C.M. (2007). Giant cladoxylopsid trees resolve the enigma of the Earth's earliest forest stumps at Gilboa. Nature, 446, 904-907. https://doi.org/10.1038/nature05705. 
Suttner, T.J., Kido, E., Chen, X.Q., Mawson, R., Waters, J.A., Frýda, J., Mathieson, D., Molloy, P.D., Pickett, J., Webster, G.D., \& Frýdová, B. (2014). Stratigraphy and facies development of the marine Late Devonian near the Boulongour Reservoir, northwest Xinjiang, China. Journal of Asian Earth Sciences, 80, 101-118. https://doi.org/10.1016/j.jseaes.2013.11.001.

Suttner, T.J., Kido, E., Ariunchimeg, Ya., Sersmaa, G., Waters, J.A., Carmichael, S.K., Batchelor, C.J., Ariuntogos, M., Hušková, A., Slavík, L., Valenzuela-Ríos, J.I., Liao, J.-C., \& Gatovsky, Y.A. (2020). Conodonts from Late Devonian island arc settings (Baruunhuurai Terrane, western Mongolia). Palaeogeography, Palaeoclimatology, Palaeoecology, 549, 1-22. https://doi.org/10.1016/j.palaeo.2019.03.001.

Talent, J.A., \& Mawson, R. (1999). North-eastern Molong Platform and adjacent Hill End Trough, New South Wales: mid Palaeozoic conodont data, age-inferences, and implifications regarding platform exposure and carbonate sedimentation offshore. Abhandlungen der Geologischen Bundesanstalt (Wien), 54, 49-105.

Tucker, M.E. (2001). Sedimentary petrology: an introduction to the origin of sedimentary rocks. Oxford, 3rd edition, 262.

Tucker, M.E., \& Wright, V.P. (1990). Carbonate sedimentology (Vol. 482). Oxford: Blackwell. https://doi.org/10.1002/9781444314175.

Tumurtogoo, O. (2014). Tectonics of Mongolia. In Yu.G. Leonov, O.V. Petrov, \& I.I. Pospelov, (Eds.), Tectonics of northern, central and eastern Asia. Explanatory note to the tectonic map of northerncentral-eastern Asia and adjacent areas at scale 1:2,500,000. SPb.: VSEGEI Printing House, 184.

Vachard, D., Dreesen, R., Marion, J.-M., \& Mottequin, B. (2017). New data on the incertae sedis biota and foraminifera of the mid-Famennian Baelen Member (Late Devonian, eastern Belgium). In B. Mottequin, L. Slavik, \& P. Königshof, (Eds.), Climate change and biodiversity patterns in the mid-Palaeozoic. Palaeobiodiversity and Palaeoenvironments, 97(3), 565-585.

Walliser, O.H. (1996). Global events in the Devonian and Carboniferous. In O.H. Walliser, (Ed.), Global events and event stratigraphy in the Phanerozoic (pp. 225-250). Berlin, Heidelberg: Springer. 
Wang, Z., Becker, R., Aboussalam, Z., Hartenfels, S., Joachimski, M., \& Gong, Y. (2016). Conodont and carbon isotope stratigraphy near the Frasnian/Famennian (Devonian) boundary at Wulankeshun, Junggar Basin, NW China. Palaeogeography, Palaeoclimatology, Palaeoecology, 448, 279-297.

Waters, J.A., Maples, C.G., Lane, N.G., Marcus, S., Liao, Z., Liu, L., Hou, H., \& Wang, J. (2003). A quadrupling of Famennian pelmatozoan diversity: New Late Devonian blastoids and crinoids from northwest China. Journal of Paleontology, 77(5), 922-948. https://doi.org/10.1017/S0022336000044772.

Waters, J.A., Waters, J., Königshof, P., Carmichael, S., \& Ariuntogos, M. (2021). Famennian Crinoids and Blastoids (Echinodermata) from Mongolia. Palaeobiodiversity and Palaeoenvironments, 101(3). https://doi.org/10.1007/s12549-020-00450-3.

Webster, G.D., \& Waters, J.A. (2009). Late Devonian echinoderms from the Hongguleleng Formation of northwestern China. In P. Königshof (Ed.), Devonian change: case studies in Palaeogeography and Palaeoecology, Geological Society of London, special publication (Vol. 314, pp. 263-287). https://doi.org/10.1144/SP314.14.

Wehrmann, A., Hertweck, G., Brocke, R., Jansen, U., Königshof, P., Plodowski, G., Schindler, E., Wilde, V., Blieck, A., \& Schultka, S. (2005). Paleoenvironment of an Early Devonian LandSea transition: a case study from the southern margin of the Old Red Continent (Mosel Valley, Germany). Palaios, 20(2), 101-120. https://doi.org/10.2110/palo.2003.p03-33.

Whatley, R., Pyne, R.S., \& Wilkinson, I.P. (2003). Ostracoda and palaeo-oxygen levels, with particular reference to the Upper Cretaceous of East Anglia. Palaeogeography, Palaeoclimatology, Palaeoecology, 194(4), 355-386. https://doi.org/10.1016/S0031$\underline{0182(03) 00333-X}$.

Wignall, P.B. (2016). The worst of times how life on Earth survived eighty million years of extinctions, Princeton, Princeton University Press, 224.

Wilson, I.G. (1975). Carbonate facies in geologic history (Vol. 471). Berlin: Springer-Verlag. 
Windley, B.F., Alexeiev, D., Xiao, W., Kröner, A., \& Badarch, G. (2007). Tectonic models for accretion of the Central Asian Orogenic Belt. Journal of the Geological Society, 164, 31-47. https://doi.org/10.1144/0016-76492006-022.

Wood, D.A. (1980). The application of a ThHfTa diagram to problems of tectonomagmatic classification and to establishing the nature of crustal contamination of basaltic lavas of the British Tertiary Volcanic Province. Earth and Planetary Science Letters, 50(1), 11-30.

Xiao, W., \& Santosh, M. (2014). The western Central Asian Orogenic Belt: a window to accretionary orogenesis and continental growth. Gondwana Research, 25(4), 1429-1444. https://doi.org/10.1016/j.gr.2014.01.008.

Xiao, W.J., Huang, B.C., Han, C.M., Sun, S., \& Li, J.L. (2010). A review of the western part of the Altaids: a key to understanding the architecture of accretionary orogens. Gondwana Research, 18(2-3), 253-273. https://doi.org/10.1016/j.gr.2010.01.007.

Yang, G., Li, Y., Santosh, M., Yang, B., Zhang, B., \& Tong, L. (2013a). Geochronology and geochemistry of basalts from the Karamay ophiolitic mélange in West Junggar (NW China): implications for Devonian-Carboniferous intra-oceanic accretionary tectonics of the southern Altaids. Geological Society of America Bulletin, 125(3-4), 401-419. https://doi.org/10.1130/B30650.1.

Yang, G., Li, Y., Santosh, M., Yang, B., Zhang, B., \& Tong, L. (2013b). Geochronology and geochemistry of basalts the Karamay ophiolitic mélange in West Junggar (NW China): implications for Devonian-Carboniferous intra-oceanic accretionary tectonics of the southern Altaids. Geological Society of America Bulletin, 125(3-4), 410-419. https://doi.org/10.1130/B30650.1.

Yang, G., Li, Y., Tong, L., \& Yang, B. (2015). Oceanic Island Basalts from the Darbut and Karamay Ophiolitic Mélange in West Junggar (NW China): product of a Middle Devonian mantle plume? Acta Geologica Sinica, 89, 105-106. https://doi.org/10.1111/17556724.12308_63.

Yang, G., Li, Y., Tong, L., Wang, Z., Duan, F., Xu, Q., \& Li, H. (2019). An overview of oceanic island basalts in accretionary complexes and seamounts accretion in the western Central Asian Orogenic Belt. Journal of Asian Earth Sciences, 179, 385-398. https://doi.org/10.1016/j.jseaes.2019.04.011. 
Yazdi, M. (1999). Late Devonian-Carboniferous conodonts from eastern Iran. Rivista Italiana di Paleontologica e Stratigrafia, 105, 167-200.

Ziegler, W., \& Sandberg, C.A. (1984). Palmatolepis based revision of upper part of Standard Late Devonian conodont zonation. In D.L. Clark, (Ed.), Conodont biofacies and provincialism, Geological Society of America, 196, 179-194.

Zong, K., Chen, J.Y., Hu, Z., Liu, Y., Li, M., Fan, H.F., \& Meng, Y.N. (2015). In-situ U-Pb dating of uraninite by fs-LA-ICP-MS. Springer-Science China Earth Science, 58(10), 17311740. https://doi.org/10.1007/s11430-015-5154-y. 


\title{
Chapter 3 - Late Devonian (Famennian) phacopid trilobites from western Mongolia
}

Crônier, C. ${ }^{1}$, Ariuntogos, M. ${ }^{2,3}$, Königshof, P. ${ }^{2}$, Waters, J.A. ${ }^{4}$, Carmichael, S.K. ${ }^{4}$

(1) Université de Lille, CNRS, UMR 8198 Évo-Éco-Paléo, F-59000 Lille, France

(2) Senckenberg Research Institute and Natural History Museum, Senckenberganlage 25, 60325

Frankfurt, Germany

(3) Mongolian University of Science and Technology, Baga Toiruu, Sukhbaatar District, Ulaanbaatar, Mongolia

(4) Department of Geological and Environmental Sciences, Appalachian State University, 572 Rivers St., Boone, NC 28608, USA

Published in Palaeobiodiversity and Palaeoenvironments, Received: 29 May 2020 /Revised: 22 July 2020 /Accepted: 23 July 2020, https://doi.org/10.1007/s12549-020-00449-w.

\begin{abstract}
The early Famennian phacopid trilobites Feistops mongoliensis gen. nov. sp. nov., Feistops khovdensis gen. nov. sp. nov., ?Feistops sp. A, and ?Houseops olonbulagensis sp. nov. are recorded and illustrated from the western Mongolia Hushoot Shiveetiin gol section from the Baruunhuurai Terrane of the Central Asian Orogenic Belt (CAOB). In this section, exposing large parts of cyclic Famennian shallow-water siliciclastic shelf deposits, Feistops mongoliensis gen. nov. sp. nov., Feistops khovdensis gen. nov. sp. nov., ?Feistops sp. A, and ?Houseops olonbulagensis sp. nov. are the first known and described representatives of trilobites from Late Devonian deposits of western Mongolia. Their affinities with known other sighted species of the same age are discussed.
\end{abstract}

Keywords: Central Asian Orogenic Belt (CAOB), Trilobites, Phacopidae, Devonian, Palaeobiogeography, Biodiversity hotspot

\section{Introduction}

A major goal in macroevolution is to understand patterns of diversity fluctuations in organisms. Among organisms, according to their taxonomic, morphological, and behavioral diversity, trilobites constitute a model to study such diversity evolution (Crônier 2010). Trilobites were relatively abundant and diverse in marine habitats in the mid-Palaeozoic, a time of dynamic long term climate change (Algeo and Scheckler 1998; Stein et al. 2007; Becker et al. 2016) triggering significant biodiversity changes and major biotic crisis (Sepkoski 1996; Racki 2005; Bond and Grasby 2017). In particular, the Late Devonian period is important for the development of the phacopid trilobites because the main groups of reduced eyed or blind phacopids arose at that time, especially in deeper offshore cephalopod limestones, after a severe diversity restriction triggering one of the highest extinction rates in the Late Palaeozoic (Lerosey-Aubril and Feist 2012; Crônier et al. 2013; Crônier and François 2014). The trilobite record remains scarce in shallow near-shore environments due to relatively few studies dealing with shallow-water sections. Recently, Feist (2019) made a challenge to update and revise both known and new postevent early Famennian phacopids, with respect to their systematic definition and their 
biostratigraphical assignment within the conodont zonation. He recognized a rather important post-event recovery and diversification of phacopids during the early Famennian (Early triangularis through Early marginifera conodont biozones) with 11 genera and 38 species versus only 6 genera and 12 species during the Frasnian.

In shallow near-shore environments, if previous works on organisms that expand from shallowwater habitats such as echinoderms, bryozoans, and ostracods (Waters et al. 2003; Waters and Webster 2009; Ernst 2013; Waters et al. 2021; Nazik et al. 2021) point out that the Central Asian Orogenic Belt and neighboring areas acted as a diversity hotspot during the Famennian, nothing has been identified for trilobites. Such a diversity hotspot may be related to specific palaeoenvironmental settings (Waters et al. 2003; Waters and Webster 2009; Ernst 2013; Waters et al. 2021; Nazik et al. 2021). Moreover, Ariunchimeg et al. (2014) through their marine macrofossil overview from the Baruunhuurai Terrane documented a high diversity and abundant organisms throughout the Frasnian/Famennian interval, and illustrated some phacopid trilobite remains.

To evaluate the hypotheses that specific palaeoenvironmental settings or areas could be validated as refugia or radiation centers for trilobite faunas, both during and in the aftermath of global Late Devonian extinction events, a systematic trilobite study has been performed from a shallow-water section. In particular, a focus was on an under-explored area in western Mongolia in order to better expand our knowledge regarding the Devonian trilobite biodiversity and its related events.

Hitherto, only the northern Canning Basin in Western Australia on the southeastern margin of Gondwana offered a diverse fauna of early Famennian oculated phacopids from reef-slope environments (Feist et al. 2009). This fauna expanding fromshallow-water habitats support the idea of this specific palaeoenvironmental setting as refugia, and the origin of post-event phacopids from shallow water environments is demonstrated for the first time (Feist et al. 2009).

The present paper contributes to the systematic study of the Upper Devonian phacopids. The discovery of new occurrences assigned to Feistops mongoliensis gen. nov. sp. nov., Feistops khovdensis gen. nov. sp. nov., ?Feistops sp. A, and ?Houseops olonbulagensis sp. nov. from western Mongolia provides the opportunity to get a better understanding of these forms and their palaeoenvironmental setting. These phacopines lend a particular dimension to the Upper Devonian trilobite fauna; they are among the youngest representatives of phacopines, and those with the high number of ocular lenses (Crônier et al. 2011). No members of other trilobite families have been found associated with the studied phacopids at this stage of the investigations.

\section{Geological setting and material}

The Central Asian Orogenic Belt (CAOB) associated with the closure of a part of the PalaeoAsian Ocean prior to the end of the Carboniferous covers a huge area that extends between the Siberian platform and the Cathaysian terranes (Fig. 1a). CAOB includes a complex 
amalgamation of intra-oceanic island arcs and continental margin arc terranes including Palaeozoic deposits of western Mongolia as part of this complex tectonic framework (Xiao et al. 2010; Xiao and Santosh 2014; Li et al. 2017; Yang et al. 2019).

a
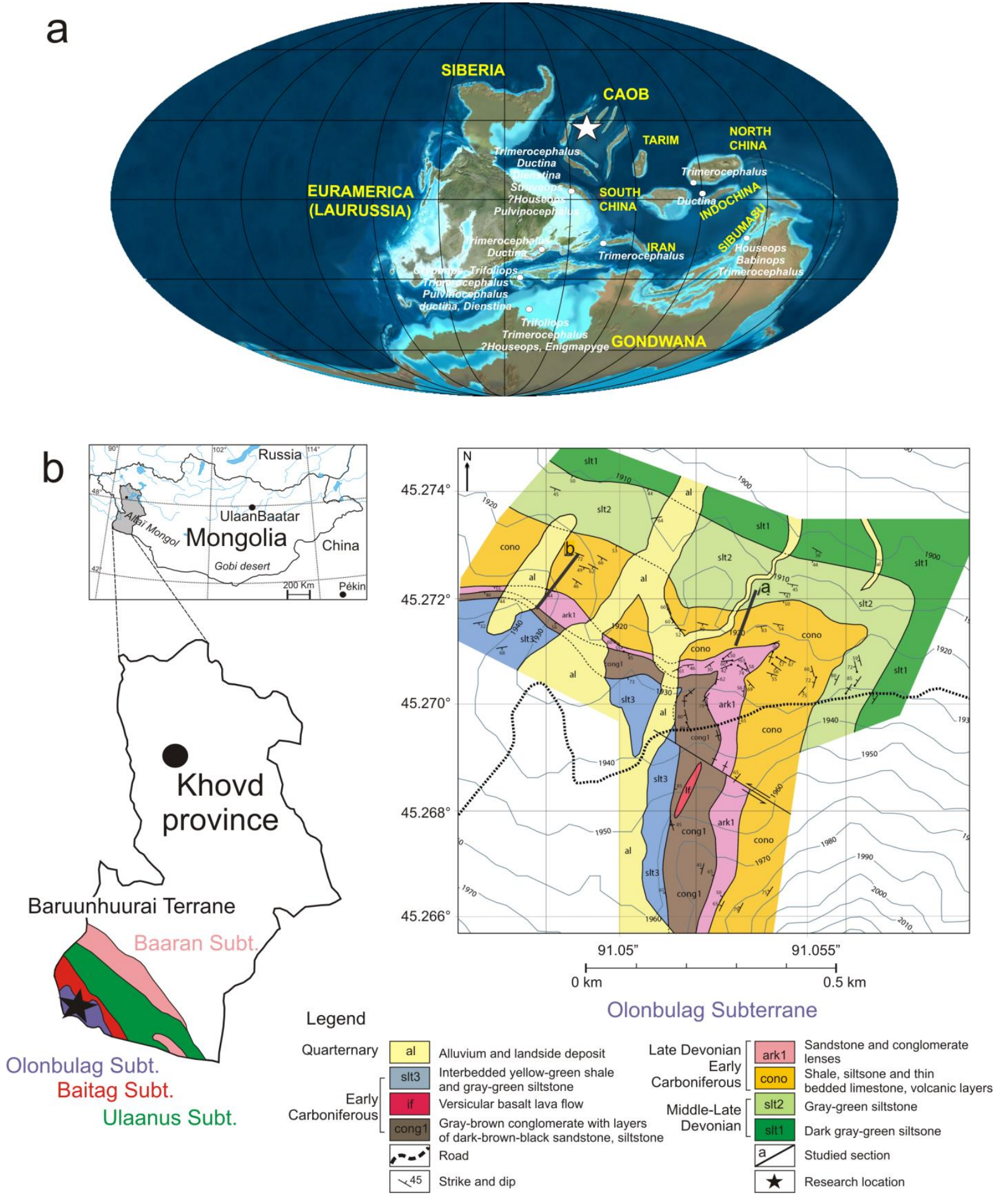
Fig. 1 a Location of the Central Asian Orogenic Belt (CAOB) on a palinspastic map (http://www.palaeos.com) (modified from Blakey (2016), with continent positions and shapes modified from the tectonic data of Hara et al. (2010), Metcalfe (2011), and Xiao et al. (2010); trilobite assemblages modified from Crônier and François (2014)). b Geographical location of the Khovd province, western part of Mongolia, and location of studied section in the Olonbulag Subterrane exhibiting mid-Palaeozoic deposits of the Baruunhuurai Terrane. Geological map of the investigated area: "a" eastern and "b" western Hushoot Shiveetiin gol section (from Munkhjargal et al. 2021).

The mid-Palaeozoic deposits well-developed in the Baruunhuurai Terrane are located in the western part of Mongolia, the Baruunhuurai Terrane being subdivided in three or four subterranes (Badarch et al. 1998; Dergunov 2001; Ariunchimeg et al. 2014; Safonova et al. 2017). The Devonian material originates from a section located in the Olonbulag Subterrane (Fig. 1b) and belonging to the Samnuuruul Formation. The Hushoot Shiveetiin gol section has a total thickness of approximately $150 \mathrm{~m}$ and is divided in an eastern and in a western section (Munkhjargal et al. 2021). The section (Fig. 2) is characterized by shallow-shelf mixed siliciclastic/carbonate facies with distinct fossiliferous horizons and frequently intercalated volcaniclastic rocks (Bolshakova et al. 2003; Kido et al. 2013; Ariunchimeg et al. 2014; Suttner et al. 2019; Munkhjargal et al. 2021). Sedimentary analysis indicates variable facies settings ranging from shallow-intertidal to open marine (for detailed facies analysis, we refer to Munkhjargal et al. 2021). The section is of Famennian to Early Mississippian age and ranges from the Palmatolepis minuta minuta conodont Biozone to at least the Palmatolepis rugosa trachytera conodont Biozone (zonation follows Hartenfels (2011) and Spalletta et al. (2017)).

The collected trilobite material assigned to the Phacopidae family is the result of a field campaign in 2018. Phacopids include disarticulated molting remains as well as partially enrolled specimens. Phacopid remains are more or less well-preserved with some distortion due to some abrasion features as a result of sediment transport. The trilobite content with their geographic and stratigraphic locations is listed in Fig. 3. The material described and figured herein is stored at the Mongolian University of Sciences and Technology, Ulaanbaatar, Mongolia, under repository numbers MUST-RCSP-TRI.-0001 to 0016.

\section{Systematic palaeontology (by C. Crônier)}

The illustrated specimens were coated with ammonium chloride before photographed using a digital camera Nikon. The morphological terminology follows Chlupáč (1977) and Crônier et al. (2011).

Order Phacopida Salter 1864

Superfamily Phacopoidea Hawle and Corda 1847

Family Phacopidae Hawle and Corda 1847

Subfamily Phacopinae Hawle and Corda 1847 

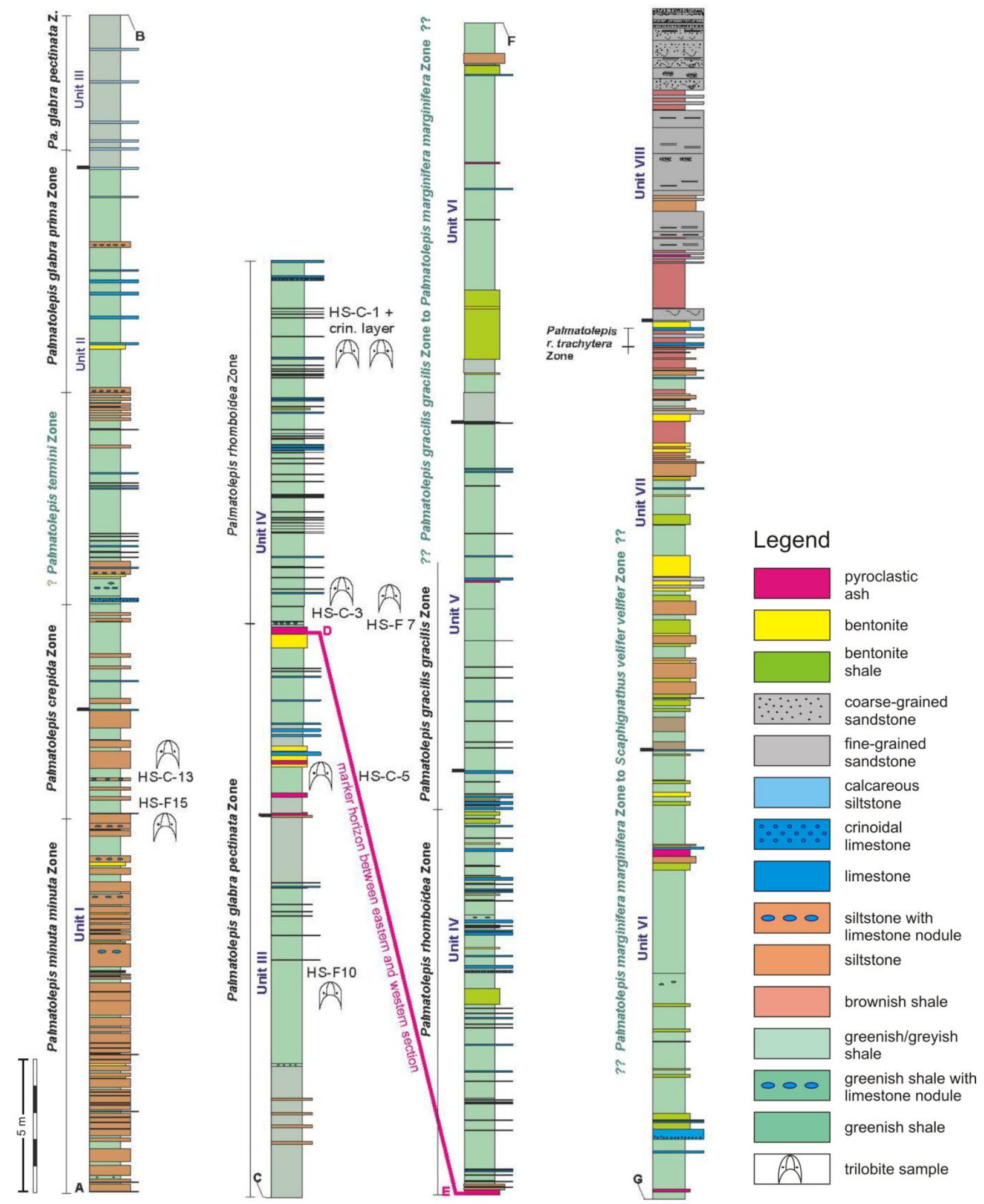

Fig. 2 Lithological log, stratigraphical range, and trilobite levels of the Hushoot Shiveetiin gol section, western Mongolia. The figure is changed after Munkhjargal et al. 2021. 


\section{Genus Feistops gen. nov.}

Type species: Feistops mongoliensis gen. nov. sp. nov.

Species included: Type species: Famennian (Palmatolepis crepida to Palmatolepis glabra pectinata conodont biozones), western Mongolia; Feistops khovdensis gen. nov. sp. nov.: Famennian (Palmatolepis rhomboidea conodont Biozone), western Mongolia.

Species tentatively assigned: ?Feistops sp. A: Famennian (Palmatolepis rhomboidea conodont Biozone), western Mongolia.

Etymology: For Raimund Feist (Montpellier, France), in honor of all his work on Late Devonian trilobites.

Diagnosis: Glabella lowered with a narrow base, subangular anterolateral angles, and deep axial furrows; S2 and S3 absent; wide and inflated median portion of L1 relative to its total width; wide $\mathrm{L} 0$ with no defined lateral lobes; reniform visual complex with $15-16$ vertical lens files and maximum five or six lenses per file; postocular genal field length equals length of posterior border; subocular librigenal field narrow at the front of the eye, becoming larger and concave backwards; no marginulation. Pygidium rather wide with a narrow pygidial axis, composed of 67 clear rings plus terminal piece; pygidial pleural field with 5-6 well-defined ribs; deep pleural furrows; indistinct interpleural furrow. Tubercles on cephalon.

Stratigraphical range: Early Famennian.

Occurrence: Western Mongolia.

Remarks: The configuration of cephalic and pygidial features assign the new taxon to the Phacopidae. However, the following set of features combined observed in the type species, i.e., the lowered glabella with anterior cephalic border forwardly extending beyond anterior outline of glabella, the reniform visual complex close to the posterior border, and the configuration of the curved cephalic doublure long (sag.) and rather deep, not seen in any other early Famennian phacopids, justify its assignment to the new genus. Only the large-eyed phacopine Magreanops monachus van Viersen and Vanherle 2018 from the middle Frasnian of Belgium that shows a number of similar dorsal cephalic traits differ in having a longer (sag.) eye (see next "comparison" section).

Feistops mongoliensis gen. nov. sp. nov.

Fig. $4(1-13)$

Etymology: After the area of western Mongolia.

Holotype: Cephalon, MUST-RCSP-TRI.-0001 (Fig. 4 (1-5)). 
Paratype: Pygidium, MUST-RCSP-TRI.-0002 (Fig. 4 (6)).

Type locality: Hushoot Shiveetiin gol section, the Baruunhuurai Terrane, Olonbulag Subterrane, western Mongolia.

Type stratum: Samnuuruul Formation, Famennian (thin-bedded marly limestone), Palmatolepis glabra pectinata conodont Biozone, Late Devonian.

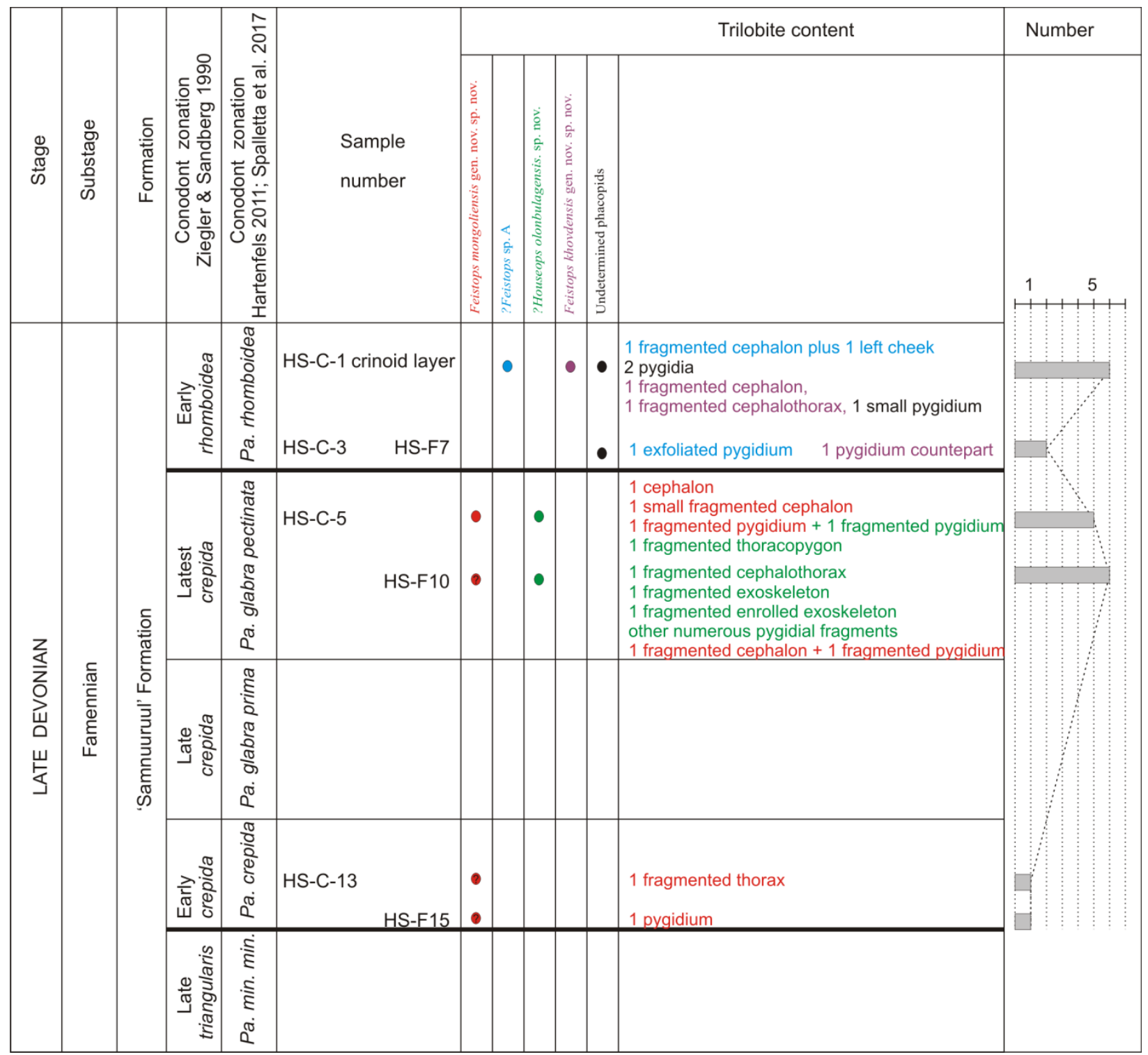

Fig. 3 Lithostratigraphic column of the 'Samnuuruul' Formation and stratigraphical location of studied phacopid trilobites from Hushoot Shiveetiin gol section.

Material: Holotype, one small fragmented cephalon, and one fragmented and mostly exfoliated pygidium from HS-C-5 (4d); one fragmented cephalon and one fragmented pygidium from HS- 
F10 (Palmatolepis glabra pectinata conodont Biozone). Possibly one poorly preserved thorax from HS-C-13 and one pygidium from HS-F15 (Palmatolepis crepida conodont Biozone).

Diagnosis: Cephalon narrow; glabella bounded by moderately divergent axial furrows; L1 with few tubercles; reniform visual complex with 15 vertical lens files and maximum five lenses per file; inter-lensar sclera thickened dorsally and more lightly ventrally; inflated palpebral lobe; palpebral furrow distinct and convex (abax.). Pygidium rather wide with a narrow pygidial axis, composed of 6-7 clear rings plus terminal piece; pygidial pleural field with 5-6 well-defined ribs; deep pleural furrows; indistinct interpleural furrow. Medium-sized to fine tubercles distinct and moderately dense on cephalon.

Description: Cephalon: narrow, length/width ratio about 0.66. Dorsal view: glabellar ratio of width at L1/maximum width of frontal lobe about 0.46 , narrow at base. Glabella lowered, bounded by relatively deep axial furrows that are moderately divergent $\left(66^{\circ}\right)$. Frontal outline, parabolic anteriorly. Frontal lobe hardly overhanging a deep preglabellar furrow. S2 and S3 indistinct. S1 continuous and hardly curved in its middle part, subparallel to S0, and becoming deeper in its distal portions. L1 shorter (sag.) than L0 (more than half-length of L0) and with a wide (tr.) median portion relative to its total width. Median portion of L1 inflated, with tubercles. L1 with subcircular/subquadrate lateral lobes separated from its median part by a weak exsagittal furrow. S0, distinct and almost transverse/ hardly curved in its middle portion. L0 wide (tr.) with lateral lobes not defined. Reniform visual surface with 15 dorso-ventral files of lenses (only 12 for the small cephalon) and a maximum of 5 lenses per file, with smaller lenses in the anterior part. Inter-lensar sclera thickened dorsally and more lightly ventrally. Palpebral furrow distinct and strongly convex (abax.). Exsagittal length of the postocular genal field, equal length (exsag.) of the posterior border. Lateral view: glabella sloping obliquely and then dorsoventrally in its anterior part. Outline of L1 curved. L0 as high as glabella at its maximum convexity. Anterior border, relatively short, forming a border projected forward and sloping posteroventrally. Marginulation no visible. Posterior border furrow deep and narrow. Lateral border furrow moderately narrow and shallow at the front of the eye, becoming shallower towards the back. Subocular librigenal field very narrow at the front of the eye, becoming larger and concave backwards with no subocular pad. Posterolateral border furrow shallow (continuous on the internal mold) and posterolateral border widening at the genal angle. Frontal view: glabellar outline semicircular becoming oblique laterally (divergence of $57^{\circ}$ ). Palpebral area inflated and as high as the inflated palpebral lobe. Ventral view: vincular furrow relatively deep and wide (sag.), broadly and evenly curved. Posterior band of the cephalic doublure long (sag.), with a hypostomal suture slightly convex backward medially. Pygidium: mostly exfoliated. Rather wide with a length/width ratio about $47 \%$ (excluding the half ring), and its maximum width (tr.) in front of its mid-length (sag.) in dorsal view. Posterior outline roughly broadly rounded. Pydigial axis very long (sag.) and rather narrow (tr.), weakly tapered, with rather incomplete terminal closure. Seven distinct rings in the pygidial axis. Pygidial pleural field with 5-6 distinct ribs delimited by deep pleural furrows. Interpleural furrows indistinct. Pseudo-articulating half rings 

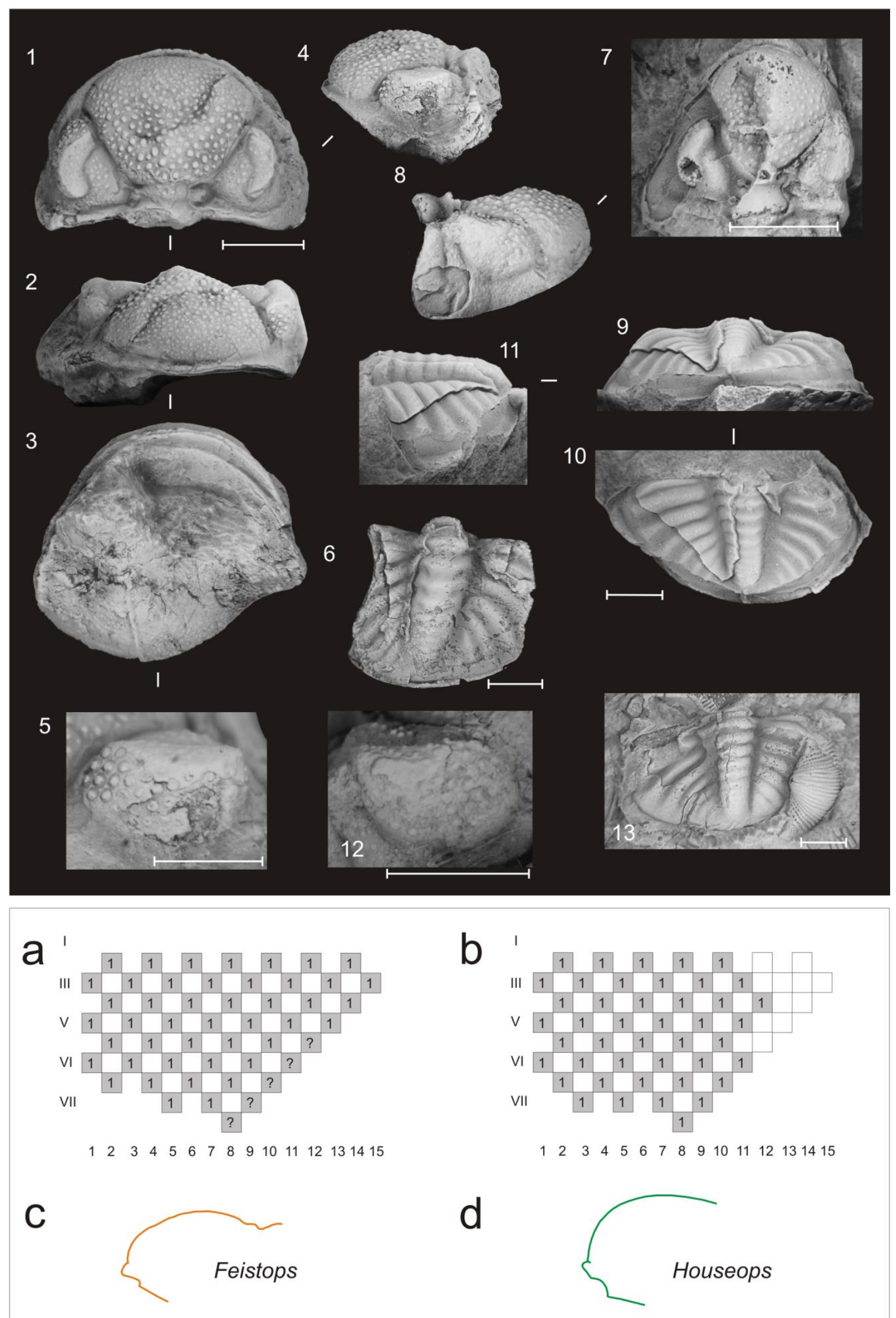
Fig. 4 Phacopid trilobites from the Baruunhuurai Terrane, Olonbulag Subterrane, western Mongolia. (1-5) Feistops mongoliensis gen. nov. sp. nov., Hushoot Shiveetiin gol section (bed HS-C-5, Palmatolepis glabra pectinata conodont Biozone), Holotype, MUST-RCSP-TRI.-0001, cephalon, respectively, in dorsal, frontal, ventral and lateral views, and detail of the left eye. (6) Feistops mongoliensis gen. nov. sp. nov., Hushoot Shiveetiin gol section (bed HS-C-5, Palmatolepis glabra pectinata conodont Biozone), MUST-RCSP-TRI.-0002, fragmented pygidium in dorsal view. (7-8, 12) Feistops mongoliensis gen. nov. sp. nov., Hushoot Shiveetiin gol section (bed HS-F10, Palmatolepis glabra pectinata conodont Biozone), MUST-RCSP-TRI.-0003, cephalon, respectively, in dorsal, lateral views, and detail of the right eye. (9-11) Feistops mongoliensis gen. nov. sp. nov., Hushoot Shiveetiin gol section (bed HS-F10, Palmatolepis glabra pectinata conodont Biozone), MUST-RCSP-TRI.-0004, pygidium, respectively, in frontal, dorsal and lateral views. (13) Feistops mongoliensis gen. nov. sp. nov., Hushoot Shiveetiin gol section (bed HS-F15, Palmatolepis crepida conodont Biozone), MUST-RCSP-TRI.-0005, pygidium in dorsal view. Scale: $3 \mathrm{~mm}$ (except 5 and 12: $2 \mathrm{~mm}$ ). Schematic representation of a a visual surface in Feistops mongoliensis gen. nov. sp. nov., Holotype, MUST-RCSP-TRI.-0001; b a visual surface in Feistops mongoliensis gen. nov. sp. nov., MUST-RCSP-TRI.-0003; c a sagittal profile of anterior part of cephalon in Feistops mongoliensis gen. nov. sp. nov., Holotype, MUST-RCSP-TRI.-0001; d a sagittal profile of anterior part of cephalon in Houseops illustrated in Feist 2019. I-VII: horizontal rows; 1-15 (from the front): vertical files. Grey boxes indicate number of lens present.

very weakly suggested by expanded inter-rings furrows. Sculpture: cephalon covered with medium-sized to fine tubercles of rather heterogeneous size, moderately dense on entire composite lobe. Few small pits added to tubercles on the palpebral lobe. Posterior band of the cephalic doublure and pygidium showing no evidence of sculpture.

Comparison: The holotype is relatively well-preserved and almost complete. There is a slight collapse of the left anterior part of the glabella, but the glabella remains lowered. The left lateral border is damaged, which induced visually an asymmetry. However, the characters observed and discussed in the description seem to be present. The small associated cephalon is unfortunately poorly preserved and prevent us to complete the description. Nevertheless, Feistops gen. nov. differs from all other known sighted genera of the same age worldwide. Feistops mongoliensis gen. nov. sp. nov. differs from Nephranops Richter and Richter 1926 from the middle triangularis to early crepida, i.e., Palmatolepis crepida conodont Biozone according to Spalletta et al. 2017, that is characterized by a low kidney-shaped palpebral lobes with a visual surface generally without lenses or only with residual lenses. Feistops mongoliensis shares with Nephranops a pygidium with a narrow and long axis composed of 7-9 rings, not reaching the posterior margin.

Feistops mongoliensis differs from Pulvinocephalus Feist 2019 from early triangularis to early marginifera, i.e., Palmatolepis marginifera marginifera conodont Biozone according to Spalletta et al. (2017), that is characterized by a reduced-eyed visual surface or blind and with an anterior cephalic border forwardly extending beyond the anterior outline of glabella.

Feistops mongoliensis differs from Cryphops Richter and Richter 1926 from middle to late crepida, i.e., Palmatolepis glabra prima conodont Biozone according to Spalletta et al. (2017), that is characterized by an elliptical visual surface with 7-11 lenses, a very broad (sag.) and slightly vaulted previncular doublure inclined posteroventrally, a deep and long (sag.) vincular furrow bordered by sharp edges and without post-vincular doublure. 
Feistops mongoliensis differs from Babinops Feist and Becker 1997 from late crepida to rhomboidea that is characterized by genal spine or reducing to pointed genal angle, and a cephalic doublure without vincular furrow. This obsolescence of the vincular furrow is also observed in the contemporaneous phacopidelline taxa Ductina Richter and Richter 1931 and Dienstina Richter and Richter 1931. However, Feistops mongoliensis shares with Babinops minor Feist et al. 2009 a low convex glabella not overhanging anterior border, a short postocular distance, kidney-shaped palpebral lobes and a similar visual surface in size: 16 dorsoventral lens files in Babinops minor against 15 in Feistops mongoliensis, a maximum of five lenses in each file in both taxa, and maximum total number of lenses 61 in Babinops minor against 50 in Feistops mongoliensis.

Feistops mongoliensis shares with Houseops Feist et al. 2009 from late triangularis to late crepida, i.e., Palmatolepis glabra prima conodont Biozone according to Spalletta et al. (2017), a relatively subdued transverse cephalic profile, not impressed S2 and S3 glabellar furrows, and a relatively flat glabella. Feistops mongoliensis differs from Houseops that is characterized by smaller eyes distant from the posterior margin, weak palpebral furrows, flat palpebral lobes, a flat and short post-vincular area, and an ornamentation consisting of thin and sparse tubercles.

?Houseops nalivkini (Maksimova 1955) from the early Famennian (possibly triangularis to marginifera) of the Southern Urals has been tentatively assigned to Houseops by Feist et al. (2009) mainly on account of the retracted anterior outline of its low glabella and the narrow and posteriorly pointed pygidial axis. Because of these characters, Feistops mongoliensis resembles ?H. nalivkini. However, Feistops mongoliensis differs from ?H. nalivkini by its not inflated abaxially postocular area, a narrower (tr.) cephalon, its more recurved anterolateral corners of the glabella, and its coarser tuberculation.

The new species shows some morphological features of ?Houseops tamtertensis described by Crônier, 2013 in Crônier et al. (2013) from the Famennian (rhomboidea) of Algeria such as a narrow cephalon with coarse conical tubercles, similar anterolateral corners of the glabella. However, ?Houseops tamtertensis differs from Feistops mongoliensis by its lowered glabella with a wide base and a frontal outline slightly tapered, a visual complex with only 13 dorsoventral lens files and maximum 3 lenses per file, and a palpebral furrow almost transverse.

The new species resembles Phacops granulatus (Münster 1840) from the Famennian of Europe (Germany, Silesia, Poland, Moravia, Austria, England, Spain, Portugal) and North Africa (Algeria, Morocco), but also encountered in the Urals, Kazakhstan, China, and Iran on account of its narrow cephalon, a visual surface with 15 vertical files and both palpebral area and palpebral lobe about same level in height. However, Phacops granulatus differs in having a broader (tr.) and inflated glabella pointed anteriorly, a palpebral furrow less convex (abax.), a longer exsagittal length of the postocular genal field, and dense homogeneous tubercles on glabella. 
The new species shares a glabella and cheeks little inflated a lack of ornamentation on the cephalic doublure with Phacops tafilaltensis Crônier and Clarkson 2001. However, Phacops tafilaltensis differs in having a broader (tr.) cephalon, and a visual surface much longer (18 vertical files, $4-5$ lenses per file).

The new species also resembles Rabienops wedekindi (Richter and Richter 1926) from the late Famennian because of its narrow cephalon and fine homogeneous tubercles on glabella. However, Rabienops wedekindi differs in having a broader (tr.) glabella and a shorter visual surface with only 13 vertical lens files with four maximum lenses per file.

By comparison with trilobite faunas from closely areas such as the Xinjiang, Northwest China where the genus Omegops Struve 1976 has been encountered in the late Famennian (Xiang 1981; Yuan and Xiang 1998), Feistops mongoliensis differs from Omegops mobilis (Xiang 1981) or O. ?cornelius (Richter and Richter 1933) that are characterized by a reduced intercalating ring as a narrow flat band, a distinct postocular pad, a marginulate lateral border, and coarse tubercles on glabella. Feistops mongoliensis shares with Omegops a visual surface with 15-16 dorso-ventral files.

The new species resembles Magreanops monachus van Viersen and Vanherle 2018 from the Frasnian of Belgium because of its lowered glabella with a narrow base, its lack of S2 and S3, its wide L0 and its shape and distribution of glabellar tubercles. Nevertheless, Magreanops monachus differs in having a longer (sag.) eye (18 dorso-ventral files with a maximum of 8-9 lenses per file in M. monachus versus 15 dorso-ventral files with a maximum of 5 lenses per file in Feistops mongoliensis), no subocular area, and a glabellar outline semicircular becoming oblique laterally with a divergence of $27^{\circ}$ in frontal view ( $57^{\circ}$ in Feistops mongoliensis). Due to the similar dorsal cephalic features, Feistops could be a potential descendant of Magreanops.

Feistops khovdensis gen. nov. sp. nov.

Fig. $5(1-3,10-11)$

Holotype: Cephalon, MUST-RCSP-TRI.-0006 (Fig. 5 (1-3)).

Paratype: Cephalothorax, MUST-RCSP-TRI.-0007 (Fig. 5 (10-11)).

Type locality: Hushoot Shiveetiin gol section, the Baruunhuurai Terrane, Olonbulag Subterrane, western Mongolia

Type stratum: Samnuuruul Formation, Famennian (thin-bedded limestone), Palmatolepis rhomboidea conodont Biozone, Late Devonian.

Material: One cephalon MUST-RCSP-TRI.-0006 and a fragmented cephalothorax MUSTRCSP-TRI.-0007 (Fig. 5 (1-3, 10-11)). 
Diagnosis: Cephalon very wide; glabella bounded by high divergent axial furrows; slightly inflated median portion of L1 with few subdued tubercles; reniform visual complex with 15-16 vertical lens files and maximum six lenses per file; thin inter-lensar sclera; subdued palpebral lobe; palpebral furrow weak and convex (abax.). Subdued and dense fine-sized tubercles on cephalon.

Description: Cephalon: wide, length/width ratio about 0.50. Dorsal view: glabellar ratio of width at L1/maximum width of frontal lobe about 0.44, narrow at base. Glabella lowered bounded by relatively deep axial furrows that are highly divergent $\left(73^{\circ}\right)$. Frontal outline broadly parabolic anteriorly. Frontal lobe hardly overhanging a distinct preglabellar furrow. S2 and S3 indistinct. S1 continuous and hardly curved in its middle part, subparallel to S0, and becoming deeper in its distal portions. L1 shorter (sag.) than L0 (half-length of L0) and with a wide (tr.) median portion relative to its total width. Median portion of L1 slightly inflated, with few tubercles. L1 with subcircular lateral lobes separated from its median part by a distinct exsagittal furrow. S0 distinct and almost transverse/ hardly curved in its middle portion. L0 relatively wide (tr.) with lateral lobes not defined. Reniform visual surface with 15-16 dorso-ventral files of lenses and a maximum of 6 lenses per file. Inter-lensar sclera thin. Palpebral furrow weak and convex (abax.). Exsagittal length of the postocular genal field equal length (exsag.) of the posterior border. Lateral view: glabella sloping dorsoventrally in its anterior part. Outline of L1 curved. L0 as high as glabella at its maximum convexity. Anterior border relatively short, forming a border projected forward and sloping posteroventrally. Marginulation no visible. Posterior border furrow deep and narrow. Lateral border furrow wide and shallow backwards. Subocular librigenal field narrow at the front of the eye, becoming larger and concave backwards with no subocular pad. Posterolateral border furrow almost effaced and posterolateral border widening at the genal angle. Frontal view: glabellar outline semicircular becoming oblique laterally (divergence of $80^{\circ}$ ). Palpebral area inflated and higher than the subdued palpebral lobe. Ventral view: not available. Thorax: axial rings convex without defined lateral lobes. Axial furrows distinct. Anterior pleural band narrower (exsag.) than the posterior pleural band. Pleural furrows narrow and deep. Sculpture: cephalon covered with fine subdued tubercles of rather homogeneous size, dense on entire composite lobe. Thoracic rings showing similar sculpture. There is no evidence of sculpture on the lateral border (mostly eroded or damaged).

Comparison: The new species is represented by a complete and relatively well-preserved cephalon but probably exposed to a dorso-ventral distortion (inducing an elevation of lateral border and leading to a wider cephalon than reality) and a fragmented cephalothorax providing us an almost complete description, except for pygidium. Feistops khovdensis gen. nov. sp. nov. shares with Feistops mongoliensis gen. nov. sp. nov.: a subdued glabella with a narrow base and subangular anterolateral angles, similar axial furrows in shape (i.e., sligthly sigmoidal) and depth (deep between S1 and front of palpebral furrow), a wide and inflated median portion (tr.) of L1 relative to its total width (tr.), no S2 and S3, no marginulation, an almost effaced lateral border 


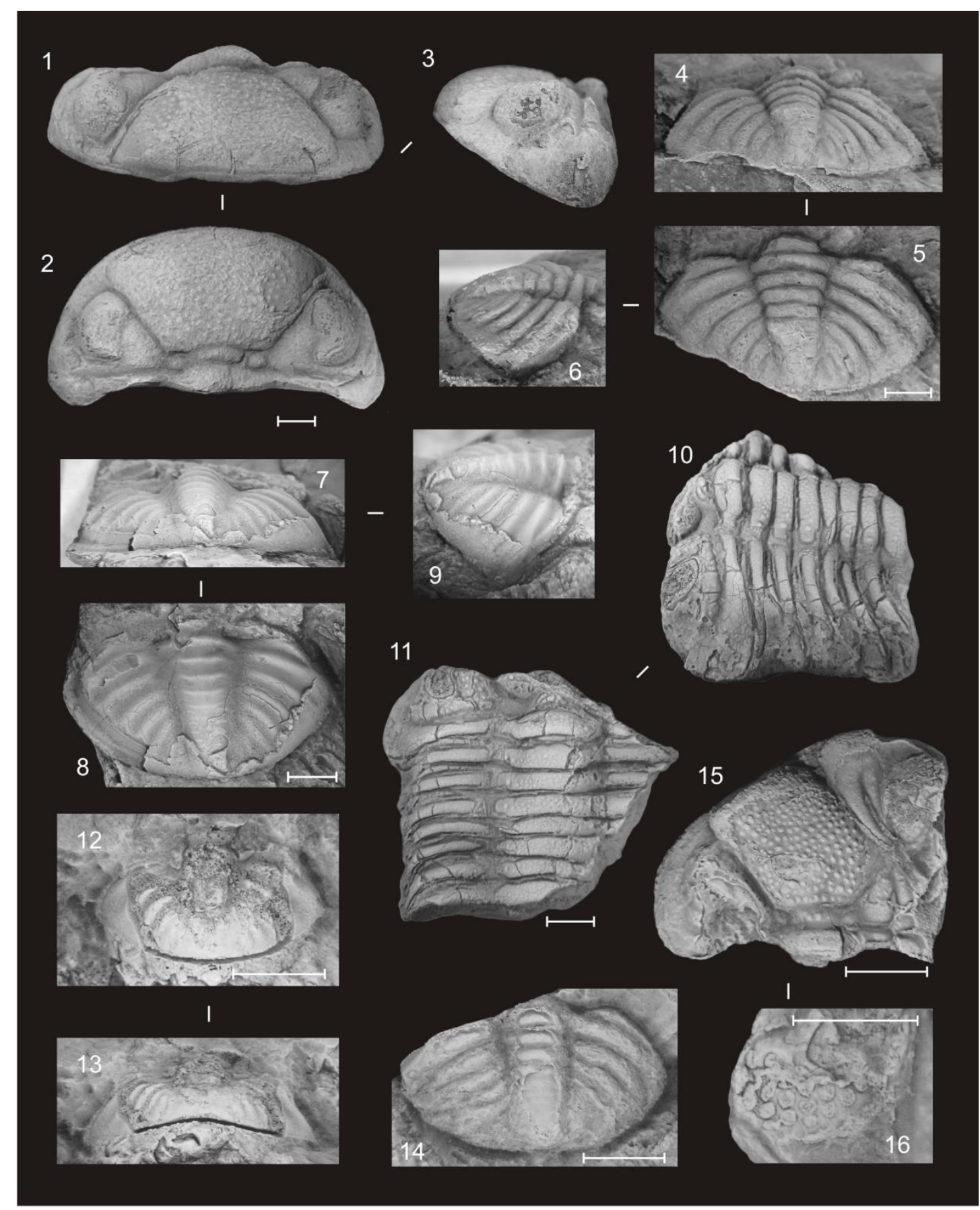

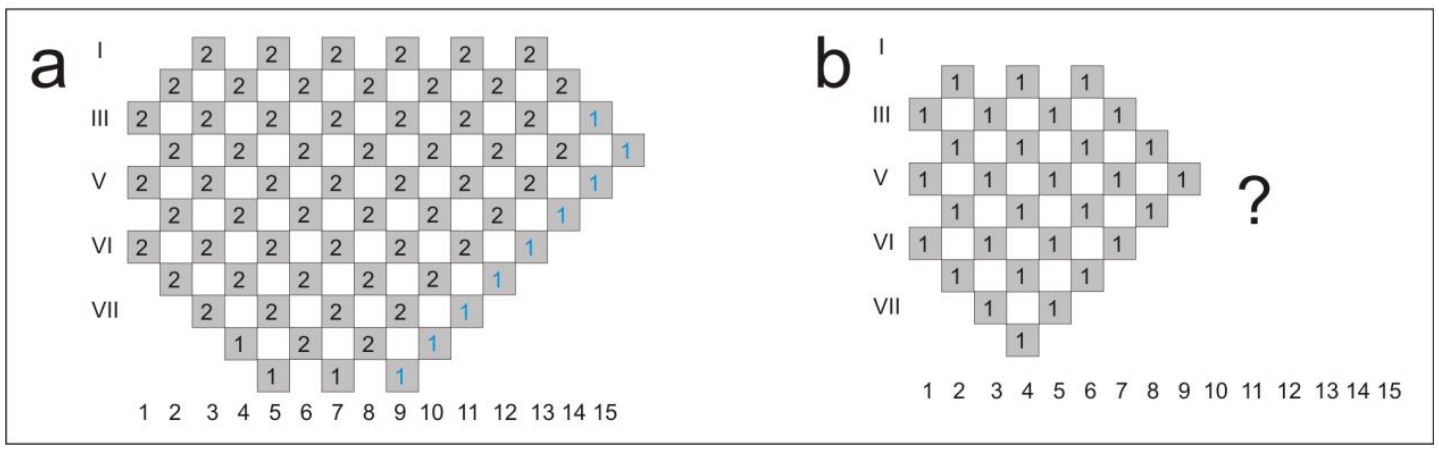


Fig. 5 Phacopid trilobites from the Baruunhuurai Terrane, Olonbulag Subterrane, western Mongolia. (1-3) Feistops khovdensis gen. nov. sp. nov., Hushoot Shiveetiin gol section (bed HS-C-1, Palmatolepis rhomboidea conodont Biozone), Holotype, MUST-RCSP-TRI.-0006, cephalon, respectively, in frontal, dorsal, and lateral views. (4-6) Undetermined phacopids, Hushoot Shiveetiin gol section (bed HS-C-1, Palmatolepis rhomboidea conodont Biozone), MUST-RCSP-TRI.-0013, pygidium, respectively, in frontal, dorsal, and lateral views. (7-9) Undetermined phacopids, Hushoot Shiveetiin gol section (bed HS-C-3, Palmatolepis rhomboidea conodont Biozone), MUST-RCSP-TRI.-0016, exfoliated pygidium, respectively, in frontal, dorsal and lateral views. (10-11) Feistops khovdensis gen. nov. sp. nov., Hushoot Shiveetiin gol section (bed HS-C-1, Palmatolepis rhomboidea conodont Biozone), fragmented cephalothorax, MUST-RCSP-TRI.-0007, respectively, in lateral and dorsal views. (12-13) Undetermined phacopids, Hushoot Shiveetiin gol section (bed HS-C-1, Palmatolepis rhomboidea conodont Biozone), MUST-RCSP-TRI.-0015, mostly exfoliated pygidium, respectively, in dorsal and frontal views. (14) Undetermined phacopids, Hushoot Shiveetiin gol section (bed HS-C-1, Palmatolepis rhomboidea conodont Biozone), MUST-RCSP-TRI.-0014, pygidium in dorsal view. (15-16) ?Feistops sp. A, Hushoot Shiveetiin gol section (bed HS-C-1, Palmatolepis rhomboidea conodont Biozone), MUST-RCSP-TRI.-0008, one fragmented cephalon in dorsal view and one partial left cheek from another cephalon and detail of its left eye. Scale: $3 \mathrm{~mm}$ (except 16: $2 \mathrm{~mm}$ ). Schematic representation of a two visual surfaces in Feistops khovdensis gen. nov. sp. nov., Hushoot Shiveetiin gol section, Holotype (bed HS-C-1); b a partial visual surface in ?Feistops sp. A, Hushoot Shiveetiin gol section (bed HS-C-1). I-VII: horizontal rows; 1-15 (from the front): vertical files. Grey boxes indicate number of lens present.

furrow, and a postocular genal field length equal length of its posterior border. Feistops khovdensis differs from Feistops mongoliensis by its wider cephalon, subdued tubercles on composite lobe, higher divergent axial furrows, a shorter (tr.) occipital ring relative to its total cephalic width (tr.), weaker palpebral furrows, and a subdued palpebral lobe more reniform in dorsal view. The ventral view not accessible prevent us to describe and to compare the anterior cephalic border and the cephalic doublure.

Feistops khovdensis shares with Houseops a relatively subdued transverse cephalic profile, not impressed S2 and S3 glabellar furrows, a relatively flat glabella, weak palpebral furrows, flat palpebral lobes; and especially with Houseops sp. A an ornamentation with fine and dense tubercles on the composite lobe. However, Feistops khovdensis differs from Houseops especially by a genus diagnostic feature, i.e., smaller eyes distant from the posterior margin. Otherwise, Feistops khovdensis differs from ?H. nalivkini by its not inflated abaxially postocular area, a posterolateral border furrow almost effaced, and its more recurved anterolateral corners of the glabella.

\section{?Feistops sp. A}

Fig. 5 (15-16)

Material: One fragmented cephalon plus one left cheek, MUST-RCSP-TRI.-0008 (Fig. 5 (1516)) from Hushoot Shiveetiin gol section, the Baruunhuurai Terrane, Olonbulag Subterrane, western Mongolia; Samnuuruul Formation, Famennian, Palmatolepis rhomboidea conodont Biozone, Late Devonian.

Description: Cephalon: wide, length/width ratio about 0.58. Dorsal view: glabellar ratio of width at L1/maximum width of frontal lobe about 0.44 , narrow at base. Glabella lowered bounded by relatively deep axial furrows that are moderately divergent $\left(65^{\circ}\right)$. Frontal outline 
pointed anteriorly. Frontal lobe hardly overhanging the preglabellar furrow with angular anterolateral corners. S2 and S3 indistinct, maybe indicated by a break in the sculpture. S1 continuous and hardly curved in its middle part, subparallel to S0, and becoming deeper in its distal portions. L1 shorter (sag.) than L0 (more than half-length of L0) and with a wide (tr.) median portion relative to its total width. Median portion of L1 inflated, with tubercles. L1 with subcircular, lightly inflated lateral lobes separated from its median part by a distinct exsagittal furrow. S0 distinct and almost transverse/hardly curved in its middle portion. L0 wide (tr.) with lateral lobes not defined. Reniform visual surface (damaged) apparently lowered, with a maximum of 5 lenses per file. Inter-lensar sclera slightly thickened only dorsally. Palpebral furrow deep and convex (abax.). No subocular pad but a depressed subocular area. Exsagittal length of the postocular genal field almost equal the length (exsag.) of the posterior border. Postocular area strongly inflated even distally with granulation. Cheek swollen. Lateral view: glabella lowered sloping obliquely in its anterior part. Outline of L1 curved. L0 as high as glabella at its maximum convexity. Marginulation no visible. Posterior border furrow very deep and narrow. Lateral border furrow wide and shallow. Posterolateral border furrow shallow and posterolateral border widening at the genal angle. Frontal view: not available. Sculpture: cephalon covered with medium-sized to fine conical tubercles of rather homogeneous size, dense on entire composite lobe.

Comparison: ?Feistops sp. A shares with Feistops mongoliensis: a subdued glabella with a narrow base, axial furrows moderately divergent and similar in depth (deep between S1 and front of palpebral furrow), a wide and inflated median portion (tr.) with tubercles of L1 relative to its total width (tr.), a wide (tr.) of L0 relative to its total width, no S2 and S3, no marginulation, a postero-lateral border furrow distinct and continuous, an almost effaced lateral border furrow, and a postocular genal field length equal length of its posterior border. ?Feistops sp. A differs from Feistops mongoliensis by its wider cephalon, its frontal outline pointed anteriorly, denser tubercles rather homogeneous in size on composite lobe, and a postocular genal field strongly swollen. The ventral view not accessible prevent us to describe and to compare the anterior cephalic border and the cephalic doublure.

These specimens show some morphological features of ?Houseops tamtertensis such as a cephalon with coarse and dense conical tubercles, a lowered glabella pointed anteriorly. However, ?Houseops tamtertensis differs from ?Feistops sp. A by its lowered glabella with a wide base, a visual complex with only 13 dorso-ventral lens files and maximum 3 lenses per file, and a palpebral furrow almost transverse.

?Feistops sp. A resembles ?H. nalivkini on account of the retracted anterior outline of its lowered glabella with subangular anterolateral corners, the inflated abaxially postocular area. However, ?Feistops sp.A differs from ?H. nalivkini by a narrower (tr.) cephalon and its coarser tuberculation.

Genus Houseops Feist et al. 2009 
Type species: Houseops canningensis Feist et al. 2009: Upper Devonian, Canning Basin, Australia.

Species assigned: Houseops canningensis Feist, 2009 in Feist et al. 2009: Famennian (late crepida, i.e., Palmatolepis glabra prima conodont Biozone according to Spalletta et al. 2017), Western Australia; H. beckeri Feist, 2009 in Feist et al. 2009: Famennian (late triangularis, i.e., Palmatolepis minuta minuta conodont Biozone according to Spalletta et al. 2017), Western Australia; H. sp. A Feist, 2009 in Feist et al. (2009): Famennian (late triangularis, i.e., Palmatolepis minuta minuta conodont Biozone according to Spalletta et al. 2017), Western Australia; H. miserrimus miserrimus (Drevermann 1901): Famennian (? late crepida, i.e., Palmatolepis glabra prima conodont Biozone according to Spalletta et al. 2017), Germany; $H$. miserrimus wiedensis (Lütke 1968): Famennian (late crepida, i.e., Palmatolepis glabra prima conodont Biozone according to Spalletta et al. 2017), Germany.

Species tentatively assigned: ?H. pronini Maksimova 1955: Frasnian or basal Famennian?, Urals; ?H. nalivkini (Maksimova 1955): Famennian (possibly triangularis to marginifera), Urals; ?H. ocellatus (Perna 1915), Famennian (possibly triangularis to marginifera), Urals; ?H. tamtertensis (Crônier, 2013 in Crônier et al. 2013), Famennian (possibly triangularis to marginifera), Algeria; ?H. olonbulagensis sp. nov.: Famennian, western Mongolia.

?Houseops olonbulagensis sp. nov.

Fig. 6 (1-9)

Etymology: After the Olonbulag Subterrane of western Mongolia.

Holotype: Cephalothorax MUST-RCSP-TRI.-0009 (Fig. 6 (7-8)).

Paratypes: Two fragmented exoskeletons MUST-RCSP-TRI.-00010-11(Fig. 6 (1-6)).

Type locality: Hushoot Shiveetiin gol section, the Baruunhuurai Terrane, Olonbulag Subterrane, western Mongolia.

Type stratum: Samnuuruul Formation, Famennian (greenish shale), Palmatolepis glabra pectinata conodont Biozone, Late Devonian.

Material: Holotype MUST-RCSP-TRI.-0009, one fragmented enrolled exoskeleton MUSTRCSP-TRI.-0010 and one fragmented unrolled exoskeleton MUST-RCSP-TRI.-0011 from HSF10 (Palmatolepis glabra pectinata conodont Biozone); one thoracopygon associated to one pygidium MUST-RCSP-TRI.-0012 from HS-C-5 (Palmatolepis glabra pectinata conodont Biozone).

Diagnosis: Cephalon wide; glabella bounded by low divergent axial furrows; L1 with subquadrate lateral lobes, not strongly inflated; visual complex with at least 13 dorsoventral files of lenses and a maximum of 5 lenses per file; thin inter-lensar sclera; palpebral furrow weak and 
convex (abax.); exsagittal length of the postocular genal field almost equal length (exsag.) of the posterior border. Moderately dense medium-sized tubercles on glabella.

Description: Cephalon: wide, length/width ratio about 0.57 . Dorsal view: glabellar ratio of width at L1/maximum width of frontal lobe about 0.49 , narrow at base. Glabella lowered bounded by relatively deep axial furrows that are low divergent $\left(55^{\circ}\right)$. Frontal outline parabolic anteriorly. Frontal lobe hardly overhanging a deep preglabellar furrow. S2 and S3 indistinct on the internal mold. S1 damaged in its middle part, deep in its distal portions. L1 shorter (sag.) than L0 (more than half-length of L0) and with a wide (tr.) median portion relative to its total width. Median portion of L1 inflated, without tubercles presumably. L1 with subquadrate lateral lobes, not strongly inflated, separated from its median part by a weak exsagittal furrow. S0 distinct and almost transverse/hardly curved in its middle portion. L0 rather wide (tr.) with lateral lobes not defined. Reniform visual surface with at least 13 dorso-ventral files of lenses and a maximum of 5 lenses per file. Inter-lensar sclera thin presumably. Palpebral furrow weak and convex (abax.). Exsagittal length of the postocular genal field almost equal length (exsag.) of the posterior border. Lateral view: glabella sloping obliquely dorsoventrally in its anterior part. Outline of L1 rather strongly curved. L0 as high as glabella at its maximum convexity. Anterior border relatively short, forming a border projected forward and sloping posteroventrally. Marginulation apparently present on the posterolateral border. Posterior border furrow deep and narrow. Lateral border furrow no visible (damaged) at the front of the eye, shallow backwards. Subocular librigenal field no visible (damaged) at the front of the eye, becoming larger and concave backwards with no subocular pad. Posterolateral border furrow shallow and continuous and posterolateral border widening at the genal angle. Frontal view: glabellar outline semicircular becoming oblique laterally (divergence of $50^{\circ}$ ). Palpebral area inflated and as high as palpebral lobe. Ventral view: vincular furrow relatively deep and wide (sag.), broadly and evenly curved. Posterior band of the cephalic doublure long (sag.), with a hypostomal suture apparently transverse medially. Thorax: slightly tapered with apparently 10 thoracic axial rings (untypically). Maximum axial width (tr.) ratio of the last ring/first ring about $86 \%$. Axial rings convex without defined lateral lobes. Axial furrows distinct. Anterior pleural band narrower (exsag.) than the posterior pleural band. Pleural furrows narrow and distinct. Pygidium: mostly exfoliated. Wide with a length/width ratio about $38 \%$ (excluding the half ring), and its maximum width (tr.) in front of its midlength (sag.) in dorsal view. Posterior outline roughly broadly rounded. Pydigial axis long (sag.) and rather narrow (tr.), tapered, with rather complete terminal closure. Pygidial axis showing a slight constriction from the fourth axial ring. Seven distinct rings in the pygidial axis. Pygidial pleural field with five distinct ribs delimited by deep pleural furrows. Interpleural furrows indistinct. Pseudoarticulating half rings very weakly suggested by expanded inter-rings furrows. Sculpture: internal mold of glabella covered with medium-sized tubercles of rather homogeneous size, moderately dense on entire composite lobe, and pits. Posterolateral border with pits. Cheek, postocular area, posterior border, lateral preoccipital lobe, posterior band of the cephalic doublure, thorax and pygidium showing no evidence of sculpture. 
Comparison: The holotype is partially exfoliated and fragmented that prevent us to get a complete description. We are not confident with this assignation but ?Houseops olonbulagensis and Houseops (Fig. 6b) seem to share similar sagittal sections. However, it is not impossible with more material that the few studied specimens may belong to a new genus. Nevertheless, the two associated fragmented exoskeletons allow to approach an almost complete description. ?Houseops olonbulagensis sp. nov. differs from Feistops mongoliensis gen. nov. sp. nov. in having a wide cephalic outline, coarser pustular and dense tubercles only on the composite lobe, and a pygidial axis less long and more tapered.

?Houseops olonbulagensis sp. nov. shares with from ?Houseops nalivkini (Maksimova 1955) from the early Famennian of the Southern Urals a wide cephalon and apparently an inflated genal field but differs by its shallow posterolateral border furrow, its less swollen postero-lateral border, and its coarser tuberculation.

?Houseops olonbulagensis sp. nov. shares with Omegops mobilis (Xiang 1981) or $O$. ?cornelius (Richter and Richter 1933) from the late Famennian of the Northwest China coarse tubercles on glabella and a marginulate lateral border. However, Omegops mobilis or $O$. ?cornelius differ from ?Houseops olonbulagensis sp. nov. by their reduced intercalating ring as a narrow flat band and their distinct postocular pad.

Undetermined phacopids.

Fig. $5(4-6,7-9,12-13,14)$

Material: Two isolated pygidia MUST-RCSP-TRI.-0013-14 from HS-C-1 (Fig. 5 (4-6, 14)) and one mostly exfoliated pygidium MUST-RCSP-TRI.-0015 from HS-C-1_crino layer (Fig. 5 (1213)): Hushoot Shiveetiin gol section, the Baruunhuurai Terrane, Olonbulag Subterrane, western Mongolia; Samnuuruul Formation, Famennian, Palmatolepis rhomboidea conodont Biozone, Late Devonian. These pygidia can be assigned to Feistops khovdensis gen. nov. sp. nov. or ?Feistops sp. A but no complete exoskeleton prevents a specific assignation. An additional exfoliated pygidium MUST-RCSP-TRI.-0016 from HS-C-3 (Fig. 5 (7-9)) and a pygidium counterpart from HS-F7 can be assigned to these taxa.

Description: Pygidium: rather wide with a length/width ratio about $49 \%$ (excluding the half ring), and its maximum width (tr.) at about its midlength (sag.) in dorsal view. Posterior outline roughly broadly rounded to roughly transverse medially. Pydigial axis long (sag.) and rather narrow (tr.), tapered, with rather incomplete terminal closure. Pygidial axis showing a slight constriction from the fourth axial ring (Fig. 4 (5)). At least seven distinct rings in the pygidial axis. Pygidial pleural field with 5-6 distinct ribs delimited by deep pleural furrows. Interpleural furrows indistinct. Pseudo-articulating half rings very weakly suggested by expanded inter-ring furrows. Sculpture: pygidium showing no evidence of sculpture. 

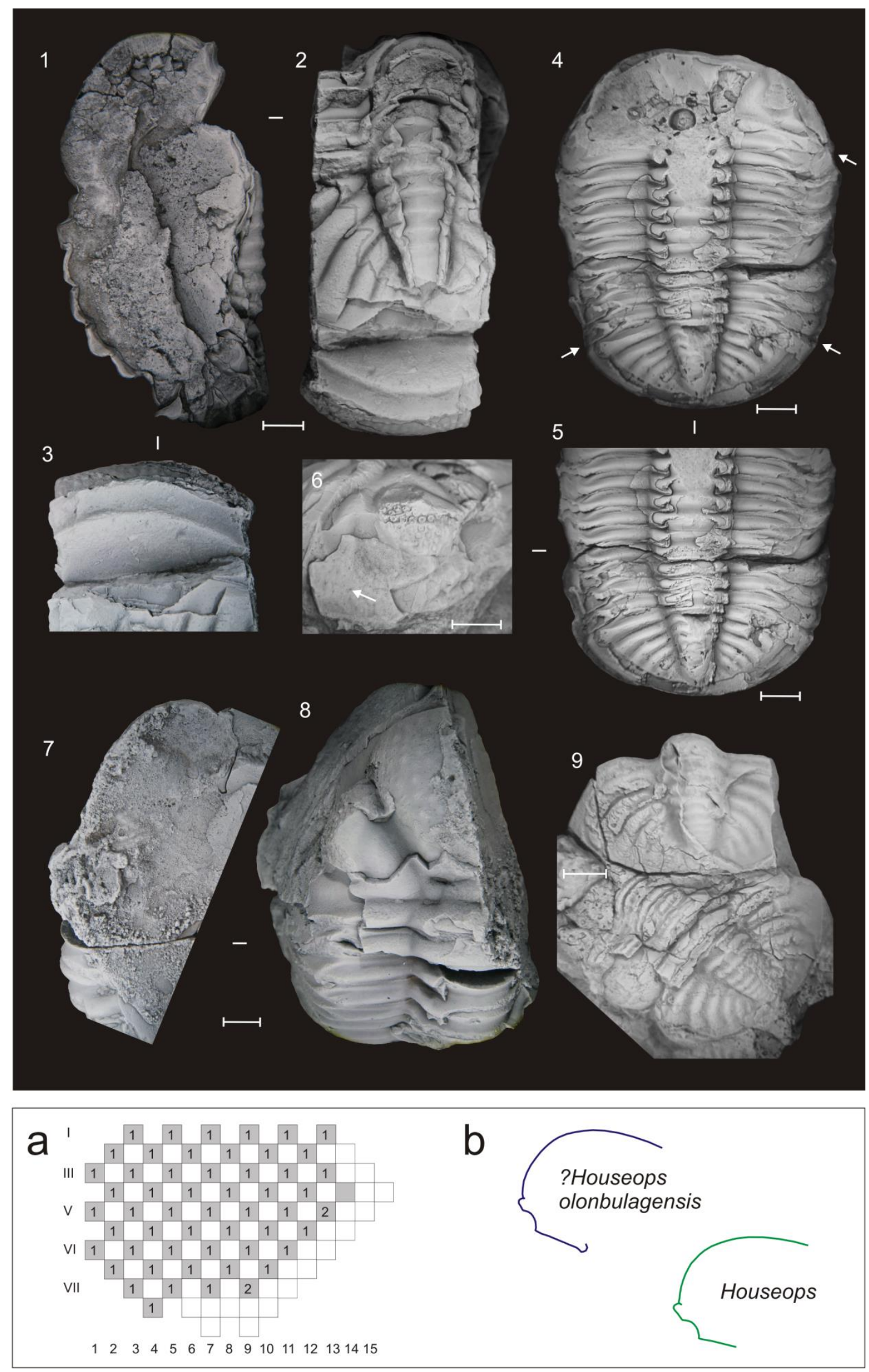
Fig. 6 Phacopid trilobites from the Baruunhuurai Terrane, Olonbulag Subterrane, western Mongolia. (13)?Houseops olonbulagensis sp. nov., Hushoot Shiveetiin gol section (bed HS-F10, Palmatolepis glabra pectinata conodont Biozone), fragmented enrolled exoskeleton, MUST-RCSP-TRI.-0010, respectively, in lateral and ventral views, and detail of the vincular furrow. (4-6)?Houseops olonbulagensis sp. nov., Hushoot Shiveetiin gol section (bed HS-F10, Palmatolepis glabra pectinata conodont Biozone), fragmented unrolled exoskeleton, MUST-RCSPTRI.-0011, respectively, in dorsal views and detail of the right eye. (7-8)?Houseops olonbulagensis sp. nov., Hushoot Shiveetiin gol section (bed HS-F10, Palmatolepis glabra pectinata conodont Biozone), Holotype, MUSTRCSP-TRI.-0009, fragmented cephalothorax, respectively, in lateral and dorsal views. (9)?Houseops olonbulagensis sp. nov., Hushoot Shiveetiin gol section (bed HS-C-5, Palmatolepis glabra pectinata conodont Biozone), one thoracopygon associated to one pygidium in dorsal view, MUST-RCSP-TRI.-0012. Scale: $3 \mathrm{~mm}$ (except 6: $2 \mathrm{~mm}$ ). Schematic representation of a a visual surface in ?Houseops olonbulagensis sp. nov., Hushoot Shiveetiin gol section, Holotype (bed HS-F10); b sagittal profiles of anterior part of cephalon in ?Houseops olonbulagensis sp. nov. (Holotype), and Houseops illustrated in Feist 2019. I-VII: horizontal rows; 1-15 (from the front): vertical files. Grey boxes indicate number of lens present.

\section{Discussion and conclusions}

The studied material comes from the eastern part of the Hushoot Shiveetiin gol section that ranges stratigraphically from the Palmatolepis minuta minuta conodont Biozone to at least the Palmatolepis rugosa trachytera conodont Biozone with hiatuses of several conodont biozones (Munkhjargal et al. 2021). Trilobites were sampled in six levels (levels HS-C1, C3/F7, C5, F10, C13, and F15) which also yielded other fauna such as diverse conodonts and macrofossils including brachiopods, solitary rugose corals, branching tabulate corals (Suttner et al. 2020; Munkhjargal et al. 2021, Nazik et al. 2021, Waters et al. 2021).

The studied material is most often incomplete, difficult to prepare, and often preserved as internal mold. Due to insufficient preservation of the cephala, additional material is required. However, the relatively well-preserved phacopid trilobites are assigned to Feistops mongoliensis gen. nov. sp. nov. and ?Houseops olonbulagensis sp. nov. from the crepida conodont Biozone, Feistops khovdensis gen. nov. sp. nov. and ?Feistops sp. A from the Palmatolepis rhomboidea conodont Biozone, thus becoming four endemic taxa from western Mongolia because of their cephalic shape and doublure when visible. Moreover, according to conodont biofacies and microfacies analyses (Suttner et al. 2020; Munkhjargal et al. 2021), a slight change in bathymetric conditions seems to occur from a slight shallowing during the late Palmatolepis crepida conodont Biozone followed by a deepening during the Palmatolepis rhomboidea conodont Biozone in the Hushoot Shiveetiin gol section.

Interestingly, in order to get a better understanding on the distribution of Late Devonian faunas at the interface of palaeogeography and palaeoecology, a comparison of our trilobite fauna with those from the western Junggar of Xinjiang, Northwest China, from the Hongguleleng Formation (stratotype) will be useful. This as a reference section in comparison to other sections in the CAOB including the studied western Mongolia Hushoot Shiveetiin gol section. Indeed, the Hongguleleng Formation is also Famennian in age, with evidence for the Frasnian/Famennian boundary near the base of the Stratotype section and the Hangenberg Event near the top. This formation is characterized by a very well-preserved and diverse marine faunal assemblage with abundant brachiopods, numerous crinoids and blastoids, and phacopid trilobites (Waters et al. 
2003; Suttner et al. 2014; Zong and Gong 2017). Phacopids occur from the late rhomboidea Biozone, i.e., the Palmatolepis gracilis gracilis Biozone (Spalletta et al. 2017), to the D/C boundary, but they are most abundant in the late rhomboidea conodont Biozone, i.e., the Palmatolepis gracilis gracilis Biozone (Spalletta et al. 2017; Suttner et al. 2014). This interval consists of deeper water facies with maroon and green shales and cherts. Unfortunately, no phacopid specimens have been illustrated or described. Moreover, some trilobites (not yet studied but with an equivalent age to the Mongolian phacopids) have been found with a mixed fauna of very small crinoids, brachiopods, corals and bryozoans in the lower part of the section from an interval of very thin-bedded limestone with shale, and volcaniclastic rocks within the crepida Biozone (personal communication JW).

At a global scale, excluding the Americas, Famennian phacopids are characterized by a worldwide distribution (Chlupáč 1975; Crônier and François 2014). However, if the majority of genera is apparently limited to a single cratonic margin, the other few genera are cosmopolitan (Crônier and François 2014). New discoveries in unexploited areas such as the newly studied western Mongolia once again reveals the endemic nature of many genera.

In the early Famennian, the post-Kellwasser event recovery marked a new step, especially for phacopid trilobites (Lerosey-Aubril and Feist 2012; Crônier et al. 2013). The evolutionary pattern in phacopids shows a major increase in the specific origination during the late early Famennian (Crônier et al. 2013). A first turnover occurred during the lower Famennian with few new genera reported, i.e., Nephranops Richter and Richter 1926 in European deep offshore cephalopod environments and Pulvinocephalus Feist 2019 from the Palmatolepis triangularis Biozone. Nevertheless, the significant post-Kellwasser recovery occurred during the late early Famennian leading to a second turnover with new blind phacopid genera from deep offshore habitats and eyed phacopid genera from shallower habitats in the photic zone (Crônier et al. 2013; Feist 2019). This study provides an update for species and subspecies currently known with regard to their age distribution according to conodont zonation.

\section{Acknowledgements}

This is a contribution to a special series on "The Cental Asian Orogenic Belt (CAOB) during Late Devonian: new insights from southern Mongolia." IGCP 596 and its successor, the Western MongolianWorking Group, have conducted fieldwork inMongolia with the goal of identifying Late Devonian extinction and anoxia events that were previously recognized in coeval CAOB terranes in western China. This paper is a contribution to IGCP Project 652 (Reading geologic time in Paleozoic rocks: the need for an integrated stratigraphy [2017-2021]). We acknowledge Sersmaa Gonchigdorj for collecting and bringing samples to Europe. We thank Allart van Viersen (Belgium) and Raimund Feist (France) as reviewers for their comments and suggestions.

\section{Funding}


The study is financially supported by the German Academic Exchange Service (DAAD, research grant-Doctoral Programme in Germany, September 01, 2018-September 01, 2021; 57381412), the German Science Foundation (DFG, Ko 1622-19/1), National Geographic (CP-113R-17), and Appalachian State University. The authors (CC) thank the Région Hauts-de-France, and the Ministère de l'Enseignement Supérieur et de la Recherche (CPER Climibio) for their financial support.

\section{Compliance with ethical standards}

Conflict of interest: The authors declare that they have no conflict of interest.

\section{References}

Algeo, T.J., \& Scheckler, S.E. (1998). Terrestrial-marine teleconnections in the Devonian: links between the evolution of land plants, weathering processes, and marine anoxic events. Philosophical Transactions of The Royal Society, B Biological Sciences, 353(1365), 113-130. https://doi.org/10.1098/rstb.1998.0195.

Ariunchimeg, Ya., Bayasgalan, A., Waters, J.A., Kido, E., Suttner, T.J., Sersmaa, G., Undariya, J., \& Otgonbaatar, D. (2014). IGCP 596 IGCP580 Field Workshop Guidebook. 8-18th August, 2014, Ulaanbaatar, Mongolia. Paleontological Center, Mongolian Academy of Sciences, 1-55.

Badarch, G., Byamba, J., Mahbadar, Ts, Minjin, Ch., Orolmaa, D., Tumurtogoo, O., \& Khosbayar, Ts. (1998). Summary. In: Tumurtogoo, O., Byamba, J., Badarch, G., Minjin, Ch., Orolmaa, D., Khosbayar, Ts., Chuluun, D., Makhbadar, Ts., \& Bat-Ireedui, Y. (1998). Geological map of Mongolia, scale 1:1,000,000: Mineral Resources Authority of Mongolia. Geological Survey and Mongolian Academy of Sciences, Institute of Geology and Mineral Resources, Ulaanbaatar, 1-30 [In Mongolian].

Becker, R.T., Königshof, P., \& Brett, C.E. (2016). Devonian climate, seal level and evolutionary events: An introduction. Geological Society of London, Special Publication, 432, 1-10. https://doi.org/10.1144/SP423.15.

Blakey, R. (2016). Devonian-380 Ma, global paleogeography and tectonics in deep time series. Deep time maps ${ }^{\mathrm{TM}}$ paleogeography.

Bolshakova, L.N., Bondarenko, O.B., Minjin, C., Ulitina, L.M., \& Sharkova, T.T. (2003). Paleontology of Mongolia: corals and stromatoporoids (pp. 199-256). Moskow: Nauka [In Russian].

Bond, D.P.G., \& Grasby, S.E. (2017). On the causes of mass extinctions. Palaeogeography Palaeoclimatology Palaeoecology, 478, 3-29. https://doi.org/10.1016/j.palaeo.2016.11.005.

Chlupáć, I. (1975). The distribution of phacopid trilobites in space and time. Fossils and Strata, 4, 399-408. 
Chlupáč, I. (1977). The phacopid trilobites of the Silurian and Devonian of Czechoslovakia. Rozpravy ústředního ústavu geologického, 43, 1-172.

Crônier, C. (2010). Varied development of trunk segmentation in three related Upper Devonian phacopine trilobites. Historical Biology, 22, 341-347.

Crônier, C., \& Clarkson, E.N.K. (2001). Variation of eyes-lens distribution in a new late Devonian phacopid trilobite. Transactions of the Royal Society of Edinburgh: Earth Sciences, 92, 103-113.

Crônier, C., \& François, A. (2014). Distribution patterns of Upper Devonian phacopid trilobites: paleobiogeographical and paleoenvironmental significance. Palaeogeography, Palaeoclimatology, Palaeoecology, 404, 12-23.

Crônier, C., Bignon, A., \& François, A. (2011). Morphological and ontogenetic criteria for defining a trilobite species: the example of Siluro-Devonian Phacopidae. Comptes Rendus Palevol, 10, 143-153.

Crônier, C. (2013). Systematic palaeontolgy. In C. Crônier, F.Z. Malti, A. François, M. Benyoucef, \& D. Brice, (Eds.), First occurrence of a phacopid trilobite faunule from the Upper Devonian of Saoura Valley, Algeria and biodiversity fluctuations. Geological Magazine, 150, 1004-1013.

Crônier, C., Malti, F.Z., François, A., Benyoucef, M., \& Brice, D. (2013). First occurrence of a phacopid trilobite faunule from the Upper Devonian of Saoura Valley, Algeria and biodiversity fluctuations. Geological Magazine, 150, 1002-1021.

Dergunov, A.B. (2001). Tectonics, magmatism, and metallogeny of Mongolia (pp. 288). LondonNew York: Routledge.

Drevermann, F. (1901). Die Fauna der oberdevonischen Tuffbreccie von Langenaubach bei Haiger. Jahrbuch der Preußischen Geologischen, Landesanstalt, 1900, 99-207.

Ernst, A. (2013). Diversity dynamics and evolutionary patterns of Devonian Bryozoa. Palaeobiodiversity and Palaeoenvironments, 93, 45-63. https://doi.org/10.1007/s12549-0120086-4.

Feist, R. (2009). Systematic palaeontology. In R. Feist, K.J. McNamara, C. Crônier, \& R. Lerosey-Aubril, (Eds.), Patterns of extinction and recovery of phacopid trilobites during the Frasnian-Famennian (Late Devonian) mass extinction event, Canning Basin, Western Australia. Geological Magazine, 146(1), 14-28. https://doi.org/10.1017/S0016756808005335.

Feist, R. (2019). Post-Kellwasser event recovery and diversification of phacopid trilobites in the early Famennian (Late Devonian). Bulletin of Geosciences, 94, 1-22. 
Feist, R., \& Becker, T. (1997). Discovery of Famennian trilobites in Australia (Late Devonian, Canning Basing, NW Australia). Geobios (Mémoire special), 20, 231-242.

Feist, R., McNamara, K.J., Crônier, C., \& Lerosey-Aubril, R. (2009). Patterns of extinction and recovery of phacopid trilobites during the Frasnian-Famennian (Late Devonian) mass extinction event, Canning Basin, Western Australia. Geological Magazine, 146, 12-33.

Hara, H., Kurihara, T., Kuroda, J., Adachi, Y., Kurita, H., Wakita, K., Hisada, K., Charusiri, P., Charoentitirat, T., \& Chaodumrong, P. (2010). Geological and geochemical aspects of a Devonian siliceous succession in northern Thailand: implications for the opening of the PaleoTethys. Palaeogeography, Palaeoclimatology, Palaeoecology, 297, 452-464.

Hartenfels, S. (2011). Die globalen Annulata-Events und die Dasberg-Krise (Famennium, Overdevon) in Europa und Nord-Afrika-hochauflösende Conodonten-Stratigraphie, KarbonatMikrofazies, Paläoökologie und Paläodiversität. Münsterische Forschung zur Geologie und Paläontologie, 105, 17-527.

Hawle, I., \& Corda, A.J.C. (1847). Prodom einer Monographie der böhmischen Trilobiten. Abhandlungen der Königlichen Böhemischen Gesellschaft der Wissenschaften, 5, 1-176.

Kido, E., Suttner, T.J., Waters, J.A., Ariunchimeg, Ya., Sersmaa, G., Atwood, J.W., \& Webster, G.D. (2013). Devonian deposits of the Baruunkhuurai Terrane, western Mongolia (IGCP 596 Field Workshop). Episodes, 36, 242-254. https://doi.org/10.18814/epiiugs/2013/v36i4/001.

Lerosey-Aubril, R., \& Feist, R. (2012). Earth and Life: Global Biodiversity, Extinction Intervals and Biogeographic Perturbations through Time. In J.A. Talent (Ed.), Quantitative approach of diversity and decline in late Palaeozoic trilobites (pp. 535-555). Springer Publishing.

Li, P., Sun, M., Rosenbaum, G., Jourdan, F., Li, S., \& Cai, K. (2017). Late Paleozoic closure of the Ob-Zaisan Ocean along the Irtysh Shear zone (NW China): implications for arc amalgamation and oroclinal bending in the Central Asian Orogenic Belt. Geological Society of American Bulletin, 129, 547-569. https://doi.org/10.1130/B31541.31541.

Lütke, F. (1968). Trilobiten aus dem Oberdevon des Südwest-Harzes, Stratigraphie, Biotop und Systematik. Senckenbergiana Lethaea, 49, 119-191.

Maksimova, Z.A. (1955). Trilobity srednego $i$ verchnego devona Urala isevernych Mugodzar. Internal report. Vsesoyuznogo Nauchno-Issledovatelskii Geologicheskii Institut Trudy, n. S. 3, 1-263 [In Russian].

Metcalfe, I. (2011). Tectonic framework and Phanerozoic evolution of Sundaland. Gondwana Research, 19, 3-21.

Munkhjargal, A., Königshof, P., Hartenfels, S., Jansen, U., Nazik, A., Carmichael, S.K., Waters, J.A., Sersmaa, G., Crônier, C., Ariunchimeg, Ya., Paschall, O., \& Dombrowski, A. (2021). The 
Hushoot Shiveetiin gol section (Baruunhuurai Terrane): Sedimentology and facies from a Late Devonian island arc setting. Palaeobiodiversity and Palaeoenvironments, 101(3). https://doi.org/10.1007/s12549-020-00445-0.

Münster, G.G. (1840). Die Versteinerungen des Uebergangskalkes mit Clymenien und Orthoceratiten von Oberfranken. Beiträge zur Petrefakten-Kunde III Heft, 7, 33-121.

Nazik, A., Königshof, P., Ariuntogos, M., Waters, J.A., \& Carmichael, S.K. (2021). Ostracod assemblage of the Late Devonian Hushoot Shiveetiin gol island arc section (Baruunhuurai Terrane, western Mongolia). Palaeobiodiversity and Palaeoenvironments, 101(3). https://doi.org/10.1007/s12549-020-00446-z.

Perna, A. (1915). Upper Devonian trilobites from the environs of the town Vierkhnie-Uralsk. Mémoires du Comité Géologique, Nouvelle Série, Petrograd, 138, 1-56.

Racki, G. (2005). Toward understanding Late Devonian global events: few answers, many questions. In D.J. Over, J.R. Morrow, \& P.B.Wignall, (Eds.), Understanding Late Devonian and Permian-Triassic Biotic and Climatic Events. Towards an Integrated Approach, 20, 5-36. https://doi.org/10.1016/S0920-5446(05)80002-0.

Richter, R., \& Richter, E. (1926). Die Trilobiten des Oberdevons. Beiträge zur Kenntnis devonischer Trilobiten IV. Abhandlungen der Preußischen Geologischen, Landesanstalt, Neue Folge, 99, 1-314.

Richter, R., \& Richter, E. (1931). Unterlagen zum Fossilium Catalogus, Trilobitae. V. Senckenbergiana, 13, 140-146.

Richter, R., \& Richter, E. (1933). Die letzten Phacopidae. Bulletin du Musée Royal d'Histoire Naturelle de Belgique, 9, 1-19.

Safonova, I., Kotlyarov, A., Krivonogov, S., \& Xiao, W. (2017). Intraoceanic arcs of the PaleoAsian Ocean. Elsevier, Gondwana Research, 50, 167-194. https://doi.org/10.1016/j.gr.2017.04.005.

Salter, I.W. (1864). A monograph of the British trilobites. Palaeontographical Society London, $16,1-80$.

Sepkoski, J.J. (1996). Patterns of Phanerozoic extinction: a perspective from global databases. In O.H. Walliser (Ed.), Global events and event stratigraphy in the Phanerozoic (pp. 35-51). Berlin: Springer-Verlag. https://doi.org/10.1007/978-3-642-79634-0_4.

Spalletta, C., Perri, M.C., Over, D. J., \& Corradini, C. (2017). Famennian (Upper Devonian) conodont zonation: revised global standard. Bulletin of Geosciences, 92, 31-57. 
Stein, W.E., Mannolini, F., Hernick, L., Landing, E., \& Berry, C.M. (2007). Giant cladoxylopsid trees resolve the enigma of the Earth's earliest forest stumps at Gilboa. Nature, 446, 904-907. https://doi.org/10.1038/nature05705.

Struve, W. (1976). Beiträge zur Kenntnis der Phacopina (Trilobita), 9: Phacops (Omegops) n. sg. (Trilobita; Ober-Devon). Senckenbergiana Lethaea, 56, 429-451.

Suttner, T.J., Kido, E., Chen, X.Q., Mawson, R., Waters, J.A., Fryda, J., Mathieson, D., Molloy, P.D., Pickett, J., Webster, G.D., \& Frydova, B. (2014). Stratigraphy and facies development of the marine Late Devonian near the Boulongour Reservoir, northwest Xinjiang, China. Journal Asian Earth Sciences, 80, 101-118. https://doi.org/10.1016/j.jseaes.2013.11.001.

Suttner, T.J., Kido, E., Ariunchimeg, Ya., Sersmaa, G., Waters, J.A., Carmichael, S.K., Batchelor, C. J., Ariuntogos, M., Huškova, A., Slavík, L., Valenzuela-Ríos, J. L., Liao, J.-C., \& Gatovsky, Y. A. (2020). Conodonts from Late Devonian island arc settings (Baruunhuurai Terrane, western Mongolia). Palaeoclimatology, Palaeoecology, Palaeogeography, 549, 1-22. https://doi.org/10.1016/j.palaeo.2019.03.001.

Van Viersen, A.P., \& Vanherle, W. (2018). The rise and fall of Late Devonian (Frasnian) trilobites from Belgium: taxonomy, biostratigraphy and events. Geologica Belgica, 21, 73-94. https://doi.org/10.20341/gb.2018.005.

Waters, J.A., \& Webster, G.D. (2009). A re-evaluation of Famennian echinoderm diversity: Implications for patterns of extinction and rebound in the Late Devonian. In P. Königshof (Ed.), Devonian change: case studies in palaeogeography and palaeoecology, The Geological Society, London, Special Publication, 314, 149-161.

Waters, J.A., Maples, C.G., Lane, N.G., Marcus, S., Liao, Z., Liu, L., Hou, H., \& Wang, J. (2003). A quadrupling of Famennian pelmatozoan diversity: new Late Devonian blastoids and crinoids from northwest China. Journal of Paleontology, 77, 922-948. https://doi.org/10.1017/S0022336000044772.

Waters, J.A., Waters, J.W., Königshof, P., Carmichael, S.K., \& Ariuntogos, M. (2021). Famennian Crinoids and Blastoids (Echinodermata) from Mongolia. Palaeobiodiversity and Palaeoenvironments, 101(3). https://doi.org/10.1007/s12549-020-00450-3.

Xiang, L.-W. (1981). Some Late Devonian trilobites of China. Geological Society of America, 187, 183-187.

Xiao, W., \& Santosh, M. (2014). The western entral Asian Orogenic Belt: a window to accretionary orogenesis and continental growth. Gondwana Research, 25, 1429-1444. https://doi.org/10.1016/j.gr.2014.01.008. 
Xiao, W.J., Huang, B.C., Han, C.M., Sun, S., \& Li, J.L. (2010). A review of the western part of the Altaids: a key to understanding the architecture of accretionary orogens. Gondwana Research, 18, 253-273. https://doi.org/10.1016/j.gr.2010.01.007.

Yang, G., Li, Y., Tong, L., Wang, Z., Duan, F., Xu, Q., \& Li, H. (2019). An overview of oceanic island basalts in accretionary complexes and seamounts accretion in the western Central Asian Orogenic Belt. Journal of Asian Earth Sciences, 179, 385-398. https://doi.org/10.1016/j.jseaes.2019.04.011.

Yuan, J., \& Xiang, L. (1998). Trilobite fauna at the Devonian-Carboniferous boundary in South China (S-Guizhou and N-Guangxi). Natural Museum of Natural Science, Special Publication, 8, $1-281$.

Zong, R.W., \& Gong, Y. (2017). Behavioural asymmetry in Devonian trilobites. Palaeogeography, Palaeoclimatology, Palaeoecology, 476, 158-162. 
Chapter 4 - The Mandalovoo-Gurvansayhan terranes in the southern Gobi of Mongolia: new insingts from the Bayankhoshuu Ruins section

Munkhjargal, A. ${ }^{1,2}$, Königshof, P. ${ }^{2}$, Waters, J.A. ${ }^{3}$, Carmichael, S.K. ${ }^{3}$, Sersmaa, G. ${ }^{1}$, Thassanapak, H. ${ }^{4}$, Udchachon, M. ${ }^{4}$ \& Davaanyam, Sh. ${ }^{5}$

(1) Mongolian University of Science and Technology, Baga toiruu, Sukhbaatar District, Ulaanbaatar, Mongolia

(2) Senckenberg Research Institute and Natural History Museum, Senckenberganlage 25, 60325 Frankfurt, Germany; http://orcid.org/0000-0001-5300-8469

(3) Department of Geological and Environmental Sciences, Appalachian State University, 572 Rivers St., Boone, NC 28608, USA

(4) Paleontological Research and Education Center, Mahasarakham University, Mahasarakham 44150, Thailand

(5) Institute of Geology, Mongolian Academy of Science, Labor union Street, Songinokhairkhan district, Ulaanbaatar 18080, Mongolia

Published in Palaeobiodiversity and Palaeoenvironments 17 February 2021, Received: 26 August 2020/Accepted: 21 July 2020, https://doi.org/10.1007/s12549-020-00471-y.

\begin{abstract}
The Bayankhoshuu Ruins section in southern Mongolia is characterized by strongly thrusted and folded sequences. Overall, three sections ranging from Ordovician to Carboniferous rocks were studied. Facies analysis combined with stratigraphic data provide improved lithostratigraphic descriptions of Palaeozoic successions in the Mushgai region. The overall marine sedimentary sequence is punctuated by volcanic rocks-basaltic lava of Silurian and Middle Devonian age and volcaniclastic bentonite and tuff in the Middle to Late Devonian and Mississippian suggesting an island arc setting. The Minjin Member of the Botuulkhudag Formation (Middle Devonian to Late Devonian) is primarily composed of thick basaltic and subaerial volcanic rocks with minor silicified siltstone and chert inclusions. Thicker successions of limestone occur in the Ordovician/Silurian, Early Devonian, and the Mississippian. The macrofauna is scarce, except distinct limestone horizons where different fossil groups were recognized. Microfossils, such as radiolarians and conodonts, are scarce and generally poorly preserved. However, based on the restudy of collections from earlier publications and new conodont data, a more detailed biostratigraphic record of the Khoyormod, Botuulkhudag, and Arynshand formations of the Bayankhoshuu Ruins section can be developed. For instance, the Arynshand Formation likely ranges from the late Bispathodus ultimus conodont biozone to the Scaliognathus anchoralisDoliognathus latus conodont biozone. A tectonic breccia occurs in the early Mississippian and is overlain by a red shale of remarkable thickness at the top of this formation which points to subaerial exposure in the early Mississippian (near the Tournaisian/Visean transition). Due to strong tectonic overprint and/or facies, some unconformities/hiatuses occur. Most strata are
\end{abstract}


intensively folded and faulted, ranging from centimeter to meter scale. Overall, deposition likely occurred on either the Mandalovoo or Gurvansayhan Terrane.

Keywords: Central Asian Orogenic Belt (CAOB), Mongolia, Palaeozoic biostratigraphy, Volcanism, Hemipelagic/pelagic facies, Island arc.

\section{Introduction and geological frame}

The Central Asian Orogenic Belt (CAOB) is the world's largest Palaeozoic accretionary orogenic belt. The CAOB covers a huge area which extends from Kazakhstan in the west, through Kyrgyzstan, Uzbekistan, northwestern China, the Altai-Sayan region and Transbaikalia in Russia, Mongolia, and northeastern China to the Russian Far East. The accretionary system includes oceanic, intra-oceanic, and numerous fragments of Precambrian microcontinents and collisional and post-collisional complexes as well as continental margin arc terranes. In the last two decades, significant progress has been made in understanding the complex plate tectonic dynamics by studies on geochronological, geochemical, and isotope dating preferably from magmatic and metamorphic rocks (Badarch et al. 2002; Windley et al. 2007; Xiao et al. 2010; Kröner et al. 2014; Xiao and Santosh 2014; Safonova et al. 2017; Yang et al. 2019, among others). Papers outlining the terranes and tectonic history of Mongolia do not necessarily have broad generalizations about the geology of specific areas. Although several petrological, geochemical, and structural studies were conducted to get a better understanding on the complex framework of the $\mathrm{CAOB}$, detailed sedimentological and stratigraphical descriptions are scarce. The primary references for the geology of the studied area (Bayankhoshuu Ruins; Umnugobi Province, southern Mongolia) is published in the guidebook for the 2001 joint meeting of IGCP 410 and 421 (Minjin et al. 2001) and in later publications by Wang et al. (2003a, b, 2005).

The Bayankhoshuu Ruins section was chosen in order to compare Palaeozoic strata (primarily Devonian and Carboniferous successions) with successions in western Mongolia (Hushoot Shiveetiin gol section, Munkhjargal et al. 2021) and to generally increase the resolution of the biostratigraphy, lithostratigraphy, and sedimentology of this important section. In late July and early August 2019, the group measured sections from the Ordovician, Silurian to Devonian, and Carboniferous (Mississippian) near the Olon Ovoot gold mine (N 44 09' 44"; E $104^{\circ} 22^{\prime} 28^{\prime \prime}$ ). More than $1 \mathrm{~km}$ of section was measured (some parts of the section were summarized due to very rare facies differences), and about $610 \mathrm{~m}$ was measured in detail. Selected conodont samples were processed in the field with the hope of obtaining preliminary biostratigraphic information of critical intervals within the section. Overall, the fauna of the Bayankhoshuu Ruins section is scarce and fossils are poorly preserved due to tectonic overprint except some distinct horizons in the lower Mississippian.

This contribution presents results of the fieldwork, which supply an insight into the complex geology of the southern Gobi of Mongolia and provide additional information on the placement of the succession within the Palaeozoic Terrane scheme for Mongolia. Furthermore, this report provides new information of the complex relationships between the sedimentary and volcanic 
sequences in the Bayankhoshuu Ruins area, southern Mongolia. Additionally, the team hopes that work in progress can also provide insight into global Palaeozoic events by providing detailed analyses of sequences that were previously known only generally.

\subsection{Palaeozoic Terranes in Mongolia}

The CAOB is the world's largest Palaeozoic accretionary orogenic belt, and likely evolved in a similar fashion to the modern Pacific. Windley et al. (2007) favored an island archipelago model similar to modern Indonesia for island arc terranes in the CAOB including Mongolia. This accretionary system has evolved over at least 800 million years, from the Neoproterozoic time until the Cenozoic (Safonova et al. 2017). The CAOB formed by the suturing of the PalaeoAsian Ocean (PAO) and multi-stage Palaeozoic collisions of the East European, Siberian, North China, and Tarim cratons. The subduction of the PAO continued during the Middle and Late Palaeozoic before final closure of this ocean and its Turkestan and Junggar branches during the Late Palaeozoic to the Mesozoic (Windley et al. 2007; Donskaya et al. 2013; Yang et al. 2015; Safonova et al. 2017). Mongolia lies in the center of the CAOB. Badarch et al. (2002) recognized 44 different terranes-cratonic, metamorphic, passive margin, island arc, forearc/backarc, accretionary complex, or ophiolites ranging in age from the Proterozoic through the Phanerozoic. The Devonian was one of the primary times of terrane accretion. Traditionally, Mongolia is divided into a northern and southern domain by the Main Mongolian Lineament, which separates dominantly Precambrian and Lower Palaeozoic rocks to the north from Lower and Upper Palaeozoic rocks to the south (Fig. 1).

We conducted fieldwork in the northern part of the Gurvansayhan Terrane (Fig. 1, \#8) or in the southernmost part of the Mandalovoo Terrane (Fig. 1, \#2) in the scheme of Badarch et al. (2002). The geographic location of the field area is on the terrane boundary as drawn by Badarch et al. (2002). These two terranes are separated from the Idermeg Terrane by the Gobi Altai Terrane (Fig. 1, \#1). The terrane descriptions below are summarized from Badarch et al. (2002).

The Idermeg Terrane formed in the Neoproterozoic to Cambrian and is interpreted to represent a Palaeozoic passive continental margin. The post-accretionary complexes include Devonian to Permian and Triassic-Jurassic volcanic and sedimentary rocks, and minor limestone. The backarc/ forearc basins contain dominantly Lower Palaeozoic thick volcaniclastic and sedimentary successions, and minor mélanges of ultramafic and volcanic rocks. This terrane is mainly distinguished by their proximity to island arcs, by their composition and thickness of basin sediments, and by their geochemical signatures of volcanic rocks.

The Gobi Altai Terrane is a narrow terrane, located south of the Idermeg Terrane. It consists of Cambrian (?) greenschist facies metamorphosed sandstone, mudstone, tuff, and minor volcanic rocks, Ordovician to Silurian sandstone, argillite, shallow-marine fossiliferous limestone, minor conglomerate, olistostrome, Devonian-Mississippian conglomerate, sandstone, siltstone, fossiliferous limestone, pillow basalt, andesite and tuff, overlain by Pennsylvanian, Permian- 
Triassic volcanic and sedimentary rocks. The Ordovician-Silurian sandstones are mostly mature and quartzitic. Uppermost Silurian conglomerates contain plutonic and volcanic clasts.

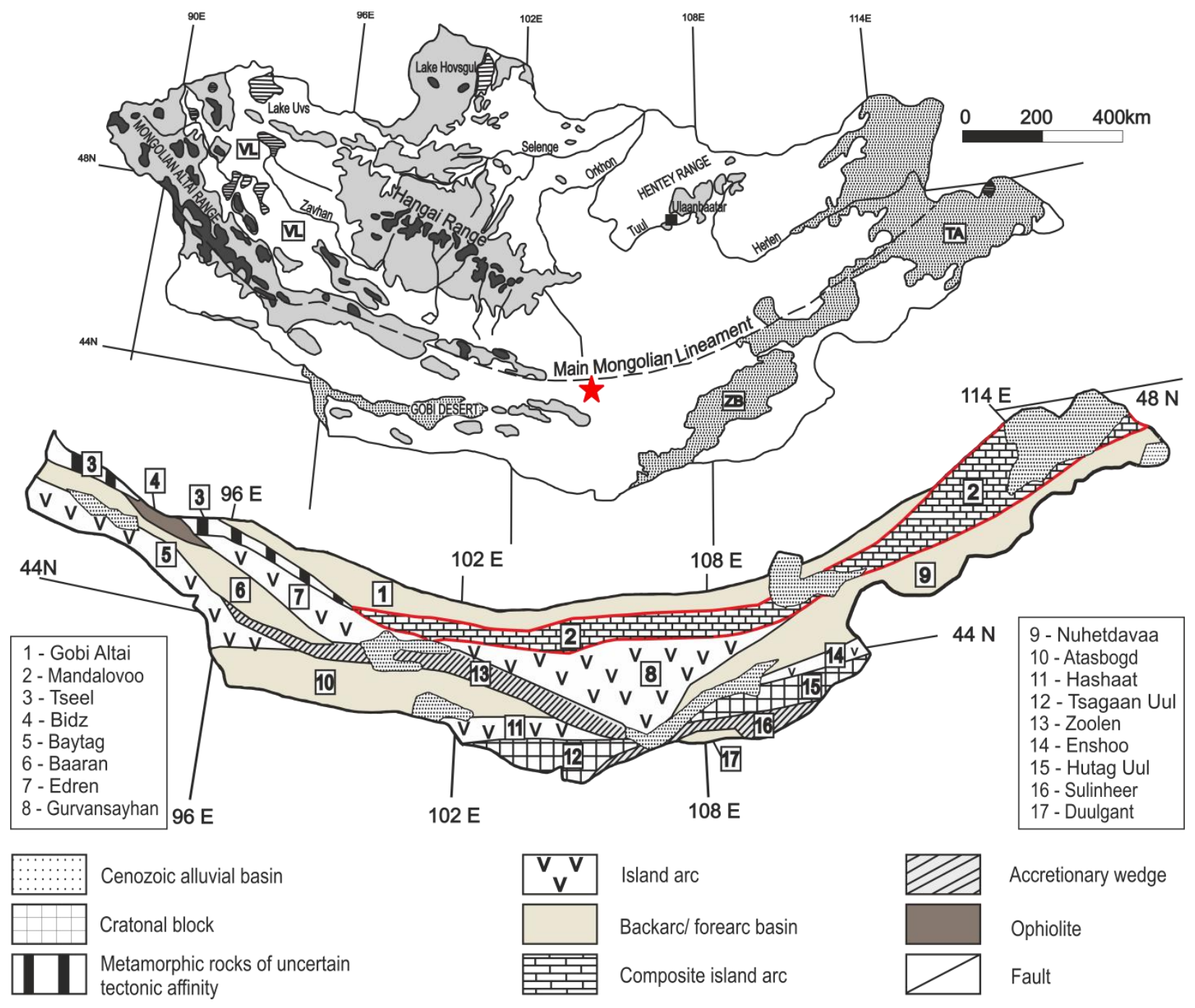

Fig. 1 Topographic map of Mongolia with location of the Main Mongolian Lineament and the southern structural units/terranes south of the Main Mongolian Lineament. Modified after Badarch et al. (2002). Asterisk marks the research area.

The Mandalovoo Terrane and the Gurvansayhan Terrane (Fig. 1) are island arc terranes and consist mainly of ophiolites, tholeiitic to calc-alkaline volcanic and volcaniclastic rocks. The Mandalovoo Terrane is a narrow belt which lies to the south of the Idermeg Terrane. It contains a stratigraphic succession of Ordovician to Carboniferous volcanic and sedimentary rocks including Ordovician and Silurian sandstone, argillite, fossiliferous limestone, Lower-Middle Devonian conglomerate, sandstone, shallow-marine fossil-rich limestone, felsic tuff, Upper Devonian pillow basalt, andesite, tuff, volcaniclastic sandstone, chert, and Mississippian (Lower Carboniferous) marine sedimentary rocks. Geochemical data from pillow lavas indicate that the basalts were erupted in a subduction zone setting (Lamb and Badarch 2001). Palaeomagnetic 
results suggest that the Devonian volcanic arc was near the Palaeoequator and drifted $40^{\circ}$ northwards and was rotated $75^{\circ}$ clockwise (Fig. 2; Safonova et al. 2017).

The Gurvansayhan Terrane lies south of the Mandalovoo Terrane and is bordered by the Zoolen accretionary wedge in the southwest (Fig. 1). The terrane is composed of ophiolites, mélanges, Ordovician-Silurian greenschist facies metamorphosed sandstone, argillite, chert, volcaniclastic rocks, Upper Silurian-Lower Devonian radiolarian chert, tholeiitic pillow basalt, andesite, tuff, Middle Devonian-Mississippian volcaniclastic rocks, chert containing Frasnian conodonts, and minor olistostrome with coral limestone clasts. The major and trace element geochemistry of Devonian basalt indicate volcanism in an arc environment (Ruzhentsev et al. 1992; Lamb and Badarch 2001). The structure of the terrane is complex and dominated by imbricate thrust sheets, dismembered blocks and mélanges containing pillow lavas, fossiliferous limestone, sandstone, gabbro, diabase dykes, and amphibolite. The terrane is overlain by Carboniferous, Permian, Jurassic, and Cretaceous volcanic and sedimentary rocks.

Within the model proposed by Badarch et al. (2002) and modified by Helo et al. (2006), the Idermeg Terrane formed a cratonic nucleus around which younger terranes accreted. The Gobi Altai Terrane is made up of remnants of a rejuvenated old microcontinent associated with a backarc basin similar to a Japan-type magmatic arc. The Gurvansayhan Terrane has an origin in a juvenile island arc forearc setting. The accretion history of the terranes is complex with no simple north-to south progression of volcanism. In the Gurvansayhan Terrane, existing age data suggest a south-to-north accretion.

\subsection{CAOB and intra-oceanic arc systems}

Safonova et al. (2017) recognized 21 intra-oceanic arc systems in the CAOB associated with the closure of the Palaeo- Asian Ocean and its branches. Intra-oceanic arcs (IOAs) form at Pacifictype convergent margins, in the upper plate, when the subducting plate submerges to the depths of melting, i.e., to ca. 50-100 km. Based on publications by Badarch et al. (2002) and Helo et al. (2006), Safonova et al. (2017) identified an intra-oceanic arc in the Gurvansayhan-Zoolen terranes dating from the Late Silurian-Late Devonian (Fig. 3, \#17). The Gurvansayhan-Zoolen arc extends for a distance of more than $800 \mathrm{~km}$, making it one of the longest intra-oceanic arc systems in the CAOB. The Gurvansayhan island arc terrane is dominated by Silurian-Devonian island arc tholeiites and andesites and Middle Devonian volcaniclastic rocks. The arc units are covered by middle Carboniferous terrigenous sediments. The Zoolen Terrane was regarded as accretionary by Badarch et al. (2002), but Helo et al. (2006) interpreted it as an island arc.

The Zoolen Terrane is ca. $500 \mathrm{~km}$ long and up to $80 \mathrm{~km}$ wide. The volcanic rocks of the Gurvansayhan and Zoolen terranes are dominated by andesitic and basaltic varieties of boninitic, tholeiitic, and calc-alkaline series. The basalts have low $\mathrm{TiO} 2(0.5-1.3 \mathrm{wt} \%)$ and high $\mathrm{Mg}$, indicating near primary mantle-derived compositions. The andesites are moderately fractionated with Mg numbers of 50-60. There are andesites with high $\mathrm{MgO}(7.1 \mathrm{wt} \%)$ and $\mathrm{SiO} 2$ (60 wt\%), i.e., similar to boninites (Helo et al. 2006). The calc-alkaline volcanics (andesites to rhyolites) 


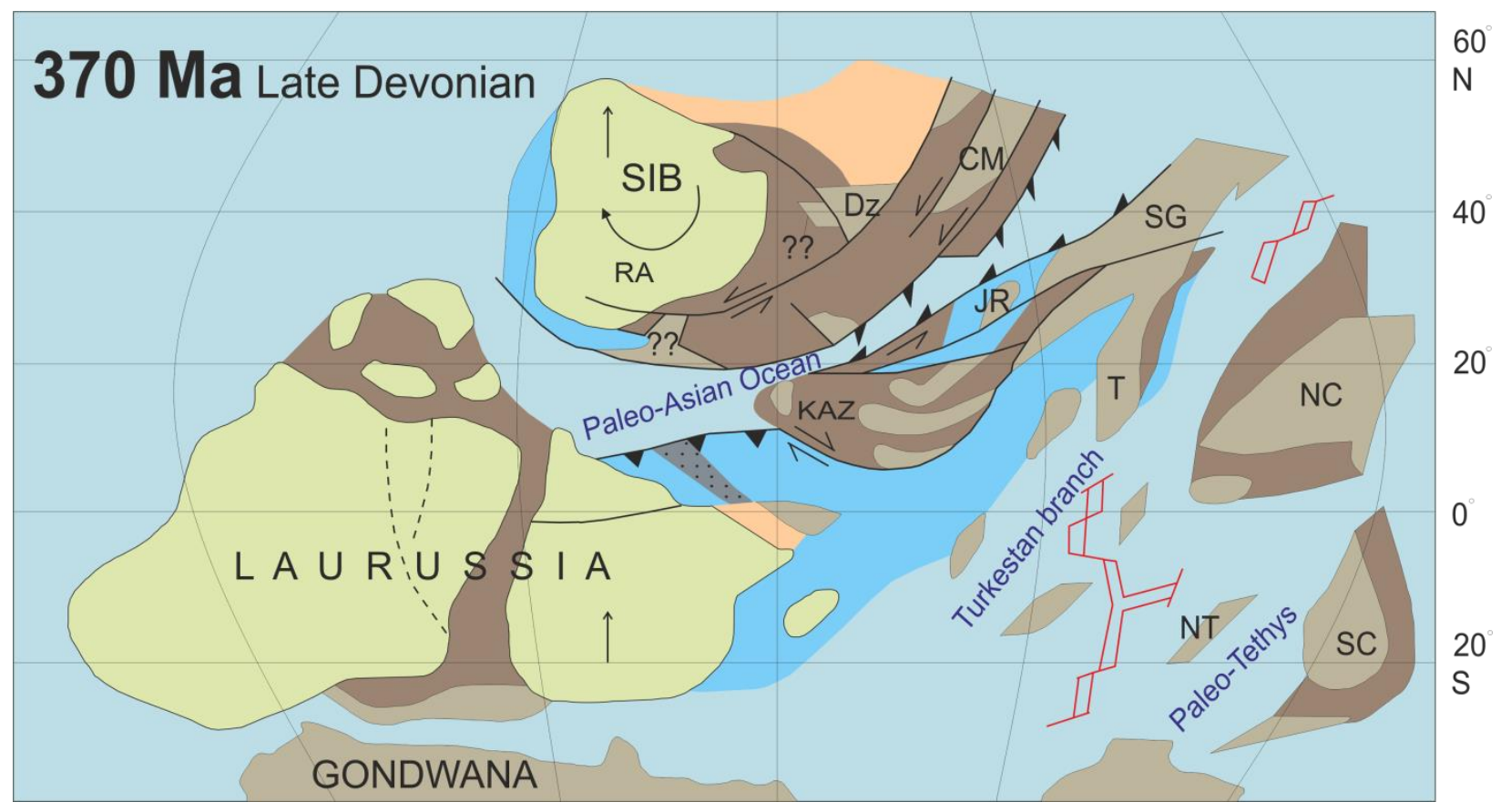

Fig. 2 Plate tectonic reconstruction of the Palaeo-Asian Ocean during the Late Devonian published in Safonova et al. (2017; see references therein). Abbreviations for continental blocks: CM, Central Mongolia; Dz, Dzabkhan (Baydrag); SG, South Gobi; JR, Junggar; KAZ, Kazakhstan; NC, North China; NT, North Tienshan; ST, South China; RA, Rudny Altai; SIB, Siberian Craton. South Gobi at that time is placed around $40^{\circ}$ to the north.

are characterized by differentiated REE and concave HREE patterns which is typical of thick and mature island arcs. The tholeiitic basalts have low $\mathrm{Th} / \mathrm{Nb}(0.3)$ and low-enriched LREE (Helo et al. 2006) suggesting a very small amount of recycled sediments that is typical of immature island arcs (Stern and Scholl 2010). The Gurvansayhan and Zoolen volcanics are enriched in light REE and depleted in HFSE. Conclusively, the geochemical data in combination with high initial $\varepsilon N d-$ values of ca. +6 to +9 (Helo et al. 2006; Table 2) are consistent with a juvenile intra-oceanic arc. There are also volcanic varieties compositionally similar to adakites, which, together with boninites, suggest a forearc setting. The volcanic rocks from adjacent terranes (Gobi Altai) also have high initial $\varepsilon N d$ values $(+6$ to +10$)$ and exhibit calc-alkaline, LREE-enriched island arc as well as tholeiitic LREE-depleted back-arc basin signatures of predominantly juvenile composition (Helo et al. 2006). The formation of the Gurvansayhan and Zoolen arc terranes is attributed to the evolution on the South Mongolian branch of the Palaeo-Asian Ocean (Zonenshain et al. 1975; Dobretsov et al. 1995; Buslov et al. 2001).

\section{Material and methods}

Most units which contain sediments were measured bed by bed at centimeter scale. A large number of rock samples were taken for microfacies analysis, geochemical analysis, and biostratigraphy. For the report presented herein, biostratigraphy is mainly based on conodonts (including collection data reported from that area) and radiolarians. Fifty-one conodont samples of approximately $2-4 \mathrm{~kg}$ each were taken from calcareous rock and limestone and processed by 
standard methods (see Jeppson and Anehus 1995). This process was repeated until samples were dissolved. Washed residues were dried in an oven and later sieved and separated into three fractions. Overall, conodonts are scarce and not well-preserved and very often lack agediagnostic species except those conodonts found in pure limestone in the Mississippian. In addition, we carefully examined previously published collections stored in Mongolia. As a result of new biostratigraphic data and revision of previous conodont collections, we can improve the biostratigraphy of the Bayankhoshuu Ruins section. Conodont zonation schemes follow Lane et al. (1980), Corriga et al. (2009), Hartenfels (2011), and Spalletta et al. (2017). As it is common practice in conodont studies, only $\mathrm{Pa}$ elements were identified. Chert samples were processed, but yielded few radiolarian species. All conodont and radiolarian samples will be stored at the Mongolian University of Sciences and Technology, Ulaanbaatar, Mongolia, under repository numbers (MUST-RCSP-CON-0041 to CON-0064 MUST-RCSP-RAD-0001 to RAD-0013).

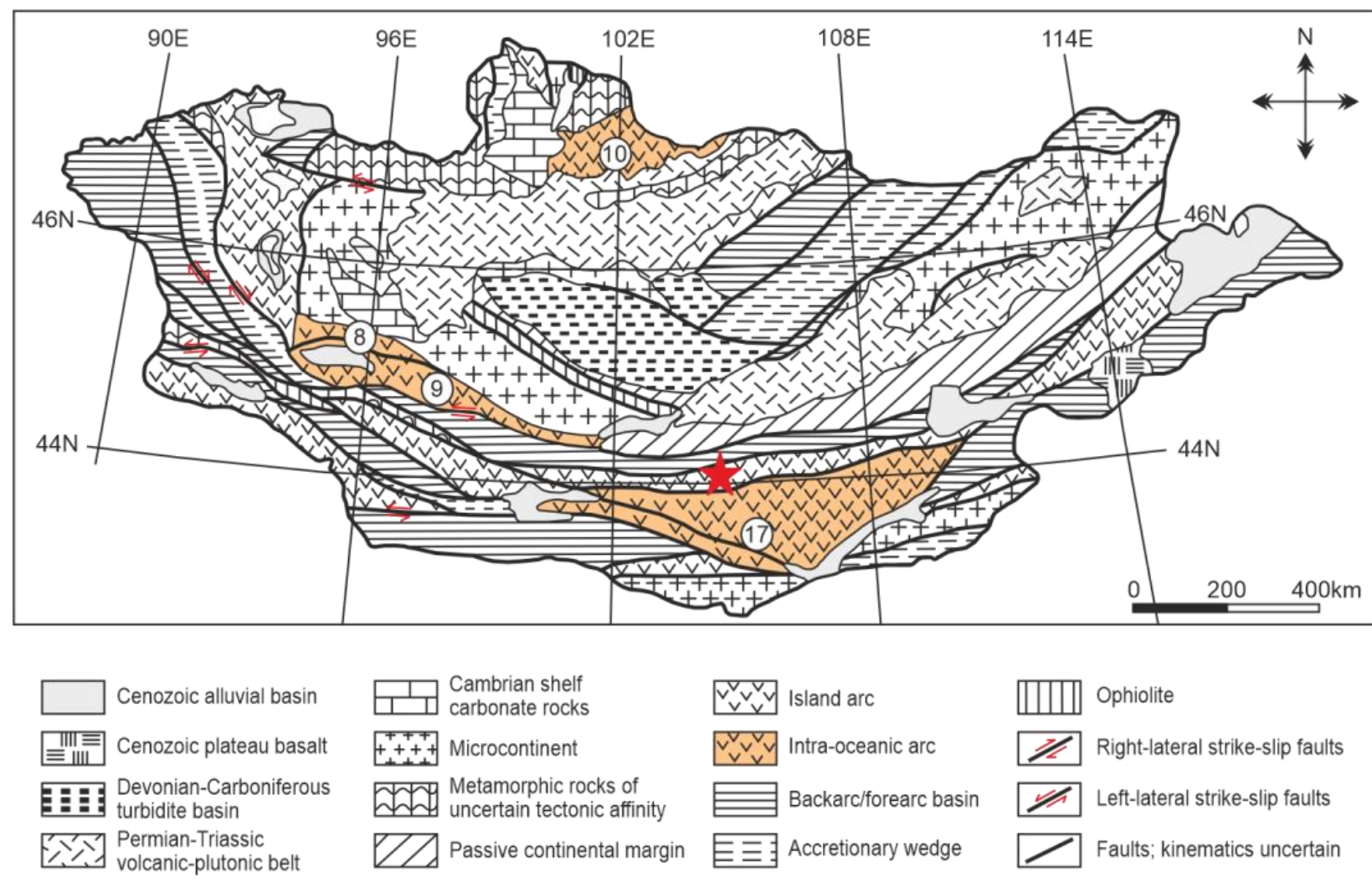

Fig. 3 Main terranes of Mongolia (modified after Badarch et al. 2002), published in Safonova et al. (2017). The numbers in circles indicate intra-oceanic arcs and their hosting terranes: 8, Dariv; 9, Khan-Taishirin; 10, Dzhida; and 17, Gurvansayhan-Zoolen terranes.

Because the primary objective of the fieldwork was to characterize the sedimentary sequence in more detail than previously reported (Minjin et al. 2001, Wang et al. 2003a, b, 2005), sampling of the Minjin Member was undertaken as an ancillary part of the fieldwork. Facies and microfacies types (FT) were mainly compared on the basis of the classical models provided by Wilson (1975) and Flügel (2004); the description of siliciclastic rock follows the classification 
published in Folk (1954), Pettijohn et al. (1973), and Tucker (2001). For this overview, 57 thin sections of $7.5 \times 11 \mathrm{~cm}$ in size were used. Thin sections are stored at Senckenberg Research Institute and Natural History Museum Frankfurt, Germany, under repository numbers (SMF 99332-SMF 99391). All samples were taken along detailed measured sections and were incorporated into the lithological logs presented herein. Some sections represent compiled sections, and samples were taken where visual differences in composition or texture could be observed. GPS readings $( \pm 3 \mathrm{~m})$ record each sample location.

\section{Results}

3.1. Regional geology-Bayankhoshuu Ruins area

The different formations of the Bayankhoshuu Ruins section are briefly described in stratigraphical order from the oldest to the youngest successions based on published data (Guidebook for the 2001 joint meeting of IGCP 410 and 421, Minjin et al. 2001; Wang et al. 2003a, b, 2005) and on new data obtained during fieldwork in 2019. In Fig. 4, we present a geological map of the area, which is based on published data (Minjin et al. 2001; Wang et al. 2005) and data that resulted from this study. We focused on Ordovician/Silurian, Middle to Late Devonian, and Mississippian rocks in order to get a better understanding of the complex relationships between the sedimentary and volcanic sequences as well as on events in the Palaeozoic of Mongolia. Biostratigraphy is mainly based on conodonts and some radiolarians, which generally support conodont data.

The color alteration of conodonts (CAI; Epstein et al. 1977) is high in most samples and ranges from CAI 4.5 to CAI 6. Conodonts found in the Mississippian exhibit lower CAI values, around CAI 3.5 to 4.0. Most samples are barren, but conodonts were found in a limited number of samples. Many conodonts are fractured and incomplete. Due to the facies setting and diagenesis (silicification, recrystallization), processed samples yielded large volumes of residue.

The location of the sections we investigated in detail is shown in Fig. 4. Most strata are intensively folded and faulted. We have sampled three sections (A to C; see Fig. 4), ranging from the Late Ordovician to Silurian (Fig. 5) along a road west of the Olon Ovoot gold mine and a cross-section near the Bayankhoshuu Ruins (Middle Devonian to Early Carboniferous) further in the north (Fig. 4). The latter one is subdivided into different sections which are characterized by a mixture of sedimentary rocks, volcanic rocks (basalts, pillow basalts, ?andesites, felsic volcanics), and volcaniclastic rocks (bentonites). The overall lithology of the rocks indicates some sort of island arc setting rather than a passive margin setting. Geographically, the locality is south of the Main Mongolian Lineament by $100 \mathrm{~km}$. The section is not consistent with deposition on the Idermeg Terrane or the Gobi Altai Terrane. Deposition likely occurred on either the Mandalovoo or Gurvansayhan Terrane. The geographic location of the field area is on the terrane boundary as drawn by Badarch (2002). Both terranes have similar origins. 


\subsection{Khoyormod Formation}

The Khoyormod Formation outcrops $400 \mathrm{~m}$ west from the Bayankhoshuu Ruins (Fig. 4) and downhill from outcrops of Upper Jurassic volcanic rocks and was first described by Minjin (2001). The reported thickness of this member is about $400 \mathrm{~m}$, but our measured section of the formation only records a few tens of meters (Fig. 5), perhaps the result of thrusting. Parts of the Khoyormod Formation are exposed west of the field camp in section A (Fig. 5). This formation is represented by an alternation of gray, greenish-gray mudstone, sandstone with limestone lenses, and some fossiliferous limestone. These limestones contain crinoids and corals such as Karagemia altaica and Khangailites hetermorphosus. The fauna is widely distributed in Upper Ordovician carbonate facies in Mongolia.

A number of limestone samples were taken for conodont biostratigraphy (Fig. 5), but all samples were barren except sample BR-C-2. Conodont fauna from the Late Ordovician Khoyormod Formation did not yield diagnostic conodonts of the Amorphognathus ordovicicus biozone, which is attributed to the Ordovician Extinction Event (Hirnantian) but yielded one conodont element of Walliserodus cf. amplissimus or Hamarodus sp. The predominance of Walliserodus amplissimus species represents a characteristic species which occurs in the Hirnantian in Europe (e.g., Ferretti and Serpagli 1999; Rodriguez-Canero et al. 2010). Sediments are characterized by an alternation of crinoidal grainstone, echinoderm packstone, wackestone, and floatstone (Fig. 6a-d; Fig. 7a, b). Crinoidal grainstone layer can reach a remarkable thickness of several decimeters to meters. The entire section is fractured from millimeter to decimeter size and is characterized by rocks which underwent strong tectonic strain and overburden which resulted in solution seams and brecciated fabric (Fig. 6a-c). It is interesting to note that facies change occurs in the middle part of the sampled Khoyormod Formation. Gray limestones with iron-stained micritic matrix with hematite nodules conformably overlay micritic limestone and crinoidal grainstone (Figs. 5 and 6d).

\subsection{Mandalovoo Formation}

Gavuu Member: The Gavuu Member comprises micritic limestone (up to $100 \mathrm{~m}$ thick), nodular limestone, and intercalations of thin-bedded siltstone. The limestone yielded corals such as Favosites gothlandicus, F. kennihoensis minus, and Catenipora minuta indicating a Llandoverian age (Minjin et al. 2001). Other fauna, such as conodonts (e.g. Ozarkodina inclinata inclinata) are reported from the same authors.

In our section the Gаvии Member is represented by a reduced sedimentologic record and exhibits mainly massflow deposits in section "B" which are covered by thin-bedded siltstone, sandstone, crinoidal grainstone, and basalt (Fig. 5).

Conodont samples are barren and macrofauna, such as corals, are scarce. But conodonts from the area were described by Vorozhbitov (1997). This author described the conodonts Ozarkodina

excavata excavata and Kockelella ranuliformis from the Gornyi Altai as well as from the Gavuu 
Member in the Havtsal section in the Mushgai area, which is an important determination. Whereas Ozarkodina excavata excavata is recognized as a long-ranging species (e.g., Klapper and Murphy 1975), Kockelella ranuliformis is the name-bearing species for the Kockelella ranuliformis conodont biozone in the Sheinwoodian (early Wenlock; e.g., Corriga et al. 2009). The fauna from the Mushgai area suggests a stratigraphical range from Llandovery to early Wenlock for the Gavиu Member. The stratigraphical range of the conodont species Kockella ranuliformis is important in terms of events in the Late Palaeozoic insofar as the Ireviken Event (late Telchian-Sheinwoodian) coincides with a profound change in the pattern of sedimentation, from the shale-dominated units of the Pterospathodus amorphognathoides conodont biozone worldwide to the pure carbonates of the overlying Kockelella ranuliformis biozone, which has

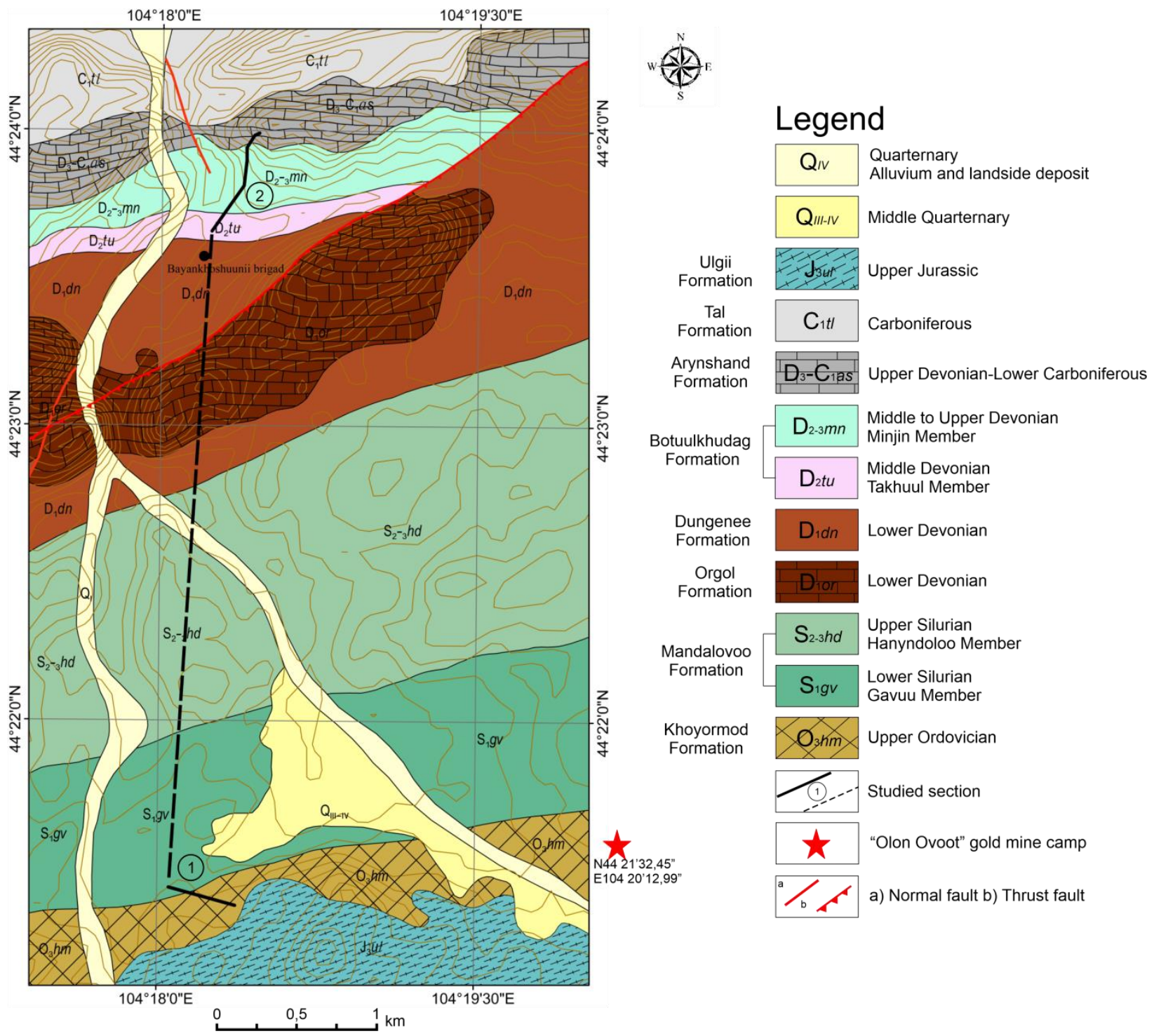

Fig. 4 Geological map of the working area (Mushgai, southern Mongolian Gobi, Umnugobi Province, Mandalovoo area) and the sections investigated (the stippled line represents those parts of the section we have summarized). Study area \#1 is composed of three sections (hills A-C, Ordovician to Silurian rocks; see lithological log Fig. 5); 
area \#2 is composed of three sections (Lower Devonian to Mississippian rocks; see lithological logs Figs. 8, 11, and 12).

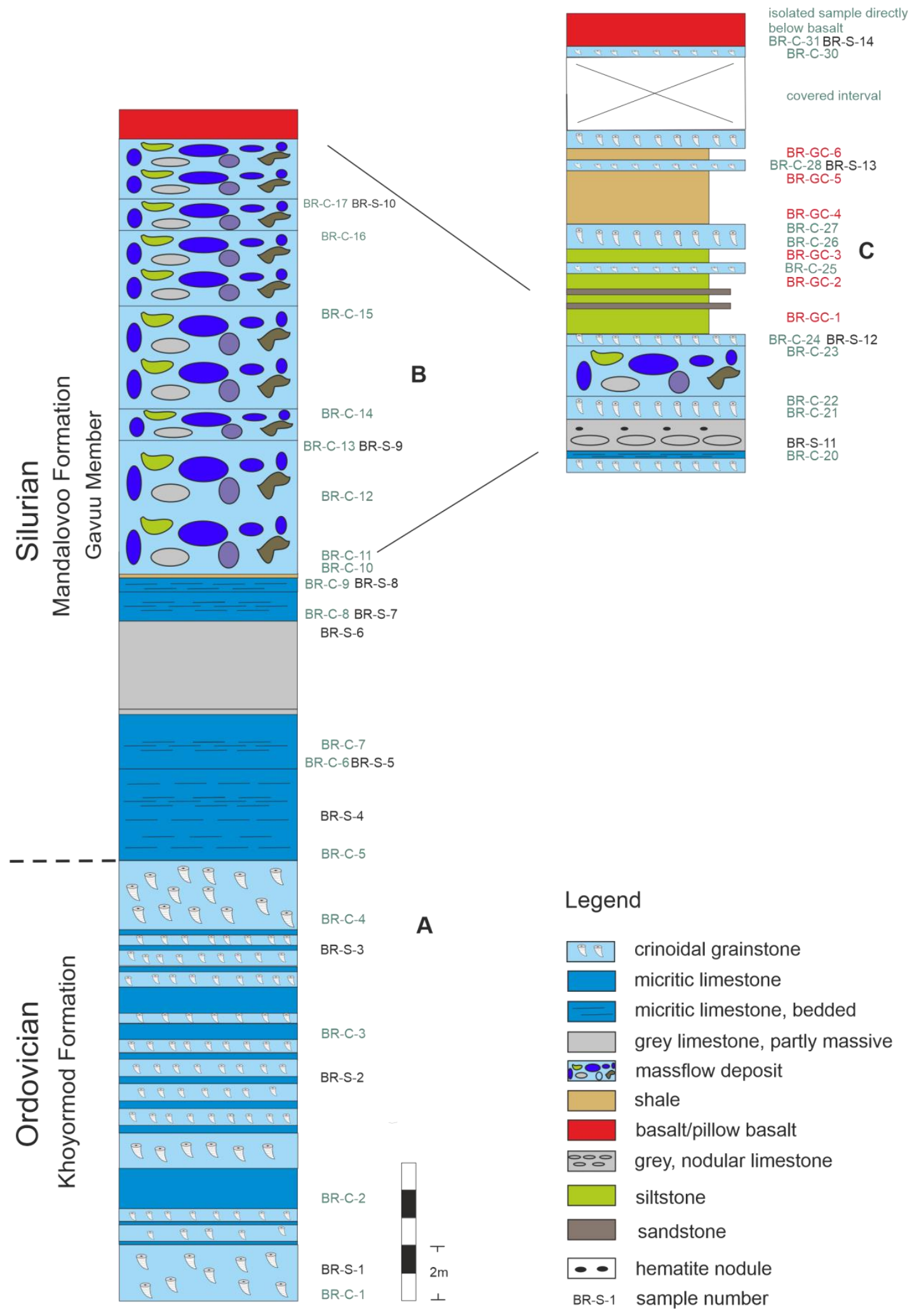


Fig. 5 Compiled lithological log of three hills (sections A to C, \#1 in Fig. 4) along the road west of the Olon Ovoot gold mine (Khoyormod Formation, Ordovician; Mandalovoo Formation, Gavuu Member, Silurian), Bayankhoshuu Ruins area, Umnugobi Province. Sample numbers: "C" = conodont samples, "S" = sedimentology/facies, "GC" = samples for geochemistry.
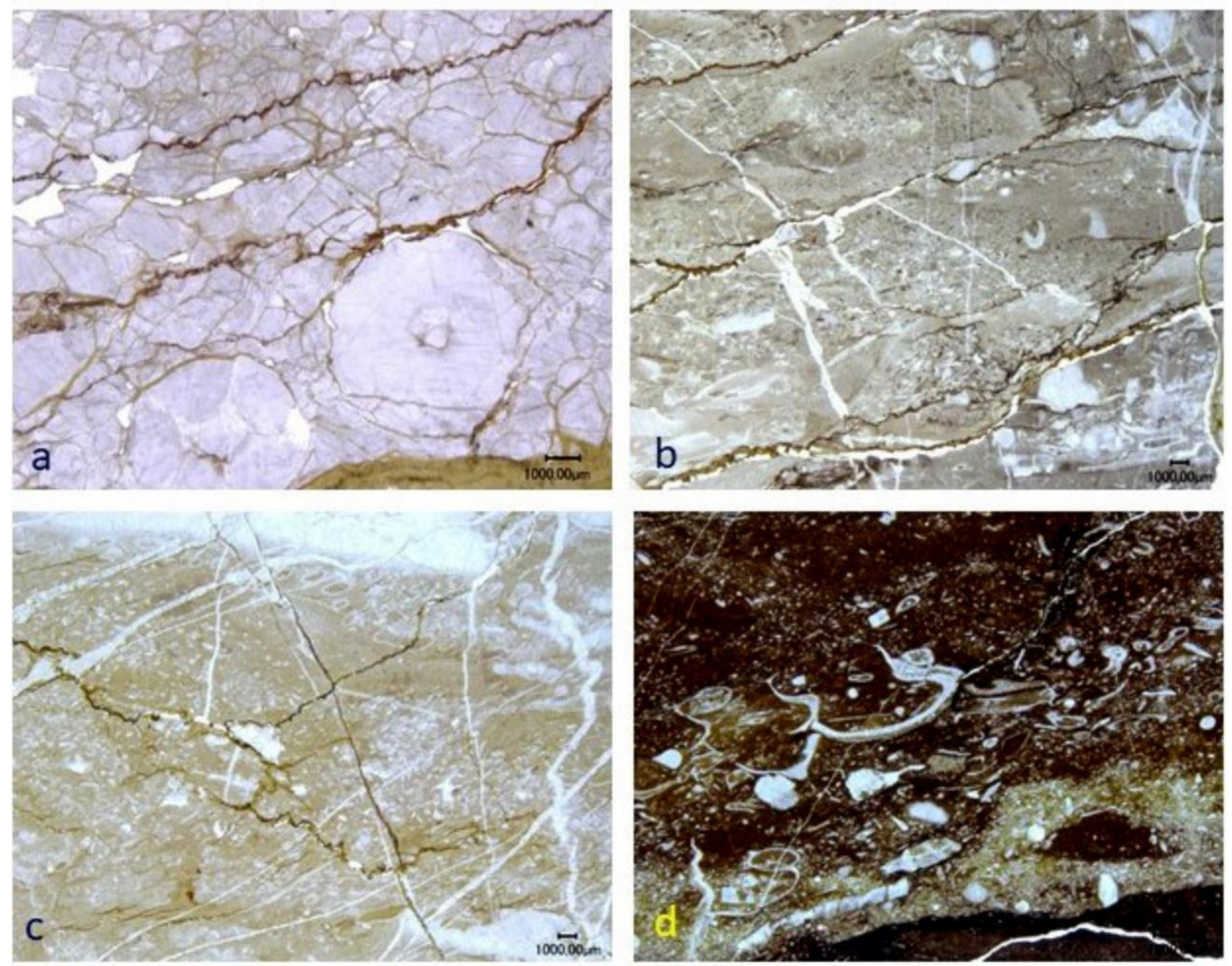

Fig. 6 Microfacies of the Khoyormod Formation; a echinoderm packstone shows a condensed fabric. The parallel set of stylolites originates from selected pressure solution. The components produce a puzzle-like fabric and are surrounded by solution seams (sample BR-S-1); b fossiliferous micritic limestone with irregular anastomosing set of stylolites underlain by a fossiliferous limestone with corals and echinoderms (sample BR-S-5); c fossiliferous wackestone with micritic matrix. The sediment is slightly burrowed and shows an irregular anastomosing set of stylolites (sample BR-S-6); d floatstone with large bioclasts (e.g., trilobites, echinoderms, brachiopods), small shell hash, and rare corals and bivalves. The iron-stained matrix is clayey to micritic (sample BR-S-4).

been interpreted to reflect the largest-magnitude eustatic event of the entire Silurian (Johnson 1996; Barrick 1997; Salzmann 2001; Zhang et al. 2017). This lithologic change has been interpreted as the largest worldwide regression of the Silurian (Johnson 1996; Barrick 1997). Johnson (2006) pointed out that the Ireviken Event took place during the whole regression, which is supported by a hiatus and a sequence boundary reported from East Baltic area by Nestor et al. (2002) and Loydell et al. (2003). In our section, this transition may correlate with the transition from micritic limestones to mass-flow deposits (Fig. 5), but the diagnostic conodonts 
such as Kockella ranuliformis have not been found in this section so far. Further, studies on detailed stratigraphy and geochemical analysis are necessary (work in progress) to confirm the biostratigraphic results by Vorozhbitov (1997).

Hanyndoloon Member: The folded sediments of this member were described in the 2001 IGCP field guidebook from the area (Minjin et al. 2001). The transition from the calcareous sediments to more siliciclastic sediments may be exposed in the small section \# 1C (Figs. 4 and 5), but the transition to the overlying greywacke is not exposed in the studied section.

Greywacke beds can reach thicknesses of several meters and exhibit characteristic sedimentological features such as graded bedding, load casts, and flute casts (Fig. 7c). The Hanyndoloon Member is composed of green mudstone, sandstone, and greywacke, the latter having a thickness of about $600 \mathrm{~m}$. The lower and upper contacts of this formation are not exposed and are believed to be of tectonic origin (Minjin et al. 2001). According to Minjin et al. (2001), the Hanyndoloon Member has a stratigraphical range from Ludlow to Pridoli. This part of the section was not sampled in detail (see stippled line in Fig. 4) and is not shown in the lithological logs.

\subsection{Orgol Formation}

The Orgol Formation was first described and named by Minjin et al. (1993). Wang et al. (2003a, b, 2005) preferred to use the name Olonovoot Formation based on new conodont findings in samples M-9 to M-12 (Wang et al. 2005) of the Bayankhoshuu Ruins section. The base of this formation is mainly composed of "conglomeratic limestone" which has a thickness of 70-100 m.

The stratigraphical range of this formation is still in discussion. Several spot samples with different fauna were taken along a cross-section near the Bayankhoshuu Ruins (e.g., Wang et al. 2003a, b; Wang and Chuluun 2004), but the exact sample position in older publications remains uncertain in some cases as the authors took spot samples to get an idea on the stratigraphy; a detailed measured section was beyond their aim. However, tabulate and rugose corals reported from bioherms of the Orgol Formation such as Favosites socialis, Pachyfavosites subnitellus, P. gicinger, Thamnopora solida, Striatopora longa, Cladopora sp., Hellaeopora sp., Lecomptia sp., Caliopora sp., and rugosans such as Spongophylloides perfecta, and Spongophylum halysitoides indicated a Lochkovian age. Another spot sample comes from the lowermost limestone layer of

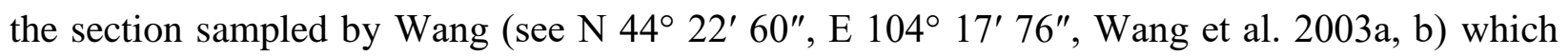
yielded the important conodont species Caudicriodus woschmidti which indicates also Lochkovian age. Similar results were reported by Minjin and Tumenbayar (2001). The Caudicriodus woschmidti (or C. hesperius) conodont biozone has been recognized as the lowermost unit of the Devonian, and its base as the Pridoli/Lochkovian boundary. Wang et al. (2003a, b) found the conodont Pandorinellina exigua which suggested an early Emsian age as the earliest occurrence of this species is from the base of the early Emsian (Murphy et al. 2004). The disadvantage of the identification by Wang et al. (2003a, b, Plate 1, Fig. 6) is that the authors did not figure the critical parts of the Pa elements that are necessary for identification, 
the basal views of the Pa elements. Thus, a stratigraphic range into the Emsian is questionable. From our point of view, the Orgol Formation is of Lochkovian in age which is overlain by the Pragian to Emsian Dungenee Formation. Whether the contact between both formations is conformable or whether it is a tectonic contact remains questionable.
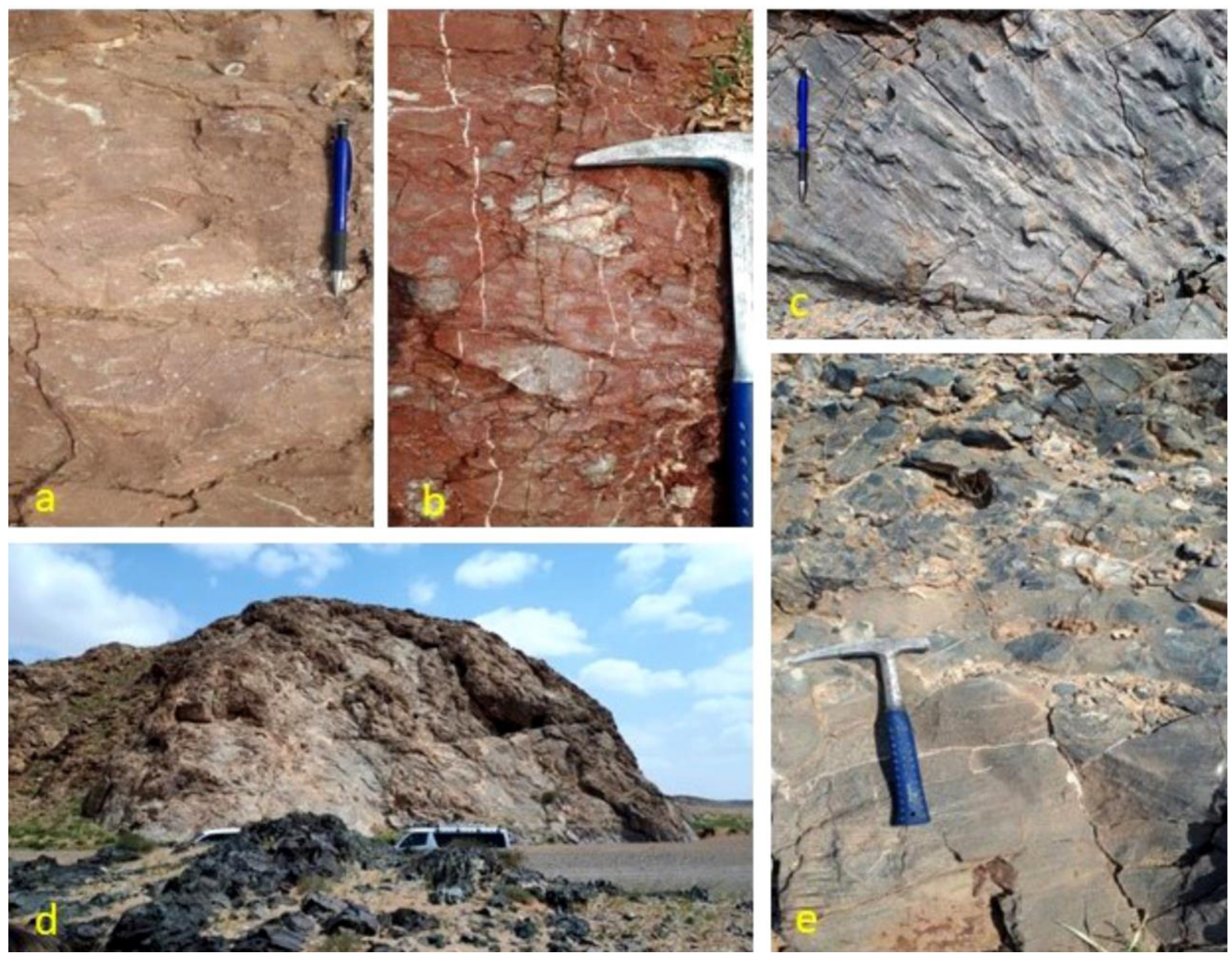

Fig. 7 Field photographs showing lithological units and sedimentological features observed in the Bayankhoshuu Ruins section, Mandalovoo Formation: a alternation of reddish crinoidal grainstone and micritic limestone of the Ordovician Khoyormod Formation (Bayankhoshuu Ruins area, Umnugobi Province; photo taken close to sample BR-S-2). b massflow deposits of the Gavuu Member with reworked corals (Mandalovoo Formation; photo taken from sample close to BR-S-7). c Greywacke with flute casts at the lower surface, Hanyndoloon Member (Mandalovoo Formation, cross-section near the Bayankhoshuu Ruins). d Bioherm of the Orgol Formation, crosssection near the Bayankhoshuu Ruins, Umnugobi Province; the Dungenee Formation is shown here in front of the Orgol Formation. e Sandstone and conglomerate of the Takhuul Member, Botuulkhudag Formation (cross-section near the Bayankhoshuu Ruins, Umnugobi Province; photo taken from the base of the section around sample BR-S$15)$.

\subsection{Dungenee Formation}

The Dungenee Formation can be subdivided into two units. A lower unnamed sandstone unit is composed of sandstone and some grayish limestone layers (50 m thick). From the fossiliferous limestone, the following fossils are reported: brachiopods (Cymostrophia (?) sp.), tabulate corals 
(Favosites admirabilis, Caliopora sp., Coenites sp.), rugose corals (Pseudomicroplasma compositum), crinoids, bryozoans, and gastropods. The fauna indicates a Pragian to Emsian age. The thickness of this succession is about $400 \mathrm{~m}$ (Fig. 4).

The upper part of the Dungenee Formation is named the Murugtsug Member and is composed of dark-gray, greenish-gray, gray, massive-bedded, and medium-thin-bedded fossiliferous limestones. The following fossils are reported (Minjin et al. 2001): crinoids such as Syndetocrinus natus, Pandocrinus pandus, Crotalocrinites cf. rugosus, brachiopod (Atrypa sp.), tabulate corals (Favosites admirabilis, Pachyfavosites preplacenta, P. subnitellus, P. gicinger, Plicatomorus giganteus, Gerphuropora multiplicata, Yacutiopora sp., Thamnopora diserta, T. solida, Coenites dunginensis, C. sp., Caliopora sp.), and rugose corals (Pseudomicroplasma compositum, Embolophyllum agregatum, Spongophylloides tomasae, S. dubrovensis, and Spongophyllum halysitoides).

\subsection{Botuulkhudag Formation}

The Botuulkhudag Formation (Fig. 8) is divided into the Takhuul and Minjin members. The Takhuul Member conformably overlies the Dungenee Formation (Fig. 8). The base is Eifelian in age whereas the upper boundary is not well-defined (Wang et al. 2005). The total thickness of the Botuulkhudag Formation is $610 \mathrm{~m}$.

Takhuul Member: The Takhuul Member (Figs. 8 and 9a-h) in our section starts with siltstone overlain by a fine- to medium grained arkosic sandstone which is composed of quartz, feldspar, and some lithic clasts (Fig. 9a).

The clasts contain less than 10\%ofmatrix. Quartz grains and lithoclasts are angular to subangular and the sediment is moderately sorted. The majority of the Takhuul Member is composed of a polymict conglomerate with fine rounded pebbles and boulders (ranging from 5 to $40 \mathrm{~cm}$ in diameter, Figs. 7e and 9b); coarse- to fine-grained, gray to brownish calcareous sandstone; sandstone with sandstone pebble; reddish to brownish siltstone; and limestone. Limestone boulders often contain excellently preserved Early Devonian corals (Fig. 9b; Minjin et al. 2001) and may represent reworked material from the Orgol Formation. Occasionally, corals are overgrown by stromatoporoids (Fig. 9b). Due to strong recrystallization, species-level classification of the stromatoporoids is poorly constrained.

These fossiliferous wackestones (Fig. 9d-f) represent the majority of the boulders. Overall, the polymict conglomerate is composed of well-rounded sedimentary rocks of various sizes. Interestingly, the matrix itself is a polymict conglomerate as well (Fig. 9c) containing angular to well-rounded clasts of sandstone, siltstone, and limestone. The conglomerate covers a large area and has a thickness of $30 \mathrm{~m}$ (Fig. 8). The coarsening upward (siltstone-sandstone-conglomerate) sequence at the base of the Takhuul Member requires a high-energy environment. Deposition of conglomerates occurred most probably along a beach with strong waves. Furthermore, sedimentological analysis (size of samples, composition, and age) suggest an environment with a certain morphology/rapid uplift (cobble-size rocks) and/or sea-level changes of an appropriate 
magnitude. Whether this succession was linked with tectonic events (e.g., amalgamation of terranes) requires more detailed studies on other sections. The transition to micritic limestones at the top of this formation is not exposed (Fig. 8). Micritic limestones are covered by a thinbedded calcareous sandstone with angular to rounded clasts (Fig. 9g). This succession is overlain by black shale followed by limestones, shale, and a sandstone at the top of the Takhuul Member (Figs. 8 and 9h). According to Minjin et al. (2001), the Takhuul Member is of Eifelian in age. The earliest Eifelian was a time of relatively high eustatic sea-level (middle part of T-R cycle Ic sensu Johnson et al. (1985), Johnson and Sandberg (1989), and Walliser (1996)) related to the transgressive "Basal Chotec Event" (see Chlupac and Kukal 1986). Whereas the basal part of our section represents an overall shallow-water succession (coarsening-upward sequence), the transition from micritic limestone to black shale represents deeper water environment, which might be associated with the "Basal Chotec Event." At the time of writing this report, this is a hypothesis based on the remarkable lithological shift that requires more detailed stratigraphical and geochemical studies (work in progress). The Takhuul Member is conformably overlain by the Minjin Member. The transition to the next younger member was placed above thick-bedded quarzitic sandstone with the first bentonite bed of this section (Fig. 8).

Minjin Member: According to earlier descriptions (e.g., Minjin et al. 2001, Wang et al. 2005), the Minjin Member (Figs. 10, 11, and 12) is subdivided into two parts. The lower part is composed of dark-green tuff and lava with dark-gray lenticular limestones and is assigned to Givetian (Minjin et al. 2001). The middle and the upper parts of the Minjin Member are not composed of shale and sandstone as described in the guidebook (Minjin et al. 2001), but are siliceous mudstone, siltstone, and chert. The Minjin Member of the Botuulkhudag Formation is primarily a basaltic sequence with minor sediments except in the middle part of the section (Fig. 11) where radiolarian chert and siltstone occur. The Minjin Member in our section begins with an alternation of shale and bentonite. The latter can reach a remarkable thickness of several meters.

This section is covered by fine-grained basalt and pillow basalt. At the base of this succession, which has a thickness of approximately $330 \mathrm{~m}$, isolated micritic limestone boulders occur, which were sampled for conodonts but were barren. Thus, we refer to Minjin et al. (2001) who sampled the same limestone (sample BR-C-38 and BR-C39 in our section) and reported an early Givetian age of that part of the section.

Within the thick basalt succession (see Fig. 8), we have sampled a section in detail (Fig. 11) which is mainly composed of an alternating sequence of siliceous mudstone, siltstone, chert, and volcaniclastic rock (Figs. 8b-d, 9, and 11). The latter ones show components of magma as well as previously cemented rocks, such as cherts. Thin sections and hand samples exhibit normal and inverse gradation (Fig. 10d). This succession is covered by large pillow basalts (Fig. 10e) which reach diameters larger than $2 \mathrm{~m}$. This continuous succession (see \#2 of Fig. 4) ranges from the Givetian to ?early Frasnian based on conodonts and radiolarians found in the underlying and overlying sediments. 
The overlying unit (Fig. 12) is composed of shale, pyroclastic rock and silicified siltstone and

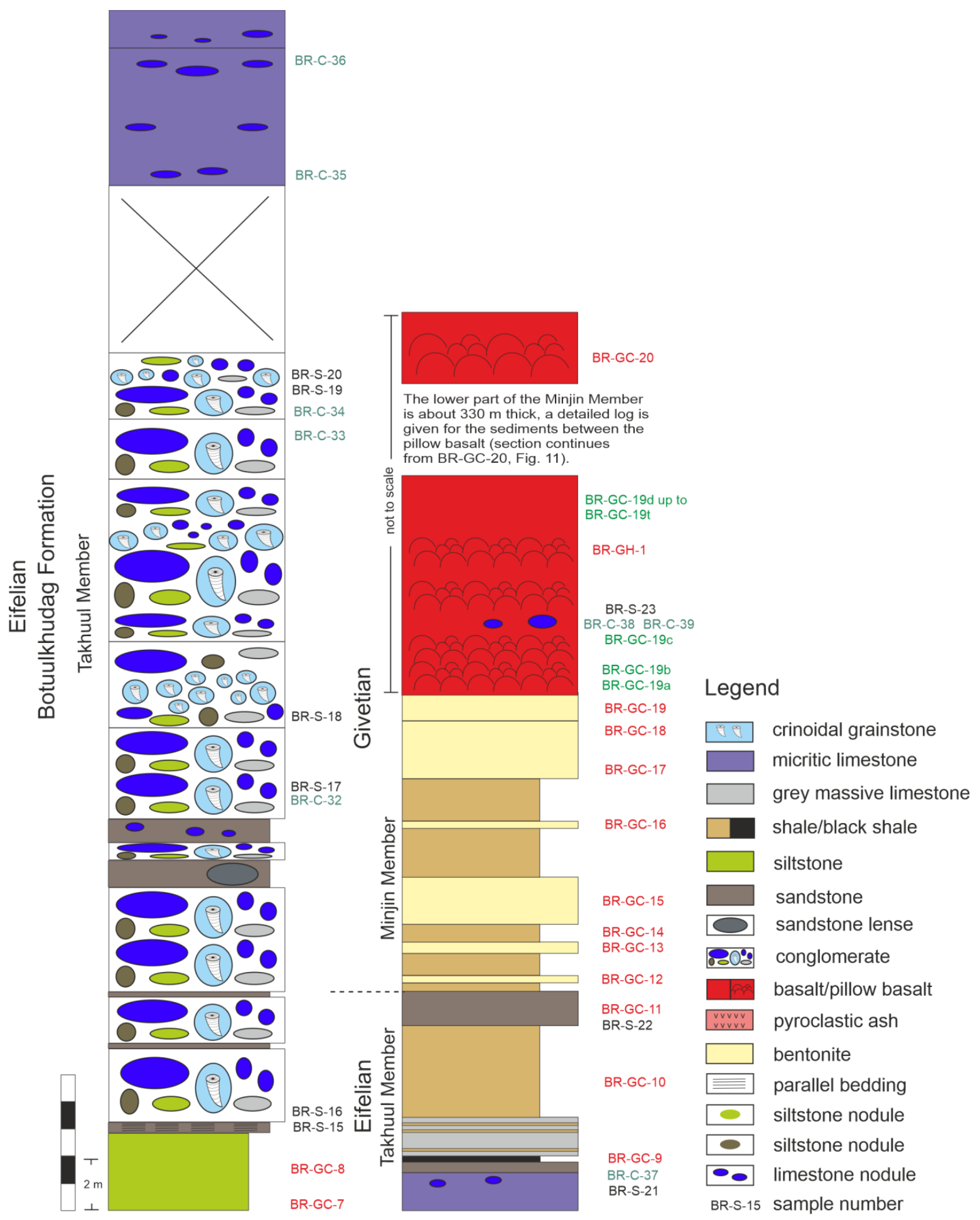

Fig. 8 Lithological log of the Botuulkhudag Formation, Takhuul Member, and the lower part of the Minjin Member

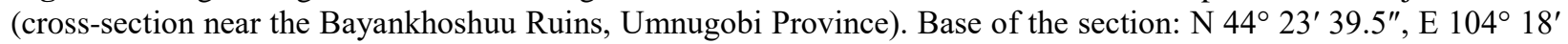
14.2"; end of the section: $\mathrm{N} 44^{\circ} 23^{\prime} 41.0^{\prime \prime}$, E $104^{\circ} 18^{\prime} 13.6^{\prime \prime}$. Note that a detailed lithological log of the section within the basalts is shown in Fig. 11. Sample numbers: "C" = conodont samples, "S" = sedimentology/facies, "GC" = samples for geochemistry. 

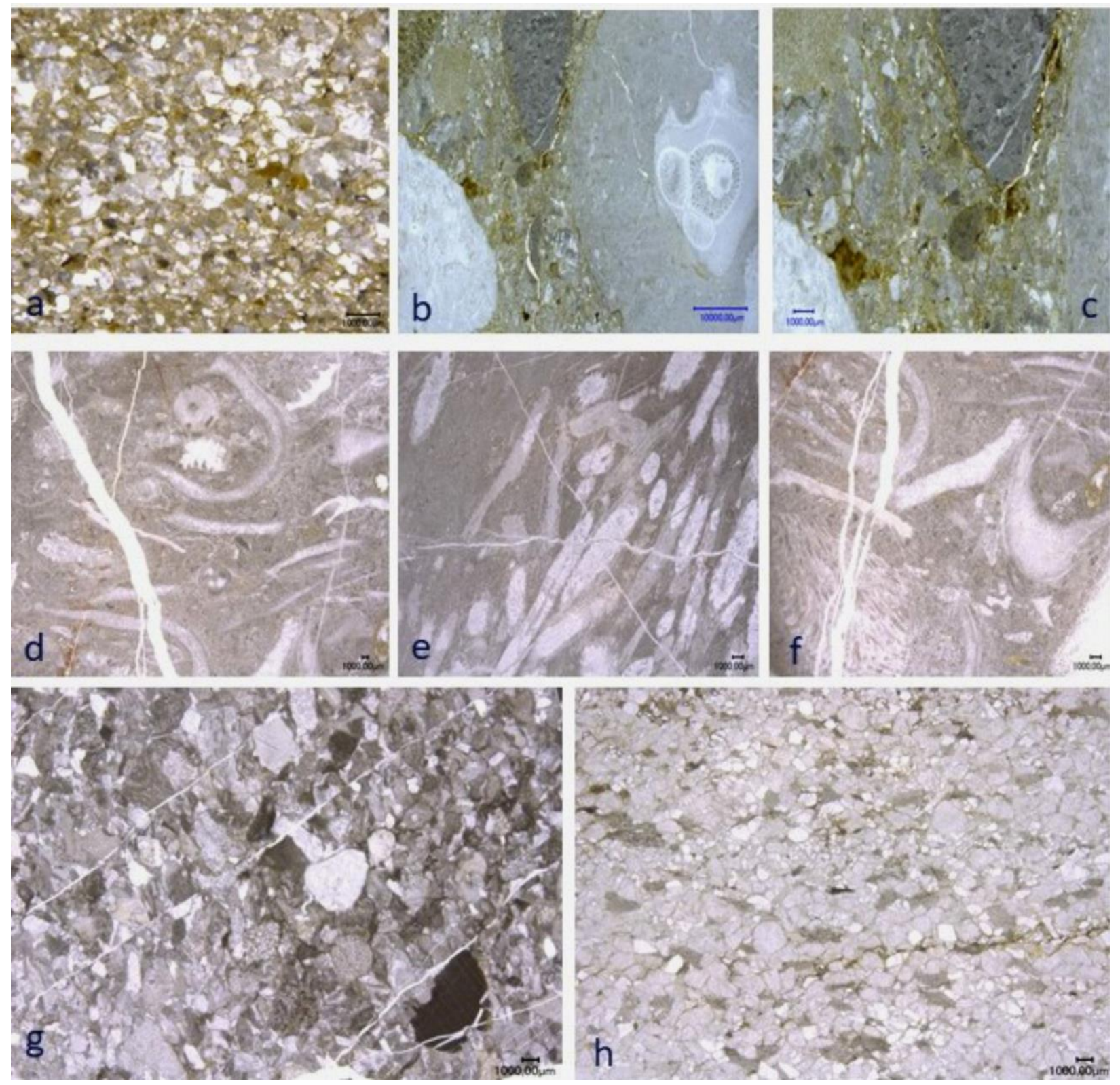

Fig. 9 Microfacies/lithology of the Botuulkhudag Formation, Takhuul Member; a arkosic sandstone at the base of the Takhuul member (sample BR-S-15); b various clasts of the conglomerate; fossiliferous limestone clasts with excellent preserved corals; reworked material with geopedals (sample BR-S-18); c detailed view of the conglomerate matrix showing the sedimentary clasts with sand and smaller-sized particles filling the spaces between them. The largest pebbles are about $10 \mathrm{~mm}$ across (sample BR-S-20); d-f fossiliferous wackestone to floatstone representing the carbonate boulder from the conglomerate (samples BRS-18, BR-S-20); note the diverse fauna such as corals, crinoids, and brachiopod shells; $\mathbf{g}$ calcareous sandstone of the upper part of the Takhuul Member (sample BR-S-21); components are subangular to subrounded and the sediment contains extraclasts (shale); $\mathbf{h}$ moderately sorted thick-bedded sandstone at the top of the Takhuul Member.

chert. Pyroclastic rocks, which can reach a thickness of several meters, provide evidence of strong subaerial volcanism in the Late Devonian. 
Based on field observations and laboratory analysis, radiolarians are found in this part of the section in samples BR-F-3 to BR-F-6 (Fig. 12). The radiolarian assemblage (Fig. 13a-m) is not very diverse and poorly preserved as a result of metamorphism (recrystallization) but points to a Late Devonian age.
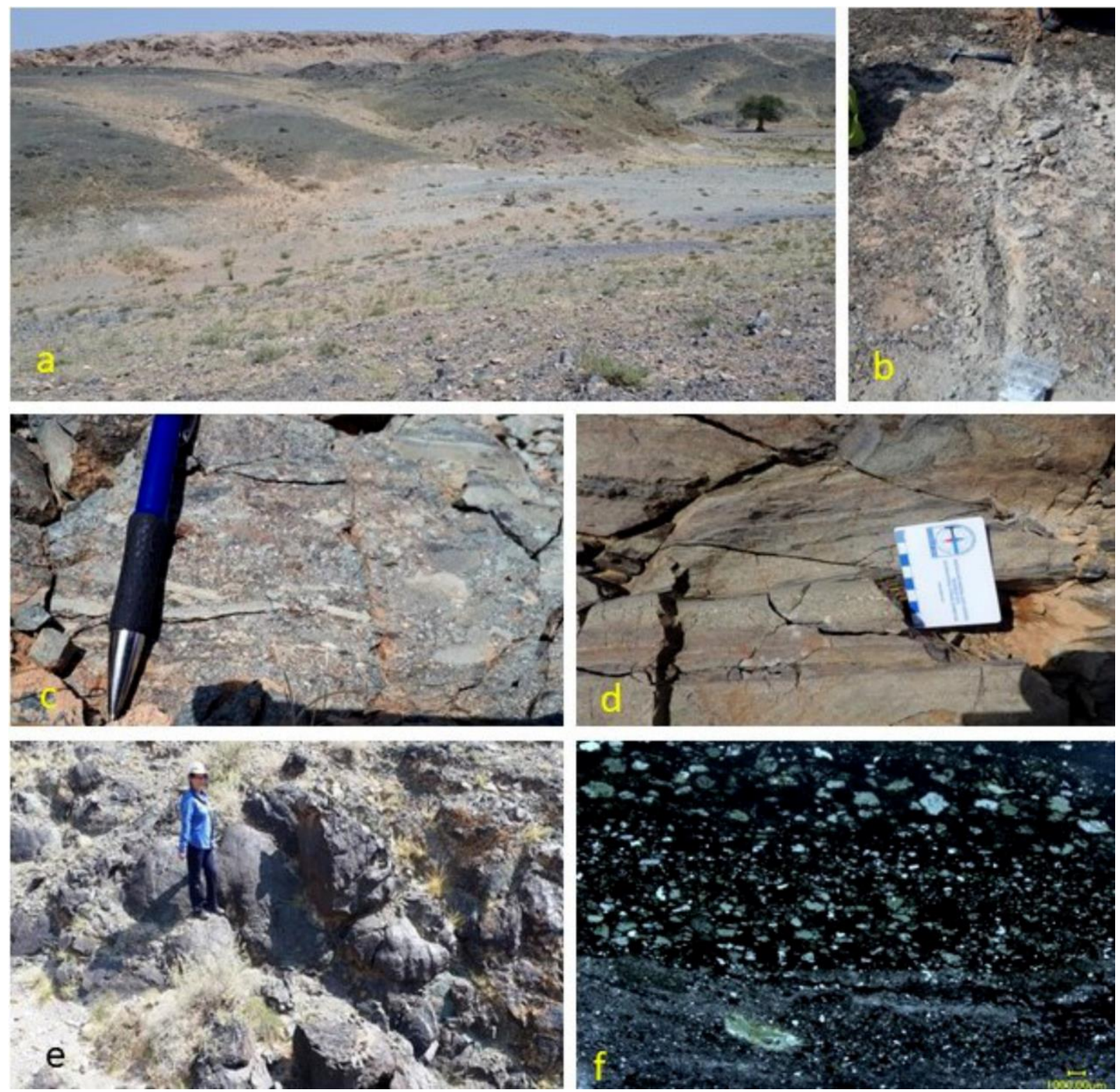

Fig. 10 Field photographs (a-e) showing lithological units and sedimentological features of the Minjin Member, Bayankhoshuu Ruins section; a overview of the micritic limestone (blueish color) shales and bentonite (grayish and whitish rocks) which are covered by basalts (brownish color), view to the North; Botuulkhudag Formation, Minjin Member (cross-section near the Bayankhoshuu Ruins, Umnugobi Province); b detail of thick-bedded bentonite (sample BR-GC 17), Botuulkhudag Formation, Minjin Member (cross-section near the Bayankhoshuu Ruins, Umnugobi Province); c detail of pyroclastic rock (sample BR-GC 40; see Fig. 10), Botuulkhudag Formation, Minjin Member (cross-section near the Bayankhoshuu Ruins) generated by explosive fragmentation of magma and/or previously solid rock during the course of volcanic eruptions; $\mathbf{d}$ detail of pyroclastic rock with inverse gradation (sample BR-S-43; see Fig. 10), Botuulkhudag Formation, Minjin Member (cross-section near the Bayankhoshuu 
Ruins, Umnugobi Province) which exhibits inverse gradation; e large pillows in the upper part of the Minjin Member, Botuulkhudag Formation (cross-section near the Bayankhoshuu Ruins, Umnugobi Province); $f$ thin section of a pyroclastic rock with inverse gradation, Minjin Member (sample BR-S-43; see Fig. 11).

Representatives of the genus Stigmosphaerostylus (not figured herein) found in samples BR-F3 and BR-F-4 are not helpful biostratigraphically as this genus has a long stratigraphical range from the Early through Late Devonian. Trilonche minax (Fig. 131, m; sample BR-F-6) is part of the Trilonche minax assemblage and ranges from the uppermost Givetian to lower Frasnian as reported from the Gamilaroi Terrane in the New England Orogen, Eastern Australia (Aitchison et al. 1999, 2017). In Thailand and Laos, this species is found in Frasnian sections (Thassanapak et al. 2012; Wonganan and Caridroit 2005). However, this species is also known from Givetian as well as from Frasnian and Famennian sections in Russia, China, and the USA (Foreman 1963; Nazarov 1975; Wang et al. 2003a, b). Helenifore robustum (Fig. 13d-k; sample BR-F-3) occurs in late Frasnian worldwide (e.g., Wang et al. 2003a, b). The radiolarian stratigraphy is supported by conodonts found in samples BR-F-4 and sample BR-F-5 (see Figs. 12 and 13). The conodont species Polygnathus angustidiscus (Fig. 13p, q; sample BR-F-4) and Polygnathus pollocki (Fig. 13n, o; sample BR-F-5; Fig. 12) range from the Middle Devonian (Givetian) to the Late Devonian (Frasnian) (e.g., Narkiewicz and Bultynck 2016). Polygnathus pollocki has been reported in many studies from Upper Devonian rocks such as from Poland by Balinski (1979) and Racki (1992) ranging from the transitans to the punctata conodont biozone (late Frasnian to middle Frasnian), and from the Canning Basin, Australia, where this species ranges into the early Famennian (Druce 1976). Along with the radiolarian data, this part (BR-F-3 to BR-F-6) of the Minjin Member suggests a late Frasnian age.

This succession is conformably overlain by the uppermost part of the Minjin Member which is characterized by an alternation of silicified siltstone, chert, and thin-bedded pyroclastic rock (Fig. 11). Unfortunately, we do not have any radiolarian data from this part of the formation. Both samples (BR-F-7 and BRF-8) were barren. However, it seems likely that the Minjin Member ranges into the Famennian as we have found diagnostic conodonts of the Famennian, such as Palmatolepis cf. gracilis gracilis in younger parts of the section (Fig. 12, sample BR-C42; Fig. 15b). This species ranges from the Upper rhomboidea biozone (Klapper and Ziegler 1979) to the ?Upper praesulcata biozone (Ji and Ziegler 1993). According to the revised Late Devonian Conodont Zonation by Spalletta et al. (2017), the species ranges from the Palmatolepis gracilis gracilis biozone to the ?Protognathodus kockeli biozone. That means that the Minjin Member in our section has a stratigraphical range from the Middle Devonian (Givetian) to the Upper Devonian (Late Famennian). This unit is covered by siltstone and two thick bedded layers of pyroclastic rock.

In the next unit, we have found conodonts at the base of the Arynshand Formation. Minjin et al. (2001) suggested that a hiatus occurs around the D/C boundary. From the sedimentological point of view, Upper Devonian rocks in our section are disconformably overlain by Mississippian rock 


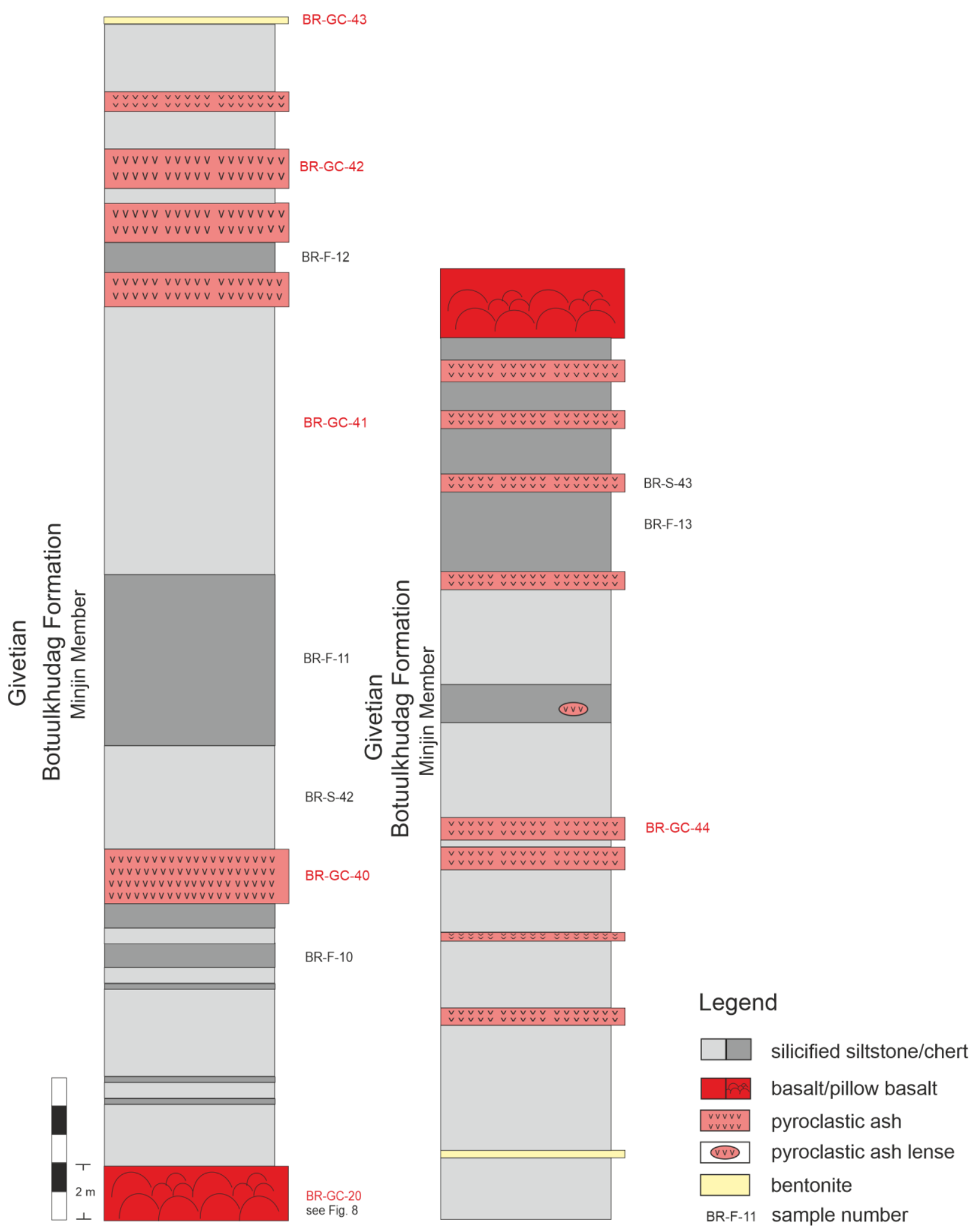

Fig. 11 Lithological log of the Botuulkhudag Formation, Minjin Member (detailed section in between pillow basalts;

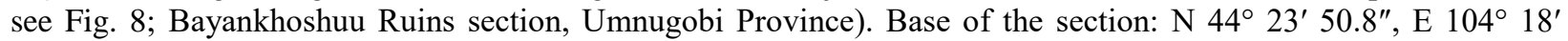

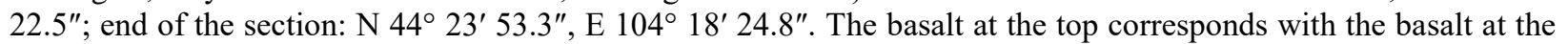
base shown in Fig. 12. Sample numbers: "F" = fauna samples, "S" = sedimentology/facies, "GC" = samples for geochemistry. 


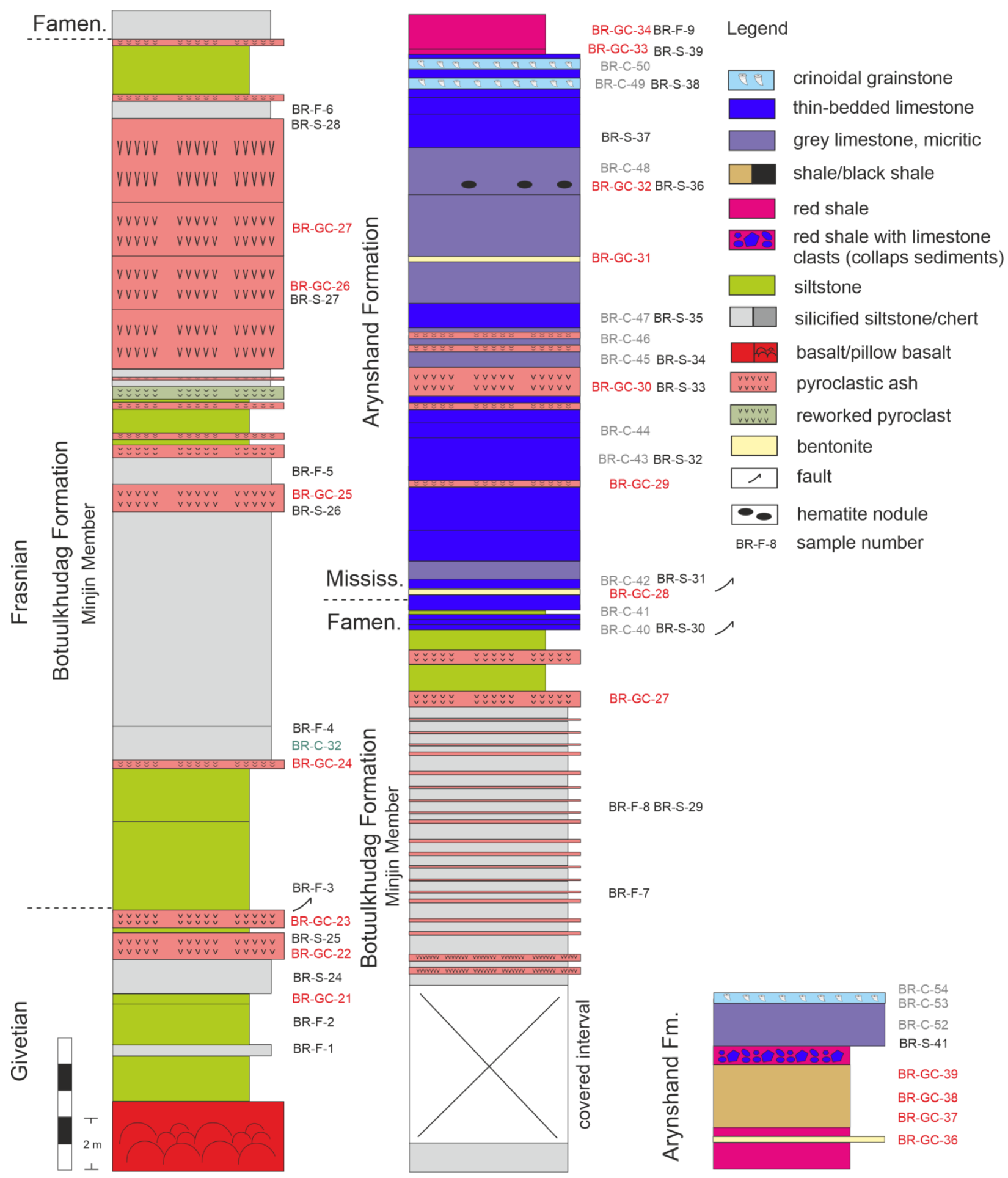

Fig. 12 Lithological log of the Botuulkhudag Formation (Minjin Member) and the Arynshand Formation. Base of

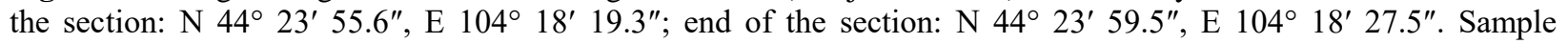
numbers: "C" = conodont samples, "F" = fauna samples, "S" = sedimentology/facies, "GC" = samples for geochemistry. 


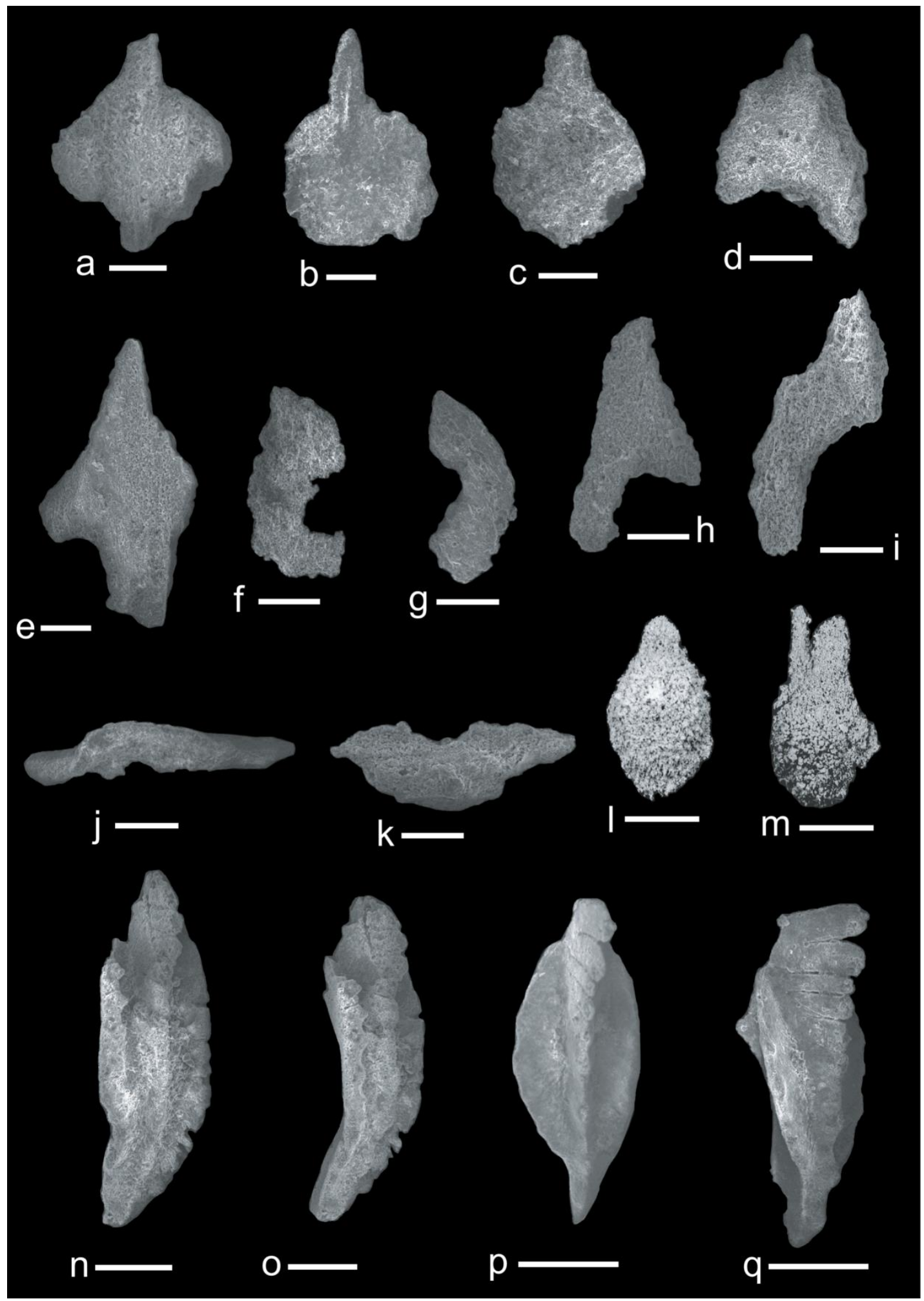

Fig. 13 Radiolarians and conodonts found in the Minjin Member: a, b Trilonche cf. T. davidi (Hinde); $\mathbf{a}=$ sample number BR-F-3; b = sample number BR-F-5; $\mathbf{c}=$ Trilonche sp., sample number BR-F-5; d-k Helenifore $\mathrm{cf}$. $H$. robustum (Boundy-Sanders and Muchey); $\mathbf{d}-\mathbf{i}=$ sample number BR-F-3; $\mathbf{j}-\mathbf{k}=$ sample number BR-F-4; $\mathbf{l}, \mathbf{m}$ Trilonche cf. T. minax (Hinde), sample number BR-F-6; n, o Polygnathus pollocki Druce, sample BR-F-5; p, q Polygnathus angustidiscus Yongquist, sample BR-F-4. Scale bars $=100 \mu \mathrm{m}$. 
(see next section) which seems to be a result of thrusting rather than a hiatus. Evidence of subaerial exposure and/or non-deposition, which is reported from areas close to this section (Wang et al. 2005), seems unlikely based on facies characteristics of Upper Devonian rocks which represent deep-water facies such as siltstone and radiolarian chert (sample BR-S-29, Fig. 13a).

\subsection{Arynshand Formation}

This formation was established by Aleseeva (1993) and is widely distributed in the Mushgai area with a thickness of 150 to $250 \mathrm{~m}$. The Arynshand Formation is primarily composed of limestone, but in contrast to earlier publications (e.g., Ariunchimeg and Nyamsuren 2001; Wang et al. 2005), it also contains bentonites, pyroclastic volcanics, crinoidal grainstone, and red shale in the upper part (Figs. 11 and 14c, d). In earlier publications, this formation was interpreted as ranging from Late Devonian to Early Carboniferous (Minjin et al. 1993). In later publications, Minjin et al. (2001), Wang et al. (2005) and Wang and Minjin (2004) concluded that the lower part of the Arynshand Formation at the Bayankhoshuu Ruins section ranges from the sandbergi biozone to the Lower crenulata biozone and that the D/C boundary was not exposed in the thin-bedded limestone due to a hiatus between the Arynshand Formation and the underlying rocks of the Botuulkhudag Formation (Minjin Member). In the Murugtsug section nearby (about $300 \mathrm{~m}$ west of this section), the Devonian-Carboniferous transition was reported based on the conodonts (Siphonodella praesulcata and Siphonodella sulcata were found). Unfortunately, the conodonts were not illustrated and thus the D/C transition in this area remains questionable. Aristov (1998) reported from the same section even younger conodonts ranging from the duplicata biozone to the Upper crenulata-isosticha biozone (zonation scheme after Sandberg et al. 1978).

The lower part of this formation starts with limestones, thin shale, and a bentonite bed. In the middle part of the Arynshand Formation several layers of pyroclastic rocks and another bentonite occur (Fig. 12). This succession is overlain by grayish, micritic limestone and crinoidal grainstone (sample BR-S-38, Figs. 11 and 14c) at the top. Separating this interval and the massively bedded limestone above, a breccia occurs. Scholle et al. (1993) have shown that timing of solution-breccia formation can be problematic whether the breccias were formed synsedimentary or during late diagenesis. Very early in the diagenetic evolution of sediments, desiccation cracks developed in the host sediment. As a result of incomplete solution collapse, a dense network of fractures is formed (e.g., Assereto and Benelli 1971; Pomoni-Papaioannou and Karakitsios 2002), and owing to progressive evaporite dissolution, an enlargement of the cracks can result to in situ brecciation. The collapse structure in our section can be characterized as a monomict tectonic fault breccia (Fig. 14d-e) which may also lead to subaerial exposure and karst in a later stage. The breccia consists of mainly angular, millimeter- to several decimeter-sized clast-supported and matrix-supported clasts. Strong fracturing concerns the whole rock as well as individual clasts. Microfractures differ in width, orientation, and filling, and the matrix consists of small pieces of rock fragments which are bound together by sparry calcite (Fig. 14d). These features support a fault breccia. 
This succession is overlain by red shale which yields some large boulder of older crinoidal grainstone (Fig. 14e, g). It seems likely that this unit represents paleokarst and subaerial exposures in the early Mississippian (close to the Tournaisian/Visean boundary; see conodont record).
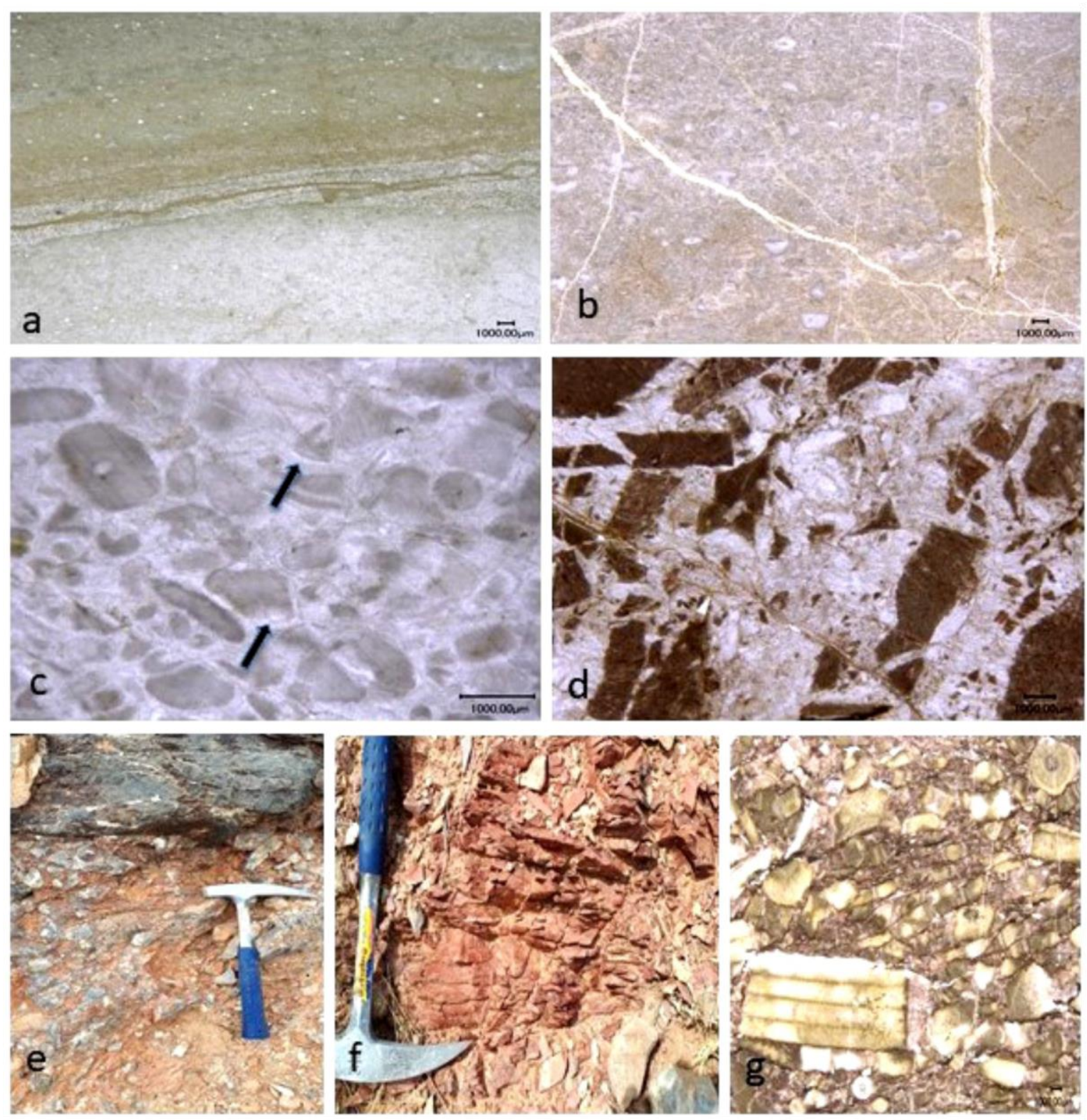

Fig. 14 Microfacies/lithology of the Botuulkhudag Formation, Minjin Member, and examples from the Arynshand Formation: a micritic limestone with radiolarians. In the middle part of the thin section, a thin intercalation of siltstone occurs deposited as distal turbidite or as a result of bottom currents in basinal facies setting (Minjin Member, sample BRS-28); b Wackestone with rare crinoids, base of the Arynshand Formation (Early Mississippian, sample BR-S-31); c moderately sorted crinoid packstone, syntaxial rim cement (arrows) indicate continuous growth of crinoid calcite under burial conditions (sample BR-S-38); $\mathbf{d}$ monomict breccia at the upper part of the Arynshand Formation; some calcite veins postdate brecciation (sample BR-S-39); e Field photograph of limestone breccia with red shales; $\mathbf{f}$ red shales at the top of the Arynshand Formation, photo taken around sample BR-F-9; $\mathbf{g}$ poorly sorted, 
densely packed crinoid packstone which shows strong compaction and pressure solution indicated by stylolitic boundaries between crinoid fragments (sample BR-S-38).

Our biostratigraphic results from recent fieldwork and review of the conodont collection by Wang et al. (2005) differ from the results in earlier publications (see above) and provide a more precise biostratigraphic framework. A formation should be a mappable unit, and thus, the Arynshand Formation starts with the first limestone which lies disconformably upon the Minjin Member (Fig. 12). The first conodont sample BR-C-40 did not yield conodonts, but the following sample BR-C-41 yields Polygnathus cf. longiposticus (Fig. 15c, sample BR-C-41). This species has a stratigraphical range from the ?Bispathodus ultimus biozone to Tournaisian (Spalletta et al. 2017). The next conodonts were found in sample BR-C-42: Palmatolepis cf. gracilis gracilis (Fig. 15b), Polygnathus inornatus (Fig. 15e), and Polygnathus communis cf. renatae (Fig. 15d). Polygnathus cf. gracilis gracilis ranges from the Palmatolepis gracilis gracilis biozone to the ?Protognathodus kockeli biozone (Spalletta et al. 2017), Polygnathus communis cf. renatae ranges from the Bispathodus ultimus biozone to Tournaisian, and Polygnathus inornatus ranges from the Bispathodus costatus biozone to Tournaisian (Spalletta et al. 2017). Thus, this assemblage most probably is late Famennian in age (Lower praesulcata biozone according to the biozonation by Ziegler and Sandberg (1990) or the Bispathodus ultimus biozone published in Spalletta et al. 2017). Sample BR-C-43 (Fig. 15) yields an assemblage including Siphonodella cf. duplicata the name bearing species of the duplicata biozone. Neither Siphonodella sulcata nor Protognathodus species (such as Pr. kuehni or Pr. kockeli) was found which would be helpful to define the D/C boundary. From the sedimentological point of view, there was no evidence of a Hangenberg Crises and related characteristic lithology such as black shales or black limestone (which is not necessarily the case in all D/C sections worldwide and depend on facies, but characteristic lithologies are frequent; Kaiser et al. 2015; Königshof et al. in press), but this part of the section was thrusted and strongly folded. Thus, our interpretation is that the D/C boundary is not exposed in this section due to strong tectonic overprint. Sample BRC-44 yielded Polygnathus cf. tenuiserratus M1 (Fig. 15m) which occurs in the Lower to Upper duplicata biozone (Corradini et al. 2003). The next younger unit was found in sample BR-C-47. Bispathodus stabilis (Fig. 15 p), Polygnathus purus purus (Fig. 15s), some Siphonodellid species, and the index species Siphonodella crenulata correspond to the Lower crenulata biozone.

The youngest part documented in this section by conodonts (sample BR-C-50, Fig. 12) represents the Scaliognathus anchoralis-Doliognathus latus biozone. This biozone is defined by the presence of Scaliognathus anchoralis and Doliognathus latus. The latter one was not found, but two subspecies of Scaliognathus, Scaliognathus anchoralis anchoralis and Scaliognathus anchoralis europensis (Fig. 15q-u), were identified. This unit is covered by red shales with a tectonic breccia at the base suggesting a syntectonic fault breccia, followed by shales and red shales with limestone clasts, which is most likely a result of subaerial exposure around the Tournaisian/Visean boundary. Conodont data suggest that the Arynshand Formation ranges from the Bispathodus ultimus conodont biozone (late Famennian) to the Scaliognathus anchoralis- 
Doliognathus latus biozone (Mississippian, corresponds to the transition of the Tournaisian/Visean boundary in Belgium) in the Bayankhoshuu Ruins section.
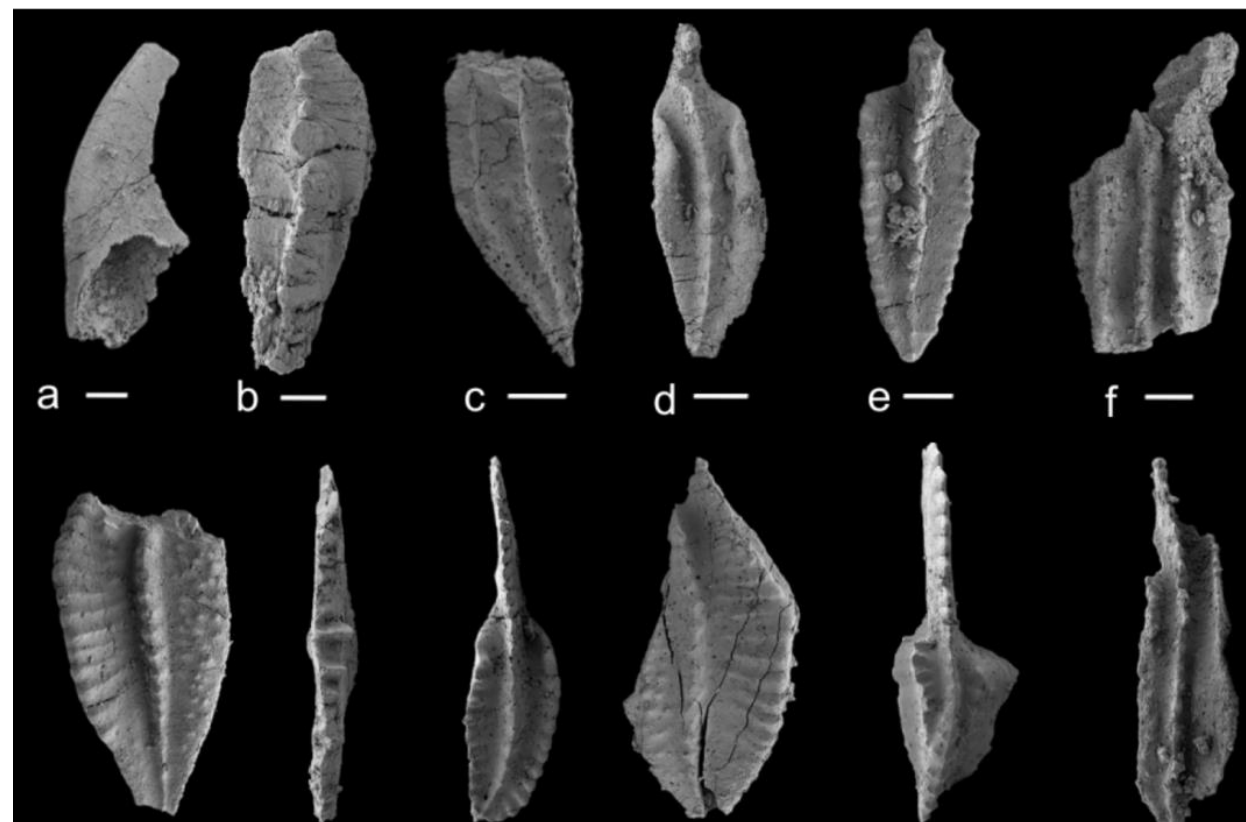

$\mathrm{b}-$

C

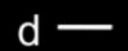

e-

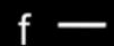

$\mathrm{g}-$
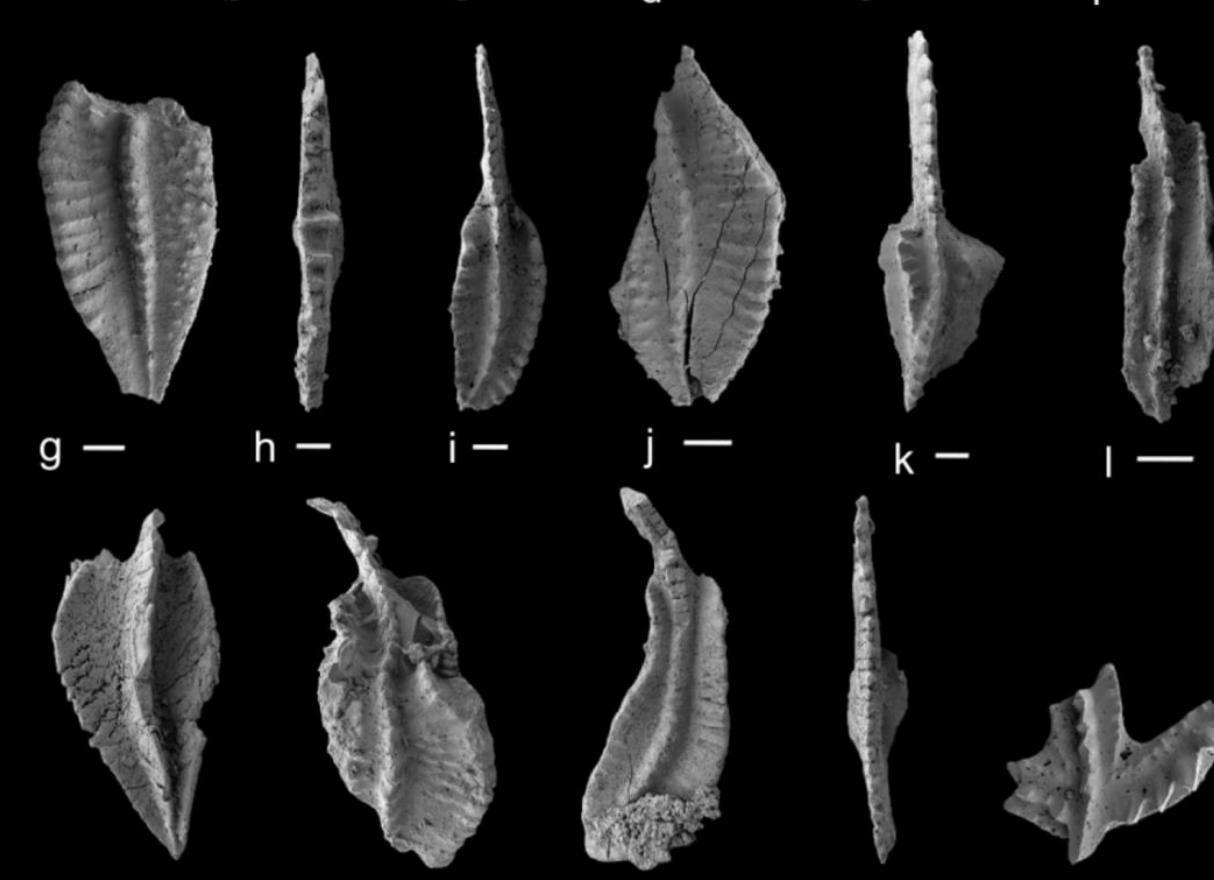

$\mathrm{h}-$
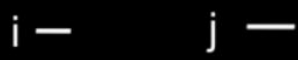

$\mathrm{k}-$
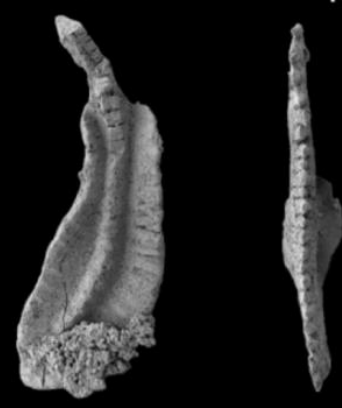

0 -

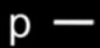

q -
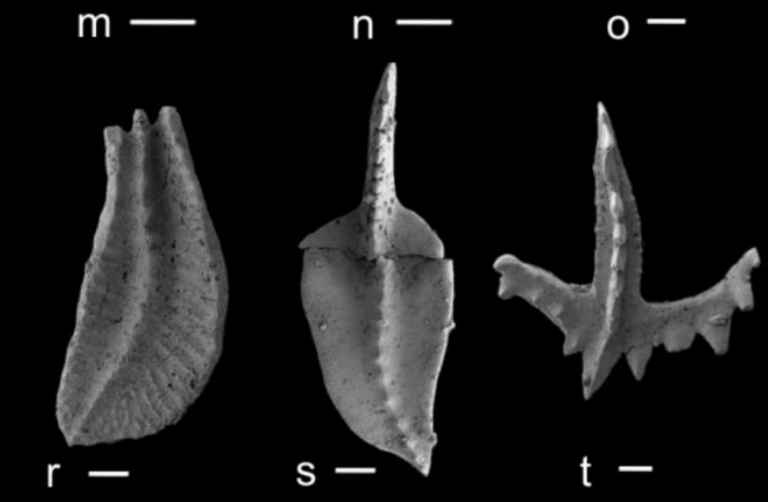

$t-$

$\mathrm{u}$

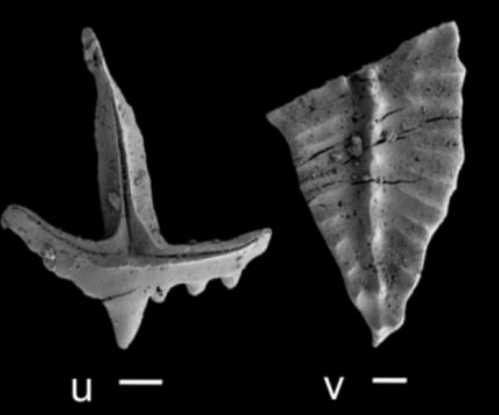

Fig. 15 Conodonts from Ordovician and Devonian/Carboniferous: a Walliserodus cf. amplissimus or Hamarodus sp. b Palmatolepis cf. gracilis gracilis Branson \& Mehl, 1934a incomplete and highly altered species. c Polygnathus cf. longiposticus Barnson \& Mehl 1934a. d Polygnathus communis cf. renatae, Corradini et al. 2003. e Polygnathus inornatus Branson \& Mehl, 1934b. f Siphonodella sp. (cf. duplicata?), g Siphonodella cf. duplicata, h Bispathodus cf. spinulicostatus (Branson 1934). i Polygnathus sp. j Siphonodella cf. duplicata. k Gnathodus pseudosemiglaber Thompson \& Fellows, 1970. I Polygnathus cf. longiposticus. m Polygnathus cf. tenuiserratus M1, Corradini et al. 
2003. n Siphonodella crenulata Cooper 1939. o Siphonodella sp. p Bispathodus stabilis Branson \& Mehl 1934a. q Scaliognathus cf. anchoralis europensis Lane \& Ziegler 1983. r Siphonodella sp. s Polygnathus purus purus Voges 1959. t Scaliognathus anchoralis anchoralis Barnson \& Mehl 1941. u Scaliognathus anchoralis europensis Lane \& Ziegler 1983. v Polygnathus purus purus Voges, 1959. Scale bars $=100 \mu \mathrm{m}$.

\subsection{Tal Formation}

The Tal Formation is composed of siliciclastic rock and limestone. The formation is distributed in the northern part of the region and has a thickness of $500 \mathrm{~m}$. Lithologically, the Tal Formation is subdivided into three parts: the lower part (Shand Member) is characterized by fine-grained clastics, $52 \mathrm{~m}$ in thickness; the middle part (Bayankhoshuu Member) is predominantly composed of carbonates with a thickness of $50 \mathrm{~m}$ yielding badly preserved fossils; and the upper part (Muusukhait Member) is composed of dark-gray, black siltstone, clay slate containing pyrite, and fine-grained sandstone with thin bituminous limestone layers, with an exposed thickness of over $300 \mathrm{~m}$. According to Suetenko et al. (1977), the lower part of this formation has tectonic contacts on both sides whereas Nyamsuren (1998) reported that the contact between the Arynshand Formation and the Tal Formation is conformable, which is shown in the Bayankhoshuu Ruins section. The interpretation by Nyamsuren (1998) is not likely as in the upper part of the Arynshand Formation limestone breccias and red shales occur which point to subaerial exposure rather than a continuous succession. The stratigraphical range of the Tal Formation is unclear. Unfortunately, the three conodont samples which were taken from the Tal Formation on the other side of the mountain ridge did not yield conodonts.

\section{Discussion}

All sections are strongly tectonized at all scales from centimeter to kilometer, and many carbonates are diagenetically altered, but not as severely as the western Mongolian sections of the Baruunhuurai Terrane (Munkhjargal, Königshof, Hartenfels et al. 2021). Thrusting at different scales occurs frequently which may explain the thickness differences of some formations in the Bayankhoshuu Ruins area. Tectonic stress and alteration also occur in conodont samples. Some conodont elements exhibit alteration or surface structures which are caused by hydrothermal fluids. Those samples show "high" CAI values (CAI 6) and recrystallization features at the surface and are not useful to estimate palaeotemperatures but provide information on regional metamorphism and tectonic stress (e.g., Epstein et al. 1977, Königshof 2003).

Overall, terrigenous sediments are not common in the Bayankhoshuu Ruins section, indicating deposition some distance from an emergent hinterland. Two intervals of conglomerates with clasts primarily consisting of older carbonate pebbles to cobbles (and larger) indicate subaerial exposure of the carbonates with formation of high-energy deposits likely close to a coastline. Although many of the cobbles are rounded, cobble size is not consistent with long-distance transport. Conglomerates in the Takhuul Member of the Botuulkhudag Formation have both Silurian and Devonian corals in the cobbles. 
The Bayankhoshuu Ruins section has at least three distinct intervals of carbonate development - Upper Ordovician/Lower Silurian, Lower Devonian, and Lower Carboniferous. The presence of a thick carbonate sequence such as in the Carboniferous requires a palaeogeographic position close to a palaeoequatorial realm. Palaeomagnetic results (Safonova et al. 2017) suggest that the Devonian volcanic arc was near the palaeoequator and drifted $40^{\circ}$ to the north which seems unlikely for the early Mississippian. Crinoidal grainstone is most frequent in the Ordovician and less common in Lower Carboniferous carbonates, but benthic fauna is rare with the exception of corals present in distinct layers, but these are not common.

Two distinct types of volcanic activity are observed in the section. Basalts consistent with back arc spreading are dominant in the Middle to Late Devonian of the Bayankhoshuu Ruins section. The Devonian basalts are very thick. The presence of pillow structures in the Devonian basalts indicates active sea floor extrusion. Pyroclastic rocks and bentonites prove periodic subaerial extrusion and occur preferably in the Middle to Late Devonian and are of small importance in the Mississippian. Prolonged volcanic activity particularly in the Late Devonian is reported from many places around the world and has been suggested to be a driver of ecological collapse at the D/C boundary (e.g., Moreno et al. 1996; Paschall et al. 2019; Racki et al. 2018; Racki 2019). Intercalations of deep-water (radiolarian-rich) siltstone and chert indicate multiple periods of sea floor spreading. The section contains more than 20 bentonite layers, some more than $2 \mathrm{~m}$ thick in the outcrop. The bentonites indicate a more distant, more explosive volcanic source likely associated with subduction rather than back arc development.

The succession from the Minjin Member of the Botuulkhudag Formation to the Arynshand Formation (Figs. 8, 10, and 11) is a potentially important sequence. Conodont data from limestone blocks in the basalt prove a Givetian (Middle Devonian) age to the volcanic rocks (Minjin et al. 2001). Although none of us in the field are experts in igneous petrology, we were able to delineate some textural and compositional changes in the volcanic sequence. The lower part of the basalts is finely crystalline with no evidence of pillows. Pillow structures appear above. Basalts in the Minjin Member represent at least two intervals of extrusion as they are separated by a sedimentary sequence some tens of meters thick. Felsic volcaniclastic units are also found in this part of the sequence (Fig. 10). Basalts in the upper part of the Minjin Member show numerous pillow structures, some very large (Fig. 10e). Color changes suggest changes in composition of the magma although, this remains to be confirmed by lab work. According to Lamb and Badarch (2001), geochemical data from the pillow lava of the Mandalovoo Terrane show that they were erupted in a subduction zone setting. Volcaniclastic successions which can reach a remarkable thickness (Fig. 11) occur in the Late Devonian part of the Botuulkhudag Formation (Minjin Member). The subaerial to marine volcanic activity within the South Gobi Zone suggests the development of an intra-oceanic basin (Lamb and Badarch 1997). The entire section exhibits different subaerial and submarine volcanic phases (Fig. 16).

A more or less complete section from the basalts in the Minjin Member to the limestone of the Arynshand Formation was pieced together in the field. The sedimentary sequence above the 
basalts is composed of a deep-water (below storm wave base) succession-siliceous mudstone, siltstone, or chert (Fig. 16). A remarkable thick succession of about $9 \mathrm{~m}$ thick pyroclastic rocks in the upper part of the Minjin Member suggests explosive subaerial eruptions. Radiolarians which have been found in the overlain siliceous siltstone point to a late Frasnian age. Based on sedimentological characteristics and biostratigraphical data, it seems likely that the Devonian/Carboniferous transition is not exposed in the Bayankhoshuu Ruins section which can be explained by thrusting.

The lower part of the Arynshand Formation is composed of thin-bedded limestone, micrite with some crinoidal grainstone. Separating this interval and the massively bedded limestone above is a small interval of red shale with a breccia at the base suggesting a syntectonic fault breccia. In contrast to paleokarst collapse structure which are characterized by polymict, angular to subrounded clasts, this sediment is composed of angular to subangular, strongly fractured monomict clasts (reddish marls with small shell hash). Thin sections show that calcite veins clearly postdate brecciation.

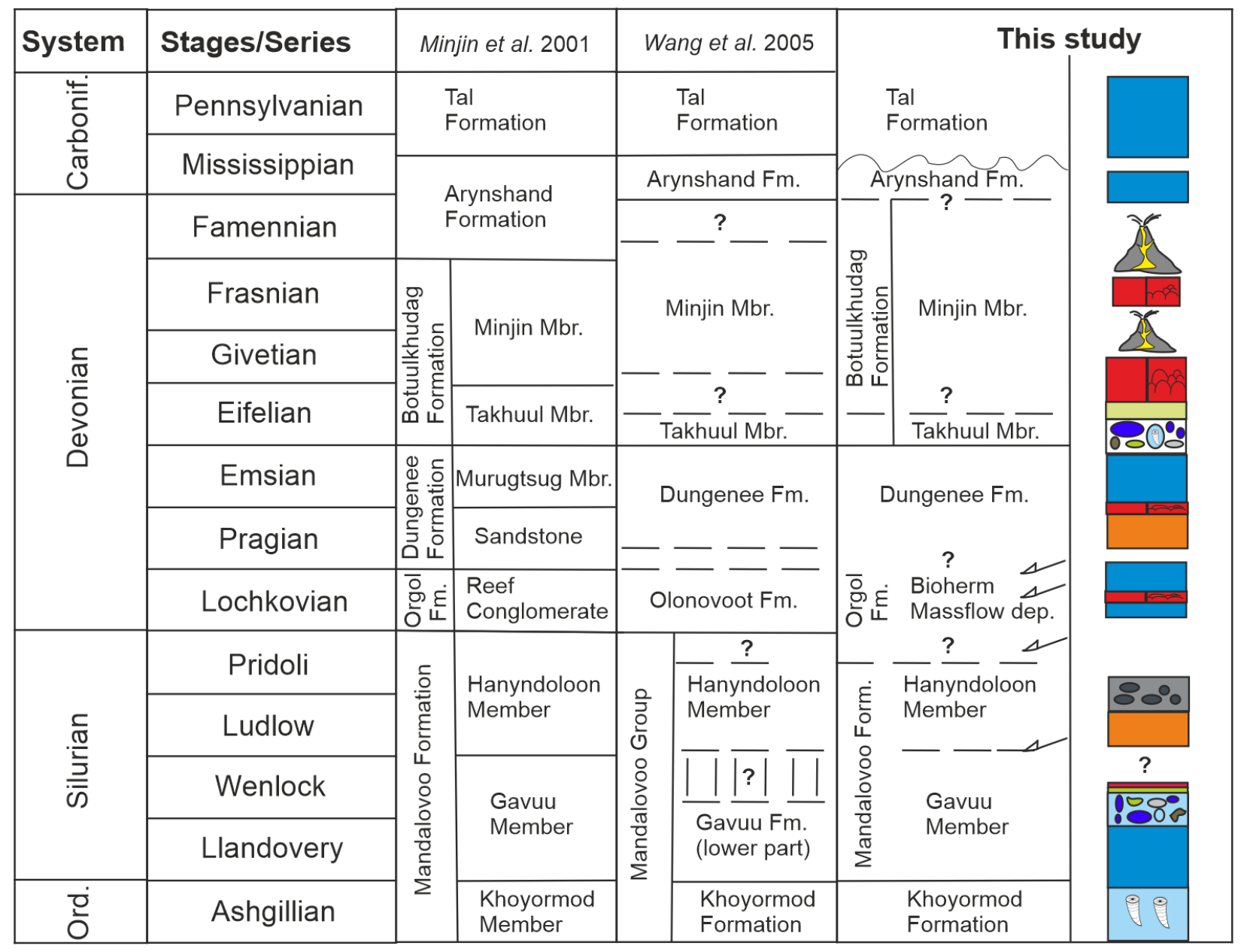

Fig. 16 Stratigraphic chart of formations/members of the Bayankhoshuu Ruins section combined with tectonic and volcanic events (unconformity/hiatus, basalts/pyroclastic deposits) of southern Mongolia, Mandal Ovoo area (Umnugobi Province) based on published data (Minjin et al. 2001; Wang et al. 2003, 2005) and our results. The 
right column shows a composite lithological log of the investigated sections. The succession is mainly composed of pelagic/hemipelagic sediments and exhibits different subaerial and submarine volcanic phases. For more details, see figures and explanations in the text.

The red shales on top of that succession exhibit large rounded blocks of crinoid limestones, and a subaerial exposure/paleokarst seems likely in that case rather than a tectonic breccia. It is probable that subaerial exposure is linked with a remarkable eustatic sea-level drop and/or tectonic processes (terrane collision). The youngest conodonts found in the Arynshand Formation below the fault breccia represent the conodont Scaliognathus anchoralisDoliognathus latus biozone. A drop in sea level during the early Mississippian (corresponds to the latest Tournaisian or the Tournaisian/Visean boundary in Belgium= early Mississippian) which resulted in extensive limestone dissolution and karstification at surface and subsurface levels was described by Schönlaub et al. (1991) from the Carnic Alps. This paleokarst is associated with the unconformity that separates the Devonian to Lower Carboniferous limestone sequences from the overlying flysch deposits of the Hochwipfel Formation. In terms of the currently used conodont zonation, this event occurred during the Scaliognathus anchoralisDoliognathus latus biozone.

Interestingly, the paleokarst observed in this study coincided with a regressive cycle reported from the Madison Limestone in North America. The Madison Limestone represents a secondorder super sequence that internally consisted of six third-order sequences (Westphal et al. 2004; Katz et al. 2007; Oehlert et al. 2019). The beginning of the second-order regressive cycle is roughly correlated with the base of the Scaliognathus anchoralis-Doliognathus latus biozone, but there is no evidence of exposure horizon or karstic surfaces which is similar to coeval sections in Belgium (Hance et al. 2002). Thus, it seems plausible that karstification observed in the early Mississippian of the Bayankhoshuu Ruins section represents a local event. By the end of Tournaisian time, the eastern margin of the Russian Platform experienced uplift, exposure, and increased volcanism associated with collision of volcanic arcs and Uralian microcontinents to the east (Kirikov 1988; Ulmishek 1988). Guy et al. (2014) described various sections in the south Gobi Zones in southern Mongolia such as a section from the Noyon Uul syncline which is in the west of our study area. In their summary of lithostratigraphic units, they have shown an unconformity/hiatus which occurs in the Early Carboniferous, but details on stratigraphy are not given. So, it seems questionable where this event can be linked with the unconformity observed in the Bayankhoshuu Ruins section.

Lower in the section (Siphonodella isosticha-Upper Siphonodella crenulata biozone to Lower Gnathodus typicus biozone), one of the largest 813 Ccarb excursions in the Phanerozoic in the early Mississippian were reported from various regions (e.g., Bruckschen et al. 1999; Saltzmann et al. 2004; Oehlert et al. 2019). As this critical period is also exposed in the studied section (see conodont record above), geochemical studies are necessary to prove evidence of this important $\delta 13$ Ccarb excursion in the early Mississippian of the Bayankhoshuu Ruins section. 


\section{Conclusion}

- Although many more conodont samples are necessary in order to provide a better biostratigraphic record, this report provides important sedimentological and stratigraphical descriptions from the Bayankhoshuu Ruins section (Mushgai area, southern Mongolian Gobi). We could improve the stratigraphy of some formations such as the Khoyormod Formation, the Botuulkhudag Formation (particularly the Minjin Member), and the Arynshand Formation.

- The Bayankhoshuu Ruins section is characterized by strongly thrusted and folded sequences which contain relatively scarce fossils except some distinct horizons. However, based on this study, the Bayankhoshuu Ruins section ranges from the Late Ordovician (Khoyormod Formation) to the early Mississippian (Arynshand Formation).

- Due to the general rareness of fossils, poor preservation, and strong tectonic overprint, it was not possible to pinpoint Palaeozoic event layers, but we provide more detailed information on the placement of the succession within the Palaeozoic Terrane scheme for Mongolia.

- The Bayankhoshuu Ruins section exposes mainly deepwater (hemipelagic and pelagic) deposits composed of limestones, siltstones, and cherts; shallow-water sediments are less frequent.

- Red shales occur in the lower part of the early Mississippian Arynhand Formation suggesting subaerial exposure/paleokarst which corresponds to the latest Tournaisian or the Tournaisian/Visean boundary in Belgium. An equivalent of this unconformity was described from the Carnic Alps.

- The marine sedimentary succession is interjected by volcanic rocks - basaltic lava of Silurian and Middle Devonian age and volcaniclastic bentonite and tuff in the Middle to Late Devonian and Mississippian which can reach a remarkable thickness. Deposits of the Bayankhoshuu Ruins section suggest an island arc setting. Overall, deposition likely occurred on either the Mandalovoo or Gurvansayhan Terrane.

- Late Devonian and Mississippian rocks of the Bayankhoshuu Ruins section are not comparable with the shallow-water Hushoot Shiveetiin gol section (Baruunhuurai Terrane) in western Mongolia where a reasonably abundant and diverse macrofauna has been described (Munkhjargal, Königshof, Hartenfels et al. 2021; Crônier et al. 2021; Nazik et al. 2021; Waters et al. 2021), but facies settings of both sections are characterized by very strong volcanic activity, particularly in the Late Devonian.

\section{Acknowledgements}

Fieldwork in the southern Gobi in Mongolia can be difficult. We acknowledge and appreciate the hard work of our support team, drivers Damdinjamts Gonchigdorj and Bayarjargal Bazarragchaa and cook Baasansuren Gonchigdorj, for making the fieldwork a success. The management of the Olon Ovoot gold mine provided housing during our time in the field. We also acknowledge Byambajargal Bazarragchaa for the use of his Ford SVT Raptor as a field vehicle. Jana Anger 
provided technical assistance in field processing selected samples of conodonts during the fieldwork. We thank Clive Burrett (Mahasarakham University, Mahasarakham, Thailand) and Uyanga Bold (Mongolian University of Science and Technology, Ulaanbaatar, Mongolia) for their helpful comments and suggestions.

\section{Funding}

Open Access funding enabled and organized by Project DEAL. A. Munkhjargal received funding from the German Academic Exchange Service (DAAD, Research Grant - Doctoral Programme in Germany, September 01, 2018, to September 01, 2021; 57381412), P. Königshof has received funding from Deutsche Forschungsgemeinschaft (DFG KO-1622/19-1). This is a contribution to IUGS/UNESCO Project IGCP 652 ("Reading geologic time in sedimentary rocks”).

Compliance with ethical standards: The authors declare that they have no conflict of interest.

\section{References}

Alekseeva, R.E. (1993). Devonian biostratigraphy of Mongolia. Joint Soviet-Mongolian Paleontological Expedition, 44, 33-34 [In Russian].

Aitchison, J.C., Davis, A.M., Stratford, J.M.C., \& Spiller, F.C.P. (1999). Lower and Middle Devonian radiolarian biozonation of the Gamilaroi terrane New England Orogen, eastern Australia. Micropaleontology, 45, 138-162. https://doi.org/10.2307/1486110.

Aitchison, J.C., Suzuki, N., Caridroit, M., Danelian, T., \& Noble, P. (2017). Paleozoic radiolarian biostratigraphy. Geodiversitas, 39(3), 503-531. https://doi.org/10.5252/g2017n3a5.

Aristov, V.A. (1998). Fossil assemblage from shallow-water Devonian of Eurasia (European Russian, Mongolia). Stratigraphy and Geological Correlation, 6(5), 102-116.

Ariunchimeg, Ya., \& Nyamsuren, G. (2001). Upper Famennian and Lower Carboniferous stratigraphy in Mandalovoo and Shin Jinst areas, Mongolia. Transaction Mongolian Science and Technology Geology, 2-3, 24-34.

Assereto, R., \& Benell, F. (1971). Sedimentology of the pre-Cenomanian Formations of the Jebel Gharian, Libya. In Symposium on the geology of Libya (pp. 39-84). Faculty of Science, University of Libya.

Badarch, G., Cunningham, W.D., \& Windley, B.F. (2002). A new subdivision for Mongolia: implications for Phanerozoic crustal growth in Central Asia. Journal of Asian Earth Sciences, 21, 87-110.

Balinski, A. (1979). Brachiopods and conodonts from the Frasnian of the Debnik anticline, southern Poland. Palaeontologica Polonica, 39, 3-95. 
Barrick, J.E. (1997). Wenlock (Silurian) depositional sequences, eustatic events, and biotic change on the southern shelf of North America. In Paleozoic sequence stratigraphy, biostratigraphy, and biogeography, studies in honor of J. Granville ("Jess") Johnson. Eds. G. Klapper, M.A. Murphy, \& J.A. Talent, Geological Society of America, 321, 47-65.

Branson, E.G. (1934). Conodonts from the Hannibal Formation of Missouri. Missouri University Studies, 8, 301-343.

Branson, E.B., \& Mehl, M.G. (1934a). Conodonts from the Grassy Creek shale of Missouri. Missouri University Studies, 8, 171-259.

Bruckschen, P., Oesemann, S., \& Veizer, J. (1999). Isotope stratigraphy of the European Carboniferous: proxy signals for ocean chemistry, climate and tectonics. Chemical Geology, 161, 127-163.

Buslov, M.M., Safonova, I., Watanabe, T., Obut, O.T., Fujiwara, Y., Iwata, K., Semakov, N.N., Sugai, Y., Smirnova, L.V., \& Kazansky, Y. (2001). Evolution of the Paleo-Asian Ocean (AltaiSayan Region, Central Asia) and collision of possible Gondwana-derived terranes with the southern marginal part of the Siberian continent. Geosciences Journal, 5(3), 203-224. https://doi.org/10.1007/BF02910304.

Chlupác, I., \& Kukal, Z. (1986). Reflection of possible global Devonian events in the Barrandian area, C.S.S.R. In O.Walliser (Ed.), Global bio-events, Lecture Notes in Earth Science, 8, 169179.

Cooper, C.L. (1939). Conodonts from a Bushberg-Hannibal horizon in Oklahoma. Journal of Paleontology, 13, 379-422.

Corradini, C., Barca, S., \& Spalletta, C. (2003). Late Devonian-Early Carboniferous conodonts from the "Clymeniae limestones" of SE Sardinia (Italy). Courier Forschungsinstitut Senckenberg, 245, 227-253.

Corriga, M.G., Corradini, C., \& Ferretti, A. (2009). Silurian conodonts from Sardinia: an overview. Rediconti della Società Paleontologica Italiana, 3(1), 95-107.

Crônier, C., Ariuntogos, M., Königshof, P., Waters, J.A., \& Carmichael, S.K. (2021). Late Devonian (Famennian) phacopid trilobites from western Mongolia. Palaeobiodiversity and Palaeoenvironments, 101(3) https://doi.org/10.1007/s12549-020-00449-w.

Dobretsov, N.L., Berzin, N.A., Buslov, M.M., \& Ermakov, V.D. (1995). General aspects of the Altai region interrelationships between its basement pattern and neotectonic structural development. Russian Geology and Geophysics, 36(10), 3-15.

Donskaya, T.V., Gladkochub, D.P., \& Mazukabzov, A.M. (2013). Late Paleozoic-Mesozoic subduction-related magmatism at the southern margin of the Siberian continent and the 150 
million-year history of the Mongol-Okhotsk Ocean. Journal of Asian Earth Sciences, 62, 79-97. https://doi.org/10.1016/j.jseaes.2012.07.023.

Druce, E.C. (1976). Conodont biostratigraphy of the Upper Devonian reef complexes of the Canning Basin, western Australia. Australian Bureau of Resources, Geology and Geophysics, Bulletin, 158, 1-303.

Epstein, A.G., Epstein, J.B., \& Harris, L.D. (1977). Conodont colour alteration - an index to organic metamorphism. Geological Survey of America, Professional Paper, 995, 1-27.

Ferretti, A., \& Serpagli, E. (1999). Late Ordovician conodont faunas from southern Sardinia, Italy: biostratigraphic and paleogeographic implications. Bollettino della Societa Paleontologica Italiana, 37(2), 215-236.

Flügel, E. (2004). Microfacies of carbonate rocks. Berlin: Springer. Folk, R.L. (1954). The distinction between grain size and mineral composition in sedimentary-rock nomenclature. Journal of Geology, 62(4), 344-359. https://doi.org/10.1086/626171.

Foreman, H.P. (1963).Upper Devonian Radiolaria fromtheHuron member of the Ohio shale. Micropaleontology, 9, 267-304.

Guy, A., Schulmann, K., Clauer, N., Hasalova, P., Seltmann, R., Armstrong, R., Lexa, O., \& Benedicto, A. (2014). Late Paleozoic-Mesozoic tectonic evolution of the Trans-Altai and South Gobi Zones in southern Mongolia based on structural and geochronological data. Gondwana Research, 25(1), 309-337. https://doi.org/10.1016/j.gr.2013.03.014.

Hance, P.L., Devuyst, F.-X., \& Poty, E. (2002). Sequence stratigraphy of the Belgian Lower Carboniferous-tentative correlation with the British Isles. In L.V. Hills, C.M. Henderson, \& E.W. Bamber, (Eds.), Carboniferous and Permian of the world. Memoir Canadian Society of Petroleum Geologist, 19, 41-51.

Hartenfels, S. (2011). Die globalen Annulata-Events und die Dasberg-Krise (Famennium, Oberdevon) in Europa und Nord-Afrika - hochauflösende Conodonten-Stratigraphie, KarbonatMikrofazies, Paläoökologie und Paläodiversität. Münsterische Forschungen zur Geologie und Paläontologie, 105, 17-527.

Helo, C., Hegner, E., Kröner, A., Badarch, G., Tomurtogoo, O., Windley, B.F., \& Dulski, P. (2006). Geochemical signature of Paleozoic accretionary complexes of the Central Asian Orogenic Belt in South Mongolia: constraints on arc environments and crustal growth. Chemical Geology, 227(2006), 236-257. https://doi.org/10.1016/j.chemgeo.2005.10.003.

Jeppson, L., \& Anehus, R. (1995). A buffered formic acid technique for conodont extraction. Journal of Paleontology, 69(4), 790-794. 
Ji, Q., \& Ziegler, W. (1993). The Lali section: an excellent reference section for Late Devonian in south China. Courier Forschungsinstitut Senckenberg, 157, 1-183.

Johnson, M.E. (1996). Stable cratonic sequences and a standard for Silurian eustasy. In Special Paper 306, Paleozoic sequence stratigraphy; views from the North American Craton. https://doi.org/10.1130/0-8137-2306-X.203.

Johnson, M.E. (2006). Relationship of Silurian sea-level fluctuations to oceanic episodes and events. GFF, 128, 115-121. https://doi.org/10.1080/11035890601282115.

Johnson, J.G., \& Sandberg, C.A. (1989). Devonian eustatic events in the Western United States and their biostratigraphic responses. In A.F. McMillan Embry, \& D.J. Glass, (Eds.), Devonian of the World. Canadian Society of Petroleum Geologists Memoir, 14(3), 171-179.

Johnson, J.G., Klapper, G., \& Sandberg, C.A. (1985). Devonian eustatic fluctuations in Euramerica. Geological Society of America Bulletin, 96, 567-587.

Kaiser, S.I., Aretz, M., \& Becker, R.T. (2015). The global Hangenberg Crisis (DevonianCarboniferous transition): review of a first-order mass extinction. In R.T. Becker, P. Königshof, \& C.E. Brett, (Eds.), Devonian Climate, Sea Level and Evolutionary Events. Geological Society, Special Publication, 423, 387-437. https://doi.org/10.1144/SP423.9.

Katz, D.A., Buoniconti, M.R., Montanez, I.P., Swart, P.K., Eberli, G.P., \& Smith, L.B. (2007). Timing and local perturbations to the carbon pool in the lower Mississippian Madison Limestone, Montana and Wyoming. Palaeogeography, Palaeoclimatology, Palaeoecology, 256, 231-253.

Kirikov, V.P. (1988). Devonian period in evolution of the Russian Platform. In N.J. McMillan, A.F. Embry, \& D.J. Glass, (Eds.), Devonian of the world, volume I: Regional syntheses. Canadian Society of Petroleum Geologist, Memoir, 14, 513-525.

Klapper, G., \& Murphy, M.A. (1975). Silurian-Lower Devonian conodont sequence in the Roberts Mountains Formation of central Nevada. Geological Sciences, 111, 1-62.

Klapper, G., \& Ziegler, W. (1979). Devonian conodont biostratigraphy. In M.R. House, C.T. Scrutton, \& M.G. Bassett, (Eds.), The Devonian system. Palaeontology 23, 199-224.

Königshof, P. (2003). Conodont deformation patterns and textural alteration in Paleozoic conodonts: Examples from Germany and France. Senckenbergiana Lethaea, 83(1/2), 149-156.

Königshof, P., Bahrami, A., \& Kaiser, S.I. (2021). Devonian-Carboniferous boundary sections in Iran. In M. Aretz, \& C. Corradini, (Eds.), Global review of the Devonian-Carboniferous boundary. Palaeobiodiversity and Palaeoenvironments, 101(2), 613-632. https://doi.org/10.1007/s12549-020-00438-z. 
Kröner, A., Kovach, V., Belousova, E., Hegner, E., Armstrong, R., Dolgopolova, A., Seltmann, R., Alexeiev, D.V., Hoffmann, J.E., Wong, J., Sun, M., Cai, K., Wang, T., Tong, Y., \& Wilde, S.A. (2014). Reassessment of continental growth during the accretionary history of the Central Asian Orogenic Belt. Gondwana Research, 25, 103-125.

Lamb, M.A., \& Badarch, G. (1997). Paleozoic sedimentary basins and volcanic arc systems of southern Mongolia: New stratigraphic and sedimentological constrains. International Geology Review, 39, 542-576.

Lamb, M.A., \& Badarch, G. (2001). Paleozoic sedimentary basins and volcanic arc systems of southern Mongolia: New geochemical and petrographic constraints. In M.S. Hendrix, \& G.A. David, (Eds.), Paleozoic and Mesozoic Tectonic Evolution of Central and Eastern Asia: From Continental Assembly to Intracontinental Deformation. Geological Society of America, Memoir, 194, 117-149.

Lane, H.R., \& Ziegler, W. (1983). Taxonomy and phylogeny of Scaliognathus Branson \& Mehl, 1941 (Conodonta, Lower Carboniferous). Senckenbergiana Lethaea, 64(199-2), 25.

Lane, H.R., Sandberg, C., \& Ziegler, W. (1980). Taxonomy and phylogeny of some Lower carboniferous conodonts and preliminary standard post - Siphonodella zonation. Geologica and Palaeontologica, 14, 117-164.

Loydell, D.K., Männik, P., \& Nestor, V. (2003). Integrated biostratigraphy of the Silurian of the Aizpute-41 core, Latvia. Geological Magazine, 147, 253-280. https://doi.org/10.1017/S0016756802007264.

Minjin, C., Badarch, G., \& Tungalag, F. (1993). Stratigraphy of the Shine Jinst Paleozoic deposits. Mongolian Technical University. Scientific Transactions, 3(18), 3-19 [In Mongolian].

Minjin, Ch., \& Tumenbayar, B. (2001). The guidebook, abstract \& Ordovician Silurian correlation chart for the joint field meeting of IGCP 410 and IGCP 421.

Minjin, C., Sersmaa, G., Ariunchimeg, Ya., Gereltsetseg, L., Undarya, J., Tumenbayar, B., \& Bolortsetseg, M. (2001). The guide book, abstract and Ordovician - Silurian correlation chart for the joint field meeting of IGCP 410 and IGCP 421 in Mongolia. Part II. Mongolian field guide, pp. 12-90.

Moreno, C., Sierra, S., \& Saez, R. (1996). Evidence for catastrophism at the FamennianDinantian boundary in the Iberian Pyrite Belt. Geological Society London Special Publications, 107(1), 153-162. https://doi.org/10.1144/GSL.SP.1996.107.01.12.

Munkhjargal, A., Königshof, P., Hartenfels, S., Jansen, U., Nazik, A., Carmichael, S.K., Waters, J.A., Sersmaa, G., Crônier, C., Ariunchimeg, Ya., Paschall, O., \& Dombrowski, A. (2021). The Hushoot Shiveetiin gol section (Baruunhuurai Terrane): Sedimentology and facies from a Late 
Devonian island arc setting. Palaeobiodiversity and Palaeoenvironments, 101(3). https://doi.org/10.1007/s12549-020-00445-0.

Murphy, M.A., Valenzuela-Rios, J.I., \& Carls, P. (2004). On classification of Pridoli (Silurian)Lochkovian (Devonian) Spathognathodontidae (conodonts). University of California, Riverside Campus Museum Contribution, 6, 1-25.

Narkiewicz, K., \& Bultynck, P. (2016). Taxonomy and biostratigraphic significance of Icriodus orri Klapper and Barrick and related Middle Devonian conodont species. Journal of Paleontology, 90(6), 1-16. https://doi.org/10.1017/jpa.2016.41.

Nazarov, B.B. (1975). Albaillellidea i Paleoscenidiidae iz verkhnedevonskikh otlozhoniy yuzhnogo urala. Trudy VSEGEI n. s., 226, 41-47 [In Russian].

Nazik, A., Königshof, P., Ariuntogos, M., Waters, J.A., \& Carmichael, S.K. (2021). Late Devonian ostracods from the Late Devonian Hushoot Shiveetiin gol section (Baruunhuurai Terrane, western Mongolia) and their palaeoenvironmental implication and palaeobiogeographic relationship. Palaeobiodiversity and Palaeoenvironments, 101(3). https://doi.org/10.1007/s12549-020-00446-z.

Nestor, V., Einasto, R., \& Loydell, D.K. (2002). Chitinozoan biostratigraphy and lithological characteristics of the Lower and Upper Visby boundary beds in the Ireviken 3 section, Northwest Gotland. Proceedings of the Estonian Academy of Sciences Geology, 51, 215-226.

Nyamsuren, G. (1998). New formation in South Mongolia. Mongolian Geoscientist, 9, 1-50.

Oehlert, A.M., Swart, K.P., Eberli, G.P., Evans, S., \& Frank, T.D. (2019). Multi-proxy constraints on the significance of covariant $\delta 13 \mathrm{C}$ values in carbonate and organic carbon during early Mississippian. Sedimentology, 66, 241-261.

Paschall, O.C., Carmichael, S.K., Königshof, P., Waters, J.A., Ta, P.H., Komatsu, T., \& Dombrowski, A. (2019). The Hangenberg event in Vietnam: Sustained ocean anoxia with a volcanic trigger? Global and Planetary Change, 175, 64-81. https://doi.org/10.1016/j.gloplacha.2019.01.021.

Pettijohn, F.J., Potter, P.E., \& Siever, R. (1973). Sand and sandstone (p. 617). Berlin: SpringerVerlag.

Pomoni-Papaioannou, F., \& Karakitsios, V. (2002). Facies analysis of the Trypali carbonate unit (Upper Triassic) in Central-Western Crete (Greece): An evaporite formation transformed into solutioncollapse breccias. Sedimentology, 49, 1113-1132.

Racki, G. (1992). Evolution of the bank to reef complex in the Devonian of the Holy Cross Mountains. Acta Palaeontologica Polonica, 37(2/4), 87-182. 
Racki, G. (2019). Volcanism as a prime cause of mass extinctions: Retrospectives and perspectives. In T. Adatte, D.P.G. Bond, \& G. Keller, (Eds.), Mass extinctions, volcanism, and impacts: New developments. Geological Society of America Special Paper, 544. https://doi.org/10.1130/2019.2544(01.

Racki, G., Rakociński, M., \& Marynowski, L. (2018). Anomalous Upper Devonian mercury enrichments: Comparison of inductively coupled plasma-mass spectrometry (ICPMS) and AAS analytical data. Geology Quarterly, 62(3), 487-495. https://doi.org/10.7306/gq.1419.

Rodrigues-Canero, R., Martin-Algarra, A., Sarmiento, G.N., \& Navas-Parejo, P. (2010). First Late Ordovician conodont fauna in the Betic Cordillera (South Spain): A palaeobiographical contribution. Terra Nova, 22(5), 330-340. https://doi.org/10.1111/j.1365-3121.2010.00954.x.

Ruzhentsev, S.V., Pospeleov, I.I., \& Badarch, G. (1992). Tectonics of Baruunkhuurai Basin, Mongolia. Geotectonics, 22(1), 67-77.

Safonova, I., Kotlyarov, A., Krivonogov, S., \& Xiao, W. (2017). Intraoceanic arcs of the PaleoAsian Ocean. Gondwana Research, 50, 167-194. https://doi.org/10.1016/j.gr.2017.04.005.

Saltzmann, M.R., Groessens, E., \& Zhuravlev, A.V. (2004). Carbon cycle models based on extreme changes in $\delta 13 \mathrm{C}$ : An example from the lower Mississippian. Palaeogeography, Palaeoclimatology, Palaeoecology, 213, 359-377.

Salzmann, M.R. (2001). Silurian $\delta 13 C$ stratigraphy: A view from North America. Geology, 29, 671-674.

Sandberg, C.A., Ziegler, W., \& Bultynck, P. (1989). New standart conodont zones and early Ancyrodella phylogeny across the Middle-Upper Devonian boundary. Courier Forschungsinstitute Senckenberg, 110, 195-230.

Sandberg, C.A., Ziegler, W., Leuteritz, K., \& Brill, S.M. (1978). Phylogeny, speciation, and zonation of Siphonodella (Conodonta, Upper Devonian and Lower Carboniferous). Newsletters on Stratigraphy, 7(2), 102-120.

Scholle, P.A., Stemmerik, L., Ulmer-Scholle, D.S., Di Liegro, G., \& Henk, F.H. (1993). Palaeokarst-influenced depositional and diagenetic patterns in Upper Permian carbonates and evaporites, Karstrygen area, central East Greenland. Sedimentology, 40, 895-918.

Schönlaub, H.P., Klein, P., Magaritz, M., Rantitsch, G., \& Scharbert, S. (1991). Lower Carboniferous Paleokarst in the Carnic Alps. Facies, 25, 91-118.

Spalletta, C., Perri, M.C., Over, D.J., \& Corradini, C. (2017). Famennian (Upper Devonian) conodont zonation: Revised global standard. Bulletin of Geosciences, 91, 31-57. https://doi.org/10.3140/bull.geosci.1623. 
Stern, R.J., \& Scholl, D.W. (2010). Yin and yang of continental crust creation and destruction by plate tectonic processes. International Geology Review, 52, 1-31. https://doi.org/10.1080/00206810903332322.

Suetenko, O.D., Sharkova, T.T., \& Ulitina, K.M. (1977). Paleozoic stratigraphy and fauna of the eastern spurs of Gobian Altai (Mandal-Ovoo massif). Transactions Joint Soviet-Mongolian Paleontological Expedition, 5, 32-48 [In Russian].

Thassanapak, H., Udchachon, M., \& Burrett, C. (2012). Devonian radiolarians and tentaculitids from Central Laos. Journal of Asian Earth Science, 60, 104-113. https://doi.org/10.1016/j.jseaes.2012.08.002.

Thompson, T.L., \& Fellows, L.D. (1970). Stratigraphy and conodont stratigraphy of Kinderhookian and Osagean rocks of south western Missouri and adjacent areas. Missouri Geological Survey and Water Resources Report of Investigations, 39, 3-263.

Tucker, M.E. (2001). Sedimentary petrology: An introduction to the origin of sedimentary rocks. Oxford, 3rd edition, 262.

Ulmishek, G.F. (1988). Upper Devonian-Tournaisian facies and oil resources of the Russian cratons eastern margin. In N.J. McMillan, A.F. Embry, \& D.J. Glass, (Eds.), Devonian of the world, volume I: Regional syntheses. Canadian Society of Petroleum Geologist, Memoir, 14, $527-549$.

Voges, A. (1959). Conodonten aus dem Unterkarbon I and II (Gattendorfia und Pericyclus-Stufe) des Sauerlandes. Paläontologische Zeitschrift, 3, 266-314.

Vorozhbitov, A.M. (1997). Conodonts from the Yarovian Horizon (Lower Silurian) of Gornyi Altai. Stratigraphy and Geological Correlation, 4(1), 101-105 [In Russian].

Walliser, O.H. (1996). Global events in the Devonian and Carboniferous. In O.H. Walliser (Ed.), Global events and event stratigraphy in the Phanerozoic (pp. 225-250). Berlin, Heidelberg: Springer.

Wang, C.Y., \& Minjin, Ch. (2004). Early carboniferous age for Arynshand Formation, Mongolian South Gobi, based on conodonts. Alcheringa Australasian Journal of Palaeontology, 28(2), 433-440. https://doi.org/10.1080/03115510408619293.

Wang, Y.J., Aitchison, J.C., \& Luo, H. (2003a). Devonian radiolarian faunas from South China. Micropaleontology, 49(2), 127-145.

Wang, C.Y., Ziegler, W., Minjin, C., Sersmaa, G., Munchtsetseg, J., Gereltsetseg, L., \& Izokh, N. (2003b). The first discovery of the earliest Devonian conodont zonal fossil from the "Gavuu Member" in Mushigai area of South Gobi, Mongolia. Journal of Geoscientific Research in Northeast Asia, 6(1), 14-20. 
Wang, C.Y., Weddige, K., \& Minjin, C. (2005). Age revision of some Palaeozoic strata of Mongolia based on conodonts. Journal of Asian Earth Sciences, 25, 759-771.

Waters, J.A., Waters, J.W., Königshof, P., Carmichael, S.K., \& Ariuntogos, M. (2021). Famennian Crinoids and Blastoids (Echinodermata) from Mongolia. Palaeobiodiversity and Palaeoenvironments, 101(3). https://doi.org/10.1007/s12549-020-00450-3.

Westphal, H., Eberli, G.P., Smith, L.B., Grammer, G.M., \& Kislak, J. (2004). Reservoir characterization of the Mississippian Madison Formation, Wind River basin, Wyoming. The American Association of Petroleum Geologists Bulletin, 4, 405-432.

Wilson, I.G. (1975). Carbonate facies in geologic history (p. 471). Berlin: Springer-Verlag.

Windley, B.F., Alexeiev, D., Xiao, W., Kröner, A., \& Badarch, G. (2007). Tectonic models for accretion of the Central Asian Orogenic Belt. Journal of the Geological Society, 164, 31-47. https://doi.org/10.1144/0016-76492006-022.

Wonganan, N., \& Caridroit, M. (2005). Middle and Upper Devonian radiolarian faunas from Chiang Dao area, Chiang Mai province, northern Thailand. Micropaleontology, 51(1), 39-57.

Xiao, W., \& Santosh, M. (2014). The western Central Asian orogenic belt: A window to accretionary orogenesis and continental growth. Gondwana Research, 25(4), 1429-1444. https://doi.org/10.1016/j.gr.2014.01.008.

Xiao, W.J., Huang, B.C., Han, C.M., Sun, S., \& Li, J.L. (2010). A review of the western part of the Altaids: A key to understanding the architecture of accretionary orogens. Gondwana Research, 18(2-3), 253-273. https://doi.org/10.1016/j.gr.2010.01.007.

Yang, G., Li, Y., Tong, L., \& Yang, B. (2015). Oceanic Island basalts from the Darbut and Karamay Ophiolitic Mélange in West Junggar (NW China): Product of a Middle Devonian mantle plume? Acta Geologica Sinica, 89, 105-106. https://doi.org/10.1111/1755$\underline{6724.12308 \_63 .}$.

Yang, G., Li, Y., Tong, L., Wang, Z., Duan, F., Xu, Q., \& Li, H. (2019). An overview of oceanic island basalts in accretionary complexes and seamounts accretion in the western Central Asian orogenic belt. Journal of Asian Earth Sciences, 179, 385-398. https://doi.org/10.1016/j.jseaes.2019.04.011.

Zhang, S., Jowett, M.S., \& Barnes, C.R. (2017). Hirnantian (Ordovician) through Wenlock (Silurian) conodont biostratigraphy, bioevents, and integration with graptolite biozones, Cape Phillips formation slope facies, Cornwallis Island, Canadian Arctic Islands. Canadian Journal of Earth Sciences, 54(9), 936-960. https://doi.org/10.1139/cjes-2017-0023.

Ziegler, W., \& Sandberg, C.A. (1990). The Late Devonian standard conodont zonation. Courier Forschungsinstitut Senckenberg, 121, 1-115. 
Zonenshain, L.P., Suetenko, O.D., Jamyandamba, L., \& Eenjin, G. (1975). Structure of the axial part of south Mongolian eugeosyncline in the Dzolen range. Geotectonics, 4, 28-44. 


\section{Chapter 5}

Summary (This summary also considers results of two other published papers (Roelofs et al. 2021; Waters et al. 2021)

In the frame of the research project we studied the Late Devonian to (?) Early Mississippian Hushoot Shiveetin gol section in the Baruunhuurai Terrane (south-western Mongolia) of the CAOB. Based on new conodont data (Munkhjargal et al. 2021) the section ranges from the Palmatolepis minuta minuta conodont Zone to at least the Palmatolepis rugosa trachytera Zone. Although we could not pinpoint the $\mathrm{D} / \mathrm{C}$ boundary due to facies, it seems likely that the arkosic sandstone represents uppermost Famennian sediments and the D/C boundary occurs most probably in Unit VIII of the section (Munkhjargal et al. 2021). Depositional facies of the section exhibit a range from shallow-intertidal to outer ramp settings. Thus, it was difficult to pinpoint further Devonian events because the typical black-shale facies did not occur in the section. So, we hope that ongoing studies (in prep.) will provide geochemical signals, independently of the lithology of the sediments. The Hushoot Shiveetin gol section represents a characteristic island arc setting. The environmental setting was characterized by coeval subaerial volcanism resulting in numerous pyroclastic deposits. We mapped more than 40 bentonite layers in the Late Devonian (Famennian) which raises the question whether strong volcanic activity has been the "killing mechanism" for the Late Devonian events. In studies from Vietnam and in South Tian Shan Paschall et al. (2019) and Rakocinski et al. (2021) reported large amounts of mercury in sedimentary rocks as result of strong volcanic activity. Our results support the assumption that the late Famennian interval was a time of intensive volcanic activity, which may have led to significant changes in the global climate and biosphere which may have also affected fauna in shallow-water successions, such as shark diversity (Roelofs et al. 2021).

The depositional environments and intense volcanic activity at the Hushoot Shiveetin gol section limited the stratigraphic distribution, abundance, and diversity of some faunal elements, such as brachiopods while some others like ostracods and crinoids are abundant. From this section we could describe the first rich ostracod fauna from this area. The ostracod fauna consists of 19 genera and 25 species (Nazik et al. 2021). The Mongolian ostracod fauna is very rich in specimens and similar to coeval faunas in western China and Laurussia. Ostracods from the Hushoot Shiveetin gol section contain cosmopolitan, but also new, endemic species. With Beyrichiopsis hushootensis and Ampuloides beckeri two new species were described. The overall ostracod fauna of the Hushoot Shiveetin gol section is considered to be equivalent to the Eifelian mega-assemblage. The diverse ostracod fauna supports the idea of the CAOB as a biodiversity hotspot in the aftermath of the Frasnian/Famennian extinction (Waters and Webster 2009; Tolokonnikova and Ernst 2010; Nazik et al. 2021).

Macrofossils such as trilobites have been also found in this section. Studied material is often incomplete, difficult to prepare, but also some distinct horizons yielded relatively well-preserved phacopid trilobites (Crônier et al. 2021). In the early Famennian, the post-Kellwasser event 
recovery marked a new step especially for phacopid trilobites and the evolutionary pattern in phacopids shows a major increase in the specific origination during the late early Famennian (e.g. Crônier et al. 2013). Our study on trilobites from the southwestern Mongolia provides an update for species and subspecies currently known for the Famennian, particularly in comparison with sections in western Junggar of Xinjiang (Hongguleleng Formation).

[We also investigated the shallow-water vertebrate fauna found in this section (Roelofs et al. 2021). There was a major change in the diversity of jawed vertebrate faunas following the Frasnian-Famennian mass extinction event (374 Ma). Placoderms which had been the dominant taxa, both in terms of diversity and abundance showed a significant decline post the FrasnianFamennian mass extinction event with sharks showing an increased diversity, first in shallow water environments and then deeper open-water environments (Burrow et al. 2008). In comparison with contemporaneous shark faunas, the chondrichthyan fauna described from our section shows a lack of diversity. This low diversity fauna differs significantly from the high diversity invertebrate faunas described from Hushtoot Shivteetiin gol section (Crônier et al. 2021; Munkhjargal et al. 2021; Nazik et al. 2021; Waters et al. 2021). The presence of other pangeographic taxa such as conodonts, ostracods and crinoids indicate that there was not a physical barrier preventing colonisation of the habitat and so the siliciclastic-dominated sedimentation (including coeval subaerial volcanism) of the Baruunhuurai Terrane may have been the limiting factor in chondrichthyan diversity] (see above)

[In contrast to the low diversity of jawed vertebrates, we found the most abundant and diverse fauna of Palaeozoic crinoids and blastoids collected from Mongolia to date (Waters et al. 2021). The fauna of this section consists of two genera of blastoids and twelve genera of crinoids - four genera of camerates, three genera of flexibles, one disparid genus and four genera of cladids. The crinoids and blastoids were living on an active island arc complex in the Central Asian Orogenic Belt (CAOB) in a high physical stress environment with frequent and often voluminous pyroclastic eruptions. The Mongolian fauna is similar to coeval faunas collected from the Honggulelung Formation in western China (Waters et al. 2003; Webster and Waters 2009) and supports the hypothesis that the CAOB was a biodiversity hotspot for Famennian echinoderms and a precursor to the very successful echinoderm communities that dominated Mississippian shallow-marine ecosystems globally. Three new taxa are described. Mongoliacrinus minjini, new genus and species, is the oldest member of the Acrocrinidae, previously known from the Mississippian and Pennsylvanian and the first occurrence of the family outside North America. Eutaxocrinus ariunai and Eutaxocrinus sersmaai are new species of the flexible crinoid Eutaxocrinus, a genus with a widespread distribution during the Early and Middle Devonian, which survived into the Lower Mississippian. It is restricted to the CAOB in the Late Devonian] (see above)

The disparity of information in different depositional settings and areas fundamentally hampers knowledge on climate change and faunal change during and in the aftermath of global extinction events. As a step towards addressing problems of palaeogeographic sample bias, biostratigraphy, 
and biodiversity changes in the aftermath of the Frasnian-Famennian events we could present results from a shallow-subtidal to outer ramp settings within the Central Asian Orogenic Belt which is an important contribution to understand biodiversity patterns in isolated ecosystems during a time of global climate changes.

As a result of the field trip in 2019 we investigated the Bayankhoshuu Ruins section in the southern Gobi of Mongolia. We have sampled three sections ranging from Ordovician to Silurian close to our field camp and a cross-section near the Bayankhoshuu Ruins which was subdivided into different sections (Munkhjargal, Königshof et al. 2021). In the last two decades, significant progress has been made in understanding the complex plate tectonic dynamics by studies on geochronological, geochemical, and isotope dating preferably from magmatic and metamorphic rocks (Badarch et al. 2002; Windley et al. 2007; Xiao et al. 2010; Kröner et al. 2014; Xiao and Santosh 2014; Safonova et al. 2017; Yang et al. 2019, among others). Papers outlining the terranes and tectonic history of Mongolia do not necessarily have broad generalizations about the geology of specific areas. Although several petrological, geochemical, and structural studies were conducted to get a better understanding on the complex framework of the $\mathrm{CAOB}$, detailed sedimentological and stratigraphical descriptions are scarce.

We could show that facies analysis combined with stratigraphic data provide improved lithostratigraphic descriptions of Palaeozoic successions in the Mushgai region. Although many more conodont samples are necessary in order to provide a better biostratigraphic record, our data (Munkhjargal, Königshof et al. 2021) provide new sedimentological and stratigraphical descriptions from the Bayankhoshuu Ruins section (Mushgai area, southern Mongolian Gobi):

The Bayankhoshuu Ruins section is characterized by strongly thrusted and folded sequences which contain relatively scarce fossils except some distinct horizons. However, based on our study the Bayankhoshuu Ruins section ranges from the Late Ordovician (Khoyormod Formation) to the early Mississippian (Arynshand Formation). The Bayankhoshuu Ruins section exposes mainly deep-water (hemipelagic and pelagic) deposits composed of limestones, siltstones, and cherts, shallow-water sediments are less frequent. Late Devonian and Mississippian rocks of the Bayankhoshuu Ruins section are not comparable with the shallow-water Hushoot Shiveetiin gol section (Baruunhuurai Terrane) in western Mongolia where a reasonably abundant and diverse macrofauna has described (Crônier et al. 2021; Nazik et al. 2021; Munkhjargal et al. 2021; Waters et al. 2021) but facies settings of both sections are characterized by very strong volcanic activity, particularly in the Late Devonian. The marine sedimentary succession is interjected by volcanic rocks - basaltic lava of Silurian and Middle Devonian age and volcaniclastic bentonite and tuff in the Middle to Late Devonian and Mississippian which can reach a remarkable thickness. Two distinct types of volcanic activity are observed in the section. Basalts consistent with back arc spreading are dominant in the Middle to Late Devonian of the Bayankhoshuu Ruins section (Fig. 1). The 
Devonian basalts are very thick. The presence of pillow structures in the Devonian basalts indicates active sea floor extrusion. Pyroclastic rocks and bentonites prove periodic subaerial extrusion and occur preferably in the Middle to Late Devonian and are of small importance in the Mississippian. Prolonged volcanic activity particularly in the Late Devonian are reported from many places around the world and has been suggested to be a driver of ecological collapse at the D/C boundary (e.g. Moreno et al. 1996; Paschall et al. 2019; Racki et al. 2018; 2019). Intercalations of deep water (radiolarian-rich) siltstone and chert indicate multiple periods of sea floor spreading. The section contains more than 20 bentonite layers some more than two meter-thick in outcrop. The bentonites indicate a more distant, more explosive volcanic source likely associated with subduction rather than back arc development. Deposits of the Bayankhoshuu Ruins section suggesting an island arc setting. Overall, deposition likely occurred on either the Mandalovoo- or Gurvansayhan Terrane.

\begin{tabular}{|c|c|c|c|c|c|c|c|c|}
\hline System & Stages/Series & \multirow{2}{*}{\multicolumn{2}{|c|}{$\begin{array}{l}\text { Minjin et al. } 2001 \\
\text { Tal } \\
\text { Formation }\end{array}$}} & \multicolumn{2}{|c|}{ Wang et al. 2005} & \multicolumn{3}{|c|}{ This study } \\
\hline \multirow{2}{*}{ 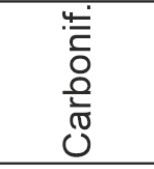 } & Pennsylvanian & & & & $\begin{array}{l}\text { Tal } \\
\text { Formation }\end{array}$ & & ol & \\
\hline & Mississippian & \multirow{2}{*}{\multicolumn{2}{|c|}{$\begin{array}{l}\text { Arynshand } \\
\text { Formation }\end{array}$}} & \multicolumn{2}{|c|}{ Arynshand Fm. } & \multicolumn{2}{|c|}{ Arynshand Fm. } & \\
\hline \multirow{8}{*}{ 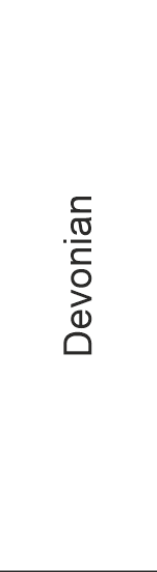 } & Famennian & & & & $?$ & \multirow{5}{*}{ 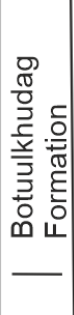 } & \multirow{3}{*}{ Minjin Mbr. } & \\
\hline & Frasnian & \multirow{4}{*}{ 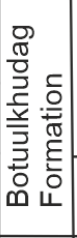 } & \multirow{2}{*}{ Minjin Mbr. } & \multirow{2}{*}{\multicolumn{2}{|c|}{ Minjin Mbr. }} & & & \\
\hline & Givetian & & & & & & & \\
\hline & \multirow{2}{*}{ Eifelian } & & \multirow{2}{*}{ Takhuul Mbr. } & & ? & & \multirow{2}{*}{$\stackrel{?}{\text { Takhuul Mbr. }}$} & \\
\hline & & & & \multicolumn{2}{|r|}{ Takhuul Mbr. } & & & \\
\hline & Emsian & \multirow{2}{*}{ 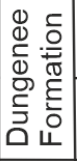 } & Murugtsug Mbr. & \multicolumn{2}{|r|}{ Dungenee Fm. } & \multicolumn{2}{|c|}{ Dungenee Fm. } & \\
\hline & Pragian & & Sandstone & \multirow{2}{*}{\multicolumn{2}{|c|}{ 二 Olonovoot Fm. }} & & \multirow{2}{*}{$\begin{array}{l}\stackrel{?}{B} \\
\text { Bioherm } \\
\text { Massflow dep. }\end{array}$} & \\
\hline & Lochkovian & केष्छ & \begin{tabular}{|l|} 
Reef \\
Conglomerate
\end{tabular} & & & & & \\
\hline \multirow{4}{*}{$\frac{\frac{c}{\sqrt[0]{5}}}{\frac{\bar{J}}{\bar{c}}}$} & Pridoli & \multirow{5}{*}{ 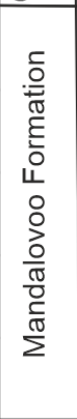 } & \multirow[b]{2}{*}{$\begin{array}{l}\text { Hanyndoloon } \\
\text { Member }\end{array}$} & \multirow{5}{*}{ 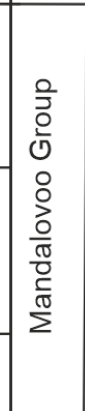 } & ? & & \multirow{2}{*}{$\begin{array}{l}\text { Hanyndoloon } \\
\text { Member }\end{array}$} & \multirow[b]{2}{*}{80} \\
\hline & Ludlow & & & & $\begin{array}{l}\text { Hanyndoloon } \\
\text { Member }\end{array}$ & \multirow{3}{*}{ 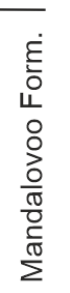 } & & \\
\hline & Wenlock & & \multirow{2}{*}{$\begin{array}{l}\text { Gavuu } \\
\text { Member }\end{array}$} & & ||$\underline{|l|}$ & & \multirow{2}{*}{$\begin{array}{l}\text { Gavuu } \\
\text { Member }\end{array}$} & $?$ \\
\hline & Llandovery & & & & $\begin{array}{l}\text { Gavuu Fm. } \\
\text { (lower part) }\end{array}$ & & & \\
\hline कें & Ashgillian & & $\begin{array}{l}\text { Khoyormod } \\
\text { Member }\end{array}$ & & $\begin{array}{l}\text { Khoyormod } \\
\text { Formation }\end{array}$ & & $\begin{array}{l}\text { Khoyormod } \\
\text { Formation }\end{array}$ & 80 \\
\hline
\end{tabular}

Fig. 1. Stratigraphic chart of formations/members of the Bayankhoshuu Ruins section combined with tectonic and volcanic events of southern Mongolia, Mandal Ovoo area.

We could improve the stratigraphy of some formations although microfossils such as conodonts and radiolarians are poorly preserved (Fig. 1). However, based on the re-study of 
collections from earlier publications and new conodont data, a more detailed biostratigraphic record of the Khoyormod-, Botuulkhudag-, and Arynshand formations of the Bayankhoshuu Ruins section can be developed. For instance, the Arynshand Formation likely ranges from the late Bispathodus ultimus conodont zone to the Scaliognathus anchoralis-Doliognathus latus zone. Furthermore, we have some evidence of occurring equivalents of event layers such as the Ordovician Extinction Event (Hirnantian) although the stratigraphy needs more detailed analysis. Based on sedimentological characteristics and biostratigraphical data it seems likely that the Devonian/Carboniferous transition - in contrast to earlier publications - is not exposed in the Bayankhoshuu Ruins section which can be explained by thrusting. Due to the general rareness of fossils, poor preservation and strong tectonic overprint it was not possible to pinpoint the Late Devonian event layers in the Bayankhoshuu Ruins section, but we provide more detailed information on the placement of the succession within the Palaeozoic Terrane scheme for Mongolia Munkhjargal et al. (2021).

\section{Conclusion}

In the frame of our international research project we achieved most goals defined in the project proposal, but there is also a need to continue our study because of limited biostratigraphic control. Nevertheless, we have made progress in respect to events, stratigraphy, palaebiogeography, definition of formations/members and regional geology.

- Although we could not pinpoint Late Devonian events, it seems likely that the Hushoot Shiveetiin gol section contains the D/C boundary. The first thick-bedded sandstone may represent an equivalent to the Hangenberg Sandstone. In much older successions of the Bayankhoshuu Ruins section, in the Ordovician, conodont findings point to equivalent sediments, representing the Hirnantian Extinction Event, whereas the D/C boundary is not exposed in this section, which is in contrast to earlier publications.

- Based on our conodont study, we could improve and confirm the stratigraphical range of the Hushoot Shiveetiin gol section ranging from the Palmatolepis minuta minuta Biozone to Palmatolepis rugosa trachytera Biozone which suggests a Famennian to early Mississippian age (including the conformably overlying succession).

- Different fossil groups have been investigated and provide new data: 25 ostracod species belonging to 19 genera are reported for the first time from the Late Devonian in western Mongolia. The findings confirm the Eifelian-Mega-Assemblage I-III, representing a variable nearshore environment, which is confirmed by facies analysis.

- The crinoid fauna described from the same section (Hushoot Shiveetiin gol section) is the largest and most diverse Palaeozoic crinoid fauna from Mongolia. The two genera of blastoids are the first reports of this class from Mongolia.

- Both, echinoderm and ostracod faunas support the hypothesis that the CAOB was a biodiversity hotspot in the aftermath F/F extinction (Nazik et al. 2021; Waters et al. 2021). Echinoderms are a precursor to the very successful echinoderm communities 
that dominated Mississippian shallow-marine ecosystems globally (Waters et al. 2021).

- The number of trilobites which were found in the section reveals the endemic nature of many genera and some new species are described (Crônier et al. 2021).

- 22 teeth of microvertebrates recovered, 19 teeth were assigned to Jungarrensis ambiguus gen. et sp. nov. with three teeth attributed to other 'Cladodonts'. In contrast to the diverse echinoderm and ostracod fauna, the diversity of the chondrichthyan fauna is low and suggests that the western Mongolian region of the CAOB did not provide similar refugia for shark faunas or represented a chondrichthyan biodiversity hotspot. However, Jungarrensis ambiguus gen. et sp. nov. appears to be the dominant shark fauna in the shallow-water environments of the Central Asian Orogenic Belt region (Roelofs et al. 2021).

- We could improve the biostratigraphy of the Mushgai area based on conodont and radiolarian fauna, which resulted in the revision of stratigraphical ranges of formations and members, e.g. the Arynshand Formation likely ranges from the Late Bispathodus ultimus Zone to the Scaliognathus anchoralis-Doliognathus latus Zone.

- In terms of regional geology, we provide a much better lithological description of occurring formations, and we have shown that submarine and/or subaerial volcanism in both regions obviously play an important role during the Late Devonian, which supports the hypothesis that volcanism may have acted as a trigger for the Late Devonian events. 
Zusammenfassung (Diese Zusammenfassung berücksichtigt auch die Ergebnisse der Publikationen Waters et al. 2021; Roelofs et al. 2021)

Im Rahmen des Forschungsprojekts untersuchten wir das oberdevonische bis (?) unterkarbonische Hushoot Shiveetin gol Profil im Baruunhuurai Terrane (südwestliche Mongolei) des CAOB. Basierend auf neuen Conodonten-Daten (Munkhjargal et al. 2021) reicht das Profil von der Palmatolepis minuta minuta Conodonten Zone bis mindestens zur Palmatolepis rugosa trachytera Zone. Obwohl wir die D/C-Grenze aufgrund der Fazies nicht genau bestimmen konnten, scheint es wahrscheinlich, dass der arkosische Sandstein oberste Famennische Sedimente repräsentiert und die D/C-Grenze höchstwahrscheinlich in der Einheit VIII des Abschnitts liegt (Munkhjargal et al. 2021). Die Faziesanalyse des Profils weist auf eine Bandbreite von flach-intertidalen bis voll marinen (outer ramp) Ablagerungen hin. Aufgrund der Faziesverhältnisse war es schwierig, weitere devonische Aussterbeereignisse (Events) zu lokalisieren, da die typische Schwarzschiefer-Fazies in dem untersuchten. Abschnitt nicht vorkam. Wir hoffen daher, dass laufende Studien (in prep.) unabhängig von der Lithologie der Sedimente geochemische Signale liefern werden. Das Hushoot Shiveetin gol Profil repräsentiert Ablagerungen eines typischen Inselbogens Profils. Umweltbedingungen waren auch gekennzeichnet durch subaerischen Vulkanismus, der $\mathrm{zu}$ zahlreichen pyroklastischen Ablagerungen führte. Wir haben mehr als 40 Bentonite im oberen Devon (Famennium) kartiert, was die Frage aufwirft, ob der starke Vulkanismus als der „Auslöser“ für die spät-devonischen Events war. In Studien aus Vietnam und aus dem südlichen Tian Shan beschreiben Paschall et al. (2019) und Rakocinski et al. (2021) große Mengen an Quecksilber in Sedimentgesteinen, was, als Folge starker vulkanischer Aktivität angesehen wird. Unsere Ergebnisse unterstützen diese Annahme, dass das späte Famennium-Intervall eine Zeit intensiver vulkanischer Aktivität war, die zu signifikanten Veränderungen des globalen Klimas und der Biosphäre geführt haben könnten.

Die Ablagerungsbedigungen und die intensive vulkanische Aktivität im Hushoot Shiveetiin gol Profil schränkten die stratigraphische Genauigkeit, den Fossilreichtum und die Vielfalt einiger Faunenelemente ein, so z.B. die Brachiopoden, während einige andere wie Ostracoden und Crinoiden reichlich vorhanden sind. So konnten wir von diesem Profil die erste reiche Ostracoden-Fauna aus diesem Gebiet beschreiben. Die Ostrakoden-Fauna besteht aus 19 Gattungen und 25 Arten (Nazik et al. 2021). Die mongolische Ostrakoden-Fauna ist sehr artenreich und ähnelt den gleichaltrigen Faunen in Westchina und Laurussia. Die Ostracoden aus dem Hushoot Shiveetin gol Profil enthalten überwiegend kosmopolitische Formen; aber auch neue, endemische Arten. Mit Beyrichiopsis hushootensis und Ampuloides beckeri wurden zwei neue Arten beschrieben. Die gesamte Ostracoden-Fauna des Hushoot Shiveetin gol Profils wird faunistisch als gleichwertig mit der Eifel-Mega-Assemblage I-III angesehen. Die vielfältige Ostracoden-Fauna unterstützt die Idee des CAOB als Biodiversitäts-Hotspot in der Zeit nach dem Frasnium/Famennium Event (Waters und Webster 2009; Tolokonnikova und Ernst 2010; Nazik et al. 2021). 
Makrofossilien wie Trilobiten wurden ebenfalls in diesem Profil gefunden. Das untersuchte Material ist oft unvollständig und schwer zu präparieren, wenngleich auch einige ausgeprägte Horizonte relativ gut erhaltene phacopide Trilobiten lieferten (Crônier et al. 2021). Im frühen Famennium markierte die Erholung nach dem Kellwasser-Ereignis einen neuen Schritt für die Trilobiten. Insbesondere phacopide Trilobiten zeigen spezifische Evolutionsmuster während des späten Abschnittes im frühen Famennium (z.B. Crônier et al. 2013). Unsere Studie über die Trilobiten aus der südwestlichen Mongolei aktualisiert die Daten über die derzeit für das Famennium bekannten Arten und Unterarten, insbesondere im Vergleich mit Abschnitten im westlichen Junggar von Xinjiang (Hongguleleng-Formation).

[Wir untersuchten auch die gefundene Flachwasser-Wirbeltierfauna dieses Profils (Roelofs et al. 2021). Nach dem Frasnium/Famennium Massenaussterbeereignis (374 Ma) gab es eine große Veränderung in der Vielfalt der Kiefertragenden Wirbeltierfauna. Placodermen, die sowohl in Bezug auf die Vielfalt als auch auf die Abundanz die dominierenden Taxa waren, zeigten nach dem F/F Event einen signifikanten Rückgang, während Haie zunächst in flachmarinen Habitaten und später auch in offen-marinen Bereichen eine erhöhte Vielfalt aufwiesen (Burrow et al. 2008). Im Vergleich zu zeitgleichen Haifaunen anderer Pfofile zeigt die beschriebene Chondrichthyan-Fauna aus unserem Profil einen Mangel an Diversität. Diese Fauna mit geringer Diversität unterscheidet sich signifikant von den hochdiversen Wirbellosen-Faunen, die aus dem Hushtoot Shivteetiin gol Profil beschrieben wurden (Crônier et al. 2021; Munkhjargal et al. 2021; Nazik et al. 2021; Waters et al. 2021). Das Vorhandensein anderer pangeographischer Taxa wie Conodonten, Ostracoden und Crinoiden deutet darauf hin, dass es keine physische Barriere gab, die Besiedlung des Lebensraums verhinderte, so dass die siliklastisch-dominierte Sedimentation (einschließlich des gleichzeitigen subaerischen Vulkanismus) des BaruunhuuraiTerrains der begrenzende Faktor für die Chondrichthyan-Diversität gewesen sein könnte]. (siehe oben)

[Im Gegensatz zu der geringen Diversität der Kiefertragenden Wirbeltiere fanden wir die reichhaltigste und vielfältigste Fauna von Paläozoischen Crinoiden und Blastoiden, die bisher in der Mongolei beschreiben wurde (Waters et al. 2021). Die Fauna dieses Profils besteht aus zwei Gattungen von Blastoiden, zwölf Gattungen von Crinoiden - vier Gattungen von Cameraten, drei Gattungen von Flexiblen, eine Gattung von Dispariden und vier Gattungen von Cladiden. Die Crinoiden und Blastoiden lebten auf einem aktiven Inselbogenkomplex im zentralasiatischen orogenen Gürtel (CAOB) in einer Umgebung mit hoher physikalischer Belastung mit häufigen und oft voluminösen, pyroklastischen Eruptionen. Die mongolische Fauna ähnelt gleichaltrigen Faunen, die aus der Honggulelung-Formation in Westchina gesammelt wurden (Waters et al. 2003; Webster und Waters 2009) und unterstützt die Hypothese, dass der CAOB ein Biodiversitäts-Hotspot für Famennische Stachelhäuter und ein Vorläufer der sehr erfolgreichen Stachelhäuter-Gemeinschaften war, welche die frühen (Mississippium)-Flachmeer-Ökosysteme weltweit dominierten. Drei neue Taxa werden beschrieben. Mongoliacrinus minjini, eine neue Gattung und Art, ist das älteste Mitglied der Acrocrinidae, das bisher aus dem Mississippium und 
Pennsylvanium bekannt war und das erste Vorkommen der Familie außerhalb Nordamerikas. Eutaxocrinus ariunai und Eutaxocrinus sersmaai sind neue Arten der flexiblen Seelilie Eutaxocrinus, einer Gattung die während des frühen und mittleren Devon seine weite Verbreitung hat und die bis in das untere Mississippium überlebte. Im Spätdevon ist sie auf den CAOB beschränkt]. (siehe oben)

Die Disparität der Informationen in verschiedenen Ablagerungsräumen und -gebieten begrenzt grundlegend das Wissen über Klimaveränderungen und Veränderungen der Fauna während und nach globalen Aussterbeereignissen. Um Probleme der palaeogeographischen Probenbegrenzung, der Biostratigraphie und der Biodiversitätsveränderungen in der Nachfolge der F/F Aussterbeereignisse zu minimieren, konnten wir Ergebnisse aus einem flach-subtidalen bis voll-marinen (outer ramp) Ablagerungsraum innerhalb des zentralasiatischen orogenen Gürtels präsentieren, was einen wichtigen Beitrag zum Verständnis der Biodiversitätsmuster in isolierten-in diesem Fall ozeanischen-Ökosystemen während einer Zeit globaler Klimaveränderungen darstellt.

Im Rahmen einer Expedition im Jahr 2019 untersuchten wir das Bayankhoshuu Ruins Profil in der südlichen Gobi der Mongolei. Wir haben in der Nähe unseres Feldlagers drei Abschnitte vom Ordovizium bis zum Silur untersucht als auch eine Abfolge in unmittelbarer Nähe des Bayankhoshuu Ruins beprobt welche in verschiedene Abschnitte unterteilt wurde (Munkhjargal, Königshof et al. 2021). In den letzten zwei Jahrzehnten wurden bedeutende Fortschritte im Verständnis der komplexen plattentektonischen Dynamik durch Studien über geochronologische, geochemische und isotopische Datierungen vorzugsweise aus magmatischen und metamorphen Gesteinen erzielt (Badarch et al. 2002; Windley et al. 2007; Xiao et al. 2010; Kröner et al. 2014; Xiao und Santosh 2014; Safonova et al. 2017; Yang et al. 2019, u.a.). Publikationen, die die Terranes und die tektonische Geschichte der Mongolei umreißen, enthalten nicht unbedingt allgemeine Grundlagen über die Geologie bestimmter Gebiete. Obwohl mehrere petrologische, geochemische und strukturelle Studien durchgeführt wurden, um ein besseres Verständnis hinsichtlich der Konplexität des $\mathrm{CAOB}$ zu erhalten, sind detaillierte sedimentologische und stratigraphische Beschreibungen eine Seltenheit.

In unserer Studie konnten wir zeigen, dass anhand der Faziesanalyse in Kombination mit neuen stratigraphischen Daten, die lithostratigraphische Beschreibungen von Paläozoischen Abfolgen in der Mushgai-Region verbessert werden könnte. Obwohl noch mehr Conodont-Proben notwendig sind, um eine bessere biostratigraphische Auflösung zu erreichen, liefern unsere Daten (Munkhjargal, Königshof et al. 2021)grundlegend neue sedimentologische und stratigraphische Beschreibungen aus dem Bayankhoshuu Ruins Profil (Mushgai-Gebiet, südliche mongolische Gobi):

Das Bayankhoshuu Ruins Profil ist durch stark geschuppte und gefaltete Sequenzen gekennzeichnet, die mit Ausnahme bestimmter Horizonte relativ wenige Fossilien enthalten. Basierend auf unserer Studie hat das Bayankhoshuu Ruins Profil eine stratigraphische 
Reichweite vom späten Ordovizium (Khoyormod-Formation) bis zum frühen Mississippium (Arynshand-Formation). Das Profil beinhaltet im Wesentlichen Tiefwasserablagerungen (hemipelagisch und pelagisch), die aus Kalksteinen, Siltsteinen und Hornsteinen bestehen, Flachwassersedimente sind weniger häufig. Die spätdevonischen und mississippischen Gesteine des Bayankhoshuu Ruins Profils sind nicht vergleichbar mit dem Flachwasser-Hushoot Shiveetiin gol Profil (Baruunhuurai Terrane) in der westlichen Mongolei, wo eine recht reichhaltige und vielfältige Makrofauna beschrieben wurde (Crônier et al. 2021; Nazik et al. 2021; Munkhjargal et al. 2021; Waters et al. 2021), Allerdings, sind beide Profile durch sehr starke vulkanische Aktivität gekennzeichnet, insbesondere im Spätdevon. Die marine Sedimentabfolge wird von vulkanischen Gesteinen durchsetzt. Basaltische Lava aus dem Silur und Mitteldevon sowie Bentonite und Tuffe im Mittel- bis Spätdevon und Mississippium, die eine beachtliche Mächtigkeit erreichen können. In dem Profil sind zwei verschiedene Arten von vulkanischer Aktivität zu beobachten. Im Mittel- bis Spätdevon dominieren Basalte, die mit back-arc spreading im Zusammenhang stehen (Abb. 1). Die devonischen Basalte sind sehr dick und das Vorhandensein von Pillow-Strukturen deutet auf submarinen Vulkanismus infolge von Dehnungstektonik hin. Pyroklastische Gesteine und Bentonite beweisen periodischen subaerischen Vulkanismus und treten vorzugsweise im Mittel- bis Spät Devon auf, im Mississippium ist der Vulkanismus von geringer Bedeutung. Anhaltende vulkanische Aktivität vor allem im Spätdevon ist von zahlreichen regionen der Welt bekannt und wurde als Ursache des ökologischen Zusammenbruchs an der D/C-Grenze vermutet (z.B. Moreno et al. 1996; Paschall et al. 2019; Racki et al. 2018; 2019). Einschaltungen von Tiefenwasser Sedimenten, wie (radiolarienreichen) Siltsteinen und Hornstein deuten auf phasenweise sea-floor spreading hin. Das Profil enthält zudem mehr als 20 Bentonit-Horizonte, von denen einige eine Mächtigkeit von mehr als zwei Meter haben. Die Bentonite deuten auf einen weiter entfernten, subaerischen Vulkanismus, der wahrscheinlich eher mit einer Subduktion als mit der Entwicklung eines backarc verbunden ist. Die Ablagerungen im hingegen imBayankhoshuu-Ruinen Profil deuten auf einen Inselbogenbildung hin. Insgesamt erfolgte die Ablagerung wahrscheinlich entweder auf dem Mandalovoo- oder dem Gurvansayhan-Terran.

Im Rahmen des Projektes konnten wir die stratigraphische Einordnung einiger Formationen verbessern, obwohl Mikrofossilien wie Conodonten und Radiolarien generell schlecht erhalten sind. Basierend auf der Überprüfüng von Sammlungsdaten aus früheren Publikationen und neuen Conodonten-Daten konnte somit eine detailliertere biostratigraphische Reichweite der Khoyormod-, Botuulkhudag- und Arynshand-Formationen des Bayankhoshuu Ruins Profils vorgenommen werden (Abb. 1). So reicht beispielweise die Arynshand-Formation wahrscheinlich von der späten Bispathodus ultimus Conodont-Zone bis zur Scaliognathus anchoralis-Doliognathus latus-Zone. Darüber hinaus haben wir stratigraphische Hinweise im untersuchten Profil auf Äquivalente eines Ordovizium-Events im Hirnantium, was, allerdings, einer genaueren Analyse bedarf. Basierend auf den sedimentologischen Kriterien und den biostratigraphischen Daten scheint es wahrscheinlich, dass der Übergang zwischen Devon und Karbon - im Bayankhoshuu Ruins Profil im Gegensatz zu früheren Veröffentlichungen - nicht 
aufgeschlossen ist, was durch eine Überschiebung erklärt werden kann. Aufgrund der grundsätzlichen Seltenheit und schlechten Erhaltung von Fossilien, sowie und der starken tektonischen Überprägung war es nicht möglich, die spätdevonischen Aussterbeereignisse im Bayankhoshuu Ruins Profil zu lokalisieren.

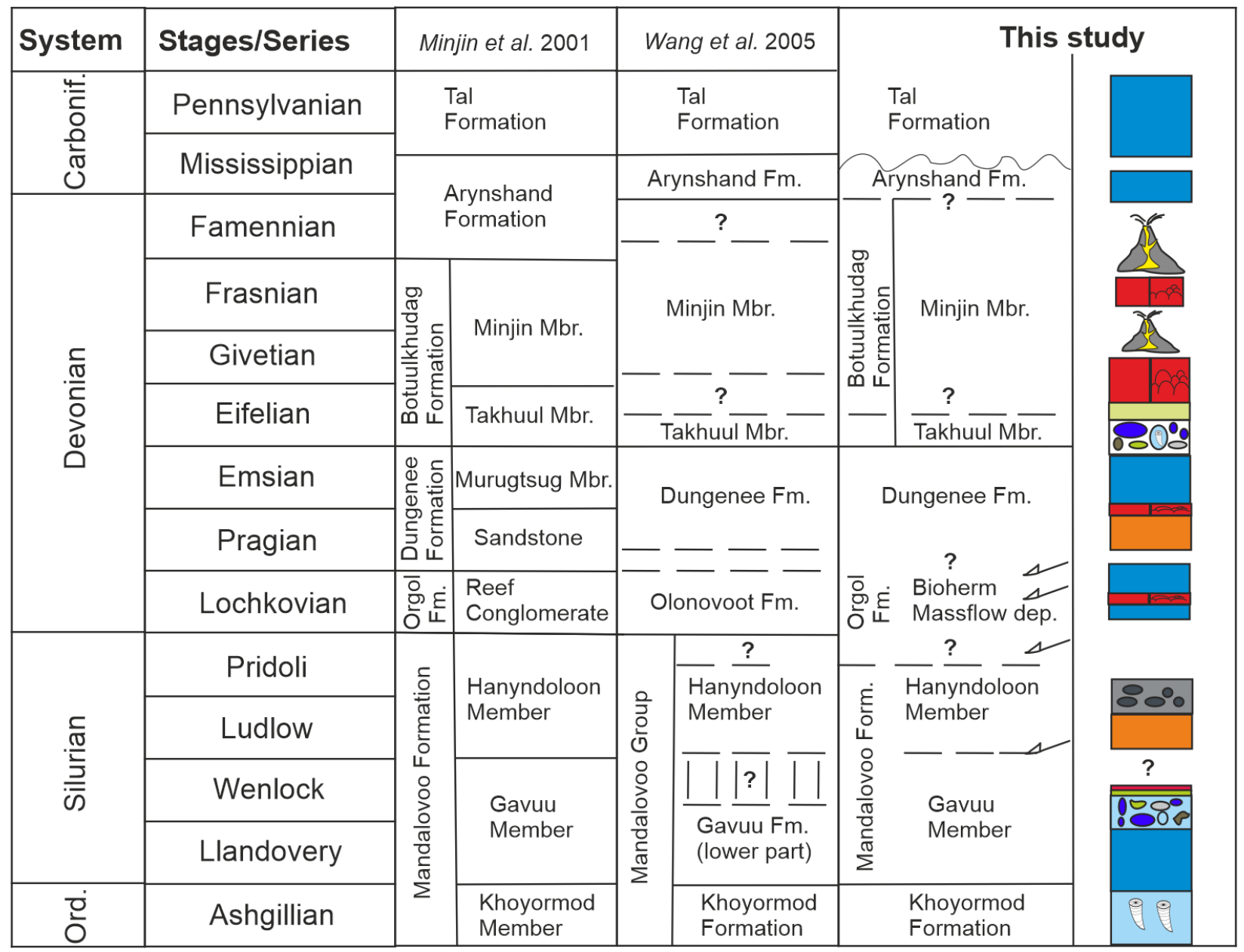

Abb. 1 Stratigraphische Karte der Formationen/Member des Profils Bayankhoshuu Ruins in Verbindung mit tektonischen und vulkanischen Ereignissen der südlichen Mongolei, Gebiet Mandal Ovoo.

Dennoch liefern unsere Untersuchungen detailliertere Informationen über die sedimentologische und zeitliche Entwickung des Profils innerhalb des Terrainmodels für die Mongolei (Munkhjargal et al. 2021).

\section{Schlussfolgerung}

Im Rahmen unseres internationalen Forschungsprogramms wurden die meisten Ziele erreicht, die im Projektantrag definiert waren, wobei allerdings noch weiterer Forschungsbedarf besteht aufgrund der begrenzten biostratigraphischen Auflösung. Trotzdem haben wir Fortschritte erzielt im Hinblick auf Aussterbeereignisse, Stratigraphie, Palaeobiogeographie, Definition von Formationen/Member als auch regionaler Geologie: 
- Obwohl wir nicht genau Spätdevonische Events fixieren konnten, ist es sehr wahrscheinlich, dass das Hushoot Shiveetin gol Profil die D/C Grenze beinhaltet. Der erste mächtige Sandstein repräsentiert möglicherweise das Äquivalent des Hangenberg Sandsteins. In wesentlich älteren Abfolgen des Bayankhoshuu Ruins Profils deuten Conodontenfunde aus dem Ordovicium auf das Hirnantian-Aussterbeereignis hin, wohingegen die D/C Grenze in diesem Profil nicht aufgeschlossen ist, was im Widerspruch zu früheren Publikationen steht.

- $\quad$ Basierend auf unseren Conodonten Studien konnten wir die stratigraphische Reichweite des Hushoot Shiveetiin gol-Profils bestätigen und verbessern. Das Profil hat eine stratigraphische Reichweite von der Palmatolepis minuta minuta Biozone bis zur Palmatolepis rugosa trachytera Biozone, was auf ein Alter vom Famennian bis tiefen Mississippian hinweist (inklusive der darüber folgenden, kontinuierlichen Abfolge).

- Unterschiedliche Fossilgruppen wurden untersucht und erbrachten zahlreiche neue Daten: 25 Ostracoden-Arten, die zu 19 Gattungen gehören, werden erstmalig aus dem späten Devon der westlichen Mongolei beschrieben. Die Daten deutet auf die Eifel-Mega-Assemblage I-III (Nazik et al. 2021) hin, welche auf einen küstennahen, variable Ablagerungsraum hinweist, was durch die Ergebnisse der Faziesanalyse belegt wird.

- Die beschriebene Crinoiden-Fauna desselben Profils (Hushoot Shiveetiin gol Profil) ist die größte und vielfältigste paläozoische Crinoiden-Fauna aus der Mongolei, die bislang beschrieben wurde. Die zwei Gattungen von Blastoiden sind die ersten dieser Klasse aus der Mongolei.

- Die diversen Echinodermen und Ostracoden Faunen unterstützen die Hypothese; dass die CAOB einen Biodiversitätshotspot in der Zeit nach dem F/F Event repräsentiert (Nazik et al. 2021; Waters et al. 2021); die Echinordemen sind Vorläufer einer erfolgreichen Echinodermen Vergesellschaftung, die später weltweit flach-marine Ökosysteme im Mississippum dominieren (Waters et al. 2021).

- Die gefundenen Trilobiten repräsentieren offensichtlich überwiegend endemische Formen, ebenso wurden neue Formen beschrieben (Cronier et al. 2021).

- $\quad 22$ Zähne von Kiefertragenden Wirbeltieren wurden untersucht, von denen 19 Zähne zu Jungarrensis ambiguus gen. et sp. nov. zugeordnet wurden, drei Zähne wurden anderen 'Cladodonts' zugeschrieben. Im Gegensatz zu den diversen Echinodermen und Ostracoden Faunen ist die Chondrichthyten-Fauna wenig divers, was darauf hindeutet, dass die westliche mongolische Region des CAOB keine ähnlichen Refugien für Haifisch-Faunen bot oder einen Hotspot der Chondrichthyten-Biodiversität darstellt. Allerdings scheint Jungarrensis ambiguus gen. et sp. nov. die dominante Haifauna in den Flachwasserumgebungen der zentralasiatischen orogenen Gürtelregion zu sein (Roelofs et al. 2021). 
- $\quad$ Basierend auf Conodonten und Radiolarien Funden konnte die Biostratigraphie der Mushgai Region verbessert werden, was in der Revision der stratigraphischen Reichweiten von Formationen/Member resultiert, so z.B. der Arynshand Formation, die von der späten Bispathodus ultimus Zone bis zur Scaliognathus anchoralis-Doliognathus latus Zone reicht.

- Im Hinblick auf die regionale Geologie legen wir eine verbesserte lithologische Beschreibung der Formationen vor und wir konnten darüber hinaus zeigen, dass submariner und/oder subaerischer Vulkanismus in beiden Profilen besonders während des späten Devon eine entscheidende Rolle gespielt hat, was die Hypothese unterstützt, dass der Vulkanismus wahrscheinlich ein wesentlicher Steuerungsfaktor für Spätdevonische Aussterbeereignisse war. 


\section{Quellenverzeichnis (References)}

Badarch, G., Cunningham, W.D., \& Windley, B.F. (2002). A new subdivision for Mongolia: implications for Phanerozoic crustal growth in Central Asia. Journal of Asian Earth Sciences, 21, $87-110$.

Crônier, C., Ariuntogos, M., Königshof, P., Waters, J., \& Carmichael, S. (2021). Late Devonian (Famennian) phacopid trilobites from western Mongolia. Palaeobiodiversity and Palaeoenvironments, 101(3). https://doi.org/10.1007/s12549-020-00449-w.

Crônier, C., Malti, F.Z., François, A., Benyoucef, M., \& Brice, D. (2013). First occurrence of a phacopid trilobite faunule from the Upper Devonian of Saoura Valley, Algeria and biodiversity fluctuations. Geological Magazine, $\quad 150, \quad$ 1002-1021. https://doi.org/10.1017/S0016756813000277.

Königshof, P., Bahrami, A., and Kaiser, S.I. (2021). Devonian/Carboniferous Boundary sections in Iran. In M. Aretz, \& C. Corradini, (Eds.), Global review of the Devonian-Carboniferous Boundary. Palaeobiodiversity and Palaeoenvironments, 101(2), 613-632. https://doi.org/10.007/s12549-020-0438-z

Kröner, A., Kovach, V., Belousova, E., Hegner, E., Armstrong, R., Dolgopolova, A., Seltmann, R., Alexeiev, D.V., Hoffmann, J.E., Wong, J., Sun, M., Cai, K., Wang, T., Tong, Y., \& Wilde, S.A. (2014). Reassessment of continental growth during the accretionary history of the Central Asian Orogenic Belt. Gondwana Research, 25, 103-125.

Moreno, C., Sierra, S., \& Saez, R. (1996). Evidence for catastrophism at the FamennianDinantian boundary in the Iberian Pyrite Belt. Geological Society London Special Publications, 107(1), 153-162. https://doi.org/10.1144/GSL.SP.1996.107.01.12

Munkhjargal, A., Königshof, P., Hartenfels, S., Jansen, U., Nazik, A., Carmichael, S.K., Waters, J.A., Sersmaa, G., Crônier, C., Ariunchimeg, Ya., Paschall, O., \& Dombrowski, A. (2021). The Hushoot Shiveetiin gol section (Baruunhuurai Terrane): Sedimentology and facies from a Late Devonian island arc setting. Palaeobiodiversity and Palaeoenvironments, 101(3). https://doi.org/10.1007/s12549-020-00445-0.

Munkhjargal, A., Königshof, P., Waters, J.A., Carmichael, S.K., Gonchigdorj, S., Thassanapak, H., Udchachon, M., and Sharav, D. (2021). The Mandalovoo-Gurvansayhan terranes in the Southern Gobi of Mongolia: new insights from the Bayankhoshuu Ruins section. Palaeobiodiversity and Palaeoenvironments, 101(3). https://doi.org/10.1007/s12549-020-00471$\mathrm{y}$

Nazik, A., Königshof, P., Ariuntogos, M., Waters, J.A., \& Carmichael, S.K. (2021). Late Devonian ostracods from the Hushoot Shiveetiin gol island arc section (Baruunhuurai Terrane, western Mongolia) and their palaeoenvironmental implication and palaeobiogeographic 
relationship. Palaeobiodiversity and Palaeoenvironments, 101(3). https://doi.org/10.1007/s12549-020-00446-z.

Paschall, O.C., Carmichael, S.K., Königshof, P., Waters, J.A., Ta, P.H., Komatsu, T., \& Dombrowski, A. (2019). The Hangenberg Event in Vietnam: sustained ocean anoxia with a volcanic trigger? Global and Planetary Change, 175, 64-81. https://doi.org/10.1016/j.gloplacha.2019.01.021.

Racki, G., Königshof, P., Bełka, Z., Dopieralska, J., \& Pisarzowska, A. (2019). Diverse geochemical signature of the Frasnian-Famennian global event in the western Thailand, as the record of Palaeotethyan vs. Western Australian geotectonic affinities. Journal of Asian Earth Sciences, 2. https://doi.org/10.1016/j.jaesx.2019.100010.

Racki, G., Rakociński, M., \& Marynowski, L. (2018). Anomalous Upper Devonian mercury enrichments: Comparison of inductively coupled plasma-mass spectrometry (ICPMS) and AAS analytical data. Geology Quarterly, 62(3), 487-495. https://doi.org/10.7306/gq.1419.

Raconski, M., Pisarzowska, A., Corradini, C., Narkiewicz, K., Dubicka, Z., \& Abdieyev, N. (2021). Mercury spikes as evidence of extended arc-volcanism around the DevonianCarboniferous boundary in the South Tian Shan (southern Uzbekistan). Scientific Reports, 11(1). https://doi.org/10.1038/s41598-021-85043-6.

Roelofs, B., Königshof, P., Trinajstic, K., \& Munkhjargal, A. (2021). Vertebrate microremains from the Late Devonian (Famennian) of western Mongolia. Palaeobiodiversity and Palaeoenvironments. https://doi.org/10.1007/s12549-021-00503-1.

Safonova, I., Kotlyarov, A., Krivonogov, S., \& Xiao, W. (2017). Intraoceanic arcs of the PaleoAsian Ocean. Gondwana Research, 50, 167-194. https://doi.org/10.1016/j.gr.2017.04.005.

Tolokonnikova, Z.A., \& Ernst, A. (2010). Palaeobiogeography of Famennian (Late Devonian) bryozoans. Palaeogeography Palaeoclimatology Palaeoecology, 298(3-4), 360-369.

Waters, J.A., Maples, C.G., Lane, N.G., Marcus, Liao, S.Z., Liu, L., Hou, H.F., \& Wang, J.X. (2003). A quadrupling of Famennian pelmatozoan diversity: New Late Devonian blastoids and crinoids from Northwest China. Journal of Paleontology, 77, 922-948.

Waters, J.A., Waters, J.W., Königshof, P., Carmichael, S., \& Ariuntogos, M. (2021). Famennian Crinoids and Blastoids (Echinodermata) from Mongolia. Palaeobiodiversity and Palaeoenvironments, 101(3). https://doi.org/10.1007/s12549-020-00450-3.

Waters, J.A., \& Webster, G.D. (2009). A re-evaluation of Famennian echinoderm diversity: Implications for patterns of extinction and rebound in the Late Devonian. Geological Society London Special Publications, 314(1), 149-161. 
Windley, B.F., Alexeiev, D., Xiao, W., Kröner, A., \& Badarch, G. (2007). Tectonic models for accretion of the Central Asian Orogenic Belt. Journal of the Geological Society, 164, 31-47. https://doi.org/10.1144/0016-76492006-022.

Xiao, W.J., Huang, B.C., Han, C.M., Sun, S., \& Li, J.L. (2010). A review of the western part of the Altaids: A key to understanding the architecture of accretionary orogens. Gondwana Research, 18(2-3), 253-273. https://doi.org/10.1016/j.gr.2010.01.007.

Xiao, W., \& Santosh, M. (2014). The western Central Asian orogenic belt: A window to accretionary orogenesis and continental growth. Gondwana Research, 25(4), 1429-1444. https://doi.org/10.1016/j.gr.2014.01.008.

Yang, G., Li, Y., Tong, L., Wang, Z., Duan, F., Xu, Q., \& Li, H. (2019). An overview of oceanic island basalts in accretionary complexes and seamounts accretion in the western Central Asian orogenic belt. Journal of Asian Earth Sciences, 179, 385-398. https://doi.org/10.1016/j.jseaes.2019.04.011. 